MARIA DO SOCORRO DA SILVA

\title{
Ações afirmativas para a população negra: um instrumento para a justiça social no Brasil
}

\author{
Dissertação de Mestrado apresentada à \\ Área de Concentração em Direitos Humanos da \\ Faculdade de Direito da Universidade de São Paulo
}

Orientador: Prof. Dr. Kabengele Munanga

Universidade de São Paulo

São Paulo

2009 
MARIA DO SOCORRO DA SILVA

\title{
Ações afirmativas para a população negra: um instrumento para a justiça social no Brasil
}

\author{
Dissertação de Mestrado apresentada à \\ Área de Concentração em Direitos Humanos da \\ Faculdade de Direito da Universidade de São Paulo
}

Banca Examinadora:

Prof. Dr. Kabengele Munanga - USP - orientador 
Agradecimentos

Ao meu orientador, Prof. Dr. Kabengele Munanga, pela preciosa orientação e estímulo; Ao meu marido, Mário Baldini, pela contribuição e apoio;

Aos meus pais, Maria do Carmo de Oliveira e Ernando Braga da Silva. 


\section{RESUMO}

No presente trabalho nós pretendemos discutir e analisar o alcance da política de ações afirmativas no combate às desigualdades raciais, decorrentes das práticas racistas no Brasil. Partimos da hipótese de que, uma vez diminuídas as desigualdades raciais, haverá promoção da justiça social pois os recursos serão distribuídos objetivando maior equidade. Desta feita, as ações afirmativas para a população negra constituem-se em instrumento para a Justiça Social. A desigualdade racial é uma violação ao direito humano à igualdade, e a relação das ações afirmativas com os Direitos Humanos refere-se tanto ao direito à igualdade como ao direito à diferença, pois os negros representam um grupo social vulnerável na sociedade. As ações afirmativas para a população negra justificam-se pelas perdas históricas acumuladas, perdas que as tradicionais políticas macro-sociais ou universalistas não seriam capazes de minimizar. Relevantes estudos e pesquisas realizados em ciências sociais nas décadas de 50 e 70 e as pesquisas estatísticas recentes não deixam dúvida sobre as gritantes desigualdades raciais entre brancos e negros, contrariando a propalada democracia racial. Há quem defenda que as ações afirmativas são inconstitucionais, por ferirem o princípio da igualdade de todos perante a lei, porém é a própria Constituição que impulsiona a busca pela igualdade material, em vários dos seus artigos, o que justifica as ações afirmativas. A partir de 2001 começaram a ser implementadas políticas de cotas para negros nas universidades públicas, o que causou grandes polêmicas e debates acalorados que persistem até hoje. Para uma melhor compreensão das políticas de ações afirmativas como forma de justiça social, serão examinados primeiramente seus antecedentes históricos e alguns conceitos-chave. Posteriormente, aspectos da teoria de justiça social de John Rawls serão criticamente analisados para aclarar o conceito de justiça social. Por fim, através de um levantamento de experiências de ações afirmativas em diversas Instituições Públicas de Ensino Superior (IPES), poderemos observar a prática dessa justiça social voltada para a população negra. Conclui-se que as ações afirmativas oferecem uma alternativa válida no processo de promoção da justiça social em benefício desse segmento da população brasileira historicamente injustiçado.

Palavras-chave: ações afirmativas, negros, justiça social, igualdade, desigualdade racial 


\begin{abstract}
In this study we intend to discuss and examine the scope of the policy of affirmative action to combat racial inequalities, arising from racist practices in Brazil. Starting from the assumption that, once reduced racial inequalities, it will promote social justice because the resources will be distributed seeking greater fairness. This time, the affirmative action for the black population is itself an instrument for Social Justice. The racial inequality is a violation of the human right to equality and affirmative action with respect of Human Rights refers to both the right to equality and the right to difference, because the blacks are a social vulnerable group in society. The affirmative action for the black population is justified by historical accumulated losses, losses that the traditional macro-social or universalist policies would not be able to minimize. Relevant studies and research in social sciences in the decades of 50 and 70 and the recent statistics studies leave no doubt on the blatant racial inequalities between blacks and whites, contrary to disclosed racial democracy. Some argue that affirmative action is unconstitutional, injure by the principle of equality of all before the law, but is the Constitution itself that drives the quest for equality material in several of its articles, which justified the affirmative action. From 2001 began to be implemented policy of quotas for blacks in public universities, which caused great controversy and heated debates that persist today. For a better understanding of the policies of affirmative action as a form of social justice, will be first examined its historical background and some key concepts. Subsequently, aspects of the theory of social justice of John Rawls will be critically examined to clarify the concept of social justice. Finally, through a survey of experiences of various affirmative actions in Public Institutions of Higher Education (IPES), we can observe the practice of social justice toward the black population. It was concluded that affirmative action offers a viable alternative in the process of promoting social justice for the benefit of that segment of the population historically wronged.
\end{abstract}

Keywords: affirmative action, blacks, social justice, equality, racial inequality 


\section{SUMÁRIO}

Introdução

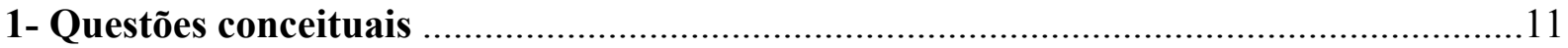

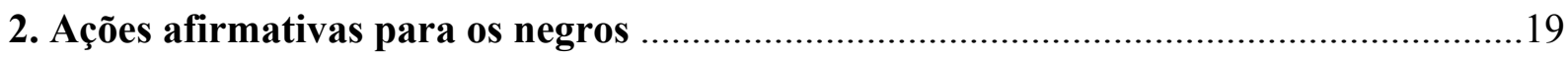

2.1. Por que ações afirmativas para negros? .......................................................................19

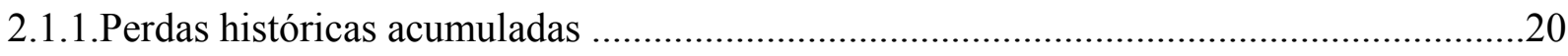

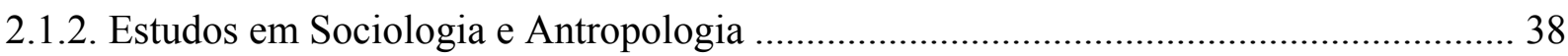

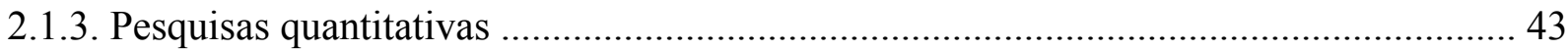

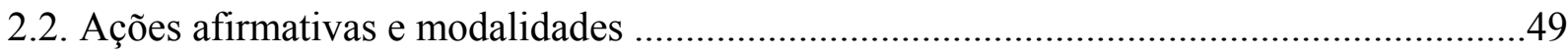

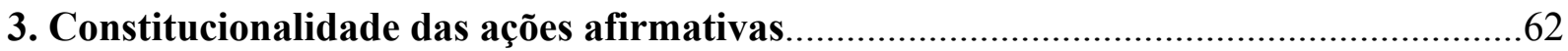

3.1. Conteúdo jurídico do princípio da igualdade ...................................................................70

3.2. Limites para as ações afirmativas ...............................................................................73

4. Propostas de implementação das políticas de ação afirmativa para população negra no

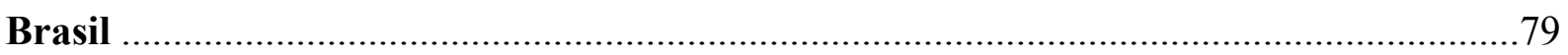

4.1. Trezentos anos da morte de Zumbi de Palmares e a Marcha do Movimento Negro de

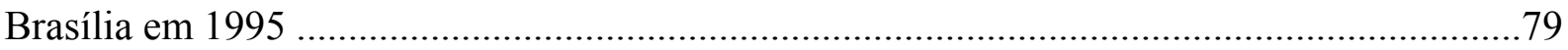

4.2. Seminário Internacional "Multiculturalismo e Racismo: o papel da ação afirmativa nos estados democráticos contemporâneos"

4.3. Conferência Mundial de Combate ao Racismo, Discriminação Racial, Xenofobia e

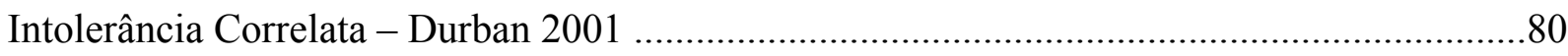

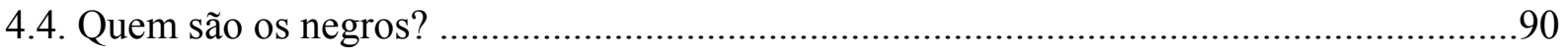

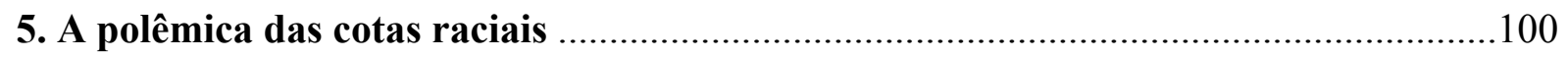

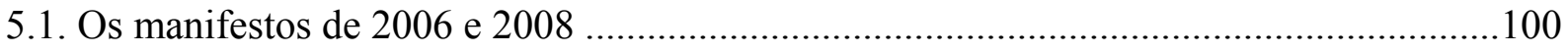

5.2. Argumentos contra as cotas raciais e a favor das cotas raciais nas Instituições Públicas de

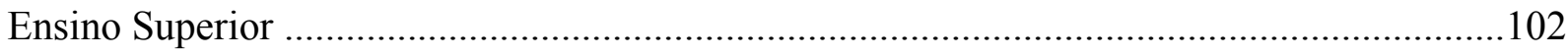


5.3. Argumentos a favor das cotas conforme José Jorge de Carvalho e conforme divulgado

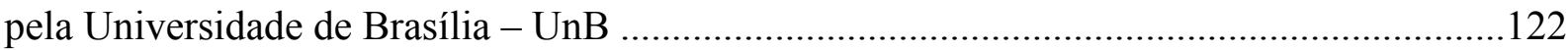

5.4. Aprovação na Câmara Federal do Projeto de lei no 73/1999 em 20/11/2008 .................123

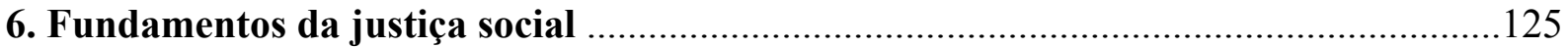

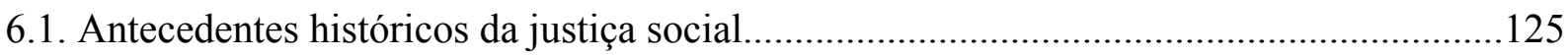

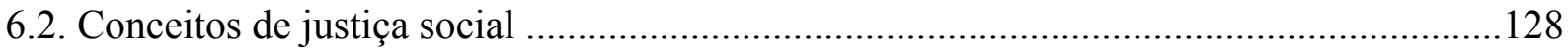

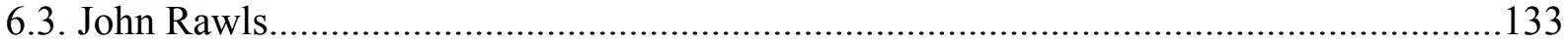

6.4. Justiça social e a Constituição Federal ......................................................................145

7. Experiências das ações afirmativas em universidades públicas brasileiras - 2008.....153

7.1. Relação das ações afirmativas em Instituições Públicas de Ensino Superior (IPES)

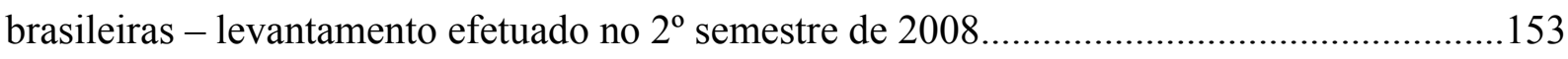

7.2. Comentários sobre as ações afirmativas nas IPES ..................................................178

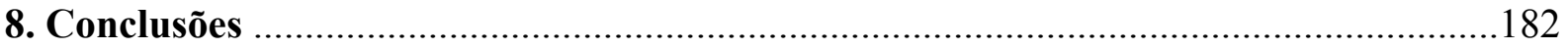

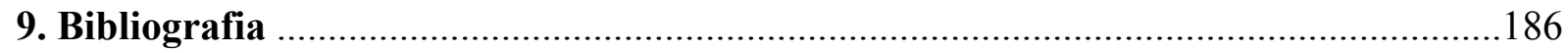

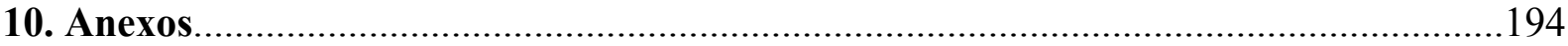

Anexo 1: "Todos têm direitos iguais na República" ............................................................195

Anexo 2: "Manifesto em favor da lei de cotas e do estatuto da igualdade racial" ................197

Anexo 3: "Cidadãos Anti-racistas contra as leis raciais" ..................................................201

Anexo 4: "Manifesto em defesa da justiça e constitucionalidade das cotas" .......................208 


\section{Introdução}

A questão central desta dissertação é analisar e discutir a utilização de ações afirmativas para a população negra, como forma de diminuir as desigualdades raciais, as quais, de acordo com os indicadores sócio-econômicos desfavorecem a população negra. Partimos da idéia de que a diminuição das desigualdades raciais servirá para promover a justiça social, logo, as ações afirmativas servem como um dos instrumentos apropriados.

Conforme a Constituição Federal do Brasil, a Ordem Econômica deve guiar-se pelos ditames da justiça social (art. 170) e a Ordem Social tem como objetivo a justiça social (art. 193). Verifica-se por essas diretrizes, a preocupação do constituinte com a realização da justiça social no Brasil. Para tal, políticas são necessárias e vários instrumentos podem servir para tal finalidade. Como é objetivo da justiça social a diminuição das desigualdades sociais e econômicas, sob o primado da dignidade da pessoa humana, para sua efetivação torna-se necessário identificar os grupos vulneráveis na sociedade, vítimas da desigualdade e injustiça social, e promover políticas que promovam mais igualdade e eqüidade. As ações afirmativas constituem-se numa dessas políticas e a população negra constitui-se num grupo vulnerável.

Numa abordagem histórica da evolução ética da humanidade, vemos que os conceitos e os princípios de igualdade e eqüidade evoluem no sentido de alcançar uma plena dignidade humana, e as ações afirmativas, sendo um dos instrumentos para a justiça social, encaixam-se plenamente nessa luta universal dos povos para a redução das desigualdades sócio-econômicas e raciais.

A presente dissertação se justifica pois as desigualdades raciais que a população negra sofre correspondem a um gravíssimo problema de Direitos Humanos e de justiça social. Devido à desigualdade racial os Direitos Humanos dos negros no Brasil são sistematicamente desrespeitados. Não combater a pobreza de maneira eficaz e eficiente é flagrante violação da dignidade humana e contraria a Justiça Social almejada pela Constituição. A pobreza atinge todos os brasileiros, mas entre os pobres, os negros são os mais pobres por causa da discriminação racial. Conforme Paixão: 
É um fato que a pobreza no Brasil tem cor: negra. Tal afirmação não pode ocultar a existência de um amplo contingente de pessoas pobres e extremamente pobres que não são negras. Todavia, a maioria dos negros não é negra porque é pobre, mas, sim, é pobre (ou mais pobre), justamente por ser negra. Assim, sem deixar de reconhecer os pobres de diferentes cores ou raças e as pessoas negras de maior poder aquisitivo, o fato é que os motivos de sua existência não são exatamente os mesmos. No caso dos negros, a principal causa da pobreza vem a ser a persistência do preconceito, da discriminação racial e do racismo. Tais mazelas, certamente, se associam à discriminação social, que, entretanto, não as esgota e nem as resume ${ }^{1}$

A desigualdade racial persiste ao longo dos anos. Estudo do IPEA mostra que diferença de renda entre negros e brancos não se altera há 25 anos, ou seja, no espaço de pelo menos uma geração, a diferença de renda entre os dois grupos permaneceu inalterada. Em 1976, as pessoas que se declararam pretas ou pardas eram 39,5\% da população do Brasil e 57,6\% da parcela mais pobre; em 2001, os negros eram $46,1 \%$ da população e $69,6 \%$ dos mais pobres. Os dados fazem parte de um levantamento realizado pelo sociólogo Rafael Guerreiro Osório, hoje no Centro Internacional de Pobreza, do PNUD. Conforme Osório: “quem nasceu em 1976 e entrou no mercado de trabalho em 2001, por exemplo, encontrou relativamente a mesma situação que os pais enfrentavam 25 anos antes". 2

Osório usou os dados de quatro edições da PNAD (Pesquisa Nacional por Amostra de Domicílios): 1976, 1986, 1996 e 2001. Ele dividiu a população brasileira em 20 faixas iguais, de acordo com a renda - de maneira que cada parcela agrupa $5 \%$ da população, dos $5 \%$ mais pobres até os $5 \%$ mais ricos. Em cada uma dessas faixas, verificou se a proporção de negros era maior ou menor do que em toda a população. O resultado demonstrou que, quanto menor é a faixa de renda, maior é a proporção de negros - e que essa situação alterou-se muito pouco nos últimos 25 anos. ${ }^{3}$

Frente a esse quadro percebemos que políticas macro-sociais ou universalistas não resolveram o problema da desigualdade racial, logo, políticas focais são necessárias, como as ações afirmativas. Conforme Osório: "Nesses últimos 25 anos o acesso a educação melhorou, a pobreza diminuiu, pelo menos segundo alguns autores, mas a distância entre brancos e negros não se alterou". 4

Dessa forma, os objetivos do presente trabalho são:

\footnotetext{
${ }^{1}$ PAIXÃO, Marcelo, CARVANO, Luiz M. (orgs). Relatório Anual das Desigualdades Raciais no Brasil; 2007-2008. Rio de Janeiro: Garamond, 2008, p. 18.

${ }^{2}$ PNUD, PROGRAMA DAS NAÇÕES UNIDAS PARA O DESENVOLVIMENTO. "Fosso entre negros e brancos não se altera há 25 anos”. Brasília, 04/02/2005. Consulta na internet, endereço

http://www.pnud.org.br/noticias/impressao.php?id01=975, acesso em 10-01-2009.

${ }^{3}$ Idem.

${ }^{4}$ Ibdem.
} 
- focalizar a população negra, grupo vitimizado pelas desigualdades raciais que vem de longa data;

- estudar essas desigualdades raciais e as ações afirmativas como forma de mitigar tais desigualdades;

- exemplificar algumas modalidades de ação afirmativa que estão sendo feitas, dando ênfase à polêmica das cotas;

- apontar parâmetros sobre justiça social;

- levantar dados sobre ações afirmativas que estão sendo praticadas nas Instituições Públicas de Ensino Superior, a fim de verificar exemplos de ações afirmativas para a população negra no Brasil.

A hipótese é que havendo prática de ações afirmativas para a população negra, estaremos promovendo mais igualdade, logo, mais justiça social.

A metodologia do trabalho consistiu em pesquisa bibliográfica especializada, com análise do discurso e do conteúdo, discussão dos princípios envolvidos nos textos e posterior síntese e conclusão. Além da bibliografia específica do tema, foram pesquisadas revistas e periódicos, artigos de internet, bases de dados eletrônicos e levantamentos estatísticos.. Foi feita pesquisa na internet em sites das Instituições Públicas de Ensino Superior, para acompanhar a prática de ações afirmativas. 


\section{Questões conceituais}

\section{Direitos Humanos, ações afirmativas e igualdade}

As desigualdades raciais sofridas pela população negra, observáveis em dados estatísticos de órgãos governamentais como IPEA e IBGE, mostram que o direito humano à igualdade dos negros está sendo violado, e com este, também outros direitos, pois à medida que a população negra sofre preconceito e discriminação racial no acesso ao trabalho, à saúde, à educação, esses direitos humanos são desrespeitados. Além da discriminação explícita, existe a discriminação implícita, que atua no cotidiano das instituições, no seu funcionamento e organização, de maneira difusa, não punível por lei, mas eficaz na hierarquização racial em detrimento da população negra (racismo institucional). Temos, dessa maneira, a existência de discriminação racial no presente e as perdas acumuladas historicamente, graças à escravidão, à ausência de políticas públicas no período pós-abolição e ideologias desvalorizadoras da identidade negra, como a tese do branqueamento e da democracia racial. Esses fatores contribuem para a desigualdade racial e conseqüente violação do direito à igualdade da população negra.

Uma forma de combater as desigualdades raciais são as ações afirmativas, também conhecidas como discriminação positiva, que consistem em políticas compensatórias e de inclusão dos grupos desfavorecidos, produzindo mais igualdade. Podemos dizer, portanto, que as ações afirmativas são uma questão de Direitos Humanos, pois contribuem para sua promoção.

A fim de definir o que são Direitos Humanos, recorremos a Comparato e a Bobbio. Para Comparato os Direitos Humanos são aqueles cujo fundamento é o próprio homem, "considerado em sua dignidade substancial de pessoa, diante da qual as especificações individuais e grupais são sempre secundárias" ${ }^{\prime 5}$. Quanto à dignidade, para Comparato:

5 COMPARATO, Fábio Konder. "Fundamento dos Direitos Humanos". In: MARCílIO, Maria Luiza e PUSSOLI, Lafaiete (coord.). Cultura dos direitos humanos. São Paulo: LTr, p. 60, 1998. 
Para definir a especificidade ontológica do ser humano, sobre a qual fundar a sua dignidade no mundo, a antropologia filosófica hodierna vai aos poucos estabelecendo um largo consenso sobre algumas características próprias do homem, a saber, a liberdade como fonte da vida ética, a autoconsciência, a sociabilidade, a historicidade e a unicidade existencial do ser humano. ${ }^{6}$

Segundo o autor, a liberdade refere-se à vontade do ser humano, sua capacidade de agir livremente sem o determinismo dos instintos. É nesse fundamento que se assenta as preferências valorativas e a ética, a capacidade do homem de ditar suas próprias normas de conduta. A autoconsciência humana refere-se à consciência de sua própria subjetividade, consciência de ser vivente e mortal. O homem é um animal reflexivo, capaz de se enxergar como sujeito o mundo. A sociabilidade foi enfatizada por Aristóteles, o qual afirma que a pólis é anterior ao indivíduo. O pensamento moderno rejeita essa concepção, que conduz a supremacia ética da sociedade em relação ao indivíduo, razão justificadora dos mais bestiais totalitarismos. O que se deve reconhecer é que o homem só desenvolve suas virtualidades de pessoa em sociedade, qualidades próprias do ser humano, como a razão, a capacidade de criação estética, o amor, são essencialmente comunicativas. A historicidade nos diz que o homem vive em perpétua transformação, pela memória do passado e o projeto do futuro. O ser humano deixa rastros na sua trajetória, acumulando invenções culturais de todo gênero e modificando a si próprio. Assim que o homem contemporâneo em sua essência é diferente do homem da Idade Média, do Renascimento ou do Século das Luzes. A unicidade existencial nos diz que cada ser humano é único e insubstituível no mundo. Desta feita:

Esse conjunto de características diferenciais do ser humano demonstra, como assinalou Kant, que todo homem tem dignidade e não um preço, como as coisas. $\mathrm{O}$ homem como espécie, e cada homem em sua individualidade, é propriamente insubstituível: não tem equivalente, não pode ser trocado por coisa alguma. Mais ainda: o homem é não só o único ser capaz de orientar suas ações em função de finalidades racionalmente percebidas e livremente desejadas, como é sobretudo, o único ser cuja existência, em si mesma, constitui um valor absoluto, isto é, um fim em si e nunca um meio para a consecução de outros fins. É nisto que reside, em última análise, a dignidade humana. $^{7}$

Por sua vez, sem aceitar um fundamento absoluto para os Direitos Humanos e considerando tautológicas definições como "Direitos do homem são os que cabem ao homem enquanto homem", , Norberto Bobbio alerta para a ilusão do fundamento absoluto:

\footnotetext{
${ }^{6}$ Ibdem, p. 69.

${ }^{7}$ Ibdem, p. $72-73$

${ }^{8}$ BOBBIO, Norberto. A Era dos Direitos. Rio de Janeiro: Campus, 2004, p.37.
} 
Essa ilusão foi comum durante séculos aos jusnaturalistas, que supunham ter colocado certos direitos acima da possibilidade de qualquer refutação, derivando-os diretamente da natureza do homem. Mas a natureza do homem revelou-se muito frágil como fundamento absoluto de direitos irresistíveis. (...) Para dar um exemplo: ardeu por muito tempo entre os jusnaturalistas a disputa acerca de qual das três soluções possíveis quanto à sucessão de bens (o retorno à comunidade, a transmissão familiar de pai para filho ou a livre disposição pelo proprietário) era a mais natural e, portanto, devia ser preferida num sistema que aceitava como justo tudo o que se fundava na natureza. Podiam disputar por muito tempo: com efeito, todas as três soluções são perfeitamente compatíveis com a natureza do homem, conforme se considere este último como membro de uma comunidade (da qual, em última instância, sua vida depende), como pai de família (voltado por instinto natural para a continuação da espécie) ou como pessoa livre e autônoma (única responsável pelas próprias ações e pelos próprios bens). ${ }^{9}$

Bobbio, ao identificar esta crise na fundamentação dos Direitos Humanos, passa a buscar o "fundamento possível", em substituição ao fundamento absoluto. Percebe que os Direitos Humanos não podem ser dissociados do estudo dos problemas históricos, sociais, econômicos e psicológicos inerentes à sua realização. Bobbio passa a fundamentar os Direitos Humanos no fato de que, em um dado período histórico, tais direitos são geralmente aceitos, ou seja, haveria um consenso acerca da sua aceitabilidade. Da busca por um fundamento absoluto, passa-se para um fundamento histórico, do consenso, obviamente não absoluto, mas objetivo. Os antigos jusnaturalistas desconfiavam dos fundamentos históricos, dada a dificuldade de comprovar o consenso. Para Bobbio essa comprovação agora existe, trata-se de um documento: a Declaração Universal dos Direitos Humanos, aprovada por 48 Estados, em 10 de dezembro de 1948, na Assembléia Geral das Nações Unidas.

Os Direitos Humanos são históricos, pois surgem no decorrer da História e não podemos considerar que sua lista esteja esgotada. Assim, falamos em Direitos Humanos de $1^{a}$ geração, de $2^{\mathrm{a}}$ geração, de $3^{\mathrm{a}}$ geração e até de uma $4^{\mathrm{a}}$ geração, em função de seus surgimentos na História.

Piovesan partilha da visão de Bobbio e cita Hannah Arendt, a qual diz que os direitos humanos não são um dado, mas um construído, uma invenção humana, em constante processo de construção e reconstrução ${ }^{10}$. Piovesan completa dizendo que esse construído é axiológico, a

\footnotetext{
${ }^{9}$ Idem, p. 36.

${ }^{10}$ ARENDT, Hannah. Apud PIOVESAN, Flávia. "Ações afirmativas sob a perspectiva dos direitos humanos". In: DUARTE, Evandro C. Piza, BERTúliO, Dora Lúcia de Lima e SILVA, Paulo Vinícius Baptista da (coords.). Cotas raciais no ensino superior. Curitiba: Juruá Editora, 2008, p. 16.
} 
partir de um espaço simbólico de luta e de ação social. ${ }^{11}$ Conforme a autora, as violações também são um construído e como tais devem ser desconstruídas através de medidas eficazes:

se os direitos humanos não são um dado, mas um construído, enfatiza-se agora que as violações a estes princípios também o são. Isto é, as violações, as exclusões, as discriminações, a intolerância, o racismo, as injustiças raciais são um construído histórico, a ser urgentemente desconstruído, sendo urgente, portanto, a adoção de medidas eficazes para romper com o legado de exclusão étnicoracial. Há que se enfrentar essas amarras, mutiladoras do protagonismo, da cidadania e da dignidade dessa população discriminada historicamente. ${ }^{12}$

As medidas eficazes para romper com o legado de exclusão étnico-racial citadas pela autora conformam-se perfeitamente com a adoção de ações afirmativas para a população negra.

Piovesan questiona de que modo poderão ser formuladas ações afirmativas, guardando a perspectiva do respeito aos Direitos Humanos. Para a autora, ao lado do direito à igualdade, surge como axioma fundamental o direito à diferença. ${ }^{13}$ Piovesan destaca três vertentes no que tange à concepção da igualdade:

. A igualdade formal, reduzida à fórmula 'todos são iguais perante a lei' (que, ao seu tempo, foi crucial para a abolição de privilégios);

. A igualdade material, correspondente ao ideal de justiça social e distributiva (igualdade orientada pelo critério socioeconômico);

- Por fim, a igualdade material, correspondente ao ideal de justiça, como um fator de reconhecimento de identidades (igualdade orientada pelos critérios: gênero, orientação sexual, idade, raça, etnia e demais critérios). ${ }^{14}$

Logo, cumpre ressaltar, que tão importante quanto o direito à igualdade, é o direito à diferença. Ser diferente não significa ser desigual, a desigualdade entendida como hierarquização. $\mathrm{O}$ direito à diferença implica no reconhecimento da identidade, a qual baseiase em critérios como gênero, orientação sexual, idade, raça, etnia e demais critérios. É o reconhecimento da diferença que permite o reconhecimento de grupos vulneráveis, passíveis de especificação dos sujeitos titulares de direitos. É assim que surgem, por exemplo, a Declaração de Direitos da criança (1959), a Declaração sobre a Eliminação da Discriminação à

\footnotetext{
${ }_{11}^{11}$ PIOVESAN, Flávia. Op. cit., p. 16.

${ }^{12}$ idem, p. 26.

${ }^{13}$ Ibdem, p. 18 .

${ }^{14}$ Ibdem, p. 18-19.
} 
Mulher (1967), a Declaração dos Direitos do Deficiente Mental (1971). Nesse quadro de reconhecimento do direito à igualdade e do direito à diferença os Direitos Humanos se coadunam com as ações afirmativas. Por um lado busca-se mais igualdade pela política de ação afirmativa, por outro, reconhecendo-se as diferenças, as identidades, encontramos o público-alvo da ação afirmativa.

\section{Conforme Boaventura de Sousa Santos:}

as pessoas e os grupos sociais têm o direito a ser iguais quando a diferença os inferioriza, e o direito a ser diferentes quando a igualdade os descaracteriza. ${ }^{15}$

Falamos de igualdade, mas o que significa a igualdade? Menezes a define da seguinte maneira:

Conceito comparativo que busca estabelecer um equilíbrio entre os membros da sociedade, de forma a assegurar, mesmo que indireta e parcialmente, a efetivação do ideal de justiça. Ainda que com conteúdo e alcance distintos, a igualdade encontra-se prevista em grande parte das Constituições contemporâneas, notadamente como princípio jurídico. ${ }^{16}$

Quando nos referimos à igualdade no campo político, ela é melhor explicitada quando especificamos entre quem e no que queremos igualdade. Conforme Bobbio:

(...) dizer que dois entes são iguais sem nenhuma outra determinação nada significa na linguagem política; é preciso que se especifique com que entes estamos tratando e com relação a que são iguais, ou seja, é preciso responder a duas perguntas: a) igualdade entre quem?; e b) igualdade em quê? $^{17}$

A igualdade é certamente um dos direitos que mais se destaca, um dos mais proclamados e requisitados, estando presente nas principais declarações de direitos. Vejamos alguns exemplos:

A Declaração de Virgínia, de 12/06/1776, estabelece:

15 SANTOS, Boaventura de Sousa e NUNES, João Arriscado. "Introdução: para ampliar o cânone do reconhecimento, da diferença e da igualdade". In: SANTOS, Boaventura de Sousa (org.). Reconhecer para libertar: os caminhos do cosmopolitismo multicultural. Rio de Janeiro: Civilização Brasileira, 2003 , p. 56.

${ }^{16}$ MENEZES, Paulo Lucena. In: DIMOLIOUS, Dimitri (coordenador geral) Dicionário Brasileiro de Direito Constitucional. São Paulo: Saraiva, 2007, p. 175

${ }^{17}$ BOBBIO, Norberto. Igualdade e Liberdade. Rio de Janeiro: Ediouro, 1997, p. 11 e 12. 
"Artigo 1: Todos os seres humanos são, pela sua natureza, igualmente livres $e$ independentes (...)"

Na Declaração de Independência dos Estados Unidos da América, de 04/07/1776, afirma-se:

“(...) Consideramos as seguintes verdades como auto-evidentes, a saber, que todos os homens são criaturas iguais, dotadas pelo seu Criador de certos direitos inalienáveis, entre os quais a vida, a liberdade e a busca da felicidade (...)”

A Declaração dos Direitos do Homem e do Cidadão de 1789, estipula:

"Artigo Primeiro: Os homens nascem e permanecem livres e iguais em direitos. As distinções sociais só podem fundar-se na utilidade comum."

Na Declaração Universal dos Direitos Humanos de 1948, lê-se:

"Artigo I : Todos os homens nascem livres e iguais em dignidade e direitos. São dotados de razão e consciência e devem agir em relação uns aos outros com espirito de fraternidade."

No entanto, observando a questão da igualdade no decorrer da História, vemos que os ideais não se coadunam com a realidade. $\mathrm{Na}$ Grécia, por exemplo, prevalecia na época de Aristóteles (séc. IV a. C.), uma grande desigualdade entre cidadãos gregos, que tinham uma posição privilegiada, e os estrangeiros, mulheres e escravos. O próprio Aristóteles escreveu textos tentando justificar a escravidão, apesar da sua grande influência nos temas sobre justiça e igualdade.

Quanto ao Cristianismo propagado pelo apóstolo Paulo, todos eram igualmente filhos de Deus: pobres, ricos, virtuosos, bandidos, povos de todo mundo, todos tinham em comum a filiação divina - tratava-se do universalismo evangélico. Mas essa igualdade dos filhos de Deus só valeu no plano sobrenatural, pois o Cristianismo admitiu a escravidão, a inferioridade da mulher e dos povos colonizados.

A Idade Antiga conviveu com o escravismo e a Idade Média conviveu com o feudalismo, onde a sociedade era dividida em estamentos: suseranos e vassalos, os primeiros 
donos da terra e em posição econômico-social superior aos vassalos. Ao feudalismo seguiu o capitalismo, que continuou produzindo uma sociedade extremamente desigual, a miséria convivendo com enormes fortunas nas mãos de poucos.

Nas colônias americanas, a partir de do séc. XVI, índios nativos e negros trazidos da África foram escravizados. Em meados do séc. XVI chegaram ao Brasil os primeiros navios transportando escravos da África. A Declaração de Virgínia, de 12/06/1776 e a de Independência dos Estados Unidos da América, de 04/07/1776, estipulavam que todos os homens eram iguais, mas a escravidão era permitida.

"Liberdade, igualdade e fraternidade", esse era o lema da Revolução Francesa de 1889. Enquanto as Declarações Americanas estavam preocupadas em firmar sua soberania, a Revolução Francesa pretendia-se universal. Nos debates da Assembléia Nacional Francesa sobre a Declaração de Direitos do Homem e do Cidadão, Mathieu de Montmorency repetiu em 8 de agosto:

os direitos do homem em sociedade são eternos, (...) invariáveis como a justiça, eternos como a razão; eles são de todos os tempos e de todos os países. ${ }^{18}$

Apesar do lema da Revolução, que previa a igualdade, e da pretensão igualitária e universal da Declaração, as mulheres francesas continuaram inferiores aos homens e sem direito ao voto. Tão pouco a escravidão das colônias francesas foi abolida. As mulheres só puderam votar a partir de 1893, na Nova Zelândia, primeiro país a conceder o voto feminino. As colônias francesas da África, como Argélia e outras, tiveram que recorrer à luta armada para se libertar do colonialismo francês. No Brasil, as mulheres adquiriram o direito ao voto em 1932, no governo Getúlio Vargas.

A Declaração Universal dos Direitos Humanos de 1948 surgiu após a II Guerra Mundial, onde o totalitarismo e a intolerância foram praticados. A Declaração representou um avanço para os Direitos Humanos, pois muitos países formalizaram esses direitos em suas

\footnotetext{
${ }^{18}$ COMPARATO, Fábio Konder. A afirmação histórica dos direitos humanos. São Paulo: Saraiva, p.130,
} 2005. 
Constituições, e ela inspirou diversos tratados. A Declaração afirma no seu artigo $1^{\circ}$ que todos os homens nascem livres e iguais em dignidade e direitos. No entanto, vivemos num sistema econômico excludente, onde as desigualdades imperam, dentro dos países e entre os países. Mas a igualdade continua um ideal a ser almejado e a luta contra as desigualdades é imperativa. Grupos excluídos social e economicamente devem ter sua situação melhorada e para tanto políticas devem ser praticadas. Instrumentos que possibilitem a inclusão desses grupos, como as ações afirmativas, são necessários e contribuirão para a justiça social, temas que aprofundaremos mais adiante, enfocando como grupo excluído a população negra. 


\section{Ações afirmativas para os negros}

\subsection{Por que ações afirmativas para negros?}

As tradicionais políticas sociais universalistas, e as leis antidiscriminatórias, não alcançaram o objetivo de diminuir as desigualdades raciais, como vimos nos dados levantados por Osório, na introdução do presente trabalho. Conforme Paixão \& Carvano:

I) Foram os negros de ambos os sexos os mais prejudicados pelo caráter restrito e insuficiente das políticas sociais ao longo da história brasileira;

II) A exclusão de um contingente proporcionalmente maior de negros na definição das políticas sociais não foi produzida espontaneamente, mas, sim motivada por um entranhado racismo institucional que considerava indesejável a presença afro-descendente na sociedade;

III) a aplicação momentânea de recursos relativamente mais concentrada em um determinado contingente da população historicamente discriminado não necessariamente se contrapõe à perspectiva de universalização dos serviços sociais e a progressiva melhoria dos indicadores sociais em geral. ${ }^{19}$

Observa-se, portanto, que as políticas universalistas não são incompatíveis com as políticas focalizadas, as primeiras podem e devem ser utilizadas juntamente com as políticas focalizadas. Para reduzir as desigualdades raciais, é necessário inovar, adotando políticas de ação afirmativa. Conforme Paixão \& Carvano:

Por outro lado, quando se propõe a adoção de políticas de ação afirmativa, o eixo central do debate se situa na superação da discriminação racial, geradora das assimetrias entre brancos e negros. Assim, a universalização dos serviços públicos, embora fundamental, não seria capaz de lidar com o motor dinâmico que gera as assimetrias raciais que é o racismo. Desse modo, na ausência de ações efetivas para o enfrentamento dessa última questão e seus efeitos deletérios, as disparidades nas condições de vida entre os distintos contingentes de cor ou raça se prorrogarão indefinidamente. ${ }^{20}$

As atuais desigualdades raciais têm suas explicações. A primeira delas refere-se a perdas históricas acumuladas. Podemos considerar como perdas históricas acumuladas para a população negra, os acontecimentos que prejudicaram os negros, sendo que seus efeitos ainda repercutem. A escravidão no Brasil foi uma gravíssima e ignóbil violação dos direitos humanos à igualdade e liberdade da população negra, e seus efeitos repercutem, porque após a

\footnotetext{
${ }^{19}$ PAIXAO, Marcelo, CARVANO, Luiz M. , (orgs.), Relatório Anual das Desigualdades Raciais no Brasil; 2007-2008. Rio de Janeiro: Garamond, 2008,p.19.

${ }^{20}$ Idem, p. 19.
} 
abolição da escravidão a igualdade de fato entre brancos e negros não foi alcançada. Eles não tiveram nenhum auxílio do Estado, enquanto este financiava a imigração. As ideologias que floresceram nas primeiras décadas após a abolição, como a tese do branqueamento e a democracia racial, perpetram seus efeitos nefastos no ideário da população até os dias de hoje, tornando-se na prática uma barreira para excluir ou impedir o acesso da população negra a bens e posições na sociedade, diminuindo ou mesmo eliminando suas oportunidades. A segunda razão refere-se à discriminação racial persistente, através de um racismo que se renova, como forma de excluir um grupo (os negros) da competição por bens da sociedade. Esse fato é demonstrável pelas pesquisas de campo e estatísticas, desde os estudos em Sociologia e Antropologia das décadas de 50 e 70 até os estudos atuais, onde se observa que as disparidades entre brancos e negros continuam.

Nos tópicos a seguir veremos em detalhes os temas acima levantados, iniciando pelas perdas históricas acumuladas, devido à importância e repercussão que idéias do passado têm nos dias de hoje, além do prejuízo econômico que a escravidão causou à população negra. Como população escravizada, não pôde acumular bens para as gerações seguintes, e como foi dito, não tiveram nenhuma ajuda do Estado com o fim da escravidão. Depois veremos os estudos acadêmicos da década de 50, que mostraram haver racismo e desigualdade racial no Brasil, contradizendo a teoria da democracia racial, tornando-a um "mito", embora muitos a defendam até hoje. $\mathrm{Na}$ década de 70, Hasenbalg demonstrou que o racismo se renovava. E por fim, veremos as estatísticas mais recentes, que mostram a continuidade das desigualdades raciais. Todo esse quadro justifica as ações afirmativas para a população negra. Sem políticas focalizadas para a população negra, como as ações afirmativas, a igualdade racial dificilmente será alcançada.

\subsubsection{Perdas históricas acumuladas}

\section{Condições da escravidão}


Conforme Ferreira, "o homem de origem africana e seus valores foram sistematicamente associados a qualidades negativas pelo europeu, já antes do descobrimento do Brasil e do processo de colonização". ${ }^{21}$

Esse fato pode ser observado conforme a bula Romanus Pontifex, de 8 de janeiro de 1454, do papa Nicolau V:

Não sem grande alegria chegou ao nosso conhecimento que nosso dileto filho d. Henrique, incendido no ardor da fé e zelo da salvação das almas, se esforça por fazer conhecer e venerar em todo o orbe o nome gloriosíssimo de Deus, reduzindo à sua fé não só os sarracenos, inimigos dela, como também quaisquer outros infiéis. Guinéus e negros tomados pela força, outros legitimamente adquiridos foram trazidos ao reino, o que esperamos progrida até a conversão do povo ou ao menos de muitos mais. Por isso nós, tudo pensando com devida ponderação, concedemos ao dito rei Afonso a plena e livre faculdade, entre outras, de invadir, conquistar, subjugar a quaisquer sarracenos e pagãos, inimigos de Cristo, sua terra e seus bens, a todos reduzir à servidão e tudo praticar em utilidade própria e dos seus descendentes. Tudo declaramos pertencer de direito in perpetuum aos mesmos d. Afonso e seus sucessores, e ao infante. Se alguém, indivíduo ou coletividade, infringir essas determinações, seja excomungado. ${ }^{22}$

Presume-se que os primeiros africanos chegaram no Brasil entre 1516 e 1526, mas foi a partir de meados do século XVI que iniciou-se o fluxo regular e constante para a Colônia. ${ }^{23}$ Calcula-se que:

entre 1560 e 1850 o governo colonial brasileiro importou entre quatro milhões e meio e seis milhões de africanos para trabalhar como escravos nas plantações de cana, café, algodão, tabaco, nas minas de ouro e diamante, nas fazendas de gado e no trabalho doméstico e artesão ${ }^{24}$

Esses seres humanos "importados" atravessaram um oceano nos chamados "Navios Negreiros", ou "Tumbeiros", nas piores condições. Muitos morriam na viagem, e os que sobreviviam chegavam em péssimo estado. Essas mortes eram esperadas, tanto que os navios vinham superlotados, para compensar "as perdas do negócio". O termo "tumbeiro" significava, portanto, que os navios eram tumbas navegantes. Após o desembarque os escravos eram vendidos diretamente ou em leilões.

\footnotetext{
${ }^{21}$ FERREIRA, Ricardo Franklin. Afro-descendente - identidade em construção. São Paulo: EDUC; Rio de Janeiro: Pallas, 2004, p.40.

${ }^{22}$ Em RIBEIRO, D., apud FERREIRA, Ricardo Franklin. Op. cit. p.41.

${ }^{23}$ GOULART, Maurício. Apud BASTIDE, Roger \& FERNANDES, Florestan. Relações Raciais entre negros e brancos em São Paulo. São Paulo: Anhembi, 1955, p.16.

${ }^{24}$ GUIMARÃES, Antônio Sérgio Alfredo. Classes, raças e democracia. São Paulo: Editora 34, 2002, p. 118.
} 
Conforme Clóvis Moura, "quase $40 \%$ do total de africanos retirados do Continente Negro durante a existência do tráfico foram desembarcados no Brasil." ${ }^{25}$ Para este autor, o negro foi o grande povoador do nosso território.

A mão-de-obra escravizada sustentou diversas atividades econômicas no Brasil, em jornadas de trabalho de 14 a 16 horas diárias ${ }^{26}$. A média de vida útil do escravo era de 7 a 10 $\operatorname{anos}^{27}$. Na atividade de mineração, o negro "não leva apenas o seu trabalho, contudo, mas a sua cultura, ensinando técnicas de metalurgia e mineração, aperfeiçoando métodos de trabalho" 28 .

O negro escravizado vivia como se fosse um animal. A alimentação não era de fartura, como alguns autores descrevem. ${ }^{29}$ Segundo Vilhena:

(...) dever-se-ia de justiça e caridade providenciar sobre o bárbaro e cruel e inaudito modo como a maior parte dos senhores tratam os desgraçados escravos de trabalho. Tais há que não lhes dando sustento algum lhes facultam somente trabalharem no domingo ou dia santo em um pedacinho a que chamam 'roça' para daquele trabalho tirarem seu sustento para toda semana acudindo somente com alguma gota de mel, o mais grosseiro, se é tempo de moagem. ${ }^{30}$

Ainda quanto à alimentação, Ademar Vidal, baseado em testemunha da época afirma que:

A comida era jogada ao chão. Seminus, os escravos dela se apoderavam num salto de gato, comida misturada com areia, engolindo tudo sem mastigar porque não havia tempo a esperar diante dos mais espertos e mais vorazes. ${ }^{31}$

Segundo Moura, quanto ao tratamento violento e aos castigos:

Os dois instrumentos de suplício mais usados eram o tronco e o pelourinho, onde eram aplicadas as penas de açoite. O primeiro poderemos colocar como o símbolo da Justiça privada, e o segundo como símbolo da Justiça pública. Mas, de qualquer forma, a disciplina de trabalho imposta ao escravo baseava-se na violência contra a sua pessoa. Ao escravo fugido encontrado em quilombo

\footnotetext{
${ }^{25}$ MOURA, Clóvis. História do negro brasileiro. São Paulo: Ática, 1989, p. 10.

${ }^{26}$ Idem, p. 17

${ }^{27}$ Idem, p. 14

${ }^{28}$ Idem, p. 13

${ }^{29}$ Idem, p. 16

${ }^{30}$ VILHENA, Luís dos Santos. Apud MOURA, Clóvis. op. cit. p. 16-17.

${ }^{31}$ VIDAL, Ademar. Apud MOURA, Clóvis. op. cit. p. 17.
} 
mandava-se ferrar um F na testa e em caso de reincidência cortavam-lhe a orelha. O justiçamento do escravo era na maioria das vezes feito na própria fazenda pelo seu senhor, havendo casos de negros enterrados vivos, jogados em caldeirões de água ou azeite fervendo, castrados, deformados, além dos castigos corriqueiros, como os aplicados com a palmatória, o açoite, o vira-mundo, os anjinhos (...) e muitas outras formas de se coagir o negligente ou rebelde. ${ }^{32}$

Em termos jurídicos, conforme Prudente:

O Brasil não possui seu 'Código Negro', materialmente falando, a exemplo de outros estados americanos. As leis referentes aos escravos permanecem esparsas em normas das Ordenações Manuelinas, Filipinas e após 1822, em leis de natureza civil-comercial, e Código Criminal, Código de Processo Criminal, Codificação das Leis Civis, etc.

Mesmo após 1822 as Ordenações do Reino e inúmeras disposições do Direito Romano, permaneceram em vigor, utilizadas como subsidiária do Direito brasileiro para questões com escravos.

A Constituição Imperial outorgada por Dom Pedro I em 1824 era de cunho liberal, garantia considerável, rol de direitos humanos/individuais, herdados do ideário revolucionário (1789). Vigeu até 1889 , permitindo o trabalho escravo (1888), sobre o qual formalmente silenciava. ${ }^{33}$

Nesse aparato jurídico o negro poderia ser um objeto de direito, se fosse escravo, ou um sujeito de direito, se fosse alforriado, liberto. Como objeto de direito o escravo podia ser vendido, alugado, emprestado, hipotecado, pertencer a mais de um proprietário.

Conforme classificação de Teixeira de Freitas, Consolidação das Leis Civis (1958), os escravos pertenciam à classe dos bens móveis, ao lado dos semoventes. ${ }^{34}$

Os filhos eram denominados 'fructos' ou 'crias'. Com a morte do proprietário os escravos entravam no rol de bens a ser dividido pelos herdeiros. O negro liberto não tinha sua liberdade garantida.

Todavia as alforrias podiam ser revogadas por ingratidão do liberto para com seu patrono. Vigiam disposições das Ordenações do Reino, Livro IV, Título 63, parágrafo $7^{\circ}$, afrontando a Constituição Imperial (art. $7^{\circ}$ ), porque pela alforria o escravo entrava para o mundo livre. Tornava-se cidadão, brasileiro, entretanto, revogada a alforria, ocorria a reescravização, com perda dos direitos de cidadão. ${ }^{35}$

Quanto às penas, vejamos o art. 60 do Código Criminal do Império:

\footnotetext{
${ }^{32}$ MOURA, Clóvis. op. cit. p. 18.

${ }^{33}$ PRUDENTE, Eunice Aparecida de Jesus. "O negro na ordem jurídica brasileira". Revista da Faculdade de Direito USP, São Paulo, V.83, p. 136, 1988.

${ }^{34}$ FREITAS, Augusto Teixeira. apud PRUDENTE, Eunice Aparecida de Jesus, idem.

${ }^{35}$ PRUDENTE, Eunice Aparecida de Jesus, op. cit. p. 137.
} 
Se o Réu for escravo, e incorrer em pena que não seja a capital ou de galés será condenado na de açoites e, depois de as sofrer, será entregue a seu senhor, que se obrigará a trazê-lo com um ferro, pelo tempo e maneira que o juiz designar. ${ }^{36}$

A partir do século XIX, pressões internacionais contra a escravidão começaram a ocorrer, principalmente da Inglaterra, interessada na ampliação de mercados. Sob tais pressões em 1850 é promulgada a lei Eusébio de Queiroz, que proibiu o tráfico de africanos para o Brasil, porém o tráfico interno continuou, sendo os escravos comprados dos fazendeiros do norte pelos fazendeiros do sul, onde as plantações de café se desenvolviam, exigindo cada vez mais mão-de-obra. Conforme Viotti da Costa, São Paulo, Minas Gerais e Rio de Janeiro detinham, em $1887,50 \%$ da população escrava do país. ${ }^{37}$

O fim do tráfico de escravos e a taxa de mortalidade dos escravos fizeram decrescer a mão-de-obra escravizada, conseqüentemente alimentando políticas de imigração, com preferência à imigração européia.

A Guerra do Paraguai (1865-1870) ajudou a desarticular a escravidão. Segundo Prudente:

Somente um conflito internacional de grandes proporções, envolvendo interesses capitalistas da Inglaterra, - Guerra contra o Paraguai - , seguida de revoltas intestinas promovidas pelos negros excombatentes, vitoriosos; conseguiram desarticular o sistema escravista no Brasil. São as mesmas armas utilizadas na Guerra do Paraguai que promovem fugas maciças de escravos e a formação de novos quilombos. ${ }^{38}$

Segundo Moura, na Guerra do Paraguai, morreram cerca de 90000 negros $^{39}$, onde, segundo o autor:

Essa grande sucção de mão-de-obra negra, provocada pela Guerra do Paraguai, abriu espaços ainda maiores para que o imigrante fosse aproveitado como trabalhador. Essa tática de enviar negros à guerra serviu, de um lado, para branquear a população brasileira e, de outro, para justificar a política

\footnotetext{
${ }^{36}$ Código Criminal do Império do Brasil, artigo 60, apud PRUDENTE, Eunice Aparecida de Jesus, op. cit. p. 138.

${ }^{37}$ VIOTTI DA COSTA, Emília. Apud ibdem, p. 55

${ }^{38}$ PRUDENTE, Eunice Aparecida de Jesus. "O negro na ordem jurídica brasileira". Revista da Faculdade de Direito USP, São Paulo, V.83, p. 139, 1988.

${ }^{39}$ MOURA, Clóvis. História do negro brasileiro. São Paulo: Ática, 1989, p. 57
} 
imigrantista que era patrocinada por parcelas significativas do capitalismo nativo e pelo governo de D. Pedro II. ${ }^{40}$

O desenvolvimento dos centros urbanos estimulou o crescimento de um movimento abolicionista, o qual era essencialmente urbano e formado por intelectuais brancos, (com exceção de líderes negros como José do Patrocínio, André Rebouças e Joaquim Nabuco) que acreditavam ser a escravidão um impedimento para o desenvolvimento do Brasil. Surgem leis como a Rio Branco (Lei do Ventre Livre) em 28 de setembro de 1871, que libertava todos filhos de escravizadas nascidos a partir daquela data e a Saraiva-Cotegipe (Lei do Sexagenário) em 28 de setembro de 1885, que libertava os escravizados velhos, que completassem 65 anos . Essas leis, apesar das aparentes boas intenções, não eram de fato benéficas aos escravizados. A lei do Ventre Livre, por exemplo, em seu primeiro artigo dizia:

Art. $1^{\circ}$ - Os filhos da mulher escrava, que nascerem no império desde a data desta lei, serão considerados de condição livre.

$\S 1^{\circ}$ - Os ditos filhos menores ficarão em poder e sob autoridade dos senhores de suas mães, os quais terão obrigação de criá-los até a idade de oito anos completos. Chegando o filho da escrava a esta idade o senhor da mãe terá a opção ou de receber do estado a indenização de $600 \$ 000$ ou de utilizar-se dos serviços do menor até 21 anos completos. ${ }^{41}$

Ou seja, ou o "liberto" continuava escravizado até os 21 anos, ou acabava sendo entregue ao Estado, terminando abandonado pelas ruas da cidade.

Quanto à lei do Sexagenário:

serviu para descartar a população escrava não produtiva, que apenas existia como sucata e dava despesas aos seus senhores. ${ }^{42}$

Ou seja, esses velhos também acabavam abandonados pelas ruas da cidade.

Finalmente, em 13 de maio de 1888 é promulgada em dois artigos, a Lei Áurea, abolindo a escravidão do Brasil:

\footnotetext{
${ }^{40}$ Ibdem, p. 57.

${ }^{41}$ Em PRUDENTE, Eunice Aparecida de Jesus. Op. cit. p. 139.

${ }^{42}$ MOURA, Clóvis. Op. cit. p. 57.
} 


\section{“LEI No 3.353, DE 13 DE MAIO DE 1888.}

Declara extinta a escravidão no Brasil.

A Princesa Imperial Regente, em nome de Sua Majestade o Imperador, o Senhor D. Pedro II, faz saber a todos os súditos do Império que a Assembléia Geral decretou e ela sancionou a lei seguinte:

Art. $1^{\circ}:$ É declarada extincta desde a data desta lei a escravidão no Brazil.

Art. $2^{\circ}$ : Revogam-se as disposições em contrário.

Manda, portanto, a todas as autoridades, a quem o conhecimento e execução da referida Lei pertencer, que a cumpram, e façam cumprir e guardar tão inteiramente como nella se contém."

\section{Período Pós-abolição}

Vinda a liberdade, o que aconteceu? Muitos ex-escravos deixaram as fazendas onde eram escravos, com a roupa do corpo, indo para as cidades, onde, marginalizados e desempregados, pois estavam acostumados ao trabalho do campo, passaram a viver em barracos. Outros permaneceram no campo, praticando uma economia de subsistência. Outros ainda se embrenharam no mato, constituindo novos quilombos. Calcula-se que $1 / 4$ permaneceram nas fazendas. Em qualquer dos casos, o fator comum para eles foi a miséria. Por quê?

Notemos que após a abolição não houve nenhuma política estatal a favor dos negros. Houve uma discussão no parlamento brasileiro se os proprietários de escravos deveriam ser indenizados ou não. Optou-se por não pagar nada e o jurista Rui Barbosa, embora fosse da opinião de que se alguém deveria ser indenizado, que fossem os ex-escravos, ordenou a queima dos arquivos referentes a escravidão no Brasil para evitar reivindicações indenizatórias 
pelos ex-proprietários. O resultado disso foi uma perda lastimável para a recuperação da memória nacional.

Dada a necessidade de mão-de-obra para as lavouras do café, o Estado Brasileiro entre 1884 e 1913 estimulou o ingresso de 2,7 milhões de europeus no Brasil. A preferência do governo brasileiro pelo imigrante europeu era clara, como vemos no Decreto $\mathrm{n}^{\mathrm{o}} 528$, de 28 de junho de 1890 em seu artigo primeiro:

É inteiramente livre a entrada, por portões da República, dos indivíduos válidos e aptos para o trabalho... excetuados os indígenas da Ásia e da África. ${ }^{43}$

Ou seja, depois de mais de três séculos de trabalhos forçados, uma vez finda a escravidão, o negro não era mais bem-vindo ao Brasil.

O negro competia com essa mão-de-obra européia e obtinha os empregos menos remunerados quando não ficava desempregado. Além disso, enquanto não houve nenhuma política pública para os ex-escravos, o governo optou por gastar com a imigração européia: centenas de colônias estrangeiras foram implantadas no sul do Brasil, tendo os imigrantes recebido terras do governo.

Segundo Prudente, o Direito brasileiro exerceu funções distintas quanto ao grupo de imigrantes e quanto ao grupo de escravizados:

Leis imigratórias $=$ Direito com vistas à Promoção Humana: caráter benéfico: 1 . salário; 2 . proteção à família; 3. educação às crianças; 4. reconhecimento do casamento protestante; 5 . respeita lideranças oficiais: diplomatas, padres, pastores. Objetivo = integrar a família do imigrante ao Brasil.

Leis escravistas: Direito mantenedor do 'status quo': caráter punitivo: 1. destruição do ego; 2. descaracterização da cultura; 3 . sujeição à prisão e às penas domésticas; 4. impedimentos à formação de núcleo familiar; 5. proibição à qualquer ação conjunta; 6. disseminação do medo/desconfiança; 7. morte às lideranças. Objetivo: dividir para submeter. ${ }^{44}$

A mulher negra teve papel preponderante no sustento da família, nesse período.

\footnotetext{
${ }^{43}$ RODRIGUES, José Honório apud PRUDENTE, Eunice Aparecida de Jesus, op. cit. p. 141.

${ }^{44}$ PRUDENTE, Eunice Aparecida de Jesus, op. cit. p. 140.
} 
Se não fosse a mulher negra garantir a sobrevivência de sua família, trabalhando como empregada doméstica, a raça negra não teria sobrevivido à miserabilidade das primeiras décadas de cidadania. ${ }^{45}$

O favorecimento à imigração européia teve respaldo nas teses racistas tidas como científicas, importadas da Europa, que culminaram na política nacional do branqueamento. As teses racistas tinham como pano de fundo explicar o sucesso econômico do norte da Europa no seu processo de colonialismo. A dominação dos europeus do norte era explicada pela superioridade de sua raça, e das condições do meio físico mais favoráveis. Conforme Skidmore:

\begin{abstract}
Em resumo, os europeus do norte eram raças 'superiores' e gozavam do clima 'ideal'. O que, por certo, implicava em admitir, implicitamente, que raças mais escuras ou climas tropicais nunca seriam capazes de produzir civilizações comparativamente evoluídas. (...) Não por coincidência, tal análise era dirigida à área que tinha sucumbido à conquista européia a partir do séc. XV: África $\mathrm{e}$ América Latina. ${ }^{46}$
\end{abstract}

Das teses racistas importadas, destaquemos a de Joseph Arthur de Gobineau (18161882), que foi um diplomata e escritor francês. Sua principal obra "Essai sur l'inégalité des races humaines" (Ensaio sobre a desigualdade das raças humanas), foi publicada em 4 volumes, entre os anos de 1883 e 1885. Sua obra influenciou sua época e as teses nazistafascistas, no século seguinte.

Gobineau perguntava, no seu trabalho, por que as civilizações nascem e por que elas desaparecem. Para Gobineau, as civilizações desaparecem devido à degeneração, a qual ocorre por causa da miscigenação. A civilização só se desenvolve quando uma nação conquista a outra. Porém as sucessivas misturas enfraquecem a raça superior, e então ocorre a decadência daquela civilização. ${ }^{47}$ Conforme Munanga:

Eis a essência da filosofia da história de Gobineau. A raça suprema entre os homens é a raça ariana, da qual os alemães são os representantes modernos mais puros. Todas as civilizações resultam das conquistas arianas sobre os povos mais fracos; começaram todas a declinar quando o sangue ariano diluiu-se por cruzamentos. Os brancos ultrapassam todos os outros em beleza física. Os povos que

\footnotetext{
${ }^{45}$ Idem, p. 141

${ }^{46}$ SKIDMORE, Thomas E. Preto no Branco. Rio de Janeiro: Editora Paz e Terra, 1989. p. 44.

${ }^{47}$ MUNANGA, Kabengele. Rediscutindo a mestiçagem no Brasil: identidade nacional versus identidade negra. Belo Horizonte: Autêntica, 2004, p.48
} 
não têm o sangue dos brancos aproximam-se da beleza, mas não a atingem. De todas as misturas raciais, as piores, do ponto de vista da beleza, são formadas pelo casamento de brancos e negros. ${ }^{48}$

Como diplomata Gobineau esteve aqui, no Brasil, em 1869. Nunca escondeu o desgosto pelo país, o qual condenava pela miscigenação. Para ele, o Brasil tinha:

$\mathrm{Na}$ virada do século XIX para o século XX, o pensamento racista no Brasil desenvolveuse através de vários intelectuais. Destaquemos Sílvio Romero (1851-1914), João Batista de Lacerda (1846-1915) e Nina Rodrigues (1862-1906). Eles defendiam a tese da superioridade da raça branca. Para Sílvio Romero e João Batista de Lacerda, o branqueamento do povo brasileiro melhoraria a "raça" brasileira. Segundo Skidmore a teoria brasileira do branqueamento:

Aceita pela maior parte da elite brasileira nos anos que vão de 1889 a 1914, era teoria peculiar do Brasil. Poucas vezes apresentada como fórmula 'científica', e jamais adotada na Europa ou nos Estados Unidos - merece ser explicada aqui com algum detalhe. A tese do branqueamento baseavase na presunção da superioridade branca, às vezes, pelo uso dos eufemismos raças 'mais adiantadas' e 'menos adiantadas', e pelo fato de ficar em aberto a questão de ser a inferioridade inata. À suposição inicial, juntavam-se mais duas. Primeiro - a população negra diminuía progressivamente em relação à branca por motivos que incluíam a suposta taxa de natalidade mais baixa, a maior incidência de doenças, e a desorganização social. Segundo - a miscigenação produzia 'naturalmente', uma população mais clara, em parte porque o gene branco era mais forte e em parte porque as pessoas procurassem parceiros mais claros do que elas. ${ }^{49}$

O próprio Joaquim Nabuco, líder abolicionista, tinha como alvo um Brasil mais branco.

Segundo ele, os abolicionistas queriam um país:

onde, atraída pela franqueza das nossas instituições e pela liberalidade do nosso regime, a imigração européia traga sem cessar para os trópicos uma corrente de sangue caucásico vivaz, enérgico e sadio, que possamos absorver sem perigo... ${ }^{50}$

Via-se, que o objetivo era um aprimoramento eugênico, mas pela preferência da introdução no país dos europeus, preferencialmente os do norte da Europa. Essa introdução do elemento branco europeu no Brasil dar-se-ia por políticas do Estado promovendo a imigração desse contingente. Como se daria o branqueamento? Primeiro pelo aumento do número de brancos na população. Segundo, o povo brasileiro, mestiço, misturar-se-ia com os imigrantes

\footnotetext{
${ }^{48}$ Ibdem, p. 49.

${ }^{49}$ SKIDMORE, Thomas E. op. cit. , p. 81.

${ }^{50}$ NABUCO, J. apud SKIDMORE, Thomas E. op. cit. , p. 40.
} 
brancos, e, dadas algumas gerações, o "sangue" branco predominaria sobre o negro e o indígena.

Sílvio Romero, (Sílvio Vasconcelos da Silveira Ramos Romero), nasceu em Sergipe, e foi crítico literário, ensaísta, professor e historiador da literatura brasileira. Conforme Skidmore, Sílvio Romero:

Visualizava o Brasil como produto de três correntes raciais: o branco europeu, o negro africano e o índio aborígene. As opiniões que expressou sobre cada uma delas eram pouco encorajadoras. Do ramo particular branco (Greco-latino) que veio para o Brasil - com os portugueses - tem a mesma opinião dos românticos que haviam popularizado o nacionalismo cultural, isto é, que era inferior ao ramo 'germano-saxão'. 51

Quanto aos índios, eram "certamente os mais decaídos na escala etnográfica",52, e os africanos eram "derrotados na escala etnográfica"

Quanto ao futuro do Brasil, Sílvio Romero preconizava o predomínio do elemento branco graças ao fim do tráfico negreiro, ao desaparecimento dos índios e à imigração européia:

A minha tese, pois, é que a vitória na luta pela vida entre nós, pertencerá, no porvir, ao branco; mas que esse, para essa mesma vitória atentas as agruras do clima, tem necessidade de aproveitar-se do que de útil as outras duas raças lhe podem fornecer, maximé a preta, com que tem mais cruzado. Pela seleção natural, todavia, depois de prestado o auxílio de que necessita, o tipo branco irá tomando a preponderância até mostrar-se puro e belo como no velho mundo. Será quando já estiver de todo aclimatado no continente. Dois fatos contribuirão largamente para esse resultado: de um lado, a extinção do tráfico africano e o desaparecimento constante dos índios, e de outro a emigração européia. ${ }^{54}$

João Batista de Lacerda (1845-1915), nasceu no Rio de Janeiro e formou-se médico pela faculdade do Rio de Janeiro. Foi diretor do Museu Nacional, e nessa função foi representar o Brasil no Primeiro Congresso Universal das Raças, em Londres, 1911. O discurso que proferiu "Sur les métis au Brésil" é bastante ilustrativo da tese do branqueamento. Conforme Silva:

\footnotetext{
${ }^{51}$ SKIDMORE, Thomas E. op. cit. , p. 51.

${ }^{52}$ ROMERO, Sílvio. Apud SKIDMORE, Thomas E. op. cit. , p. 51.

${ }^{53}$ ROMERO, Sílvio. Apud SKIDMORE, Thomas E. op. cit. , p. 51.

${ }^{54}$ ROMERO, Sílvio. Apud SKIDMORE, Thomas E. op. cit. , p. 53.
} 
No texto que apresenta no Congresso, Sur les Métis, [Lacerda] reconhece a inferioridade racial do negro, porém resolve enaltecer o mulato, que não seria tão forte fisicamente quanto o negro mas teria herdado a inteligência do branco. Estima que em cem anos o Brasil teria uma maioria branca, 'latina', e que os negros e índios teriam sido 'extintos'. ${ }^{55}$

Hofbauer acha curioso que a exposição de Lacerda tenha recebido severas críticas no Brasil:

O cientista foi acusado de ter apresentado uma imagem prejudicial ao país: houve quem achasse os números estatísticos a respeito da população de cor muito altos e muito longo o prazo estipulado por ele para a diminuição e o desaparecimento total dos negros. ${ }^{56}$

Raimundo Nina Rodrigues (1862-1906) nasceu no Maranhão, na cidade que hoje tem seu nome. Estudou medicina na Bahia e no Rio de Janeiro, onde concluiu o curso. Foi professor da faculdade de medicina da Bahia.

Segundo Skidmore, Nina Rodrigues, jovem doutor mulato, pelo fim da década de 1890 já se distinguia como pioneiro em dois campos: etnologia afro-brasileira e medicina legal. Até sua época nenhum desses campos era reconhecido como área de pesquisa, mas "seus esforços contribuíram para lançar-lhes as bases de estudo no Brasil". ${ }^{57}$ Para Skidmore, Nina Rodrigues tornou-se o principal doutrinador racista brasileiro de sua época. ${ }^{58}$

Em 1894, Nina Rodrigues publicou seu primeiro livro "As raças humanas e a responsabilidade penal no Brasil”, onde ele defende a idéia de que as raças inferiores (no caso os índios e os negros), não deveriam ter a mesma responsabilidade criminal que as raças superiores, ou seja, as raças menos evoluídas deveriam ter sua responsabilidade criminal atenuada. ${ }^{59}$ E quanto aos mestiços? Seu caráter é influenciado conforme as raças inferiores de

\footnotetext{
${ }^{55}$ SILVA, Jorge. " Política de ação afirmativa para a população negra: educação, trabalho e participação no poder". In: VOGEL, Arno (org.). Trabalhando com a diversidade no Planfor: raça/cor, gênero e pessoas portadoras de necessidades especiais. UNESP: Brasília, 2000, p.14.

${ }^{56}$ HOFBAUER, Andreas. Uma história de branqueamento ou o negro em questão. São Paulo: Editora UNESP, 2006, p. 211.

${ }^{57}$ SKIDMORE, Thomas E. op. cit. , p. 74

${ }^{58}$ SKIDMORE, Thomas E. op. cit. , p. 75

${ }^{59}$ NINA RODRIGUES, R. As raças humanas e a responsabilidade penal no Brazil. Bahia, 1894. Consulta na internet, endereço http://bdjur.stj.gov.br, acesso em 20-11-2007, p.86.
} 
que são miscigenados e o seu caráter variado se dá conforme o gradiente de miscigenação, e é em função desse gradiente que se dá a variação na responsabilidade penal. ${ }^{60}$

Quanto à mulata, ele considera sua excitabilidade de um tipo anormal:

A sensualidade do negro pode atingir então ás raias quase das perversões sexuaes mórbidas. A excitação genésica da clássica mulata brazileira não póde deixar de ser considerada um typo anormal. $^{61}$

Para Nina Rodrigues, a inferioridade da população negra é um dado científico:

O critério científico da inferioridade da raça negra nada tem de comum com a revoltante exploração que dela fizeram os interesses escravistas dos norte-americanos. Para a ciência não é esta inferioridade mais do que um fenômeno de ordem perfeitamente natural, produto da marcha desigual do desenvolvimento filogenético da humanidade nas suas diversas divisões ou seções. ${ }^{62}$

Além da importação de idéias racistas, da ideologia do branqueamento, que considerava o negro inferior, o qual deveria se extinguir a fim de melhorar a "raça" brasileira, surgiu na década de 30 a ideologia da democracia racial. A expressão "democracia racial" só foi cunhada, de fato, segundo Guimarães, por Roger Bastide, em artigo publicado no Diário de São Paulo, em 31 de março de $1944 .^{63}$

Para Andrews, o conceito de democracia racial:

Estabelece que o Brasil é uma terra inteiramente livre de impedimentos legais e institucionais para a igualdade racial, e em grande parte (particularmente em comparação com países como os Estados Unidos) também isento de preconceito e discriminação raciais informais. A nação oferece a todos os seus cidadãos - negros, mulatos ou brancos - uma igualdade de oportunidade virtualmente completa em todas as áreas da vida pública: educação, política, empregos, moradia. ${ }^{64}$

Embora o termo "democracia racial", tenha sido cunhado em 1944, para Andrews, o ideário da democracia racial foi tomando forma nas primeiras décadas do século $\mathrm{XX}$, sendo

\footnotetext{
${ }^{60}$ Idem, p.93

${ }^{61}$ Idem, p. 102

${ }^{6}$ NINA RODRIGUES, R. Os africanos no Brasil. São Paulo: Nacional, Brasília: Universidade de Brasília, 1988 , p. 5.

${ }^{63}$ GUIMARÃES, Antônio Sérgio Alfredo. Classes, raças, e democracia. São Paulo: Editora 34, 2002 , p. 138.

${ }^{64}$ ANDREWS, George Reid. Negros e brancos em São Paulo (1988-1988). Bauru: Edusc, 1998, p. 203.
} 
que o conceito de democracia racial recebeu sua interpretação mais plena e mais coerente nos escritos de Gilberto Freyre, iniciados na década de $1930^{65}$.

O gérmen da democracia racial no Brasil emerge desde a época da escravidão, por haver negros libertos e mulatos com algum grau de ascensão social. Segundo Andrews:

No decorrer do século XIX, as restrições raciais datadas do domínio colonial português eram explicitamente declaradas ilegais ou simplesmente caíam em desuso, permitindo que uma proporção visível de pretos e pardos livres experimentassem uma importante mobilidade ascendente na sociedade brasileira. Os observadores estrangeiros, em particular, ficavam impressionados com a aparente liberdade dos negros para ascender até o ponto onde seus talentos os levassem. ${ }^{66}$

Segundo o autor, as observações feitas podem ter exagerado as oportunidades que realmente existiram no Brasil, mas sugerem que durante o império, o Brasil era uma sociedade com mais igualdade racial em comparação com os EUA. ${ }^{67}$

$\mathrm{Na}$ época, os senhores de escravos no Brasil falavam que seus escravos eram tratados muito melhor que os escravos de outras localidades, e que a escravidão era branda e leve. Esse "mito da escravidão brasileira benevolente" foi aceito e persistiu nos anos seqüentes. Servia para aliviar a consciência dos senhores de escravos (que eram todos cristãos) e servia para defender a instituição dos críticos brasileiros e estrangeiros. ${ }^{68}$

Florestan também fala que a democracia racial teria seu gérmen na idéia de uma escravidão branda, ou seja, o mito de uma democracia racial "germinou longamente, em todas avaliações que pintavam o jugo escravo como contendo 'muito pouco fel' e sendo suave, doce e cristãmente humano." No entanto, a idéia de uma democracia racial não possuía sentido naquela sociedade escravocrata e senhorial, onde "a ordenação das relações exigia a manifestação aberta, regular e irresistível do preconceito e da discriminação raciais."69

\footnotetext{
${ }^{65}$ Idem, p. 203.

${ }^{66}$ Idem, p. 203.

${ }^{67}$ Ibdem, p. 204.

${ }^{68}$ Ibdem, p. 205

${ }^{69}$ FERNANDES, Florestan. A integração do negro na sociedade de classses. São Paulo: Ática, xxx, vol. 1 p. 254.
} 
Logo após a abolição, ocorreu a proclamação da República, com ideais democráticos. No entanto, embora essa fosse a visão propalada, a realidade mostrou-se oposta. No campo político predominou um governo oligárquico e autoritário, com eleições fraudulentas, o oposto da participação prometida pela República. Quanto à pretendida igualdade racial:

Estava claro para todos que os negros continuavam a ocupar uma posição rebaixada e subordinada na sociedade brasileira. Mas, proclamando que, mesmo durante a escravidão, o Brasil se movimentou rumo à igualdade racial, e com a abolição de 1888 a alcançou, a doutrina da democracia racial isentava a política do Estado ou o racismo informal de qualquer responsabilidade adicional pela situação da população negra, e até mesmo colocou esta responsabilidade diretamente nos ombros dos próprios afro-brasileiros. ${ }^{70}$

Como poderia a responsabilidade da desigualdade ser colocada sobre os ombros dos próprios negros? Muito simples: se aceitássemos que existia igualdade no Brasil, a desigualdade só poderia advir das deficiências dos negros.

Mas os negros sabiam que a desigualdade provinha do racismo. Na década de 20 encontramos uma imprensa negra denunciando as práticas racistas. Vejamos uma citação de um observador que fala da dificuldade do homem negro em conseguir emprego. O homem negro:

vae às fábricas, mas não lhe dão serviço, [e] muitas vezes nem deixam falar com os gerentes. Procura annúncios nos jornaes, corre pressuroso onde precisam de empregados, e embora chegue primeiro do que qualquer outro candidato, por ser de cor é posto à margem e recusado... é um phenômeno social muito conhecido em S. Paulo, não só na capital como em quase todas as cidades do interior, phenômeno esse que dia a dia cresce... ${ }^{71}$

Afora a dificuldade em conseguir emprego, os negros sofriam discriminação racial nos serviços e edifícios públicos. A discriminação era mais acentuada no interior do Estado. Os negros passavam por situações humilhantes em bares, hotéis, restaurantes, barbearias e praças públicas. Conforme Andrews:

Os jornais negros localizados na capital regularmente comentavam incidentes de negros que não eram servidos em bares, hotéis, restaurantes e barbearias nas cidades menores do Estado. Uma fonte ocasional de conflito era a questão do acesso dos negros aos parques e praças públicas, onde os moradores se reuniam para seus passeios ou 'footings' à noite e nos sábados à tarde. Os negros

\footnotetext{
${ }^{70}$ ANDREWS, George Reid. Op. cit. p.210

71 "Os pretos em São Paulo", O Kosmos (19 de outubro de 1924). Apud ANDREWS, George Reid. Op. cit. p.215-216
} 
tinham permissão para se reunir contanto que se mantivessem restritos a uma área específica do parque ou da praça. ${ }^{72}$

Com Getúlio Vargas no poder em 1930, toma corpo uma nova ideologia, a da identidade nacional, teorizada por Gilberto Freyre e outros. Essa ideologia preconiza o caráter mestiço da população brasileira, mestiçagem entre as três raças: branca, negra e índia, a qual teria ocorrido tanto no campo biológico quanto cultural, levando à superação do racismo.

Gilberto Freyre nasceu em 15 de março de 1900, na cidade de Recife. Em 1933 publica Casa Grande \& Senzala. Casa Grande \& Senzala fala da interação e miscigenação das três raças no Brasil: a branca, negra e índia, o que produziu zonas de confraternização e relações que se amenizaram:

Vencedores no sentido militar e técnico sobre as populações indígenas; dominadores absolutos dos negros importados da África para o duro trabalho da bagaceira, os europeus e seus descendentes tiveram entretanto de transigir com índios e africanos quanto às relações genéticas e sociais. A escassez de mulheres brancas criou zonas de confraternização entre vencedores e vencidos, entre senhores e escravos. Sem deixarem de ser relações - as dos brancos com as mulheres de cor - de 'superiores' com 'inferiores' e, no maior número de casos, de senhores desabusados e sádicos com escravas passivas, adoçaram-se, entretanto, com a necessidade experimentada por muitos colonos de constituírem família dentro dessas circunstâncias e sobre essa base. A miscigenação que largamente se praticou aqui corrigiu a distância social que de outro modo se teria conservado enorme entre a casa-grande e a mata tropical; entre a casa grande e a senzala. ${ }^{73}$

Freyre fala de doçuras dos senhores com os escravos domésticos:

Mas aceita, de modo geral, como deletéria a influência da escravidão doméstica sobre a moral e o caráter do brasileiro da casa-grande, devemos atender às circunstâncias especialíssimas que entre nós modificaram ou atenuaram os males do sistema. Desde logo salientamos a doçura nas relações de senhores com escravos domésticos, talvez maior no Brasil do que em qualquer outra parte da América. $^{74}$

Quanto à sexualidade, havia sempre a presença da mulher negra na vida do brasileiro.

Freyre relata o caso:

\footnotetext{
${ }^{72}$ ANDREWS, George Reid. Op. cit. p.216-217

${ }^{73}$ FREYRE, Gilberto. Casa grande \& Senzala. São Paulo: Global Editora, 2006, $51^{\text {a }}$ edição, p. 33.

${ }^{74}$ Ibdem, p. 435.
} 
(...) de um jovem de conhecida família escravocrata do Sul: este para excitar-se diante da noiva branca precisou, nas primeiras noites de casado, de levar para a alcova a camisa úmida de suor, impregnada de budum, da escrava negra sua amante. ${ }^{75}$

Os meninos brancos iniciavam sua vida sexual com as negras:

Nenhuma casa grande do tempo da escravidão quis para si a glória de conservar filhos maricas ou donzelões." (...) "Se este foi sempre o ponto de vista da casa-grande, como responsabilizar-se a negra da senzala pela depravação precoce do menino dos tempos patriarcais? O que a negra da senzala fez foi facilitar a depravação com a sua docilidade de escrava; abrindo as pernas ao primeiro desejo do sinhô-moço. Desejo, não: ordem. ${ }^{76}$

Freyre traça um panorama do senhor de engenho deitado constantemente numa rede, dando suas ordens e copulando:

Ociosa, mas alagada de preocupações sexuais, a vida do senhor de engenho tornou-se uma vida de rede. Rede parada, com o senhor descansando, dormindo, cochilando. Rede andando, com o senhor em viagem ou a passeio debaixo de tapetes ou cortinas. Rede rangendo, com o senhor copulando dentro dela. ${ }^{77}$

Além dos exemplos citados acima, Freyre fala da contribuição do negro na culinária, linguagem e religião, enfim, na cultura brasileira. A influência da obra de Freyre é enorme, e as opiniões sobre sua obra divergentes. Há os comentários elogiosos, pois falando da miscigenação e da contribuição dos negros na cultura brasileira, Freyre valorizaria a confraternização racial e se contraporia às teses de branqueamento vigentes na época. Conforme Gorender:

Opondo-se ao enfoque racista ainda em voga, na época, com Oliveira Viana, o sociólogo pernambucano contestou a tese sobre a inferioridade do negro. Valorizou a contribuição racial e cultural dos africanos à formação da nação brasileira e viu na miscigenação uma via de convivência salutar entre os segmentos raciais diversos. ${ }^{78}$

Essa convivência salutar ou democracia racial é contradita por diversos autores, como veremos mais à frente. A harmonia entre as três raças, a dita "confraternização" racial ocorrida graças à miscigenação não tem correspondente na realidade, o que a realidade mostra são desigualdades raciais. Segundo Silva:

\footnotetext{
${ }^{75}$ Ibdem, p. 368.

${ }^{77}$ Ibdem, p.456.

${ }^{77}$ Ibdem, p. 518.

${ }^{78}$ GORENDER, Jacob. Brasil em preto \& branco. São Paulo: Editora SENAC, 2001, p. 57.
} 
A 'fábula das três raças' continua a ser contada pelo sistema de ensino, quase sempre acriticamente e de forma igualmente ufanista, assim como continua a ser repassada pela literatura e pelos meios de comunicação em geral. (...) Contada para crianças negras, muitas vezes humilhadas por esse fato na própria escola, e na rua. Que sabem das humilhações a que seus pais, parentes e amigos são submetidos no dia-a-dia. Não há como manter de fora da explicação os problemas que qualquer sociedade tem. Ora, que sociedade maravilhosa é esta, sem conflitos, sem classes, sem preconceitos? Por que Gilberto Freyre deixou de fora a perseguição às religiões e cultos de origem africana, aos capoeiras e às escolas de samba? Por que não falou da discriminação explícita nos lugares públicos, clubes, escolas e no emprego; e a prisão para averiguações de 'suspeitos', práticas tão corriqueiras na época em que escreveu o livro? ${ }^{79}$

\section{A Democracia Racial foi desmascarada pela primeira vez pela Frente Negra e pela segunda vez, em pesquisa acadêmica patrocinada pela UNESCO nas décadas 50/60 Conforme Munanga:}

Trata-se realmente de um mito porque a mistura não produziu a declarada democracia racial, como é demonstrado pelas inúmeras desigualdades sociais e raciais que o próprio mito ajuda a dissimular, dificultando até a formação da consciência e da identidade política dos membros dos grupos oprimidos. ${ }^{80}$

${ }^{79}$ SILVA, Jorge. "Política de ação afirmativa para a população negra: educação, trabalho e participação no poder". In: VOGEL, Arno (org.). Trabalhando com a diversidade no Planfor: raça/cor, gênero e pessoas portadoras de necessidades especiais. UNESP: Brasília, 2000, p 24-25.

${ }^{80}$ MUNANGA, Kabengele. "Mestiçagem e experiências interculturais no Brasil". In:SCHWARCZ, Lilia Moritz, REIS, Letícia Vidor de Souza (org.). Negras imagens: ensaios sobre cultura e escravidão no Brasil. São

Paulo: Edusp, 1996, p. 190. 


\subsubsection{Pesquisas em Sociologia e Antropologia}

Nos anos de 1951 e 1952, a UNESCO, Organização das Nações Unidas para a Educação, Ciência e Cultura, patrocinou uma série de pesquisas a respeito das relaçõ es raciais no Brasil, nas regiões Nordeste e Sudeste. A UNESCO estava interessada na propagada democracia racial que existiria no Brasil, que faria deste país um "paraíso racial”, diferentemente do “apartheid” na África do Sul e da segregação racial nos EUA.

Os antropólogos Alfred Métraux e Ruy Coelho foram os dirigentes responsáveis pelo projeto de pesquisa a ser realizado no Brasil. Inicialmente, a pesquisa seria realizada apenas no Estado da Bahia, que havia, nos anos de 30 e 40, atraído diversos pesquisadores. O antropólogo norte-americano, Charles Wagley, estava na Bahia envolvido num projeto de estudo de três comunidades rurais próximas a Salvador. Wagley informou Métraux do projeto, e dispôs-se a um trabalho conjunto com a Unesco, idéia que foi bem acolhida. Wagley sugeriu a investigação da cidade de Salvador, que ficaria sob a responsabilidade do médicoantropólogo Thales de Azevedo. Essa idéia também foi bem acolhida e depois, alguns cientistas sociais sugeriram um aumento do escopo da pesquisa. Luiz de Aguiar Costa Pinto, sociólogo, em correspondência com Métraux, manifestou interesse que o Departamento de Ciências Sociais da Faculdade Nacional de Filosofia, vinculado à Universidade do Brasil (Rio de Janeiro), realizasse, no Rio de Janeiro, pesquisas dentro do plano da Unesco. Métraux entrou em contato com Roger Bastide. Este, desde 1938 era professor da Universidade de São Paulo e estudioso da cultura afro-brasileira. Ambos já se conheciam e tinham afinidades intelectuais. Métraux visitou o Brasil no final de 1950 e optou por incluir Rio de Janeiro e São Paulo na pesquisa, dadas suas características de modernização. A pesquisa só ficou definida no ano seguinte, quando Métraux, em nova visita ao Brasil incluiu a cidade de Recife, graças à proposta de Gilberto Freyre a qual consistia em incluir na pesquisa o IJN (Instituto Joaquim Nabuco), órgão criado por Freyre em $1949 .{ }^{81}$

\footnotetext{
${ }^{81}$ MAIO, Marcos Chor. "O projeto Unesco e a Agenda das Ciências Sociais no Brasil dos anos 40 e 50 ." Revista Brasileira de Ciências Sociais. $\mathrm{N}^{\circ} 41$ (14): 141-158, outubro/1999. Consulta na internet no endereço www.scielo.br.pdf.rbcsoc/v14n41/1756.pdf, acesso em 27/09/2007.
} 
Os resultados das pesquisas não corroboraram a existência da democracia racial. Nas localidades estudadas as equipes constataram elevada desigualdade entre a população branca e negra, além de atitudes e estereótipos racistas. Os pesquisadores do Nordeste diferiram dos pesquisadores do Sudeste ao considerar que as desigualdades expressavam mais as diferenças de classe do que as diferenças raciais. Os pesquisadores de São Paulo e do Rio de Janeiro deram ênfase à discriminação racial, notando tratamento diferente para brancos e negros na classe trabalhadora e as enormes dificuldades encontradas por negros e mulatos cultos e qualificados para se introduzirem na classe média. ${ }^{82}$

\section{Escola Paulista de Sociologia}

Bastide concordou em participar da pesquisa da Unesco e presidir um comitê com participantes da FFCL (Faculdade de Filosofia, Ciências e Letras, da Universidade de São Paulo) e da ELSP (Escola Livre de Sociologia e Política). ${ }^{83}$

Bastide chamou para o grupo Florestan Fernandes. Ambos publicaram em 1955, "Relações raciais entre negros e brancos em São Paulo" ${ }^{84}$, onde:

Florestan Fernandes não só faz uma descrição e uma interpretação objetivas da situação da existência do negro e do mulato na emergência da sociedade de classes e da ordem social competitiva, como também revela as potencialidades do despertar da consciência de luta por parte das vítimas do preconceito de cor e da estratificação social subordinada ao critério da raça e de superação das desigualdades raciais e da ausência de uma autêntica democracia racial. ${ }^{85}$

Os estudos da UNESCO não só mostraram não existir no Brasil a democracia racial, como mostraram existir um preconceito racial arraigado ao preconceito de classe, um alimentando o outro:

\footnotetext{
${ }^{82}$ ANDREWS, George Reid. "Democracia racial brasileira 1900-1990: um contraponto americano". Estudos Avançados. № 30 (11), maio/agosto 1997, p. 101.

${ }^{83}$ MAIO, Marcos Chor. Op. cit. p. 149.

${ }^{84}$ BASTIDE, Roger \& FERNANDES, Florestan. Relações Raciais entre negros e brancos em São Paulo. São Paulo: Anhembi, 1955.

${ }^{85}$ SOARES, Eliane Veras, et al. O dilema racial brasileiro: de Roger Bastide a Florestan Fernandes ou da explicação teórica à proposição política. (consulta na internet, endereço www.revistas.ufg.br/index.php/fchf/article/view/551/474.pdf, acesso em 25/09/2007), p. 44.
} 
Assim, cria-se um círculo vicioso: a modificação das atitudes dos brancos sobre os negros e os mestiços depende da alteração da posição social destes; de outro lado, porém, a perpetuação de atitudes desfavoráveis aos negros e aos mestiços tende a limitar o acesso deles, pelo menos em condições de igualdade com os brancos, às probabilidades de atuação social asseguradas pelo regime de classes, em cada um de seus níveis sociais. ${ }^{86}$

Em "Relações raciais entre negros e brancos em São Paulo", foi incluído um importante estudo "Preconceito racial de marca e preconceito racial de origem", de Oracy Nogueira. Neste estudo Nogueira distingue o preconceito racial de marca, presente no Brasil, referente ao fenótipo do indivíduo, do preconceito racial de origem, presente nos EUA, referente à ascendência, ou seja, mesmo que o indivíduo tenha aparência branca, predominará sua ancestralidade negra, como fonte de preconceito.

$\mathrm{Na}$ continuidade dos trabalhos da Escola Paulista de Sociologia, Fernando Henrique Cardoso e Octavio Ianni desenvolveram um estudo sobre as relações entre brancos e negros em Florianópolis, intitulado "Cor e Mobilidade Social em Florianópolis". Conforme o estudo, sendo Desterro (antigo nome de Florianópolis) "uma comunidade pobre, a escravidão não foi extensa e houve coexistência do trabalho livre com o trabalho escravo.(...) A discriminação legal e política não diferia da existente nas outras áreas do Império." ${ }^{87} \mathrm{E}$, "se na lavoura o açoriano também trabalhava, no serviço doméstico os misteres mais árduos eram exercidos pelos escravos. ${ }^{188}$

A abolição não implicou em nenhuma ascensão social do grupo negro, não acarretando a desorganização imediata da vida econômica do ex-escravo. "Não houve, pois, de maneira imediata, nenhum fator que contribuísse para alterar as avaliações sociais dos negros, mantidas pelos brancos. À medida que estes transferiram para o negro avaliações desfavoráveis elaboradas para justificar a escravidão, estas não deixaram de existir depois da Abolição." ${ }^{89} \mathrm{~A}$ conclusão é que em Florianópolis a relação entre brancos (mesmo pobres) e negros, era de dominação, sendo os primeiros os dominadores, e os segundos os dominados. ${ }^{90}$

\footnotetext{
${ }^{86}$ FERNANDES, Florestan. Apud SOARES, Eliane Veras, ibdem, p. 42.

${ }^{87}$ CARDOSO, Fernando Henrique, IANNI, Octavio. Cor e mobilidade social em Florianópolis. São Paulo: Companhia Editora Nacional, 1960, p. 122.

${ }^{88}$ Idem, p. 124

${ }^{89}$ Idem, p. 137

${ }^{90}$ Idem, p. 151
} 
Nos estudos seguintes, Florestan Fernandes levanta pontos importantes. Ele fala da desigualdade de oportunidades entre brancos e negros, enfatiza que a pretendida democracia racial brasileira é um mito, e que ela, além de não se configurar na realidade, prejudica o negro, no sentido de não ajudá-lo a tomar consciência da sua situação:

É uma confusão, sob muitos aspectos farisáica, pretender que o negro e o mulato contem com igualdade de oportunidades diante do branco, em termos de renda, de prestígio social e de poder. (...) Os resultados da investigação que fiz, em colaboração com o Professor Roger Bastide, demonstram que essa propalada 'democracia racial' não passa, infelizmente, de um mito social. É um mito criado pela maioria e tendo em vista os interesses sociais e os valores morais dessa maioria; ele não ajuda o 'branco' no sentido de obrigá-lo a diminuir as formas existentes de resistência à ascensão social do 'negro'; nem ajuda o 'negro' a tomar consciência realista da situação e a lutar para modificá-la. ${ }^{91}$

$\mathrm{Na}$ verdade o mito da democracia racial serviu para:

generalizar a consciência falsa da realidade racial, suscitando todo um elenco de convicções etnocêntricas: $1^{\circ}$ ) a idéia de que o 'negro não tem problemas no Brasil; $2^{\circ}$ ) a idéia de que, pela própria índole do Povo Brasileiro, 'não existem distinções raciais entre nós'; $3^{\circ}$ ) a idéia de que as oportunidades de acumulação de riqueza, de prestígio social e de poder foram indistinta e igualmente acessíveis a todos, durante a expansão urbana e industrial de São Paulo; $5^{\circ}$ ) a idéia de que não existe, nunca existiu, nem existirá, outro problema de justiça social com referência ao 'negro', excetuando-se o que foi resolvido pela revogação do estatuto servil e pela universalização da cidadania. ${ }^{92}$

Quanto ao tipo de preconceito existente no Brasil Florestan diz que no Brasil existe o preconceito de ter preconceito ${ }^{93}$, ou seja, mostrar preconceito seria algo degradante para o indivíduo preconceituoso, o que requer que ele aja com certo decoro. Porém, embora se combata a idéia de que no Brasil existe preconceito, nada é feito para mudar a situação dos negros, e o tratamento que lhes é conferido, continua sendo discriminatório.

Para Florestan, a discriminação racial existente é uma persistência do passado, na mentalidade do branco e do negro, nos seus ajustamentos à vida prática e na organização das

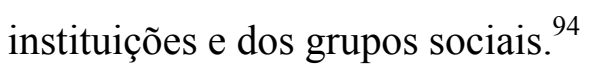

\footnotetext{
${ }^{91}$ FERNANDES, Florestan. O negro no mundo dos brancos. São Paulo: Difusão Européia do Livro, 1972, p. 40-41.

${ }^{92}$ FERNANDES, Florestan. A integração do negro na sociedade de classses. São Paulo: Ática, 1978, vol. 1 p. 256.

${ }^{93}$ FERNANDES, Florestan. O negro no mundo dos brancos. São Paulo: Difusão Européia do Livro, 1972, p. 42.

${ }^{94}$ Ibdem, p. 43
} 
Segundo o autor: "foi preciso quase três quartos de século para que o negro e mulato encontrassem, em São Paulo, perspectivas comparáveis àquelas com que se defrontaram os imigrantes e seus descendentes. ${ }^{.95}$ Ou seja, essa persistência do passado nas relações raciais fez com que o desenvolvimento sócio-econômico não beneficiasse os negros. $\mathrm{O}$ desenvolvimento sócio-econômico:

foi evidentemente insuficiente, até hoje, para promover o reajustamento da ordem racial herdada do passado aos requisitos da sociedade de classes. (...) É que os homens e as sociedades que eles formam nem sempre se modernizam por inteiro. Às vezes, elementos e fatores arcaicos continuam a existir e a operar além de sua era histórica, exercendo influências negativas na evolução da personalidade, da cultura e da própria sociedade. ${ }^{96}$

Para Florestan a cidade de São Paulo transformou-se urbana e economicamente, mas ficou presa ao passado quanto às relações raciais. Florestan incita os próprios negros a se conscientizarem e tentarem mudar a situação de forma organizada:

(...) é do próprio negro que deveria partir a resposta inicial ao desafio imposto pelo dilema racial brasileiro. Ele precisa mobilizar-se para defender alvos imediatos: uma participação mais eqüitativa nos proventos da ordem social competitiva; e para visar alvos remotos: a implantação de uma autêntica democracia racial na comunidade. ${ }^{97}$

Carlos Hasenbalg no seu estudo "Discriminação e desigualdades raciais no Brasil" critica a visão de que as relações raciais sejam resultado de uma "inércia histórica" do passado escravista, e, de que, "visto que esses padrões tradicionais não são funcionalmente exigidos pela nova estrutura social, eles deverão se atrofiar" ${ }^{98}$. Para Hasenbalg:

(a) a discriminação e preconceitos raciais não são mantidos intactos após a abolição, mas, pelo contrário, adquirem novos significados e funções dentro das novas estruturas e (b) as práticas racistas do grupo dominante branco que perpetuam a subordinação dos negros não são meros arcaísmos do passado, mas estão funcionalmente relacionados aos benefícios materiais e simbólicos que o grupo branco obtém da desqualificação competitiva dos não brancos. ${ }^{99}$

\footnotetext{
${ }_{95}^{95}$ Ibdem, p. 44

${ }^{96}$ Ibdem, p. 104-105

${ }^{97}$ Ibdem, p.107

${ }^{98}$ HASENBALG, Carlos Alfredo. Discriminação e desigualdades raciais no Brasil. Rio de Janeiro: Edições Graal, 1979, p. 85.

${ }^{99}$ Idem, p.85.
} 
No mesmo estudo Hasenbalg analisa uma amostra de brancos e não-brancos de seis estados do centro-sul do Brasil, quanto às variáveis educação, ocupação e renda, em termos de mudanças de posição na estrutura de classes. A conclusão é de que, "não só os não-brancos provêm desproporcionalmente dos níveis ocupacionais mais baixos, como também, controlando pela origem social, têm menores chances de mobilidade social ascendente". ${ }^{100}$

Os estudos dos pesquisadores citados contribuíram para mostrar que a democracia racial era na verdade um mito, e forneceram arcabouço analítico para embasar os movimentos negros que se seguiram.

\subsubsection{Pesquisas quantitativas}

Dados estatísticos de órgãos federais como IPEA (Instituto de Pesquisa Econômica Aplicada) mostram as desigualdades raciais e contribuem para justificar a necessidade de ações afirmativas para a população negra. Conforme Carvalho, os pesquisadores do IPEA, baseados em séries históricas e cruzando sistematicamente a marca racial com indicadores de renda, emprego, escolaridade, classe, idade, situação familiar e região, chegaram a conclusão irrefutável de que no Brasil a condição racial é sistematicamente fator de privilégio e vantagem para os brancos e desvantagem e exclusão para os pretos e pardos. ${ }^{101}$ Baseado em pesquisas oficiais de 2001 e 2002, Carvalho compila os seguintes números:

- A população do Brasil é de aproximadamente 180 milhões de pessoas; e $47 \%$ da população brasileira ( 84,6 milhões) são pessoas negras ( $7 \%$ de pretos e $40 \%$ de pardos).

- 25 milhões de seres humanos no Brasil vivem abaixo da linha de pobreza, condição definida como aqueles que não consomem o nível mínimo de calorias recomendado pela Organização das Nações Unidas (ONU). Desses, 25 milhões, 70\% são negros.

- 58 milhões de brasileiros vivem na pobreza (um mínimo de 200 reais por mês); desses, $63 \%$ são negros.

A primeira conclusão que tiramos desses dados é que a pobreza no Brasil tem em geral a cor negra. Mais do que isso, mesmos entre os pobres e miseráveis brasileiros, há os que são mais miseráveis ainda: os negros. Na distribuição da renda, o quadro se repete: dos $10 \%$ mais pobres, $70 \%$ são negros e $30 \%$ são brancos; enquanto dos $10 \%$ mais ricos, $85 \%$ são brancos e $15 \%$ são negros.

\footnotetext{
${ }^{100}$ Idem, p. 207.

101 CARVALHO, José Jorge de. Inclusão Étnica e Racial no Brasil - a questão das cotas no ensino superior. São Paulo: Attar, 2006, p. 26.
} 
Simetricamente então, assim como há um enegrecimento social da pobreza, há um evidente embranquecimento da riqueza. ${ }^{102}$

Carvalho diz que as diferenças raciais incidem sobre todas as fases da vida dos brasileiros:

- Na faixa do nascimento até os 6 anos, a pobreza atinge 51\% das crianças brasileiras, contudo, o índice de pobreza é muito menor entre as crianças brancas (38\%) que entre as negras, das quais $65 \%$ são pobres.

- Para cada 100 crianças brancas em situação de pobreza existem 170 crianças negras em idêntica condição.

- Entre 7 e 14 anos, o percentual de pobres entre os brancos é de 33\%, enquanto entre os negros é de $61 \%$.

- Entre 15 e 24 anos, vivem na pobreza $47 \%$ dos negros e $22 \%$ dos brancos.

Esses números reafirmam que os negros não conseguem recuperar a desvantagem com que nasceram, nem na adolescência, nem na fase adulta: sua desvantagem é crônica. ${ }^{103}$

Para demonstrar que a diferença entre negros e brancos não decorre apenas da renda, mas também da cor, os pesquisadores do IPEA observaram crianças de 11 a 14 anos, do sexo masculino, pertencentes ao grupo dos $25 \%$ mais pobres. Entre os meninos brancos desse grupo, 44,3\% estão cursando a segunda fase do primeiro grau (quinta a oitava série), enquanto os negros do mesmo grupo, apenas $27 \%$ cursam essa fase dos estudos. A conclusão é clara: ser negro no Brasil é ter menos acesso à educação que os brancos. E mais: a desigualdade entre crianças brancas e negras só tende a crescer na vida adulta. As causas são previsíveis - mais pobres, entram mais cedo no mercado de trabalho e se preparam menos, o que os confina às posições inferiores na sociedade e das quais não têm como sair. ${ }^{104}$

Quanto às diferenças educacionais entre brancos e negros, vejamos outros números do IPEA:

- 8,3\% dos brancos com mais de 15 anos são analfabetos, enquanto $20 \%$ dos negros com mais de 15 anos são analfabetos;

- 26,4\% dos brancos adultos são analfabetos funcionais, enquanto 46,9\% dos negros adultos são analfabetos funcionais;

- 57\% dos adultos brancos não completaram o ensino fundamental, enquanto 75,3\% dos adultos negros não completaram o ensino fundamental;

- 63\% dos jovens brancos de 18 a 23 anos não completaram o ensino médio, enquanto $84 \%$ dos jovens negros não completaram o ensino médio.

\footnotetext{
${ }^{102}$ Idem, p. 27.

${ }^{103}$ Ibdem, p. 28

${ }^{104}$ Ibdem, p. 28
} 
Somente esses dados já mostram que a melhoria universalista no ensino básico não resolverá o problema da desvantagem dos negros, que é crônica. Já no ensino médio, a distância entre brancos e negros cresce cada vez mais:

- $12,9 \%$ dos brancos completaram o ensino médio, enquanto apenas $3,3 \%$ dos negros completaram o ensino médio. ${ }^{105}$

Segundo relatório do PNUD (Programa das Nações Unidas para o Desenvolvimento) divulgado em 18-11-2005 os negros no Brasil estão em situação desfavorável. Diz o estudo que "os dados apenas corroboram o que está a vista de qualquer observador: quanto mais se avança rumo ao topo das hierarquias de poder, mais a sociedade brasileira se torna branca" ${ }^{106}$. Conforme o estudo, no que tange aos cargos eletivos, os negros têm sido sub-representados. Nunca tivemos um presidente negro, embora sobre um ou outro possa pairar dúvida sobre a mestiçagem. "Ainda que sem dispor de uma investigação rigorosa sobre o fenótipo dos governadores ao longo da história republicana do país, pode-se concluir pela subrepresentação dos negros nessa posição. O mesmo ocorre em relação aos prefeitos. Na história política recente, há poucos exemplos de pessoas negras que comandaram o executivo municipal." ${ }^{107}$ No legislativo, considerando o cargo de senador, de acordo com fotografias, dos 1055 cidadãos que ocuparam a posição, identificam-se pouquíssimos homens negros, e mais raramente, mulheres negras. Quanto ao cargo de deputado federal, os dados disponíveis indicam que houve 4 deputados federais negros de 1983 a 1987; 10 de 1987 a 1991; 16 de 1991 a 1995; e 15 de 1995 a 1999. Em relação ao Poder Judiciário, entre os juízes e desembargadores federais, $7 \%$ se declaram pretos ou pardos, sendo que $14 \%$ dos bacharelados se declaram negros. Quanto aos promotores, defensores públicos os negros representam 12\%, o que mostra uma pequena sub-representação, porém "é digno de nota o fato de que não há na amostra do Censo um só registro de promotor ou defensor público federal declarado preto: todos se declaram pardos" ${ }^{108}$.

\footnotetext{
${ }^{105}$ Ibdem, p. 29.

106 PROGRAMA DAS NAÇÕES UNIDAS PARA O DESENVOLVIMENTO (PNUD). Relatório de Desenvolvimento Humano - 2005. Racismo, pobreza e violência Brasil . (consulta na internet, endereço: www.pnud.org.br/rdh ), p.52

${ }^{107}$ Idem, p.47

${ }^{108}$ Idem, p.48
} 
Quanto ao IDH, (Índice de Desenvolvimento Humano, elaborado pela ONU) ${ }^{109}$, o Brasil em 2005 ocupava o $73^{\circ}$ lugar no ranking ${ }^{110}$. Em relação a esse estudo de 2005, se os brancos e negros formassem países diferentes, a distância entre eles seria de 61 posições: o Brasil branco ficaria em $44^{\circ}$ lugar e o Brasil negro ficaria em $105^{\circ}$ lugar. A diferença entre o desenvolvimento humano da população branca e o da população negra no Brasil está ligada sobretudo à renda. Os negros representam quase $44,7 \%$ da população brasileira, mas seus rendimentos correspondem a $26 \%$ do total apropriado pelas famílias brasileiras. "Embora homens e mulheres negros representem $44,7 \%$ da população brasileira, segundo dados do Censo 2000, publicados no portal do IBGE, sua participação chega a $70 \%$ entre os $10 \%$ mais pobres, a medida que se avança em direção aos estratos mais altos, sua presença diminui, ate atingir apenas $16 \%$ do último estrato (os $10 \%$ mais ricos) - situação que permaneceu praticamente inalterada ao longo dos anos 1990. Além disso, em todas as faixas, sem exceção, o rendimento médio dos brancos é superior ao dos negros. Os dados da Pesquisa Nacional por Amostra de Domicílio de 1999 revelavam que o Brasil branco era 2,5 vezes mais rico que o Brasil negro." ${ }^{111}$

Em relação à violência, o estudo aponta que o perfil das principais vítimas de violência é: negro, jovem, de sexo masculino e solteiro, sendo os negros as principais vítimas de violência policial no Brasil. ${ }^{112}$

De 1991 a 2000, a proporção de jovens brancos brasileiros (18 a 24 anos) matriculados na universidade cresceu de $7 \%$ para $11,7 \%$, enquanto o percentual de jovens negros matriculados no ensino superior variou de $1,5 \%$ a $2,5 \%$. Nota-se que apesar do crescimento a disparidade se manteve. Entre os adultos a porcentagem de negros com grau universitário em 2001 era de $2,5 \%$, e a dos brancos $10,2 \% .{ }^{113}$

A seguir mais dados sobre a população negra no ensino superior. Lopes utilizou informações dos resultados do Exame Nacional de Cursos realizado pelo MEC e conhecido

\footnotetext{
${ }^{109}$ O IDH mede o desenvolvimento humano dos países, considerando a expectativa de vida, a alfabetização e o PIB per capita.

${ }^{110}$ No ano de 2007 o IDH subiu, elevando o país para a $70^{\mathrm{a}}$ posição, $\operatorname{com}$ IDH $=0,8$

${ }^{111}$ PNUD. Relatório de Desenvolvimento Humano - 2005. op. cit. p. 60

${ }^{112}$ Idem, p. 87

${ }^{113}$ Idem, p.70
} 
como "Provão", referente ao ano de 2001. De acordo com o estudo, em relação aos que concluíram o ensino superior em 2001, 77,8\% eram brancos, 2,7\% pretos e 16,4\% pardos ${ }^{114}$, configurando, assim, uma sub-representação dos afro-descendentes. Quanto a renda familiar dos concluintes, somando as rendas familiares mensais que vão até R\$1.800,00, encontramos o percentual de 45,3\% nos brancos, $72,4 \%$ nos pretos e $65 \%$ nos pardos. Quando a renda mensal familiar está acima de R\$ 9.000,00, temos 5,1\% de brancos nessa faixa, 1,1\% dos negros e $1,6 \%$ dos pardos. Notamos que os afro-descendentes concentram-se na faixa de renda familiar de menor poder aquisitivo, enquanto que na faixa de maior valor, concentram-se os brancos. Os cursos onde se concentraram o maior número de formandos pretos e pardos são: Matemática, Letras, Pedagogia, Química, Física, seguidos do curso de Biologia. Os cursos que concentram menor número de pretos são Odontologia 0,6\%, Medicina 0,9\%, Medicina Veterinária 1,0\%, Farmácia 1,1\%, Administração 1,06\%, Direito, Psicologia e Engenharia Civil 1,8\%. Os cursos que concentram o menor número de pardos são; Odontologia 8,2\%, Medicina Veterinária 9,6\%, Engenharia Mecânica 10,9\%, Direito 11,3\%, Psicologia 11,5\% e Farmácia $11,8 \%{ }^{115}$ Vemos que os afro-descendentes estão mais concentrados nos cursos de menor prestígio, sendo mais sub-representados nos cursos de maior prestígio, que são os mais concorridos.

Conforme estudo do Instituto Ethos e do Ibope, em 2007, sobre as 500 maiores empresas do país, os negros detêm apenas $25,1 \%$ das vagas do quadro funcional. $\mathrm{O}$ afunilamento hierárquico é evidente:

Subindo na escala hierárquica, sua participação cai para $17,4 \%$ na supervisão, mantendo-se na mesma proporção (17\%) na gerência. Já no quadro executivo sua presença cai para 3,5\%. (...) A situação é ainda pior para as mulheres negras, que têm presença de 7,4\% no quadro funcional, $5,7 \%$ no quadro de supervisão, $3,9 \%$ na gerência e $0,26 \%$ no quadro executivo. Neste último nível, são, em valores absolutos, 4 negras ( 3 da cor parda e 1 da cor preta) num total de 1.528 diretores cuja cor ou raça foi informada. ${ }^{116}$

\footnotetext{
${ }^{114}$ LOPES, Ana Lúcia. Alunos negros-mestiços concluintes do Ensino Superior. In DURHAM, Eunice R.; BORI, Carolina M. (org). Seminário o negro no ensino superior. São Paulo: USP; NUPES, 2002. p. 19.

${ }^{115}$ Idem, p.24-25

${ }^{116}$ INSTITUTO ETHOS / IBOPE. Perfil Social, Racial e de Gênero das 500 maiores empresas do Brasil e suas ações afirmativas. Pesquisa 2007. Consulta na internet, endereço //ethos.org.br/_Uniethos/Documents/PesquisaDiversidade2007.pdf, acesso 01-10-2008.
} 
A situação da mulher negra realmente é a mais vulnerável. Conforme dados do IPEA 2006:

Os dados de rendimento médio da ocupação principal no mercado de trabalho capturam de forma evidente as desigualdades de gênero e raça. Como conseqüência das desigualdades educacionais, da segregação de mulheres e negros em postos de trabalho de menor qualidade e do próprio fenômeno social da discriminação, os rendimentos de homens e de brancos tendem a ser mais elevados do que o de mulheres negras. Com efeito, em 2006, os homens recebiam, em média, $\mathrm{R} \$ 885,6$ ao mês, enquanto as mulheres recebiam apenas $\mathrm{R} \$ 577,0$, o que equivale a cerca de $2 / 3$ do salário masculino. De forma ainda mais intensa, os negros recebiam cerca de metade do salário dos brancos, perfazendo $\mathrm{R} \$ 502,0$ em média por mês, contra $\mathrm{R} \$ 986,5$ dos brancos. Os dados evidenciam, mais uma vez, a dupla discriminação sofrida pelas mulheres negras no mercado de trabalho. Enquanto as mulheres brancas ganham, em média, $63 \%$ do que ganham homens brancos, as mulheres negras ganham $66 \%$ dos homens do mesmo grupo racial e apenas $32 \%$ do rendimento médio de homens brancos. ${ }^{117}$

Quanto ao emprego doméstico, predominam as empregadas domésticas negras:

Se se compara o total de mulheres brancas ocupadas em trabalho doméstico remunerado $(13,4 \% \mathrm{em}$ 1996 e 12,6\% em 2006) com o total de mulheres negras que desempenham essa mesma atividade ( $23 \%$ em 1993 e $21,7 \%$ em 2006) percebe-se que, mesmo havendo uma pequena queda em ambos os dados na década, persiste ainda o fato de que o trabalho doméstico remunerado no Brasil é majoritariamente desempenhado por mulheres negras. Este quadro inicial da situação do trabalho doméstico remunerado no Brasil revela muito dos padrões vigentes das desigualdades de gênero e raça, legados do modelo patriarcal e racista. ${ }^{118}$

Ainda como exemplo da desvantagem que a mulher negra sofre, observamos que a presença da mulher negra no mercado de modelos é reduzidíssima. Rojane Fradique, modelo da Elite Models, conta: “É mais difícil para uma modelo negra estourar porque o mercado é bem mais limitado. Dizem que não existe preconceito, mas isso é conversa”. Na Elite Models, são dez os negros, num universo de 300 modelos. A HDA Models existe há cinco anos e trabalha só com negros. "Infelizmente, a maior parte da população pobre no Brasil é negra. Acredito que muitos empresários não querem vincular seus produtos à figura de um negro porque, teoricamente, ele estará representando um grupo sem poder de compra", analisa Helder Dias, dono da HDA. (Folha de São Paulo, 20-11-2005, caderno Cotidiano).

Quanto à influência da mídia:

${ }^{117}$ IPEA - Retrato das desigualdades de gênero e raça. Brasília, 2008, p. 13. Consulta na internet, endereço www.ipea.gov.br/sites/000/2/destaque/Pesquisa_Retrato_das_Desigualdades.pdf, acesso em 26-11-2008.

${ }^{118}$ Idem, p. 10. 
Além de sua autoridade discursiva, a mídia tem papel central na produção de imagens, com a televisão, suas telenovelas e a publicidade. O padrão de estética é conhecido: branco, louro e de olhos azuis, ficando de fora a maioria do povo brasileiro. (...) Em 59 horas de programação em horário nobre das três maiores redes de televisão do país, os negros figuravam em apenas 39 dos comerciais. Somente em nove apareciam com fala e só em quatro tinham papel relevante (um se referia ao Centenário da Abolição e os outros três outros à indústria do entretenimento). Não só nos meios de comunicação desaparece o tratamento construtivo da questão racial, mas também no mundo literário. Uma pesquisa da Universidade de Brasília que analisa 258 romances brasileiros publicados entre 1990 e 2004 oferece resultados reveladores: 93,9\% dos autores são brancos. Dos 1245 personagens listados nesses romances, $79,8 \%$ são brancos, $7,9 \%$ são negros e $6,1 \%$ mestiços. No total, $73,5 \%$ dos personagens negros são pobres e 12,2\% deles, miseráveis. ${ }^{119}$

Para diminuir essas diferenças, o Relatório de Desenvolvimento Humano - Brasil 2005 (PNUD) afirma que são necessárias, além de políticas universalistas, medidas pontuais: "As políticas universais podem e devem ser complementadas por programas que atendam a públicos específicos, a fim de superar desvantagens e discriminações de natureza regional, racial, de gênero, de faixa etária, de nível de escolaridade ou outras situações especiais de vulnerabilidade." ${ }^{120}$

\subsection{Ações afirmativas e modalidades}

Conforme Carvalho, a Índia é o país com mais longa história de ações afirmativas no mundo. O criador do sistema de cotas foi o indiano Bhimaro Ramji Ambedkar, líder dos dalits, os intocáveis, casta mais inferior na Índia. Ambedkar conseguiu colocar, na Constituição da Índia independente, em 1948, as cotas para os dalits, nas instituições de ensino e no serviço público, como forma de compensar milênios de desigualdade. Até hoje a Índia mantém cotas para os intocáveis. ${ }^{121}$

A expressão ação afirmativa foi utilizada pela primeira vez (affirmative action) no governo do Presidente John F. Kennedy, na Executive Order n. 10 925, em 6 de março de 1961, nos contratos com o governo federal:

\footnotetext{
${ }^{119}$ PNUD - Relatório de Desenvolvimento Humano - 2005. op. cit., p.133

${ }^{120}$ PNUD - Relatório de Desenvolvimento Humano - 2005. op. cit., p.118

${ }^{121}$ CARVALHO, José Jorge de. Inclusão Étnica e Racial no Brasil - a questão das cotas no ensino superior. São Paulo: Attar, 2006, p. 184-185.
} 
SEÇÃO 301 [...] (1) o contratante não discriminará nenhum empregado ou candidato a emprego por causa de sua raça, credo, ou origem nacional. $\mathrm{O}$ contratante adotará ação afirmativa para garantir que os candidatos sejam empregados, e que os empregados sejam tratados durante o emprego, sem consideração para com sua raça, credo, cor ou origem nacional $\left[\ldots . . .{ }^{122}\right.$

Em 2 de julho de 1964 presidente Lyndon B. Johnson adotou medidas mais efetivas contra a discriminação, o Civil Right Act (Lei dos Direitos Civis), que proibia desde a segregação em lugares públicos até o discrímen no mercado de trabalho com base na raça, cor, sexo ou origem nacional do cidadão. Com a Executive Order n. 11 246, de 24 de setembro de 1965, ao exigir dos contratantes com o Governo Federal não só o fim das práticas discriminatórias, como também medidas favoráveis em relação as minorias raciais e étnicas, na área de recrutamento, contratação, salários, etc., o conceito de ação afirmativa se sedimentou. ${ }^{123}$

Vejamos algumas definições de ações afirmativas. Conforme Joaquim Benedito Barbosa Gomes:

As ações afirmativas podem ser definidas como um conjunto de políticas públicas e privadas de caráter compulsório, facultativo ou voluntário, concebidas com vistas ao combate à discriminação racial, de gênero, por deficiência física e de origem nacional, bem como mitigar os efeitos presentes da discriminação praticada no passado, tendo por objetivo a concretização do ideal de efetiva igualdade de acesso a bens fundamentais como educação e o emprego. ${ }^{124}$

O significado de ação afirmativa para Fogaça:

Ações afirmativas não significam a obtenção de privilégios mas, sim, a exigência de que o Estado tome atitudes objetivas diante de uma sociedade que escamoteia de múltiplas formas a discriminação racial. Não se trata de privilegiar os negros; ao contrário e exatamente em nome dos princípios democráticos e constitucionais, trata-se de oferecer alguma contraposição aos históricos privilégios dos brancos, abrindo espaço para uma maior participação dos negros. ${ }^{125}$

Sidney Madruga destaca como elementos conceituais das ações afirmativas:

${ }^{122}$ MADRUGA, Sidney. Discriminação Positiva: Ações Afirmativas na Realidade Brasileira. Brasília: Brasília Jurídica, 2005, p.66.

${ }^{123}$ Idem, p.67.

${ }^{124}$ GOMES, Joaquim B. Barbosa. "As ações afirmativas e os processos da igualdade efetiva". In: Seminário Internacional As Minorias e o Direito. Série Cadernos do CEJ, vol 24, p. 103. Brasília: Conselho da Justiça Federal, Centro de Estudos Judiciários, 2003.

${ }^{125}$ FOGAÇA, A. apud CANDAU, Vera Maria Ferrão. Universidade e diversidade cultural: alguns desafios a partir da experiência da PUC-Rio. In: PAIVA, Ângela Randolpho org. Ação Afirmativa na universidade: reflexão sobre experiências concretas Brasil - Estados Unidos. Rio de Janeiro: Editora PUC-Rio, 2004, p. 89. 
I. a compulsoriedade ou voluntariedade e a temporariedade, ou não, das medidas a serem adotadas por órgãos públicos ou privados

II. a concessão do benefício ou vantagem a determinados grupos sociais discriminados

III. a busca da igualdade de oportunidades e tratamento

IV. medidas direcionadas, em especial, à área da educação, da saúde e do emprego. ${ }^{126}$

Pelas definições acima, notamos que as ações afirmativas podem ser medidas estatais ou privadas, obrigatórias ou facultativas e visam a favorecer grupos que estão em desvantagem. Quanto ao caráter temporário, não se deve esperar que todos tipos de ação afirmativa sejam temporárias. Por exemplo, as cotas em universidades se justificam enquanto as desigualdades se mostrarem presentes, uma vez as oportunidades igualadas, as cotas devem ser suspensas. Há grupos, no entanto, que demandam maior tempo de implementação das ações afirmativas, se não perenemente. É o caso das comunidades indígenas e de quilombolas, "cujas especificações, sobretudo as diretamente relacionadas a sua identificação, saúde e habitat, requerem, por certo, o implemento de programas e políticas governamentais de caráter permanente". ${ }^{127}$ Acrescentemos a política de cotas nos concursos públicos para deficientes físicos, instituída na Constituição. É possível que tal grupo seja permanentemente protegido, dadas as circunstâncias de suas desvantagens.

As ações afirmativas têm triplo caráter: compensatório (compensar injustiças do passado), distributivo (melhor distribuição das oportunidades) e também preventivo, no sentido de se evitar futuros conflitos sociais, hoje latentes. Além disso, os beneficiários das ações afirmativas atuais, no futuro estarão numa condição social melhor, portanto seus filhos não precisarão mais de ações afirmativas.

\footnotetext{
${ }^{126}$ idem, p.63-64.

${ }^{127}$ MADRUGA, Sidney. Discriminação Positiva: Ações Afirmativas na Realidade Brasileira. Brasília: Brasília Jurídica, 2005, p. 60.
} 


\section{Modalidades}

Sem pretender esgotar as possibilidades, vejamos algumas modalidades de ação afirmativa.

\section{Cotas ou reserva de vagas.}

No sistema de cotas, uma dada porcentagem do número de vagas disponíveis é reservada para o grupo que se deseja favorecer. Por exemplo, consta na Constituição Federal no art. 37, inciso VIII: "a lei reservará percentual dos cargos e empregos públicos para as pessoas portadoras de deficiência e definirá os critérios de sua admissão”. Apesar de proteger ambos os sexos, este parágrafo procura estabelecer participação feminina maior na vida política do país, na qual as mulheres estão sub-representadas. Em relação às cotas nos estabelecimentos públicos de ensino superior, temos cotas para negros, índios e oriundos de escolas públicas em mais de 80 estabelecimentos públicos de ensino superior. Esses exemplos serão vistos mais adiante.

\section{Implantação de bônus.}

Neste sistema os pleiteantes recebem pontos, com vista a melhorar sua nota na competição. A Unicamp (Universidade de Campinas, Estado de São Paulo), no seu vestibular, oferece 30 pontos à Nota Padronizada de Opção (NPO) para candidatos que tenham cursado integralmente o ensino médio em escolas públicas. Desses, aqueles que se declararem negros ou indígenas terão direito ao acréscimo de mais 10 pontos à NPO.

\section{Preferências}

Nesse sistema, os candidatos concorrem em mesmas condições, mas no caso dos que obtêm os mesmos resultados, aqueles que pertencem às minorias que se pretende favorecer são 
admitidos. ${ }^{128}$ Outra forma de preferência é aquela que o Poder Público exerce quando da licitação para contratação de serviços, obras, compras, etc., dando preferência, sob determinados critérios, aos pretendentes que cumpram alguma meta de favorecimento às minorias, como por exemplo, ter uma porcentagem mínima de negros no seu quadro de funcionários.

\section{Cursos pré-vestibulares}

Os cursos pré-vestibulares para negros e carentes são iniciativas para ajudar esses candidatos a entrarem nas universidades. Exemplifiquemos com os cursos pré-vestibulares EDUCAFRO, destinados a negros e a candidatos carentes; o PVNC - Pré-vestibular para Negros e Carentes, no Rio de Janeiro; e o trabalho da CEASM, (Centro de Estudos e Ações Solidárias da Maré), no Rio de Janeiro.

\section{EDUCAFRO}

A EDUCAFRO - Educação e Cidadania de Afro-descendentes e Carentes, rede de cursinhos pré-vestibulares comunitários, atua nos Estados de São Paulo, Rio de Janeiro, Minas Gerais, Santa Catarina e o Distrito Federal. Sobre a missão da EDUCAFRO:

A EDUCAFRO tem a missão de promover a inclusão da população negra (em especial) e pobre (em geral), nas universidades públicas e particulares com bolsa de estudos, através do serviço de seus voluntários e voluntárias nos núcleos de pré-vestibular comunitários e setores da sua Sede Nacional, em forma de mutirão. No conjunto de suas atividades, a EDUCAFRO luta para que o Estado cumpra suas obrigações, através de políticas públicas e ações afirmativas na educação, voltadas para negros e pobres, promoção da diversidade étnica no mercado de trabalho, defesa dos direitos humanos, combate ao racismo e a todas as formas de discriminação. ${ }^{129}$

A EDUCAFRO é organizada da seguinte maneira: a coordenação nacional é feita pelos Frades Franciscanos, e uma equipe técnica composta por 16 funcionários e 25 voluntários, que

\footnotetext{
${ }^{128}$ BELlintani, Leila Pinheiro. Ação Afirmativa e os Princípios do Direito. Rio de Janeiro: Lúmen Júris, 2006 , p. 70

${ }^{129}$ Consulta na internet no endereço: www.educafro.org.br/ind_001_sms.asp, acesso em 06/10/08
} 
articulam os serviços da Sede Nacional, e dos 255 núcleos (unidades) de pré-vestibulares comunitários. Os coordenadores de cada núcleo e os professores são voluntários. A rede forma um "mutirão" de 2550 professores voluntários e 1270 coordenadores de núcleos. Esses núcleos funcionam em espaços cedidos por igrejas, associações comunitárias, escolas públicas, etc. ${ }^{130}$

\section{PVNC}

O PVNC, curso Pré-Vestibular para Negros e Carentes foi fundado em cinco de junho de 1993, com uma aula inaugural na Igreja da Matriz de São João do Meriti. Surgiu de um núcleo organizado por David Raimundo dos Santos, Antônio Dourado, Luciano de Santana Dias e Alexandre do Nascimento, que tinha por objetivo a capacitação de estudantes para concorrerem a 200 bolsas oferecidas pela PUC-SP e para concorrerem nos vestibulares das universidades públicas do Estado do Rio de Janeiro. O ano de 1994 foi um ano de crescimento e criação de novos núcleos. ${ }^{131}$

Em 1993 foi lançada a semente, mas 1994 foi o ano em que o PVNC começou a se constituir como um Movimento Social de Educação Popular. A questão do preconceito e da discriminação racial é sua principal preocupação, pois é uma barreira que coloca negros e negras em situação de desvantagem, além de contribuir bastante para as desigualdades sociais no Brasil ${ }^{132}$

Na organização do PVNC destacam-se os núcleos e a Assembléia Geral. Os núcleos são os cursos pré-vestibulares, os quais possuem coordenadores (as), professores (as) e alunos (as), estes últimos de famílias de baixa renda, preferencialmente negros e negras, que contribuem mensalmente com no máximo, $10 \%$ do salário mínimo vigente. Na Assembléia Geral participam todos integrantes do PVNC (coordenadores, professores, educandos e colaboradores) e são discutidas as várias questões e todos (as) têm direito a voz e voto em iguais condições. ${ }^{133}$

\footnotetext{
130 idem

${ }^{131}$ Consulta na internet no endereço: pvnc.sites.uol.com.br/historicopvnc.htm, acesso em 06/10/08

132 ibdem

${ }^{133}$ Consulta na internet no endereço: pvnc.sites.uol.com.br/organizacao.htm, acesso em 06/10/08
} 


\section{CEASM}

A CEASM - Centro de Estudos e Ações Solidárias da Maré - é uma ONG que surgiu a partir da iniciativa de um grupo de moradores que cresceram e/ou moraram durante muitos anos em alguma comunidade da Maré, maior favela do Rio de Janeiro. A percepção da Maré é de "um espaço globalmente miserável, violento e destituído de condições dignas de vida. Independentemente dos exageros dessa representação, é inegável o reconhecimento dessa localidade como um espaço proletarizado, com o predomínio das populações nordestina e negra em condições socioprofissionais subordinadas e com baixa escolaridade."134 O CEASM desenvolve atividades em diversas áreas, tais como: a) A Rede Educação; b) O laboratório de informática; c) A Rede Trabalho; d) O observatório Social da Maré; e) A Rede Cidadania; f) As oficinas culturais; e g) A Casa de Cultura da Maré. É na Rede Educação que encontramos o Curso Pré-vestibular - CPV MARÉ; também há na Rede Educação: o curso de preparação para o Ensino Médio, o Núcleo de Línguas da Maré, o Programa da Criança e a Biblioteca Popular da Maré. ${ }^{135}$

\section{Bolsas}

Instituto Rio Branco

Um exemplo de bolsa destinada especificamente para negros, é o programa "Bolsasprêmio de Vocação para a Diplomacia" anunciado em 14 de maio de 2002, pelo Ministério das Relações Exteriores ${ }^{136}$, com objetivo de conceder bolsas para que candidatos afrodescendentes custeassem os estudos preparatórios para o exame de ingresso no Instituto Rio Branco. O Programa de Ação Afirmativa conta com a participação do Ministério do Desenvolvimento Social e Combate à Fome, da Secretaria Especial dos Direitos Humanos, da

${ }^{134}$ SILVA, Jailson de Souza. As práticas 'afirmativas' do Centro de Estudos e Ações Solidárias da Maré CEASM.. In: PAIVA, Ângela Randolpho org. Ação Afirmativa na universidade: reflexão sobre experiências concretas Brasil - Estados Unidos. Rio de Janeiro: Editora PUC-Rio, 2004, p.193.

${ }^{135}$ Ibdem, p. 203

136 KAUFMANN, Roberta Fragoso Menezes. Ações afirmativas à brasileira: necessidade ou mito?. Porto Alegre: Livraria do Advogado, 2007., p. 269. 
Secretaria Especial de Políticas de Promoção da Igualdade Racial e da Fundação Cultural Palmares. Segundo o edital de 12 de dezembro de 2007, o Programa Bolsa-Prêmio de Vocação para a Diplomacia "tem como objetivo ampliar as oportunidades de acesso aos quadros do Ministério das Relações Exteriores e incentivar e apoiar o ingresso de afro-descendentes (negros) na Carreira Diplomática, mediante a concessão de bolsas-prêmio destinadas ao custeio de estudos preparatórios ao Concurso de Admissão à carreira de diplomata."

Segundo o mesmo edital, o valor total da Bolsa-Prêmio de Vocação para a Diplomacia é de R \$ 25.000,00, sendo desembolsado parceladamente entre março e dezembro de 2008. Uma vez conseguida a bolsa, o bolsista deverá se inscrever no primeiro Concurso de Admissão à Carreira de Diplomata que se realizar em 2009, sob pena de ter de devolver os recursos recebidos ao CNPq. A condição de afro-descendente (negro) é expressa por autodeclaração. Porém, na segunda etapa, um dos requisitos é uma entrevista técnica com valor de 100 pontos, sendo que 30 pontos são destinados à experiência pessoal do candidato como afro-descendente (negro) e ao conhecimento do Programa. Conforme edital de 16 de janeiro de 2007, do mesmo Instituto, foram contemplados com bolsas, 45 candidatos.

Até 2005, os resultados do programa foram os seguintes: quatro contemplados com bolsa lograram aprovação no Concurso de Admissão à Carreira Diplomática. Desses, dois já se encontram lotados na Secretaria de Estado das Relações Exteriores e dois cursam o Instituto Rio Branco. ${ }^{138}$

\section{PUC-Rio}

Segundo Candau, a Pontifícia Universidade Católica - Rio de Janeiro, PUC-Rio, é uma universidade sem fins lucrativos e reconhecida nacionalmente pela sua qualidade acadêmica e científica, e considerada de elite social. A PUC-Rio vem desenvolvendo, desde 1994, um programa com o objetivo de favorecer o acesso de estudantes de camadas populares, a maioria

${ }^{137}$ MINISTÉRIO DAS RELAÇÕES EXTERIORES - INSTITUTO RIO BRANCO E MINISTÉRIO DA CIÊNCIA E TECNOLOGIA - CONSELHO NACIONAL DE DESENVOLVIMENTO CIENTÍFICO E TECNOLÓGICO (CNPq). Programa de Ação Afirmativa do Instituto Rio Branco em 2007 - Bolsas-prêmio de Vocação para a Diplomacia. Edital de 12 de dezembro de 2007. Consulta na internet, endereço www.irbr.mre.gov.br, acesso em 02-10-2008.

${ }^{138}$ PRESIDÊNCIA DA REPÚBLICA - SEPPIR - Secretaria Especial de Políticas de Promoção da Igualdade Racial. Relatório de Gestão 2003-2006. P. 123. 
constituída por afro-descendentes. Esses alunos e alunas, uma vez aprovados nos exames vestibulares, candidatam-se a uma bolsa de "ação social", não reembolsável e que garante a gratuidade na universidade. Esses alunos e alunas também podem aceder, por meio do FESP (Fundo Emergencial de Solidariedade PUC-Rio), a outros apoios orientados a garantir alimentação, transporte e demais condições necessárias à freqüência à vida universitária. No ano de 2003 a universidade contava com cerca de 600 bolsistas, $(6 \%$ dos alunos de graduação), a maioria oriunda do PVNC e da EDUCAFRO. ${ }^{139}$

\section{UERJ}

A UERJ (Universidade Estadual do Rio de Janeiro) oferece o PAE (Programa de Apoio ao Estudante). A partir da matrícula, todos matriculados são considerados alunos da universidade, não havendo discriminação pela forma de ingresso (cotistas ou não cotistas), mas pelas necessidades que os alunos possuam. O PAE oferece para ingressantes cuja renda familiar seja menor que cinco salários mínimos, uma bolsa-auxílio, com duração de um ano. Essa bolsa não se confunde com as bolsas acadêmicas, as quais esses alunos podem concorrer a partir do $3^{\circ}$ semestre. ${ }^{140}$

\section{ProUni}

O ProUni, Programa Universidade para Todos, foi criado pelo governo federal em 2004 e institucionalizado pela lei $n^{0} 11.096$ em 13 de janeiro de 2005. Consiste na concessão de bolsas integrais ou parciais em cursos de graduação em instituições privadas. As instituições que aderem ao programa têm em contrapartida isenção de alguns tributos. Conforme Portal do MEC, "o ProUni reserva bolsas às pessoas com deficiência e aos autodeclarados indígenas, pardos ou pretos. O percentual de bolsas destinadas aos cotistas é igual àquele de cidadãos pretos, pardos e indígenas, em cada Estado, segundo o último censo do IBGE. Vale lembrar

\footnotetext{
${ }^{139}$ CANDAU, Vera Maria Ferrão. Universidade e diversidade cultural: alguns desafios a partir da experiência da PUC-Rio. In: PAIVA, Ângela Randolpho org. Ação Afirmativa na universidade: reflexão sobre experiências concretas Brasil - Estados Unidos. Rio de Janeiro: Editora PUC-Rio, 2004, p.94.

${ }^{140}$ Ibdem, p.193.
} 
que o candidato cotista também deve se enquadrar nos demais critérios de seleção do programa. ${ }^{141}$ Os candidatos são selecionados conforme as notas obtidas no ENEM (Exame Nacional do Ensino Médio). São oferecidas bolsas integrais, para estudantes que possuam renda familiar, por pessoa, de até um salário mínimo e meio (R\$622,50), e bolsas parciais de $50 \%$, para estudantes que possuam renda familiar, por pessoa, de até três salários mínimos (R\$ $1.245,00)$.

Dos exemplos de bolsas, os cursos pré-vestibulares e a "Bolsa-prêmio de Vocação para a Diplomacia", visam os meios para o beneficiário da ação afirmativa entrar na instituição desejada. No caso da "Bolsa-prêmio de Vocação para a Diplomacia", nada garante que a meta será alcançada, ou seja, aumentar a representatividade de negros na instituição. Comparativamente, as cotas visam a finalidade, ou seja, uma exame com cota de $20 \%$ das vagas para negros deverá atingir a meta desejada, ou seja, o ingresso de estudantes negros conforme estabelecido na cota. Já as bolsas da PUC-Rio (através da FESP) e da UERJ (PAE) visam a permanência do aluno na universidade.

\section{Indenizações.}

As reparações em dinheiro para grupos prejudicados historicamente podem ser objeto de ações afirmativas. A escravidão e o tráfico negreiro foram considerados crimes contra a humanidade pela Organização das Nações Unidas na Conferência de Durban em $2001^{142}$. Como tal, tornou-se crime imprescritível. A indenização esteve em pauta. Segundo Condoleezza Rice, secretária de Estado dos EUA, os negros americanos não devem receber indenizações pelo passado escravagista:

É melhor olharmos para frente em vez de apontar culpados no passado. Muitos países africanos queriam reparações por quase quatro séculos de escravidão e a declaração final da conferência ficou restrita a essa demanda ${ }^{143}$.

\footnotetext{
${ }^{141}$ Consulta na internet, endereço //portal.mec.gov.br/prouni, acesso em 06/10/2008.

142 Conferência Mundial contra o Racismo, Discriminação Racial, Xenofobia e Intolerâncias Correlatas, organizada pelas Nações Unidas em Durban, África do Sul, em setembro de 2001.

${ }^{143}$ Consulta na internet, endereço www.patriciagalvao.org.br/novo/textos/midiaracismo.doc
} 
A questão da indenização abriu grandes polêmicas. Os países historicamente relacionados com a escravidão e ao colonialismo se recusaram a pedir desculpas, o que poderia levar ao reconhecimento de responsabilidades e legitimar pedidos de reparação. Os argumentos contra a indenização foram vários. Condenando-se países por crimes históricos, perguntava-se até quando seria preciso retroceder na História: chegar às Cruzadas, à Roma antiga, à crucificação de Jesus Cristo? Outro argumento é que na época esses fatos não eram crimes. Também argumentou-se que as gerações atuais não podem ser responsabilizadas por crimes cometidos pelos seus antepassados. Outro argumento é que a escravidão já era praticada na África e os chefes africanos teriam participado do comércio vendendo seus semelhantes. $^{144}$

No seu Projeto de Lei n. 3198, de 2000, o "Estatuto da Igualdade Racial”, o senador Paulo Paim - PT/RS - estabeleceu o direito à indenização aos descendentes afro-brasileiros:

DO DIREITO À INDENIZAÇÃO AOS DESCENDENTES AFRO-BRASILEIROS

Art. 14. O resgate da cidadania dos descendentes de africanos escravizados no Brasil se fará com providências educacionais, culturais e materiais referidas na presente lei.

Parágrafo $1^{\circ}$ : A União pagará, a título de reparação, a cada um dos descendentes de africanos escravizados no Brasil o valor equivalente a $\mathrm{R} \$ 102.000,00$ (cento e dois mil reais)

Parágrafo $2^{\circ}$ : Terão direito a este valor material todos os descendentes de africanos escravizados no Brasil nascidos até a data de publicação da presente lei ${ }^{145}$.

Em entrevista ao www.portalafro.com.br, em 05/02/2002, Paulo Paim disse:

"Se não for possível definir uma quantia em valores, que se implantem políticas compensatórias. Que se invista em educação, habitação, saneamento básico, emprego e salários dignos que beneficiem a comunidade negra. Dentro do estatuto temos um capítulo que trata da criação do FUNDO DE REPARACÃO para os 500 anos de escravidão dos africanos negros e seus descendentes neste país. Este fundo contará com verbas do

\footnotetext{
${ }^{144}$ SANÉ, Pierre. Reivindicações articuladas (e contestadas) de reparação dos crimes da História, a propósito da escravidão e do colonialismo, por ocasião da Conferência de Durban. Genebra: 2002. (consulta na internet, endereço www.unesco.org.br/publicacoes).

${ }^{145}$ Quanto ao Projeto de Lei do Senador Paulo Paim, o "Substitutivo Adotado Pela Comissão ao Projeto de Lei 3.198/00" - Institui o Estatuto da Igualdade Racial, de 3-12-2002, Senado Federal , não faz menção às indenizações
} 
ORÇAMENTO DA UNIÃO, as quais estarão à disposição para a implementação de políticas e projetos de interesse da comunidade negra".

Em 13 de maio de 2005, a vereadora do município de São Paulo, Claudete Alves da Silva Souza, entrou com uma representação no Ministério Público Federal, sob número 1.34.001.002546/2005-74 com o intuito de pedir indenização aos negros afro-brasileiros, pelos danos materiais e morais causados no processo de escravidão, nos atos de abolição e pósabolição. O pedido discorre sobre as razões que justificariam as indenizações e sugere o valor mínimo de R\$ 2000 000,00 (Dois milhões de reais). Em 29 de junho de 2005 ocorreu uma audiência pública no Ministério Público Federal ${ }^{146}$, com vários convidados da sociedade civil, ONGs, Movimento Negro e representantes do Estado, objetivando colher informações sobre o pedido. Após análises, em 03 de agosto de 2006 o Ministério Público Federal, através da Procuradoria Regional dos Direitos do Cidadão, manifestou-se quanto à ação coletiva proposta, concluindo por não acatar o pedido de indenização, sendo o principal motivo o econômico, conforme Suiama:

\begin{abstract}
Do ponto de vista econômico, o pagamento de R $\$ 2.076 .000,00$ a, por hipótese, 87.374.950 brasileiros, importaria no desembolso, pela União, de R \$ 181.390.396.200.000,00 (cento e oitenta e um trilhões, trezentos e noventa bilhões, trezentos e noventa e seis milhões e duzentos mil reais), sem incluir juros e correção monetária, ou o equivalente a 117 vezes o Produto Interno Bruto brasileiro do ano de 2003, que foi de $\mathrm{R} \$ 1,556$ trilhão de reais. Em outras palavras, se o país destinasse a soma de toda a riqueza produzida em seu território no intervalo de um ano para o pagamento da indenização pleiteada , levaria, num cálculo grosseiro, 117 anos para quitar o débito judicial pretendido pela representante. ${ }^{147}$
\end{abstract}

O Ministério Público Federal determinou providências tais como: a instauração de procedimento administrativo específico, com o escopo de apuração do cumprimento da Lei Federal $\mathrm{n}^{\circ} 10.639 / 03$, a qual tornou obrigatório o ensino sobre História e Cultura AfroBrasileira nos estabelecimentos de ensino fundamental e médio; recomendação à SEPPIR (Secretaria Especial de Políticas da Igualdade Racial) que publique, no sítio eletrônico informações atualizadas sobre todos os programas de ações afirmativas em execução pela Administração Pública Federal; expedição de ofício à SEPPIR e à Secretaria de Orçamento

\footnotetext{
${ }^{146}$ No auditório da Procuradoria da República em São Paulo, sito na rua Peixoto Gomide, 768, São Paulo -SP, térreo.

147 SUIAMA, Sergio Gardenghi. PRDC - Direito à igualdade material - acompanhamento das ações afirmativas em matéria racial desenvolvidas pela Administração Pública Federal. São Paulo: Ministério Público Federal, 2006 pg.15. Documento disponível no endereço citado na nota anterior.
} 
Federal do Ministério do Planejamento, Orçamento e Gestão para que apresentem no prazo de 30 dias planilha com todos programas em andamento na Administração Pública Federal relacionados à promoção da igualdade racial; expedição de ofício à Diretoria de Estudos Sociais do Instituto de Pesquisa Econômica Aplicada - IPEA, solicitando a avaliação das políticas sociais de promoção da igualdade racial em execução pela Administração Pública Federal. ${ }^{148}$

A principal dificuldade para o estabelecimento de indenizações é de cunho econômico e político. Poderia o Estado arcar com indenizações para $45 \%$ da população brasileira? Dependendo do valor, provavelmente não, como vimos no exemplo acima. Por isso essa modalidade de ação afirmativa pode mostrar-se inviável.

${ }^{148}$ Ibdem, p. 46-48 


\section{Constitucionalidade das ações afirmativas}

O direito à igualdade é um direito que surge na $1^{\mathrm{a}}$ geração de Direitos Humanos, a qual ocorre em fins do século XVIII. É a chamada "igualdade formal”, igualdade de todos perante a lei. A igualdade formal foi o tipo de igualdade que a França conquistou com a Revolução Francesa em 1789. A França antes da Revolução estava dividida em três classes: nobreza, clero e povo. A nobreza e o clero gozavam de diversos privilégios, sobretudo no que se referia ao tratamento legal, além disso, não pagavam impostos. Quem arcava com esse ônus era o povo. Com a igualdade formal, os privilégios do clero e da nobreza acabaram. Porém as desigualdades econômicas e sociais continuaram. A igualdade formal liga-se ao Estado Liberal, um Estado reduzido, que pouco interfere na vida sócio-econômica.

Com a Constituição do México (1917) e a Constituição alemã de Weimar (1919) marcase a $2^{\mathrm{a}}$ geração de Direitos Humanos, onde contrariando o liberalismo até então, surge o Estado Social, um Estado interventor na economia, garantidor de direitos sociais e econômicos. A intervenção do Estado busca a diminuição de desigualdades sócio-econômicas. Segundo Bonavides:

De todos os direitos fundamentais a igualdade é aquele que mais tem subido de importância no Direito Constitucional de nossos dias, sendo, como não poderia deixar de ser, o direito-chave, o direito-guardião do Estado social. ${ }^{149}$

Nesse sentido estamos falando da igualdade material ou substancial. Entende-se como igualdade material ou substancial um:

tratamento eqüânime e uniformizado de todos os seres humanos, bem como a sua equiparação no que diz respeito à possibilidade de concessão de oportunidades (...) as oportunidades, as chances devem ser oferecidas de forma igualitária para todos os cidadãos, na busca pela apropriação dos bens da cultura. ${ }^{150}$

\footnotetext{
${ }^{149}$ BONAVIDES, Paulo. Curso de Direito Constitucional. São Paulo: Malheiros Editores, 2007, p. 376.

${ }^{150}$ SILVA, Marcelo Amaral. Digressões acerca do princípio constitucional da igualdade. (consulta na internet, http://jus2.uol.com.br/doutrina/texto.asp?id=4143 em 17/12/2007)
} 
A questão da constitucionalidade das ações afirmativas baseia-se na utilização dos dois tipos de igualdade, a formal e a material. A igualdade formal (igualdade de todos perante a lei) está prevista no artigo $5^{\circ}$ da Constituição Federal, caput:

“Art $5^{\circ}$ Todos são iguais perante a lei, sem distinção de qualquer natureza..."

Esse preceito da constituição tornaria as ações afirmativas inconstitucionais, dado que elas consistem num tipo de discriminação, ainda que positiva. No entanto, a Constituição deve ser interpretada no seu contexto. Conforme Maliska:

A Constituição procurou se afastar de uma visão formalista e abstrata da realidade. Ela já nos seus primeiros artigos reconhece as desigualdades, a marginalidade, enfim, os problemas da sociedade brasileira e convoca a República para enfrentá-los. ${ }^{151}$

Conforme o $\operatorname{artigo~} 3^{\circ}$ da Constituição, incisos I, III e IV:

“Art. $3^{\circ}$ Constituem objetivos fundamentais da República Federativa do Brasil:

I- construir uma sociedade livre, justa e solidária;

(...)

III- erradicar a pobreza e a marginalização e reduzir as desigualdades sociais e regionais;

IV- promover o bem de todos, sem preconceitos de origem, raça, sexo, cor, idade e quaisquer outras formas de discriminação."

Os incisos mostram intenções de realizar a igualdade material, ou seja, a igualdade de oportunidades. O inciso I dita o objetivo de construir uma sociedade livre, justa e solidária. Uma sociedade não pode ser livre se as pessoas não têm possibilidades de realizar seus anseios, não pode ser justa se há disparidades sociais e econômicas, não pode ser solidária se não há correção das injustiças. Logo, para a concretização desses objetivos, justifica-se a busca pela igualdade material. O inciso III é expresso no sentido da realização da igualdade material, dizendo-nos ser objetivo da República a erradicação da pobreza e da marginalização

${ }^{151}$ MALISKA, Marcos Augusto. "Análise da constitucionalidade das cotas para negros em universidades públicas.” In: DUARTE, Evandro C. Piza, BERTÚLIO, Dora Lúcia de Lima e SILVA, Paulo Vinícius Baptista da (coords.). Cotas raciais no ensino superior. Curitiba: Juruá Editora, 2008, p. 63. 
e a redução das desigualdades sociais e regionais. O inciso IV também prima pela busca da igualdade material, ao intencionar a promoção do bem de todos e o repúdio à discriminação. A mera "igualdade perante à lei” não dá conta da realização desses objetivos prescritos na Constituição, pois permite disparidades flagrantes. É necessário, portanto, a busca pela igualdade material.

\section{Segundo Maliska:}

Uma Constituição que reconhece que há discriminação e desigualdade na sociedade não pode legitimar leis e políticas que tratam todos os cidadãos de igual forma, mantendo e reproduzindo a situação de desigualdade real. Não efetivar medidas compensatórias tendentes a reduzir as desigualdades revela-se inclusive omissão inconstitucional. ${ }^{152}$

A questão da desigualdade é tratada também no artigo 170, inciso VII, desta vez sendo a sua redução um princípio da Ordem Econômica:

"Art. 170. A ordem econômica, fundada na valorização do trabalho humano e na livre iniciativa, tem por fim assegurar a todos existência digna, conforme os ditames da justiça social, observados os seguintes princípios:

(...)

VII- redução das desigualdades regionais e sociais:"

$\mathrm{O}$ inciso I do artigo $5^{\circ}$ da Constituição diz que "homens e mulheres são iguais em direitos e obrigações". No entanto, ciente da desigualdade entre homens e mulheres no mercado de trabalho, o legislador estabeleceu, no artigo $7^{\circ}$, inciso $\mathrm{XX}$, que medidas sejam tomadas com vista à igualdade material:

"Art. $7^{\circ}$ São direitos dos trabalhadores urbanos e rurais, além de outros que visem à melhoria de sua condição social:

(...)

${ }^{152}$ MALISKA, Marcos Augusto. "Análise da constitucionalidade das cotas para negros em universidades públicas.” In: DUARTE, Evandro C. Piza, BERTÚLIO, Dora Lúcia de Lima e SILVA, Paulo Vinícius Baptista da (coords.). Cotas raciais no ensino superior. Curitiba: Juruá Editora, 2008, p. 64. 
$X X$ - proteção do mercado de trabalho da mulher, mediante incentivos especificos, nos termos da lei; "

Observamos que a intenção de proteger o mercado de trabalho da mulher através de incentivos específicos permite a aplicação de medidas como as ações afirmativas. Um exemplo de aplicação em lei do disposto nesse inciso é a lei 9.504/97, onde, o seu artigo 10, § $3^{\circ}$, estabelece uma cota mínima para candidaturas de cada sexo:

"§ $3^{\circ}($...) cada partido ou coligação deverá reservar o mínimo de trinta por cento e o máximo de setenta por cento para candidaturas de cada sexo."

Embora a cota mínima de 30\% sirva para homens e mulheres, a lei busca a inserção das mulheres no quadro político, por serem elas historicamente excluídas.

Um exemplo na Constituição da prescrição de ações afirmativas, na modalidade cotas, é o inciso VIII do artigo 37, referindo-se aos deficientes físicos:

“Art. 37 (...)

VIII- a lei reservará percentual dos cargos e empregos públicos para as pessoas portadoras de deficiência e definirá os critérios de sua admissão;"

Notamos por esses incisos citados da Constituição, que ela prima pela busca da igualdade material, indicando uma postura ativa para sua concretização. Nos dizeres de Gomes:

Esta, portanto, é a concepção moderna e dinâmica do princípio constitucional da igualdade, a que conclama o Estado a deixar de lado a passividade, a renunciar à sua suposta neutralidade e a adotar um comportamento ativo, positivo, afirmativo, quase militante, na busca da concretização da igualdade substancial. ${ }^{153}$

153 GOMES, Joaquim Barbosa. "O debate constitucional sobre ações afirmativas" In: SANTOS, Renato Emerson do; LOBATO, Fátima (orgs.) Ações afirmativas: políticas públicas contra as desigualdades raciais. Rio de Janeiro: DP \& A, 2003, p. 42. 
A questão das ações afirmativas ultrapassa o Direito Interno e envolve o Direito Internacional. A Convenção sobre a Eliminação de Todas as Formas de Discriminação Racial (1965) prevê a utilização de ação afirmativa, no artigo $1^{\circ}, \S 4^{\text {o: }}$

“Art. $1^{\circ}(\ldots)$

4. Medidas especiais tomadas com o objetivo precípuo de assegurar, de forma conveniente, o progresso de certos grupos sociais ou étnicos ou de indivíduos que necessitem de proteção para poderem gozar e exercitar os direitos humanos e as liberdades fundamentais em igualdade de condições, não serão consideradas medidas de discriminação racial, desde que não conduzam à manutenção de direitos separados para diferentes grupos raciais e não prossigam após terem sido atingidos os seus objetivos."

Os parágrafos $1^{\circ}$ e $2^{\circ}$ do artigo $5^{\circ}$ da Constituição Federal versam sobre a implementação dos direitos e garantias fundamentais:

“Art. $5^{\circ}(\ldots)$

$\S 1^{\circ}$ As normas definidoras dos direitos e garantias fundamentais têm aplicação imediata.

$\S 2^{\circ}$ Os direitos e garantias expressos nesta Constituição não excluem outros decorrentes do regime e dos princípios por ela adotados, ou dos tratados internacionais em que a República Federativa do Brasil seja parte."

\section{Conforme Gomes:}

Como resultado da conjugação do $\S 1^{\circ}$ com o $\S 2^{\circ}$ do art. $5^{\circ}$ do texto constitucional, uma interpretação sistemática da Constituição nos conduz à constatação de que estamos diante de normas da mais alta relevância para a proteção dos direitos humanos (e, conseqüentemente, dos direitos das minorias) no Brasil, quais sejam: os tratados internacionais de direitos humanos, que, segundo o dispositivo citado, têm aplicação imediata no território brasileiro, necessitando apenas de ratificação. ${ }^{154}$

Logo, conforme os parágrafos $1^{\mathrm{o}}$ e $2^{\circ}$ do artigo $5^{\circ}$ da Constituição e os dizeres de Gomes, que confirmam a aplicação imediata dos tratados internacionais ratificados pelo Brasil, e como

${ }^{154}$ Ibdem, p. 48. 
o Brasil ratificou a Convenção sobre a Eliminação de Todas as Formas de Discriminação Racial em 27/03/1968, podemos concluir que o Direito Internacional dá respaldo à aplicação de ações afirmativas para negros no Brasil, com a ressalva, apenas, da sua temporalidade, ou seja, sua utilização enquanto os efeitos perniciosos da discriminação persistirem.

É importante mencionar que a Convenção sobre a Eliminação de Todas as Formas de Discriminação contra a Mulher (1979), ratificada pelo Brasil em 01/02/1984, também prevê a utilização de ações afirmativas. Conforme seu artigo $4^{\circ}, \S 1^{\circ}$ :

“A adoção, pelos Estados Partes, de medidas especiais de caráter temporário visando acelerar a vigência de uma igualdade de fato entre homens e mulheres não será considerada discriminação, tal como definido nesta Convenção ${ }^{155}$, mas de nenhuma maneira implicará, como conseqüencia, na manutenção de normas desiguais ou distintas; essas medidas deverão ser postas de lado quando os objetivos de igualdade de oportunidade e tratamento tiverem sido atingidos. "

Mais uma vez notamos a ressalva da temporalidade da ação afirmativa, mas o interessante é que a conjunção das ações afirmativas acima mencionadas, para a pessoa negra e mulher, implica na proteção de um grupo específico, o de mulheres negras, grupo mais vulnerável socialmente, conforme dados estatísticos.

Resumindo, as ações afirmativas para a população negra têm respaldo jurídico na própria Constituição, a qual busca a concretização da igualdade material e têm respaldo no Direito Internacional, com os exemplos das Convenções citadas acima. Conforme Gomes:

É, portanto, amplo e diversificado o respaldo jurídico às medidas afirmativas que o Estado brasileiro resolva empreender no sentido de resolver esse que talvez seja o mais grave de todos os nossos problemas sociais - o alijamento e a marginalização do negro na sociedade brasileira. ${ }^{156}$

\footnotetext{
${ }^{155}$ A definição de discriminação contra as mulheres segundo a Convenção é a seguinte: "Para fins da presente Convenção, a expressão 'discriminação contra as mulheres' significa toda distinção, exclusão ou restrição fundada no sexo e que tenha por objetivo ou conseqüência prejudicar ou destruir o reconhecimento, gozo ou exercício pelas mulheres, independentemente do seu estado civil, com base na igualdade dos homens e das mulheres, dos direitos humanos e liberdades fundamentais nos campos político, econômico, social, cultural e civil ou em qualquer outro campo."

${ }^{156}$ GOMES, Joaquim Barbosa. Op. cit., p. 50.
} 
Uma decisão relevante para a constitucionalidade das ações afirmativas é a do relator Ministro Carlos Britto, do Supremo Tribunal Federal, na ADI 3330-1 DF, cujo requerente é a Confederação Nacional dos Estabelecimentos de Ensino, CONFENEN, contra ato do Presidente da República, especificamente a Medida Provisória 213/04, já convertida em Lei no 11096/2005, que institui o PROUNI - Programa Universidade para Todos, que prevê bolsas de estudos para alunos carentes, entre eles, especificamente negros, indígenas e deficientes físicos, conforme art. $7^{\circ}$, inciso II, da referida lei. Analisaremos o voto do Relator Ministro Carlos Ayres Britto, de 02 de abril de 2008, favorável às ações afirmativas, pois julgou constitucional a lei 11096/05.

Em relação à suposta violação do direito à igualdade, presente no caput do art. $5^{\circ}$, da Constituição, ele afirma que a única maneira de concretizar o valor constitucional da igualdade é através do decidido combate aos fatores reais de desigualdade presentes na sociedade.

31. Com efeito, é pelo combate eficaz às situações de desigualdade que se concretiza, em regra, o valor da igualdade (valor positivo,aqui, valor negativo ou desvalor, ali). Isto porque no ponto de partida das investigações metódicas sobre as coisas ditas humanas, ou seja, até onde chegam as lentes investigativas dos politicólogos, historiadores e sociólogos acerca das institucionalizadas relações do gênero humano, o que se comprova é um estilo de vida já identificado pela tarja das desigualdades (culturais, políticas econômicas e sociais). O desigual a servir como empírico portal da investigação científica e, daí, como desafio de sua eliminação pelas normas jurídicas ."157

Continuando seu raciocínio, discorre sobre desigualação legítima versus distinção ou discriminação ilegítimas.

36. Essa possibilidade de o Direito legislado usar a concessão de vantagens a alguém como uma técnica de compensação de anteriores e persistentes desvantagens factuais não é mesmo de se estranhar, porque o típico da lei é fazer distinções, diferenciações, desigualações. E fazer desigualações para contrabater renitentes desigualações. É como dizer: a lei existe para, diante dessa ou daquela desigualação que se revele densamente perturbadora da harmonia ou do equilíbrio social, impor uma outra desigualação compensatória . A lei como instrumento de reequilíbrio social. O que ela (a lei) não pode é incidir no "preconceito" ou fazer "discriminações", que nesse preciso sentido é que se deve interpretar o comando constitucional de que "Todos são iguais perante a lei , sem distinção de qualquer natureza". O vocábulo "distinção" a significar discriminação (que é proibida), e não enquanto simples diferenciação (que é inerente às determinações legais). ${ }^{158}$

${ }^{157}$ Voto do Ministro Carlos Britto, ADI 3330-1. Distrito Federal, STF, pg.30. Consulta na internet, endereço: www.sbdp.org.br/arquivos/material/284-Cotas___ADI_3330, acesso em 17-11-2008.

${ }^{158}$ Idem, pg. 33-34 


\section{Reiterando a necessidade da diferenciação, observados os elementos de "discrímen"}

legais ele diz:

37. (...)E como os fatores de desequilíbrio social têm nas mencionadas situações de desigualdade um tradicional componente, fica evidente que a fórmula pela qual a lei tem que operar é a diferenciação entre as partes.

38. É neste passo que se põe o delicado problema de saber que fatores de diferenciação compensatória a lei pode validamente erigir, tendo em vista que a nossa Constituição não os menciona. Não aponta os elementos de "discrímen" ou os dados de diferenciação de que a lei pode fazer uso. Apenas se refere àqueles de que o legislador não pode lançar mão. ${ }^{159}$

Em seguida ele cita critérios legais de diferenciação:

E o fato é que toda a axiologia constitucional é tutelar de segmentos sociais brasileiros historicamente desfavorecidos, culturalmente sacrificados e até perseguidos, como, verbi gratia, o segmento dos negros e dos índios. Não por coincidência os que mais se alocam nos patamares patrimonialmente inferiores da pirâmide social.

41. Nessa vertente de idéias, anoto que a desigualação em favor dos estudantes que cursaram o ensino médio em escolas públicas e os egressos de escolas privadas que hajam sido contemplados com bolsa integral não ofende a Constituição pátria, porquanto se trata de uma descrímen que acompanha a toada da compensação de uma anterior e factual inferioridade. Isso, lógico, debaixo do primacial juízo de que a desejada igualdade entre partes é quase sempre obtida pelo gerenciamento do entrechoque de desigualdades (uma factual e outra jurídica, esta última a contrabalançar o peso da primeira). ${ }^{160}$

$\mathrm{Na}$ petição inicial do processo, a Autora, representada por seus advogados, discorre sobre ações afirmativas, causando estranheza a declaração:

O único critério que o Estado está obrigado a observar, no tocante ao ensino superior, está previsto no art.208 , V, que reza: Art. 208. O dever do Estado com a educação será efetivado mediante a garantia de: V- acesso aos níveis mais elevados do ensino, da pesquisa e da criação artística , segundo a capacidade de cada um; razão pela qual as ações afirmativas nesse campo, deveriam levar o poder público a capacitar a todos para tal acesso, dando ensino básico de igual qualidade, outorgando bolsas de estudo aos de menor possibilidade econômica, e não pretender que, no ensino universitário, se outorguem privilégios a quem não esteja capacitado a acompanhá-lo, ainda que isso tenha derivado do fato de o Estado ter falhado em dar, no ensino básico e médio, a qualificação necessária. ${ }^{161}$ (grifo nosso)

Quem são os "privilegiados" que não estão capacitados a acompanhar o ensino universitário? Como pode saber a Autora da ação que esses "privilegiados” não estão

\footnotetext{
159 Ibdem, pg. 35

${ }^{160}$ Ibdem, pg. 36-37

${ }^{161}$ Petição Inicial do ADI 3330-1, DF, STF, pg. 24. , Consulta na Internet, endereço: www.stf.jus.br/portal/geral/verPdfPaginado.asp?id=181790\&tipo=TP8, acesso em 17-11-2008
} 
capacitados ou não são qualificados para cursar o nível superior?

Notamos, logo, no comentário da Autora, o perverso mecanismo do preconceito racial. A autora questiona a constitucionalidade do PROUNI, ferindo a imagem dos beneficiados, sugerindo que eles seriam menos capacitados ou menos qualificados a acompanhar o ensino superior. Citemos o comentário feito na decisão do Ministro Carlos Britto :

42. (...)Pressupor, como faz a Autora, que alunos de baixa renda selecionados conforme critérios sócio-econômicos e raciais têm, por isso, "menor qualificação" que os demais cidadãos brasileiros é que configura autêntica discriminação, em frontal ofensa ao art. $3^{\circ}$, incisos III e IV, e ao art. $5^{\circ}$ da Carta Constitucional. ${ }^{162}$ (grifo nosso)

Salientemos que o PROUNI é um programa de ações afirmativas que não fere o princípio da autonomia universitária (art. 207 ,CF), pois a adesão a este pelas Instituições de Ensino Superior Privadas é voluntária.

\subsection{Conteúdo jurídico do princípio da igualdade}

Cumpre argumentar quanto ao princípio da isonomia (igualdade de todos perante a lei) que a própria lei promove tratamentos desiguais, como é o caso da aposentadoria para homens e para mulheres: o tempo para as mulheres é de 30 anos de serviço, enquanto que para os homens o tempo é 35 anos. Mello recorda a máxima de Aristóteles conforme a qual a igualdade consiste em tratar igualmente os iguais e desigualmente os desiguais. No entanto, cabe a pergunta "Quem são os iguais e quem são os desiguais?(...) Em suma: qual o critério legitimamente manipulável - sem agravos à isonomia - que autoriza distinguir pessoas e situações em grupos apartados para fins de tratamentos jurídicos diversos?"163

Mello estabelece que:

\footnotetext{
${ }^{162}$ Voto do ministro Carlos Britto, ADI 3330-1 Distrito Federal, STF, pg.38-39. Consulta na internet, endereço: www.sbdp.org.br/arquivos/material/284-Cotas___ADI_3330, acesso em 17-11-2008.
}

${ }^{163}$ MELlO, Antônio Bandeira de. Conteúdo Jurídico do Princípio da Igualdade. São Paulo: Malheiros Editores, 2007, p.11. 
As discriminações são recebidas como compatíveis com a cláusula igualitária apenas e tão- somente quando existe um vínculo de correlação lógica entre a peculiaridade diferencial acolhida por residente no objeto, e a desigualdade de tratamento em função dela conferida, desde que tal correlação não seja incompatível com interesses prestigiados na Constituição. ${ }^{164}$

\begin{abstract}
Disso decorre que "fator algum pode ser escolhido aleatoriamente, isto é, sem pertinência lógica com a diferenciação procedida."165 Daí deve-se evitar discriminações injustificadas, e nas palavras de Pimenta Bueno:
\end{abstract}

A lei deve ser uma e a mesma para todos; qualquer especialidade ou prerrogativa que não for fundada só e unicamente em uma razão muito valiosa do bem público será uma injustiça e poderá ser uma tirania. ${ }^{166}$

Mello reconhece que as diferenciações que não podem ser feitas sem quebra da isonomia se dividem em três questões:

a) a primeira diz com o elemento tomado como fator de desigualação; b) a segunda reporta-se à correlação lógica abstrata existente entre o fator erigido em critério de discrímen e a disparidade estabelecida no tratamento jurídico diversificado; c) a terceira atina à consonância desta correlação lógica com os interesses absorvidos no sistema constitucional e destarte juridicizados. ${ }^{167}$

\title{
É o próprio Mello quem esclarece:
}

tem-se que investigar, de um lado, aquilo que é adotado como critério discriminatório; de outro lado, cumpre verificar se há justificativa racional, isto é, fundamento lógico, para, à vista do traço desigualador acolhido, atribuir o específico tratamento jurídico construído em função da desigualdade proclamada. Finalmente, impende analisar se a correlação ou o fundamento racional abstratamente existente é, in concreto, afinado com os valores prestigiados no sistema normativo constitucional. ${ }^{168}$

Podemos sintetizar da seguinte maneira. Para que sejam feitas discriminações frente ao princípio da isonomia, é necessário levar em conta: 1) o critério de discriminação; 2) a justificativa racional; 3) se há afinação com os preceitos constitucionais.

\footnotetext{
${ }^{164}$ Ibdem, p. 17

${ }^{165}$ Ibdem, p. 18

${ }^{166}$ PIMENTA BUENO. Apud op. cit. p.18

${ }^{167}$ MELLO, Antônio Bandeira de. Op. cit. p.21

${ }^{168}$ Ibdem, p. 21-22
} 
Analisemos a isonomia e o fator de discriminação. Este não pode particularizar determinado indivíduo, a não ser que ele seja um sujeito indeterminado e indeterminável no presente, como por exemplo, no preceito: "Será concedido o benefício tal ao primeiro que inventar um motor cujo combustível seja a água."169 Também, conforme Mello, é inadmissível, perante a isonomia, discriminar pessoas ou situações ou coisas mediante traço diferencial que não seja nelas mesmas residentes. Por exemplo, não pode ser deferido um tratamento a pessoas que habitem certo lugar, só por isso, mas poderá haver um tratamento diferenciado se naquele determinado lugar, há características próprias do lugar que justifiquem a diferenciação. ${ }^{170}$ Quanto ao tempo: “a lei não pode tomar tempo ou data como fator de discriminação entre pessoas a fim de lhes dar tratamentos díspares, sem com isto pelejar à arca partida com o princípio da igualdade. O que pode tomar como elemento discriminador é o fato, é o acontecimento, transcorrido em certo tempo por ele delimitado."171 Por exemplo, o tempo que transcorre para que um servidor público torne-se estável. O que conta não é o tempo em si, que é neutro, mas “o que ocorreu ao longo dele, uma certa sucessão, uma dada persistência continuada no exercício do cargo." $" 172$

Observemos agora a correlação lógica entre fator de discrímen e a desequiparação procedida, ou, em outras palavras, a justificação racional para a discriminação. Nas palavras de Mello:

tem-se que investigar, de um lado, aquilo que é erigido em critério discriminatório e, de outro lado, se há justificativa racional para, à vista do traço desigualador adotado, atribuir o específico tratamento jurídico construído em função da desigualdade afirmada ${ }^{173}$

Utilizemos o exemplo do próprio Mello. Suponhamos uma lei que permitisse aos funcionários gordos irem a um congresso religioso, recebendo remuneração, mas não permitisse aos magros. Neste exemplo não há nexo entre compleição física e facultar ir ou não a um congresso religioso. Por outro lado, a compleição física pode ser importante em funções que reclamem presença imponente. ${ }^{174}$

\footnotetext{
${ }^{169}$ Ibdem, p. 25

${ }^{170}$ Ibdem, p. 30-31

${ }^{171}$ Ibdem, p.33

172 Ibdem, p.31

${ }^{173}$ Ibdem, p.38

${ }^{174}$ Ibdem, p.38
} 
Examinemos por fim a consonância da discriminação com os interesses protegidos na Constituição. Conforme Mello, não basta estabelecer um nexo entre a diferença e um conseqüente tratamento diferenciado. É necessário que o vínculo demonstrável seja constitucionalmente pertinente. ${ }^{175}$ Mello cita como exemplo o caso de grandes grupos empresariais e empresas de porte médio, onde as primeiras seriam favorecidas fiscalmente sob o argumento de sua maior produtividade. Tal discriminação vai contra o art. 173, $\S 4^{\circ}$ da Constituição, segundo o qual "A lei reprimirá o abuso do poder econômico que vise à dominação dos mercados, à eliminação da concorrência e ao aumento arbitrário dos lucros", além de distanciar-se dos ditames da justiça social (art. 170, caput). ${ }^{176}$ Logo, o exemplo citado mostra-se inconstitucional.

\subsection{Limites para as ações afirmativas}

Podemos dizer que a ação afirmativa cumpre o papel de "tratar desigualmente os desiguais, na medida em que se desigualam”. Porém questões importantes surgem: Quem são os desiguais? Como deve ser esse tratamento desigual? Qual a medida? Essas questões devem ser bem respondidas, sob o risco de que a ação afirmativa descumpra aquilo a que se propõe, ou seja, propagar a igualdade e acabe gerando desigualdade, discriminação ou privilégios.

Segundo Celso Antônio Bandeira de Mello:

A Lei não deve ser fonte de privilégios ou perseguições, mas instrumento regulador da vida social que necessita tratar eqüitativamente todos os cidadãos. Este é o conteúdo político-ideológico absorvido pelo princípio da isonomia e juridicizado pelos textos constitucionais em geral, ou de todo modo assimilado ${ }^{177}$

Para Manoel Gonçalves Ferreira Filho, a fim de que a ação afirmativa não viole o princípio constitucional de igualdade:

\footnotetext{
${ }^{175}$ Ibdem, p.42

${ }^{176}$ Ibdem, p.43

${ }^{177}$ MELLO, Celso Antônio Bandeira de. O conteúdo jurídico do princípio da igualdade. São Paulo: Editora Revista dos Tribunais, 1978, p. 14
} 
- é preciso que sua estruturação normativa observe algumas condições.

Primeira, a identificação do grupo desfavorecido, e seu âmbito, deve ser objetivamente determinado. Regra de Objetividade. Não pode ser arbitrariamente definido, por exemplo, pela utilização de conceitos imprecisos, ou por meros critérios políticos (melhor se diria, políticoeleitorais). (...)

Segunda, a medida do avantajamento decorrente das regras deve ser ponderada em face da desigualdade a ser corrigida. Regra de Medida. Ou, como se costuma dizer, deve ser proporcional o avantajamento à desigualdade a reparar. Por isso, alguns a chamam de Regra de Proporcionalidade. (...)

Terceira condição. As normas de avantajamento devem ser adequadas à correção do desigualamento a corrigir. Regra de Adequação. Tal adequação se exprime na sua racionalidade. Por isso, é também uma Regra de Razoabilidade.

Quarta condição, a finalidade dessas normas deve ser a correção de desigualdades sociais. Regra da Finalidade. (...)

Quinta, enfim. As medidas, como aponta a Convenção Internacional sobre a Eliminação de todas as Formas de Discriminação Racial, devem ser temporárias. Regra da Temporariedade. ${ }^{178}$

Citemos um exemplo onde a ação afirmativa agiu ferindo o princípio de proporcionalidade. Trata-se de uma jurisprudência do Estado do Rio de Janeiro, na Oitava Câmara Cível, apelação cível $n^{\circ}$ 2005.001.23440, apelante Universidade do Estado do Rio de Janeiro - UERJ, apelado D. S. N., relatora des. Odete Knaack de Souza ${ }^{179}$.

A seguir o relatório do acórdão:

“Vistos, relatados e discutidos estes autos de apelação cível $n^{\circ} 2005.001 .23440$, em que é apelante UNIVERSIDADE ESTADUAL DO RIO DE JANEIRO - UERJ e apelado D. S. N., ACORDAM

Os desembargadores que compõem a OITAVA CAMMARA CÍVEL, em negar provimento ao recurso, nos termos do voto da Relatora. Unânime.

VOTO

${ }^{178}$ FERREIRA FILHO, Manoel Gonçalves. "Aspectos jurídicos das ações afirmativas.” Revista do Tribunal Superior do Trabalho, Brasília, ano 69, n. 2, p. 75-76, jul./dez.2003.

${ }^{179}$ SOUZA, Odete Knaack (relatora). Decisão proferida em apelação cível. Oitava Câmara Civil do Estado do Rio de Janeiro; Autos 2005.001.23440. 
A sentença deu adequada solução ao litígio e merece ser mantida, resistindo incólume às críticas formuladas.

Como informou a UERJ, o agravado prestou o vestibular UERJ/2003, tendo obtido ao final um total de 78,50 pontos, classificando-se em $12^{\circ}$ lugar, num total de 18 vagas, não logrando a obtenção de vaga, face ao atendimento da Lei 3.708/01.

Ao curso pretendido foram disponibilizadas 36 vagas totais.

O mandado de segurança foi impetrado na égide das Leis 3.524/00 e 3.078/01, hoje revogadas e substituídas pela Lei 4.151/03, que instituiu nova disciplina sobre o sistema de cotas para o ingresso nas universidades públicas estaduais.

Não obstante revogadas, a análise da questão permanece adstrita às referidas leis, pois o tempo rege o ato, sobre as quais se faz um breve histórico.

A partir da edição da Lei 3.524/00, a UERJ passou a realizar dois processos seletivos distintos, o primeiro para os alunos da rede pública, denominado SADE, tendo por base o desempenho escolar, e o segundo, destinado as demais concorrentes, com os requisitos tradicionais dos vestibulares.

A Lei 3.524/00 determinava que 50\% das vagas oferecidas para acesso a todos os cursos de graduação das universidades públicas estaduais deveriam ser preenchidas por alunos que tivessem cursado os ensinos fundamental e médio em instituições da rede pública municipal e/ou estadual.

Com a edição da Lei Estadual 3.708/01 estabeleceu-se a reserva de 40\% das vagas não destinadas ao SADE para candidatos auto-declarados negros ou pardos.

In casu, no curso para o qual se candidatou foram oferecidas 36 vagas totais, sendo 18 para o vestibular SADE e 18 para o vestibular tradicional, das quais, 14 vagas foram reservadas aos auto-declarados negros ou pardos, restando tão somente 4 vagas para os demais concorrentes. 
A UERJ faz longa explanação em defesa do beneficio social produzido através da implantação das chamadas ações afirmativas, o qual, diga-se, são muitos.

A ação afirmativa é um termo de amplo alcance que designa um conjunto de estratégias, iniciativas politicas que visam favorecer grupos ou segmentos sociais que se encontram em piores condições de competição em qualquer sociedade, na maioria das vezes, da prática de discriminações negativas, passadas ou presentes.

As ações afirmativas são medidas que buscam eliminar os desequilibrios existentes entre determinadas categorias sociais, o que se realiza por meio de providências efetivas em favor de categorias que se encontram em posições desvantajosas, não necessariamente as categorias minoritárias.

No Estado Constitucional, de democracia social, o princípio da igualdade jurídica não mais se limita a uma igualdade formal ou isonômica, como inicialmente concebido pelos revolucionários franceses, ganha traços acentuados de uma igualdade material, ou seja, deixa de ser apenas um dos pilares do Estado de Direito, para tornar-se um dos sustentáculos do Estado Social, sendo compreendido como instrumento hábil para implementar, no plano real, uma igualdade efetiva.

A busca por essa igualdade material corresponde a uma concentração de esforços para se estabelecer o nivelamento dos grupos sociais em seus diversos segmentos.

O sistema de cotas é, portanto, uma das modalidades existentes de ação afirmativa.

Contudo, vê-se dos autos que, no intuito de corrigir ou minorar distorções sociais, tais sistemas, da maneira como implantados, vieram a criar outras distorções, inaugurando nova espécie de desigualdade, agora voltada contra os concorrentes do grupo social que disputa o vestibular tradicional, ferindo o princípio da igualdade, em sua face material. 
O sistema de cotas instituídos por ambas as Leis Estaduais, em conjunto, vieram a beneficiar, duplamente, o mesmo grupo social. Através do sistema SADE, reservou-se o igresso aos alunos da rede pública, em sua maioria negros e pardos, vindo a Lei 3.708/01 a instituir nova reserva de vagas para negros e pardos, independentemente do sistema SADE.

Dados do último senso do IBGE revelam que a maioria da população é da raça branca. Sendo também a quantitativa maioria em idade escolar. O quantitativo da população de raça negra somada aos pardos é significativamente inferior ao da população de raça branca.

Portanto, não se pode conceber que num concurso destinado à uma sociedade com tais características, das 36 vagas ofertadas, somente 4 fossem destinadas ao vestibular normal, sem qualquer espécie das iniciativas politicas implantadas pelas referidas Leis Estaduais, ressalte-se, hoje revogadas.

O juízo a quo considerou que o sistema de cotas, tal como fora implementado, era iníquo e violava os princípios da isonomia e da proporcionalidade.

Com efeito, o sistema das Leis 3.524/00 e 3.078/01 revelou-se iníquo e desproporcional, tanto assim que a Lei 4.151/03 unificou os critérios e determinou a reserva de 45\% das vagas para estudantes carentes, distribuídos em três grupos, quais sejam, estudantes negros (20\%), estudantes da rede pública de ensino (20\%) e pessoas com deficiências e integrantes de minorias étnicas (5\%).

No caso dos autos, a questão demonstrou maior iniqüidade porque, aliada ̀̀ desproporção trazida pelo sistema legal, a UERJ ultrapassou o percentual destinado aos negros e pardos, reservando mais de 40\% das vagas ao sistema de cotas, no que feriu frontalmente o direito do impetrante.

Por tais motivos, voto no sentido de negar provimento ao recurso.

Rio de Janeiro, 24 de janeiro de 2006." 
Em trechos do relatório, os desembargadores mostraram simpatia pelas ações afirmativas. Porém, a avaliação do caso indica flagrante descumprimento da regra da proporcionalidade, como foi bem demonstrado pelo relatório. A UERJ soube identificar os sujeitos da ação afirmativa, e o que fazer para igualá-los, ou seja, o sistema de cotas. Mas errou quanto à regra da medida, exagerando no número de cotas para os sujeitos da ação afirmativa, privilegiando-os desproporcionalmente em relação ao grupo concorrente sob as regras tradicionais do vestibular.

Atualmente, as ações afirmativas da UERJ são mais equilibradas, e o público-alvo bemdefinido: $45 \%$ das vagas são destinadas a candidatos carentes (renda máxima individual R\$ $960,00)$. Dessas vagas, $20 \%$ para estudantes oriundos da rede pública de ensino, $20 \%$ para estudantes de cor de pele negra e 5\% para pessoas com deficiência, integrantes de minoria étnicas, filhos de policiais civis, militares, bombeiros militares e de inspetores de segurança e administração penitenciária, mortos em razão do serviço. 


\section{Propostas de implementação das políticas de ação afirmativa para a população negra no Brasil}

\subsection{Trezentos anos da morte de Zumbi de Palmares e a Marcha do Movimento Negro em Brasília em 1995}

Em 20 de novembro de 1995, ocorreu em Brasília a Marcha Zumbi dos Palmares pela Igualdade, a Cidadania e a Vida, reunindo cerca de 30 mil manifestantes. A data correspondeu aos 300 anos da morte de Zumbi, principal liderança do Quilombo dos Palmares, um território em Pernambuco que virou símbolo da resistência ao regime escravista e da consciência negra no país. $\mathrm{O}$ ato denunciou a ausência de políticas públicas para a população negra. Foi entregue uma carta ao Presidente da República, Fernando Henrique Cardoso, denunciando o racismo, defendendo a inclusão social dos negros na sociedade brasileira e apresentando propostas de políticas públicas. A carta trazia análises sobre a situação do negro nas áreas de saúde, educação, trabalho e violência. Entre as propostas de políticas públicas havia a de "Estabelecimento de incentivos fiscais às empresas que adotarem programas de promoção da igualdade racial" no item Mercado de Trabalho e "Desenvolvimento de ações afirmativas para o acesso dos negros aos cursos profissionalizantes, à universidade e às áreas de tecnologia de ponta" no ítem Educação. ${ }^{180}$.

A Marcha Zumbi dos Palmares também gerou como resposta do governo a criação do GTI, Grupo de Trabalho Interministerial para a Valorização da População Negra.

\subsection{Seminário Internacional "Multiculturalismo e Racismo: o papel da ação afirmativa nos estados democráticos contemporâneos"}

O Ministério da Justiça realizou em julho de 1996 o seminário "Multiculturalismo e Racismo: o papel da ação afirmativa nos estados democráticos contemporâneos", do qual

${ }^{180}$ Consulta na internet, endereço www.Irohin.org.br/ref/docs/doc03.doc, acesso em 05/12/2007. 
participaram pesquisadores brasileiros e americanos, bem como lideranças negras do país. Segundo Guimarães, "foi a primeira vez que um governo brasileiro admitiu discutir políticas públicas específicas voltadas para a ascensão dos negros no Brasil." 181

No discurso de abertura o presidente Fernando Henrique Cardoso admitiu haver discriminação e preconceito no país e pediu criatividade aos participantes na busca de soluções: "Devemos buscar soluções que não sejam pura e simplesmente a repetição, a cópia de soluções imaginadas para situações onde também há discriminação, onde também há preconceito, mas num contexto diferente do nosso. É melhor, portanto, buscarmos uma solução mais imaginativa." 182

\subsection{Conferência Mundial de Combate ao Racismo, Discriminação Racial, Xenofobia e Intolerância Correlata - Durban - 2001}

Para a participação brasileira na III Conferência Mundial de Combate ao Racismo, Discriminação Racial, Xenofobia e Intolerância Correlata ${ }^{183}$, realizada em Durban, África do Sul, no período de 31 de agosto a 07 de setembro de 2001, "o presidente da República estabeleceu um Comitê Nacional, composto paritariamente por representantes de órgãos do Governo e da sociedade civil organizada."184

A preparação para a Conferência de Durban envolveu a organização de Pré-Conferências Regionais, que desenvolveram várias temáticas, constituindo a base para a I Conferência Nacional contra o Racismo e a Intolerância que se realizou no Rio de Janeiro, na Universidade Estadual do Rio de Janeiro (UERJ), nos dias 6, 7 e 8 de julho, de 2001. Essa I Conferência

\footnotetext{
${ }^{181}$ GUIMARÃES, Antonio Sérgio Alfredo. Racismo e Anti-Racismo no Brasil. São Paulo: Ed. 34, 1999, p. 165.

${ }^{182}$ Consulta na internet, endereço www.planalto.gov.br/publi_04/colecao/racial1B.htm, acesso em 05/12/2007

${ }^{183}$ Passaremos a designar a III Conferência Mundial de Combate ao Racismo, Discriminação Racial, Xenofobia e Intolerância Correlata como Conferência de Durban.

${ }^{184}$ Relatório do Comitê Nacional para a Preparação da Participação Brasileira na III Conferência Mundial das Nações Unidas contra o Racismo, Discriminação Racial, Xenofobia e Intolerância Correlata (Durban, 31 de agosto a 07 de setembro de 2001). Brasília: Ministério da Justiça, Secretaria de Estado dos Direitos Humanos, 2001, p. 9.
} 
Nacional gerou um documento denominado "Plano Nacional de Combate ao Racismo e à Intolerância - CARTA DO RIO”. ${ }^{185}$

Para se chegar a esse documento, muito esforço do movimento negro foi despendido, com destaque para os movimentos das mulheres negras.

a III Conferência Mundial contra o Racismo, Discriminação Racial, Xenofobia e Intolerâncias Correlatas foi motivo de grandes expectativas e esperanças para o Movimento Negro do Brasil e para o conjunto da população negra. Tais expectativas refletiram-se no intenso engajamento das organizações negras brasileiras na construção e realização da Conferência Mundial contra o Racismo. ${ }^{186}$

Para tanto, foi constituído em abril de 2000, um Comitê Impulsor Pró-Conferência, formado por lideranças de organizações negras e sindicais.

O comitê foi responsável pela constituição do Fórum Nacional das Entidades Negras para a III Conferência contra o Racismo, a partir do qual foi elaborado um documento das entidades negras sobre os efeitos do racismo no Brasil e formadas delegações para a participação no processo da Conferência. ${ }^{187}$

Em relação à organização feminina,

destaca-se a Articulação de Organizações de Mulheres Negras Brasileiras Pró-Durban, composta por mais de uma dezena de organizações de mulheres negras do país e coordenada pelo Criola, organização de mulheres negras do Rio de Janeiro, pelo Geledés/Instituto da Mulher Negra, de São Paulo e pelo Maria Mulher, do Rio Grande do Sul. ${ }^{188}$

Foi editado o Jornal da Rede, dedicado à III Conferência, em março de 2001, com objetivo de divulgar estudos sobre raça/etnia e saúde. Também foi feito o documento da Articulação de Mulheres Brasileiras (AMB) - Mulheres Negras: um retrato da discriminação racial no Brasil, destinado a mais uma contribuição à Conferência de Durban. ${ }^{189}$

${ }^{185}$ PLANO NACIONAL DE COMBATE AO RACISMO E À INTOLERÂNCIA - CARTA DO RIO. Rio de Janeiro, 08 de julho de 2001. Consulta na internet, endereço www.mj.gov.br/sedh/rndh/carta\%20do\%20Rio.pdf. Acesso em 02-09-2008.

${ }^{186}$ CARNEIRO, Sueli. A batalha de Durban. Rev. Estud. Fem., Florianópolis, v. 10, n.1, 2002, p.2. Consulta na internet em www.scielo.br/scielo.php?script=sci_arttext\&pid=S0104-026X2002000100014\&Ing=em\&nrm=isso $>$ Acesso em 04-08-2008.

187 ibdem, p. 2

${ }^{188}$ ibdem, p. 3

${ }^{189}$ ibdem, p.4-5 
Além de ativistas do Movimento Negro e de organizações não-governamentais, participaram da I Conferência Nacional contra o Racismo e a Intolerância sacerdotes religiosos afro-brasileiros, especialistas acadêmicos, profissionais liberais, diplomatas, parlamentares, gestores de políticas públicas e representantes de sindicatos.

Os trabalhos dessa Conferência Nacional se desenvolveram em torno de 13 grupos temáticos, onde cada um produziu um conjunto de proposições, com intuito de fornecer subsídios para o relatório brasileiro à Conferência de Durban.

As temáticas foram as seguintes:

$\begin{array}{ll}1- & \text { Raça e etnia } \\ 2- & \text { Cultura e Comunicação } \\ 3- & \text { Religião } \\ 4- & \text { Orientação Sexual } \\ 5- & \text { Educação, Saúde e Trabalho } \\ 6- & \text { Acesso à Justiça e Defesa dos Direitos Humanos } \\ 7- & \text { Questão Indígena } \\ 8- & \text { Necessidades Especiais } \\ 9- & \text { Gênero } \\ 10- & \text { Remanescentes de Quilombos } \\ 11- & \text { Xenofobia } \\ 12- & \text { Migrações Internas } \\ 13- & \text { Juventude }\end{array}$

Verifiquemos a seguir, dentro de alguns grupos temáticos, reivindicações referentes às ações afirmativas. Há recorrência de algumas delas, o que mostra a importância das mesmas.

\section{Raça e etnia}

Propostas: "que sejam implementadas políticas de ação afirmativa na área da educação como instrumento fundamental de promoção da igualdade; que sejam estabelecidas cotas para 
população negra nas universidades; (...) que sejam implantados no currículo escolar da rede pública municipal e particular, assim como nas universidades estaduais e nacionais, a história da África e as verdadeiras contribuições do povo afro-descendente na construção da formação política, religiosa e social do Brasil; (...) que sejam criadas cotas para afro-descendentes nos cargos comissionados no $1^{\circ}, 2^{\circ}, 3^{\circ}$ escalões do serviço público nos diversos níveis de governo, especialmente do Executivo Federal; (...) que os contratos públicos com agências de publicidade, propaganda e mídia em geral, contenham cláusula específica referente à participação de negros e negras e à não-discriminação de gênero e raça, com representação estereotipada." 190

\section{Cultura e Comunicação}

Propostas: "que os programas de incentivo à cultura determinem ações afirmativas de inclusão de negros e minorias nas produções contempladas com seu apoio; que sejam criados Fundos (Estadual, Municipal e Federal) para financiar o desenvolvimento e implantação de estruturas de mídia e TV para a população negra; (...) que sejam estabelecidas cotas para a produção negra no orçamento proveniente da lei de incentivo à cultura; (...) que sejam instituídas cotas de participação de ator/artistas negros em todos os níveis; (...) manter a obrigatoriedade da presença de negros na publicidade oficial federal, estimulando a extensão desta obrigatoriedade aos estados e municípios, de modo que reflita a sua participação no conjunto da população do País.",191

\section{Educação, Saúde e Trabalho}

Propostas: "colocar em prática programas de saúde específicos para doenças que afetam a população negra de modo forte - hipertensão arterial, anemia falciforme, diabetes II, entre outras; (...) estabelecimento de cotas para negros nas Universidades; linhas de crédito para pequenos empreendedores negros e empresários negros; implementação de um programa nacional de ação afirmativa para empreendedores afro-brasileiros nas compras

\footnotetext{
${ }^{190}$ PLANO NACIONAL DE COMBATE AO RACISMO E À INTOLERÂNCIA - CARTA DO RIO. Rio de Janeiro, 08 de julho de 2001. Consulta na internet, endereço www.mj.gov.br/sedh/rndh/carta\%20do\%20Rio.pdf. Acesso em 02-09-2008, p. 7-8.

${ }^{191}$ ibdem, p.10-11
} 
governamentais; estabelecimento de cotas para negros nos concursos públicos tal como existem para deficientes físicos." 192

\section{Acesso à Justiça e Defesa dos Direitos Humanos}

Propostas: "implementação de Ações Afirmativas em todas as esferas de poder dos estados, municípios e nação; (...) criar cotas nos partidos para garantir a eleição de negros." 193

\section{Gênero}

Propostas: inclusão de cláusula de promoção da igualdade de gênero e raça da mão de obra contratada pelas empresas que celebram contratos com os governos (federal, estadual e municipal), como fator de classificação em concorrências públicas; (...) projetos de apoio financeiro a empreendedoras negras; (...) contratos públicos celebrados pelo governo, com agências de publicidade, propaganda e mídia em geral, que deverão conter cláusula específica referente a participação de negros e negras e a não discriminação de gênero e raça; (...) o Estado Brasileiro deve assegurar a participação eqüitativa dos afrodescendentes em todos os meios de comunicação (visual e de rádio difusão) e entretenimento."194

\section{Juventude}

Propostas: "políticas de ações afirmativas, inclusive para a inserção de jovens negros (as) nas universidades; inserção, no ensino básico e superior, de história da África, de línguas africanas na grade curricular atrelada à formação docente na área; bem como a história da África como disciplina obrigatória do vestibular das universidades públicas."

As propostas transcritas acima são de grande importância ao avaliarmos as ocorrências subseqüentes à Conferência de Durban. Destaca-se a incidência de reivindicação de cotas para negros nas universidades, cotas para negros na mídia, e a inserção na grade curricular do ensino de História da África.

\footnotetext{
192 ibdem, p. 21

193 ibdem, p. 24-25

${ }^{194}$ ibdem, p.33-34,36

195 ibdem, p. 47
} 
Esse processo preparatório contribuiu para a formulação do "Relatório do Comitê Nacional para a preparação da participação brasileira na III Conferência Mundial das Nações Unidas Contra o Racismo, Discriminação Racial, Xenofobia e Intolerância Correlata", o qual propôs uma agenda para servir como intervenção do Brasil na Conferência de Durban. Quanto à comunidade negra, o Relatório do Comitê Nacional afirma:

Com efeito, o racismo e as práticas discriminatórias disseminadas no cotidiano brasileiro não representam simplesmente uma herança do passado. O racismo vem sendo recriado e realimentado ao longo de toda nossa história. ${ }^{196}$

E entre as várias propostas para a comunidade negra estão:

\begin{abstract}
. Regulamentação urgente do artigo 68 do Ato das Disposições Constitucionais Transitórias da Constituição Federal, que dispõe sobre o direito dos remanescentes das comunidades dos quilombos ao reconhecimento da propriedade definitivas de suas terras;

(...)

. adoção de cotas ou outras medidas afirmativas que promovam o acesso de negros às universidades públicas. ${ }^{197}$
\end{abstract}

Notamos nesses documentos, a clara intenção de aplicação de ações afirmativas para a população negra.

O Brasil teve boa participação na Conferência de Durban, atuando como mediador entre os países da África e os países europeus, naquilo que se denominou "temas do passado". Esses temas tiveram grande repercussão, com alguns países africanos reivindicando reparações pela escravidão, o que gerou muita polêmica. Outro tema polêmico foi a questão palestina, com os países árabes acusando Israel de praticar um novo "apartheid' com o povo palestino. EUA e Israel retiraram-se da Conferência por discordar dessa posição.

Como exemplos de alguns dos resultados da conferência, a escravidão e o tráfico de seres humanos foram considerados crimes contra a humanidade, mas sem as reparações pretendidas. Conforme texto da Declaração de Durban, no título "Questões Gerais":

\footnotetext{
${ }^{196}$ Relatório do Comitê Nacional para a Preparação da Participação Brasileira na III Conferência Mundial das Nações Unidas contra o Racismo, Discriminação Racial, Xenofobia e Intolerância Correlata (Durban, 31 de agosto a 07 de setembro de 2001). Brasília: Ministério da Justiça, Secretaria de Estado dos Direitos Humanos, 2001, p. 25.

${ }^{197}$ Ibdem, p. 29-30.
} 
13. Reconhecemos que a escravidão e o tráfico escravo, incluindo o tráfico de escravos transatlântico, foram tragédias terríveis na história da humanidade, (...) ainda reconhecemos que a escravidão e o tráfico escravo são crimes contra a humanidade e assim devem sempre ser considerados, especialmente o tráfico de escravos transatlântico, estando entre as maiores manifestações e fontes de racismo, discriminação racial, xenofobia e intolerância correlata; e que os Africanos e afrodescendentes, Asiáticos e povos de origem asiática, bem como os povos indígenas foram e continuam a ser vítimas destes atos e de suas conseqüências. ${ }^{198}$

Também foram pedidas ações afirmativas para as comunidades de origem africana. Na parte referente ao "Programa de ação" quanto aos africanos e afrodescendentes, a Conferência de Durban:

5. Solicita que os Estados, apoiados pela cooperação internacional, considerem positivamente a concentração de investimentos nos serviços de saúde, educação, saúde pública, energia elétrica, água potável e controle ambiental, bem como outras iniciativas de ações afirmativas ou de ações positivas, principalmente nas comunidades de origem africana. ${ }^{199}$

Outro ponto importante foi o reconhecimento de que as injustiças históricas têm contribuído para o subdesenvolvimento em diversas partes do mundo, e apela para a solidariedade como solução:

Estas injustiças históricas têm inegavelmente contribuído para a pobreza, subdesenvolvimento, marginalização, exclusão social, disparidades econômicas, instabilidade e insegurança que afetam muitas pessoas em diferentes partes do mundo, em especial, nos países em desenvolvimento. A conferência reconhece a necessidade de se desenvolverem programas para o desenvolvimento social e econômico destas sociedades e da Diáspora dentro, de uma estrutura de uma nova parceria baseada no espírito de solidariedade e respeito mútuo $(. . .)^{200}$

Vale ressaltar ainda que a Conferência de Durban exorta os Estados a cumprirem os planos de ação que declararam na Conferência. A Conferência:

167- Exorta os Estados a aplicarem diligentemente todos os compromissos assumidos por eles nas declarações e planos de ação das conferências regionais nas quais participaram, e a formularem políticas e planos de ação nacionais no combate ao racismo, discriminação racial, xenofobia e intolerância correlata, de acordo como os objetivos formalmente estabelecidos em tais declarações e planos, e segundo o previsto por outros instrumentos e decisões pertinentes; e, ainda, solicita que, nos casos em que tais políticas e planos de ação nacionais no combate ao racismo, discriminação

198 III CONFERÊNCIA MUNDIAL DE COMBATE AO RACISMO, DISCRIMINAÇÃO RACIAL, XENOFOBIA E INTOLERÂNCIA CORRELATA. Declaração de Durban e Plano de Ação. Ministério da Cultura - Fundação Cultural Palmares, p.18.

${ }^{199}$ idem, p. $42-43$

200 ibdem, p. 84, parágrafo 158, Programa de Ação. 
racial, xenofobia e intolerância correlata já existam, os Estados incorporem os compromissos resultantes de suas conferências regionais. ${ }^{201}$

\section{Repercussões da Conferência de Durban no Brasil}

No Brasil, após a Conferência de Durban, os debates sobre as ações afirmativas em favor dos negros se intensificaram, alcançando-se resultados. Diversas universidades passaram a adotar ações afirmativas para negros, indígenas, deficientes físicos e alunos egressos da escola pública. Nesse ano de 2001, o então governador do Rio de Janeiro, Anthony Garotinho sancionou uma lei oriunda da Assembléia Legislativa instituindo uma cota de 40\% para "negros e pardos" nas universidades públicas do Estado, mais 50\% para alunos oriundos das escolas públicas (essas cotas produziram demandas judiciais por ferirem o princípio da proporcionalidade e foram revistas). Em 2002 a UNEB (Universidade do Estado da Bahia), também instituiu cotas, seguida em 2003 pela UnB (Universidade de Brasília), pela UEMS (Universidade do Estado do Mato Grosso do Sul) e pela Fundação Joaquim Nabuco, de Recife. Outras mais foram estabelecendo cotas nos seus sistemas de ingresso.

Quanto a cotas no serviço público, a Prefeitura Municipal de Porto Alegre promulgou a Lei $\mathrm{N}^{\mathrm{o}} 494$, de 10 de setembro de $2003^{202}$, dispondo $12 \%$ das vagas dos concursos públicos do município de Porto Alegre para a população negra. A Câmara Municipal de Vitória promulgou em 24-11-2004 a Lei $\mathrm{N}^{\mathrm{o}} 6.225^{203}$, que reserva 30\% das vagas oferecidas em concursos públicos do município de Vitória para a população negra. A lei foi regulamentada em 16-032007, pelo decreto $\mathrm{N}^{\mathrm{o}} 13.249$.

Em 9 de janeiro de 2003 foi aprovada a lei 10.639/2003, alterando a Lei no 9.394/1996, a qual estabelece as diretrizes e bases da educação nacional. A lei 10.639/2003 obriga o ensino de História da África na grade curricular das escolas. Segundo essa lei:

\footnotetext{
${ }^{201}$ Ibdem, p. 88-89, parágrafo 167, Programa de Ação.

${ }^{202}$ Consulta na internet, endereço www.cmarapoa.rs.gov.br/biblioteca/integrais/LC_494.htm, acesso em 13-122008.

${ }^{203}$ Consulta na internet, endereço http//sistemas.vitoria.es.gov.br/webleis/Leis/D13249.pdf, acesso em 13-122008.
} 
"Art. 26-A. Nos estabelecimentos de ensino fundamental e médio, oficiais e particulares, torna-se obrigatório o ensino sobre História e Cultura Afro-Brasileira.

$\S 1^{\circ}$ O conteúdo programático a que se refere o caput deste artigo incluirá o estudo da História da África e dos Africanos, a luta dos negros no Brasil, a cultura negra brasileira e o negro na formação da sociedade nacional, resgatando a contribuição do povo negro nas áreas social, econômica e política pertinentes à História do Brasil.

$\$ 2^{\circ}$ Os conteúdos referentes à História e Cultura Afro-Brasileira serão ministrados no âmbito de todo currículo escolar, em especial nas áreas de Educação Artística e de Literatura e História Brasileiras."

Quanto aos remanescentes das comunidades dos quilombos, em 20 de novembro de 2003 foi publicado o decreto $\mathrm{n}^{\mathrm{o}} 4.887$, com o objetivo de regulamentar o procedimento para identificação, reconhecimento, delimitação, demarcação e titulação das terras ocupadas por remanescentes das comunidades dos quilombos de que trata o art. 68 do Ato das Disposições Constitucionais transitórias:

"Art.68. Aos remanescentes das comunidades dos quilombos que estejam ocupando suas terras é reconhecida a propriedade definitiva, devendo o Estado emitir-lhes os títulos respectivos."

O critério de identificação dos remanescentes das comunidades dos quilombos é a autodefinição da própria comunidade. Conforme decreto n ${ }^{\circ}$ 4887/2003:

"Art. $2^{\circ}$. Consideram-se remanescentes das comunidades dos quilombos, para fins deste Decreto, os grupos étnico-raciais, segundo critérios de auto-atribuição, com trajetória histórica própria, dotados de relações territoriais especificas, com presunção de ancestralidade negra relacionada com a resistência à opressão histórica sofrida.

$\$ 1^{\circ}$ Para os fins desse Decreto, a caracterização dos remanescentes das comunidades dos quilombos será atestada mediante autodefinição da própria comunidade." 
Atualmente há 3.524 comunidades remanescentes de quilombos no Brasil, dessas, 1.248 comunidades estão certificadas pela Fundação Palmares ${ }^{204}$. A certificação ocorre quando a comunidade se identifica como quilombola. O INCRA (Instituto Nacional de Colonização e Reforma Agrária) é o órgão responsável pelos processos administrativos necessários para a titulação das áreas quilombolas:

Já foram publicados 75 Relatórios Técnicos de Identificação e Delimitação (RTDI), o que significa a identificação de 582.440 hectares, em benefício de 9.873 famílias. O resultado é que comunidades de 97 áreas já possuem o título da terra, coletivo, indivisível e inegociável, expedido pelo INCRA ou por órgãos estaduais de terra conveniados. ${ }^{205}$

${ }^{204}$ Consulta na internet, endereço www.palmares.gov.br, acesso em 21/11/2008.

${ }^{205}$ Consulta na internet, endereço www.incra.gov.br, acesso em 21/11/2008 


\subsection{Quem são os negros?}

Quando se trata de discriminação, os negros são facilmente reconhecidos pelos seus traços fenotípicos (preconceito de marca). Quando se trata de beneficiar a população negra, inicia-se uma polêmica quanto à definição de quem é negro. Uma das argumentações diz que raças não existem, logo, não devemos fazer classificações raciais.

Por exemplo, criticando a portaria $\mathrm{n}^{\mathrm{o}} 156$ do Ministério da Educação (emitida em 20/10/2004), a qual solicitava que os alunos das escolas prestassem uma informação autodeclaratória sobre sua raça/cor, Goldenzon fala:

Quase não pude acreditar no que lia. O formulário, além de minha identificação e da minha filha, perguntava, em forma de múltipla escolha, qual a cor/raça dela - amarela, branca, indígena, parda ou preta, além de uma última opção: 'Opto por não declarar neste momento tal informação'. $O$ MEC estava pedindo para uma menina de sete anos 'autodeclarar' sua cor/raça!

Minha filha é branca, aliás, muito branca, já que todos os meus avós eram judeus poloneses. Entretanto, essa não é sua raça, apenas o tom de sua pele. Ela pertence à raça humana, como todos os seus colegas de turma (de vários tons de pele).

$\mathrm{Na}$ turma de minha filha existem algumas crianças negras. Elas estudam e brincam juntas, recebem as mesmas aulas, vestem uniforme igual e pagam a mesma mensalidade. Até hoje elas provavelmente se achavam iguais, crianças. Agora minha filha e seus coleguinhas saberão que não são mais apenas crianças, são crianças brancas, pardas, pretas ou amarelas (acho que não há índios nesse colégio $)^{206}$

Outros argumentos baseiam-se no mito da democracia racial. Um argumento contra a classificação racial é que aglutinar pretos e pardos na categoria de negros, desconsidera a gama de matizes de cor existente no Brasil graças à mestiçagem, negando, dessa forma, a identidade brasileira, que é a de um povo mestiço. Segundo Kamel:

Para mim, para o senso comum, para as pessoas que andam pelas ruas, negro era sinônimo de preto. Nos primeiros artigos, eu me debatia contra uma leitura equivocada das estatísticas oficiais acreditando nisso. Certo dia, caiu a ficha: para as estatísticas, negros eram todos aqueles que não eram brancos. Cafuzo, mulato, mameluco, caboclo, escurinho, moreno, marrom-bombom? Nada disso, agora ou eram brancos ou eram negros. De repente, nós que éramos orgulhosos da nossa

${ }^{206}$ GOLDENZON, Sidney. Eles deveriam pedir desculpas, de joelhos. In: FRY, Peter, MAGGIE, Ivone, MAIO, Marcos Chor, MONTEIRO, Simone e SANTOS, Ricardo Ventura (org.). Divisões Perigosas. Rio de Janeiro: Civilização Brasileira, 2007, p.151-152. 
miscigenação, do nosso gradiente tão variado de cores, fomos reduzidos a uma nação de brancos e negros. Pior: uma nação de brancos e negros onde os brancos oprimem os negros. Outro susto: aquele país não era o meu. ${ }^{207}$

\section{Criticando o ex-presidente Fernando Henrique Cardoso, Kamel responsabiliza-o pela} mudança de modelo de nação - uma nação tolerante e miscigenada para uma nação bicolor:

Não importa que pessoalmente ele rejeitasse, e ainda rejeite, as cotas - a adoção delas só se tornou possível porque, no governo, ele agiu de forma decisiva para que o ideal de nação miscigenada e tolerante fosse substituído pela nação bicolor em que brancos oprimem negros. ${ }^{208}$

Além de desconsiderar os mestiços, a classificação racial poderia criar problemas raciais para a nação, em vez de solucioná-los. Magnoli critica a fabricação de um país de brancos e negros, sem meio-tons, o que para ele, oficializaria o racismo:

Raças humanas são invenções culturais do poder político. O Império fabricou os 'pardos'. O Estado entrega-se agora à fabricação de um país de 'brancos' e 'negros', isento de meios-tons. Invertem-se os sinais de valor, à custa da atualização, legitimização e oficialização do artigo de fé do racismo, que é a classificação racial dos cidadãos. ${ }^{209}$

Fry também vê problemas na divisão da sociedade em "duas raças", a de "brancos" e "negros", pois além de consistir num "genocídio" dos "pardos", “caboclos", “morenos”, etc., poderia criar o que se pretende ver destruído [a raça]:

Se passar essa lei [projeto de lei 73/1999], os cidadãos serão divididos em duas 'raças' com direitos distintos de acordo com a sua pertença a uma ou a outra dessas duas categorias. A política de cotas raciais, como vem sendo denominada, institui, portanto, uma sociedade dividida entre 'brancos' e 'negros'. Em outros lugares do mundo esse tipo de engenharia social trouxe mais dor do que alívio para os problemas que visava solucionar.

(...)

O que está em jogo são dois projetos de combate ao racismo: um pela via do fortalecimento das identidades 'raciais' e, em última análise, do 'genocídio' dos 'pardos', 'caboclos', 'morenos' etc.; outro pela via do anti-racismo, que procura concentrar esforços na diminuição das diferenças de classe e em uma luta contínua contra as representações negativas atribuídas às pessoas mais escuras. (...)

\footnotetext{
${ }^{207}$ KAMEL, Ali. Não somos racistas: uma reação aos que querem nos transformar numa nação bicolor. Rio de Janeiro: Nova Fronteira, 2006, p. 18.

${ }^{208}$ Idem, p. 39.

${ }^{209}$ MAGNOLI, Demétrio. Pardos. In: FRY, Peter, MAGGIE, Ivone, MAIO, Marcos Chor, MONTEIRO, Simone e SANTOS, Ricardo Ventura (org.). Divisões Perigosas. Rio de Janeiro: Civilização Brasileira, 2007, p.120.
} 
Enfim, argumentamos que não se pode acabar com o racismo com uma política que entroniza a 'raça'. Quando o Estado legisla sobre esta matéria, ele funda a 'raça', cria justamente aquilo que quer ver destruído. ${ }^{210}$

Ainda sob parâmetros do mito da democracia racial, sendo o Brasil uma nação miscigenada, a argumentação seguinte é uma pergunta: como classificar esses mestiços? Segundo Zarur:

(...) com exceção das pessoas de pele muito escura, ninguém sabe, com certeza, o que é um 'negro' no Brasil. E para complicar, há ainda a chamada 'raça social', pois o jogador Ronaldo se considera 'branco', como os demais mestiços ricos se percebem. ${ }^{211}$

Kamel também identifica o problema de definir os mestiços e diz que não devemos fazer classificações, mas falar apenas em "brasileiros":

O problema é definir o que é pardo. Para mim é constrangedor ter de discutir nesses termos, eu que não tenho a cor de ninguém como critério de nada. (...) O pardo é um branco meio negro ou um negro meio branco? Chamar um pardo de afro-descendente é mais do que inapropriado, é errado.

Tenho uma amiga cujo pai é negro assim como todos os ascendentes dele. A mãe é italiana, assim como todos os ascendentes dela. Como chamá-la apenas de afro-descendente? Por que lógica? Se alguma lógica existe, o correto seria chamá-la de ítalo-afro-descendente ou afro-ítalo-descendente, como preferirem. E como todos os pardos são, na origem, fruto do casamento entre brancos (europeus) e negros (africanos), os pardos deveriam ser genericamente chamados de euro-afrodescendentes. Teriam, ainda assim, direito a cotas ou a outras políticas de preferência racial ou o prefixo 'euro' os condena irremediavelmente? Falando assim, tão cruamente, pretendo deixar claro como todas essas definições são em si racistas. Porque não devemos falar em negros, pardos ou brancos, mas apenas em brasileiros. ${ }^{212}$

Os argumentos que vimos criticam as classificações raciais. Porém, se vamos admitir classificações raciais, como fazê-las? O sistema utilizado prioritariamente no Brasil é o da autodeclaração, ou seja, é o próprio indivíduo quem declara a qual raça pertence. Mas concorrer no sistema de cotas consiste num benefício social, assim, há o temor de que indivíduos sem o perfil para as cotas fraudem o sistema. A opção seria a verificação dos candidatos por uma comissão examinadora, que decidiria se o candidato corresponde ao perfil para as cotas. Esse tipo de opção recebeu severas críticas, tanto dos que são contra as cotas para negros como dos que são a favor.

\footnotetext{
${ }^{210}$ FRY, Peter; MAGGIE, Yvonne. Política social de alto risco. Idem, p.280-281.

${ }^{211}$ ZARUR, George. Aprendizes de feiticeiros. Ibdem, p.130-131.

${ }^{212}$ KAMEL, Ali. Não somos racistas: uma reação aos que querem nos transformar numa nação bicolor. Rio de Janeiro: Nova Fronteira, 2006, p. 51.
} 
A UnB (Universidade de Brasília), no seu vestibular em 2004 instituiu cotas para negros. No ato de inscrição, os candidatos às cotas foram fotografados e uma comissão decidiu pela homologação ou não da inscrição baseando-se em características fenotípicas da raça negra. A comissão foi composta por seis pessoas: "uma estudante, um sociólogo, e um antropólogo da UnB, além de três representantes de entidades sociais ligadas ao movimento negro" ${ }^{\text {"213 }}$. Os candidatos rejeitados podiam entrar com recurso, e então ocorria a segunda etapa da avaliação, com apresentação de documentação e entrevista. Para essa segunda etapa foi feita uma segunda comissão formada "por professores da UnB e membros de ONGs"214.

Maio \& Santos fizeram um artigo criticando o sistema. Citam exemplos que sugerem ser o sistema de fotografias constrangedor para os candidatos ${ }^{215}$. Quanto à formação de uma comissão examinadora, dizem que não é possível estabelecer as pessoas certas para avaliar quem são os indivíduos com as características fenotípicas passíveis de sofrer discriminação:

(...) conforme indicou Dione Moura ${ }^{216}$, o objetivo da comissão seria o de 'olhar com os mesmos olhos da sociedade para beneficiar quem realmente deve participar do sistema [de cotas $]^{217}$.

$\mathrm{Na}$ lógica adotada pelos responsáveis pelo vestibular da UnB, um desafio que se impôs foi o de criar mecanismos que mimetizassem o que poderíamos chamar, a partir da metáfora sugerida por Moura, 'os olhos e filtros cognitivos' da sociedade. A difícil tarefa, diga-se de antemão de operacionalização impossível, seria de se chegar a uma 'comissão' imbuída desses 'olhos e filtros'. Nela estariam encapsulados os sentidos de uma coletividade ampla. Seriam as sensibilidades de um cidadão abstrato, mas representativo da sociedade nacional, que no seu dia-a-dia das interações sociais se defronta com outros que pode vir a discriminar com base em um dado conjunto de atributos raciais. ${ }^{218}$

Essa impossibilidade se deve "à elevada dose de contexto situacional e de ambigüidade que, como amplamente conhecido, marcam as percepções sobre raça no Brasil” ${ }^{219}$. Ou seja, definir a raça de um indivíduo depende do contexto em que se dão as interações entre os sujeitos e da subjetividade do avaliador.

\footnotetext{
${ }^{213}$ MEIRA, L. apud MAIO, Marcos Chor; SANTOS, Ricardo Ventura. "Política de cotas raciais, os 'olhos da sociedade' e os usos da antropologia: o caso do vestibular da Universidade de Brasília (UnB)" Horizontes Antropológicos, Porto Alegre, n.23, p. 191, jan/jun. 2005, p. 194.

${ }^{214}$ MAIO, Marcos Chor; SANTOS, Ricardo Ventura. Op. cit. p.194.

${ }^{215}$ MAIO, Marcos Chor; SANTOS, Ricardo Ventura. Op. cit. p.192.

${ }^{216}$ Dione Moura foi a "relatora da Comissão de Implantação do Plano de Metas de Integração Social, Étnica e Racial da UnB" idem, p. 193.

${ }^{217}$ AFONSO, I. apud MAIO, Marcos Chor; SANTOS, Ricardo Ventura. Op. cit. p.196.

${ }^{218}$ MAIO, Marcos Chor; SANTOS, Ricardo Ventura. Op. cit. p.196.

${ }^{219}$ MAIO, Marcos Chor; SANTOS, Ricardo Ventura. Op. cit. p.196.
} 
Outra preocupação de Maio \& Santos é a utilização de um antropólogo na comissão examinadora:

Dado o status de perito, a percepção do antropólogo quanto à identidade do sujeito da pesquisa passa a assumir 'ares de verdade'.20

A presença de um antropólogo seria a tentativa de alcançar cientificidade no processo de avaliação da comissão examinadora:

A dimensão de cientificidade incluía a presença de 'especialista em raça', no caso representado pelo

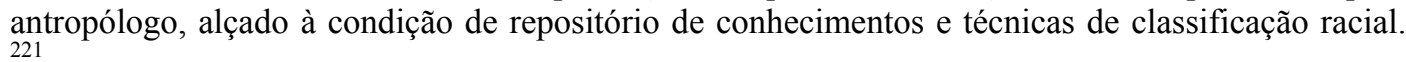

No entanto, o procedimento de verificação de fotografias assemelha-se a "práticas pretéritas e cientificamente superadas" ${ }^{\text {222 }}$, Maio \& Santos concluem:

Cabe lembrar que a ampla maioria das instituições que adotaram as cotas no país tem preferido depender unicamente da autodeclaração. Possivelmente avaliam que os custos sociais e históricos de implantar um 'tribunal racial' como foi rotulado o sistema da UnB, podem ser por demais elevados a médio e a longo prazo.

(...)

Argumentamos que, por várias razões, a 'antropologia das raças' peça de engenharia tecnoburocrática criada para dar objetividade ao processo seletivo da UnB, mostrou-se ser uma entidade potencialmente geradora de fortes tensões no cenário da antropologia contemporânea. Ao se colocar um antropólogo na comissão, designando-o como 'especialista no tema', houve o estabelecimento de pontes diretas entre antropologia e atividades de classificação racial a partir de atributos corporais com ares do que constituía a identidade da antropologia física que se praticava no final do século XIX e no início do século XX. (...) A dupla dose tipologia-prescrição não goza de prestígio na moderna reflexão antropológica. ${ }^{223}$

O artigo de Maio \& Santos ${ }^{224}$, citado acima, recebeu comentários de dezoito intelectuais $^{225}$ das áreas de genética, sociologia, história e antropologia social. Ainda que entre eles haja divergências quanto à implantação de cotas para negros nas universidades, eles concordam que o sistema de avaliação racial implantado pela UnB não é adequado.

\footnotetext{
${ }^{220}$ MAIO, Marcos Chor; SANTOS, Ricardo Ventura. Op. cit. p.199-200

${ }^{221}$ MAIO, Marcos Chor; SANTOS, Ricardo Ventura. Op. cit. p.202.

${ }^{222}$ MAIO, Marcos Chor; SANTOS, Ricardo Ventura. Op. cit. p.202

${ }^{223}$ MAIO, Marcos Chor; SANTOS, Ricardo Ventura. Op. cit. p.206-207.

${ }^{224}$ Lembremos que tanto Maio como Santos assinaram o manifesto "Cidadãos Anti-Racistas Contra as Leis Raciais", ou seja posicionam contra as cotas para negros.

${ }^{225}$ Horizontes Antropológicos, Porto Alegre, n.23, p. 215-291, jan/jun. 2005.
} 
Guimarães diz que o sistema de avaliação racial impinge constrangimento aos candidatos, além de os transformarem em alvos fáceis de discriminação. ${ }^{226}$ Para ele:

(...) a pertença a grupo racial é muitas vezes resultado de assunção pessoal, ainda que, em geral, seja resultado da estigmatização ou identificação por outros.(...) acho que a declaração de cor tem que ser respeitada em qualquer momento - esse é o princípio moral ${ }^{227}$

Observemos que a posição de José Jorge de Carvalho, um dos mentores do sistema de cotas na UnB é de contrariedade às fotografias, embora não por razões científicas, mas políticas:

Como Maio e Santos, sou contrário às fotos e minha razão por discordar delas não é 'científica', mas política: as fotos despolitizam o posicionamento do sujeito ao transferir a responsabilidade de assumir sua condição racial para a comissão. O que espero da autodeclaração é que ela se generalize especularmente, de modo a alcançar não somente os candidatos ao vestibular pelas cotas, mas também a nós, acadêmicos brancos que nunca nos assumimos como tais. ${ }^{228}$

Schwarcz lembra que a ciência, no exemplo da escola de Nina Rodrigues, buscava nos traços fisionômicos critérios suficientes de definição e hierarquização das raças ${ }^{229}$. Mesmo não sendo o caso de se debater esse momento do século XIX, o debate consiste no "retorno da crença na delimitação precisa de características fisiológicas e externas, como critério de definição, nesse caso, para a política de cotas para negros. ${ }^{230}$ Schwarcz critica o sistema da UnB:

No caso da UnB, descontadas as especificidades contextuais, os procedimentos parecem aparentados com os velhos critérios deterministas, no sentido de buscar em uma certa antropologia os 'especialistas das raças', e de escolher nos traços fisionômicos elementos objetivos e científicos para definir, ora quem, a identidade. ${ }^{231}$

${ }^{226}$ GUIMARÃES, Antônio Sérgio Alfredo. "Entre o medo de fraudes e o fantasma das raças". Horizontes Antropológicos, Porto Alegre, n.23, p. 215, jan/jun. 2005.

${ }^{227}$ Ibdem, p. 217.

${ }^{228}$ CARVALHO, José Jorge. "Usos e abusos da Antropologia em um contexto de tensão racial: o caso das cotas para negros na UnB". Horizontes Antropológicos, Porto Alegre, n.23, p. 244, jan/jun. 2005.

${ }_{229}$ SCHWARCZ, Lilia Moritz. "O retorno do objetivismo ou dos males de ser científico." Horizontes Antropológicos, Porto Alegre, n.23, p. 248, jan/jun. 2005.

${ }^{230}$ Idem, p. 249

${ }^{231}$ Ibdem, p. 249 
Para Schwarcz, a separação entre "verdadeiros e falsos negros", expõe os candidatos à condição de suspeitos:

O resultado é que, para além da organização de uma comissão de especialistas, do registro em fotos, da análise das mesmas fotos e da caracterização psicológica (nesse caso misturando critérios ainda mais díspares, como o pertencimento ou não ao movimento negro), os candidatos são expostos à própria condição de 'suspeitos'. ${ }^{232}$

Para a autora, o único critério possível de seleção é o da autodefinição, pois a raça é um construto social e nada vale retornar a um modelo pautado por critérios físicos, alçados à condição de científicos. ${ }^{233}$

Sansone critica a utilização de foto para aferir a cor do candidato, considerando o processo pouco inteligente e muito irritante. ${ }^{234}$ Mostra-se a favor das cotas e da autodeclaração, mesmo havendo algum abuso:

$\mathrm{Eu}$, muito a favor destas medidas de ação afirmativa, proponho que elas funcionem na base da autodeclaração - sabendo que haverá algum abuso, mas que a pressão moral para que as pessoas não se digam negras sabendo de não sê-lo funcionará como um eficiente incentivo. ${ }^{235}$

Rosário de Carvalho é contrária ao sistema de avaliação racial da UnB e manifesta-se a favor da autodeclaração:

(...) nenhuma tentativa de implantação de políticas redistributivas pode substituir, sob qualquer justificativa, a auto-adscrição por parte dos supostos beneficiários, outorgando a outrem uma prerrogativa que lhes é exclusiva. ${ }^{236}$

Rita Laura Segato também foi uma das mentoras do sistema de cotas da UnB. Cumpre lembrar, que nem ela nem José Jorge de Carvalho sugeriram no seu projeto o sistema de avaliação racial por fotografias.

\footnotetext{
${ }^{232}$ Ibdem, p. 249

${ }^{233}$ Ibdem, p.250.

${ }^{234}$ SANSONE, Lívio. "O bebê e a água do banho - a ação afirmativa continua importante, não obstante os erros da UnB!" Horizontes Antropológicos, Porto Alegre, n.23, p. 251, jan/jun. 2005.

${ }^{235}$ Idem, p. 252

${ }^{236}$ CARVALHO, Maria Rosário G. de.”Breves reflexões suscitadas pelo artigo Política de cotas raciais, os olhos da sociedade e os usos da Antropologia: o caso do vestibular da Universidade de Brasília (UnB)". Horizontes
} Antropológicos, Porto Alegre, n.23, p. 265, jan/jun. 2005. 
Segato faz uma crítica a Maio\&Santos devido ao posicionamento não explícito quanto à adoção ou não de cotas na universidade, porém implícito, sob a roupagem da cientificidade:

Se o exercício disciplinar deve, necessariamente, acompanhar a opinião para demonstrar que ela possui fundamento, isso, contudo, não autoriza os autores a omitir a explicitação da sua posição sobre o assunto e substituí-la pelo que é apresentado como exercício puramente disciplinar e neutro, a risco de que o resultado suscite a dúvida que estou justamente descrevendo: que se trata de um contrabando ideológico embrulhado no linguajar de aparência sistemática e laboratorial. ${ }^{237}$

Segato é a única ameniza a crítica ao sistema de avaliação racial da UnB, dizendo que o que importa no racismo à brasileira são os signos fenotípicos dos povos africanos escravizados, relacionados que estão com a subalternização devido à colonização:

(...) numa história particular como é a história da conquista e colonização da África, e da conseqüente escravização de parte de sua gente, o signo da pele negra é lido como diacrítico de pertencimento ao povo subalternizado por esses processos, e que isso nada tem a ver com quantidade ou tipo de genes. (...) Então, o racismo à brasileira fala disto: de que determinados signos fenotípicos tomam seu significado de uma história de guerra, escravização e, já neste século, sistemática exclusão, e que o que importa desses signos é somente seu impacto visual num código de leitura intensamente influenciado por essa história. ${ }^{238}$

Pena é enfático na sua contrariedade quanto ao sistema de avaliação racial da UnB:

Muitas asneiras têm sido ditas e escritas por políticos, professores e palpiteiros em geral. Mas certamente o festival atingiu níveis tsunâmicos com a decisão da Universidade de Brasília (UnB) de montar uma comissão para homologar a 'identidade racial' dos candidatos ao vestibular pela análise de fotografias. ${ }^{239}$

E, embora tenha assinado o manifesto "Cidadãos Anti-Racistas Contra as Leis Raciais", contra as cotas, Pena é a favor da autodeclaração:

O único critério admissível para as cotas é a autodeclaração. Se a UnB considera esse sistema suscetível a fraudes, pecou ao tentar corrigi-lo usando uma metodologia cientificamente inválida e socialmente ofensiva. ${ }^{240}$

\footnotetext{
${ }^{237}$ SEGATO, Rita Laura. "Em memória de tempos melhores: os antropólogos e a luta pelo direito". Horizontes Antropológicos, Porto Alegre, n.23, p. 273, jan/jun. 2005.

${ }^{238}$ Idem, p. 278.

${ }^{239}$ PENA, Sérgio D. J. "O triste caso do vestibular da universidade de Brasília”. Horizontes Antropológicos, Porto Alegre, n.23, p. 284, jan/jun. 2005.

${ }^{240}$ Idem, p. 285.
} 
Maggie é contra o sistema de avaliação racial da UnB, questiona a legitimidade da Antropologia para esse tipo de avaliação, e por fim, questiona a racialização:

as cotas raciais vieram para refazer o nosso sistema de classificação racial. Como instituir cotas raciais sem antes classificar rigidamente aqueles que têm direito e os que não têm?

(...)

Alguns (antropólogos) já decidiram que, para fazer justiça, faz-se necessário antes recriar a 'raça' e marcar os indivíduos de forma definitiva. Tentamos, no Brasil, ao longo do século XX, construir uma sociedade na qual os indivíduos podiam transitar entre marcas, ou até mesmo não se pensar a partir delas. O que essas políticas estão propondo é o fim dessa possibilidade e o início de uma marcação muito rígida de indivíduos, que não poderão mais dizer, que, tão-somente, pertencem à raça humana. ${ }^{241}$

Notamos que o posicionamento dos intelectuais acima citados é contrário às comissões de averiguação da identidade racial.

Vimos argumentos contrários à classificação racial, seja pelo caráter de "raça humana" à qual pertencemos, seja por causa da mestiçagem, que implica numa variada matiz de cores, vimos argumentos contrários às bancas de exame racial, e argumentos favoráveis à autodeclaração.

Investiguemos agora um ponto muito importante que é o da identidade. Para Taylor:

identidade designa algo como uma compreensão de quem somos, de nossas características definitórias fundamentais como seres humanos. A tese é de que nossa identidade é moldada em parte pelo reconhecimento ou por sua ausência, freqüentemente pelo reconhecimento errôneo por parte dos outros, de modo que uma pessoa ou grupo de pessoas pode sofrer reais danos, uma real distorção, se as pessoas ou sociedades ao redor deles lhes devolverem um quadro de si mesmas redutor, desmerecedor ou desprezível. ${ }^{242}$

Observamos que a identidade é como o indivíduo se define no mundo, numa relação dialógica, pois a maneira como ele é percebido pelo outro interfere na sua auto-percepção. Nesse sentido, a população negra ser mostrada pela mídia e pela escola em posição subalterna aos brancos, sem qualidades estéticas, estereotipada, e a população africana ser mostrada como tribos sem conhecimento científico, contribuem para uma imagem negativa dos negros, que vai se arraigando desde a infância, tanto nas crianças negras como nas brancas. Por outro

${ }^{241}$ MAGGIE, Yvonne. "Políticas de cotas e o vestibular da UnB ou a marca que cria sociedades divididas." Horizontes Antropológicos, Porto Alegre, n.23, p. 288 e 290, jan/jun. 2005.

${ }^{242}$ TAYLOR, Charles. Argumentos filosóficos. São Paulo: Edições Loyola, 2000, p.241. 
lado, a consciência e resistência a esse processo também fazem parte da construção da identidade. Conforme Duarte \& Guelfi:

Sob o rótulo 'negro' ou 'índio' havia, porém, uma diversidade cultural, pré-existente aos mecanismos identitários impostos pelas práticas e discursos europeus, que sobreviveu e se defrontou com tais mecanismos. Há um operação de resistência cultural que não cessou de se afirmar contra tais mecanismos. A resistência, ao contrário do que pode fazer crer essa palavra, estava presente na condição de existência, ou seja, de não se deixar construir segundo o discurso do outro. A identidade racial não foi, portanto, mera afirmação de uma diferença, vazia em si, pois os identificados racialmente compunham uma trajetória histórico-cultural distinta dos mecanismos de poder racializadores que estavam sendo implementados. ${ }^{243}$

Ou seja, quando um indivíduo se identifica como negro, afora os estereótipos negativos, há toda uma construção de resistência, auto-afirmação e orgulho. Quando uma banca examinadora diz ao indivíduo autodeclarado negro, que ele não é negro, está negando não apenas seu direito à ação afirmativa, mas também seu direito de vivenciar sua identidade. Além do mais, segundo Ferreira, a identidade está em constante transformação:

Importante é ressaltar que identidade não é vista, aqui, como uma categoria a expressar uma estrutura pessoal fixa, mantendo-se a mesma no tempo, como muitas teorias podem sugerir. É um constructo que reflete um processo em constante transformação, cujas mudanças vêm sempre associadas a mudanças de referências e a novas construções de realidade por parte dos indivíduos, determinadas por sua participação em certos processos provocadores de impacto existencial. ${ }^{244}$

Isso significa que indivíduos mestiços, em algum momento identificados como brancos, (em documentação, por exemplo), podem se descobrir identificados com o grupo negro, e reivindicar ser tratado como tal. Em outras palavras, a identidade tem historicidade, e a pessoa mais adequada para falar qual é sua identidade é o próprio indivíduo. Nesse sentido, é a declaração de Guimarães:

devo rever publicamente a minha primeira posição sobre esse ponto, tomada em 1996, quando sugeri que a declaração de cor fosse reintroduzida nos registros oficiais de modo a controlar mais facilmente a fraude; hoje, acho que a declaração de cor tem que ser respeitada em qualquer momento - esse é o princípio moral. ${ }^{245}$

243 DUARTE, Evandro C. Piza \& GUELFI, Warniley Pedroso. "Cotas raciais, política identitária e reivindicação de direitos" In: DUARTE, Evandro C. Piza, BERTÚLIO, Dora Lúcia de Lima e SILVA, Paulo Vinícius Baptista da (coords.). Cotas raciais no ensino superior. Curitiba: Juruá Editora, 2008, p. 146.

${ }^{244}$ FERREIRA, Ricardo Franklin. Afro-descendente - identidade em construção. São Paulo: EDUC; Rio de Janeiro: Pallas, 2004, p.46.

${ }^{245}$ GUIMARÃES, Antônio Sérgio Alfredo. "Entre o medo de fraudes e o fantasma das raças". Horizontes Antropológicos, Porto Alegre, n.23, p. 217, jan/jun. 2005. 


\section{A polêmica das cotas raciais}

As cotas raciais representam um tema muito controverso, o qual vem mobilizando muitos segmentos da sociedade, como intelectuais e a mídia.

\subsection{Os manifestos de 2006 e de 2008}

Exemplos dessa polêmica, são dois manifestos públicos que se posicionaram contra as cotas raciais, obtendo como resposta dois manifestos públicos a favor das cotas raciais, todos divulgados na imprensa.

O primeiro manifesto contra as cotas ocorreu em 2006. No dia 29-06-2006, foi divulgada na imprensa uma carta pública ${ }^{246}$, assinada por 101 intelectuais dirigida ao Congresso Nacional "pedindo-lhes que recusem o PL 73/1999 (Lei das Cotas) e o PL 3.198/2000 (Estatuto da Igualdade Racial) em nome da República democrática”. Título da carta: "Todos têm direitos iguais na República”.

No dia 04-07-2006, uma resposta foi dada à carta, divulgada também na imprensa ${ }^{247}$, por intelectuais a favor das cotas raciais, intitulada "Manifesto a favor da lei de cotas e do Estatuto de Igualdade Racial”.

Em 2008 outro manifesto anticotas foi feito, sendo entregue ao STF (Supremo Tribunal Federal), em 30-04-2008, pedindo a suspensão do sistema de cotas para negros nas universidades e do sistema ProUni. O manifesto intitulava-se "113 cidadãos anti-racistas contra as leis raciais". ${ }^{248}$ Conforme o manifesto, duas ações diretas de inconstitucionalidade (ADI 3.330 e ADI 3.197) promovidas pela Confenen (Confederação Nacional dos

\footnotetext{
${ }^{246}$ A carta pode ser encontrada na íntegra, no anexo 1, ou na íntegra com os respectivos signatários no site www1.folha.uol.com.br/folha/educação/ult305u18773.shtml, acesso em 10/09/2008

${ }^{247} \mathrm{O}$ manifesto pode ser encontrado na íntegra, no anexo 2 ou na íntegra, com os respectivos signatários, no site: www1.folha.uol.com.br/folha/educação/ult305u18773.shtml, acesso em 10/09/2008

${ }^{248} \mathrm{O}$ manifesto pode ser encontrada na íntegra, no anexo 3, ou na íntegra com os respectivos signatários no site www1.folha.uol.com.br/folha/educação/ult305u401519.shtml, acesso em 10/09/2008
} 
Estabelecimentos de Ensino), a primeira contra o programa ProUni e a segunda contra a lei de cotas nos concursos vestibulares das universidades estaduais do Rio de Janeiro, serão apreciadas proximamente pelo STF.

Novamente um grupo favorável às cotas também divulgou um manifesto, entregando-o em 13-05-2008, ao ministro Gilmar Mendes, presidente do STF. O manifesto intitulava-se "Manifesto em defesa da justiça e constitucionalidade das cotas"249.

O "Manifesto em defesa da justiça e constitucionalidade das cotas" diz que os signatários do manifesto "113 cidadãos anti-racistas contra as leis raciais", são basicamente acadêmicos: "80 deles são professores universitários e pesquisadores, desses 80, apenas um é negro. Representam, portanto, uma pequena parte da elite acadêmica branca centrada no eixo Rio de Janeiro-São Paulo (...) Eles não falam nem mesmo pela maioria dos professores das instituições de onde se originam. Por outro lado, não resta dúvida de que este grupo não representa nem minimamente a comunidade negra brasileira. As associações civis, culturais e religiosas negras, os vários setores do movimento negro organizado, os pesquisadores, docentes e estudantes negros, todos em sua esmagadora maioria assinam o nosso manifesto."

Passemos a estudar os argumentos contra as cotas e a favor das cotas raciais, nas instituições de ensino superior.

\footnotetext{
${ }^{249}$ Podem ser encontrados trechos do manifesto divulgados pelo jornal Folha de São Paulo, em 14/05/2008, p. C5 no anexo 4, ou na íntegra com os respectivos signatários no site http://media.folha.uol.com.br/cotidiano/2008/05/13/stf_manifesto_13_maio_2008.pdf, acesso em 10/09/2008.
} 


\subsection{Argumentos contra as cotas raciais e a favor das cotas raciais nas instituições públicas de ensino superior}

Podemos citar os seguintes argumentos contra as cotas raciais:

1.Não é possível definir quem é negro

2.As cotas raciais são inconstitucionais

3.Em vez de cotas raciais, deve-se investir em políticas universalistas

4.As cotas atentam contra a meritocracia

5. As cotas prejudicam a excelência na universidade

6.As cotas racializam o país, criando o ódio racial

7. As cotas humilham os negros

Examinemos esses argumentos um a um e os contra-argumentos.

\section{Não é possível definir quem é negro}

Aqueles que argumentam contra as cotas dizem que no Brasil não é possível definir quem é negro. Já vimos em tópico anterior a contrariedade de intelectuais quanto a comissões de avaliação e a preferência pela autodeclaração. Não podemos esperar que esse tipo de polêmica se resolva para iniciarmos políticas em favor da população negra. Investiguemos, na prática, como os gestores das universidades públicas vêm lidando com essa questão.

Alguns gestores das universidades exigem autodeclaração, outros exigem documentação comprobatória, outros incluem a expressão "sob as penas da lei" na autodeclaração, e outros utilizam-se de comissões de averiguação.

A Universidade Federal de São Paulo - UNIFESP, exige documentação comprobatória no ato de matrícula. Segundo o Manual do vestibular UNIFESP-2009, no ato da matrícula "Os candidatos cotistas deverão apresentar documento expedido por órgão oficial tais como: 
certidão de nascimento, cédula de identidade, certificado militar ou Certidão de Prontuário (obtida no Instituto de Identificação), que comprove sua condição de cor (ou raça) preta, parda ou indígena." 250

A Universidade Federal de São Carlos - UFSCar, solicita autodeclaração, porém, recomenda que os alunos providenciem "documentos como prontuário do alistamento militar, registro de nascimento, ou o prontuário de identificação civil, dele próprio ou de seus ascendentes diretos (pai ou mãe), ou ainda outros documentos dotados de fé pública no qual esteja consignada cor diversa de branca, amarela ou indígena." ${ }^{251}$ A não apresentação da documentação, no caso de decisão do PróReitor de Graduação ou de dúvida suscitada por terceiros implicará na perda do direito de ingresso por reserva de vagas destinadas a negros (pretos ou pardos).

A Universidade do Rio Grande do Sul - UFRS, exige que os candidatos negros assinem uma autodeclaração étnico-racial, sujeito a penalidades legais. A desclassificação do Concurso Vestibular e a matrícula recusada, poderá acontecer a qualquer tempo. Vejamos o modelo de autodeclaração $^{252}$ :

\footnotetext{
${ }^{250}$ Consulta na internet endereço http://www.unifesp.br/prograd/vestibular/portal/index.php?option=com_content\&task=view\&id=107\&Itemid=2, acesso em 08-11-2008.

${ }^{251}$ Art. 18 da Portaria CEPE 586/2008, consulta na internet endereço

http://www.vunesp.com.br/vestibulares/ufsc0802/edital_ufsc0802.pdf, acesso em 08-11-2008.

${ }^{252}$ Edital de abertura de inscrições - 2009, consulta na internet, endereço http://www.vestibular.ufrgs.br/cv2009/EDITAL_DE_ABERTURA_DE_INSCRICOES_FINAL2009.doc, acesso em 08-11-2008
} 


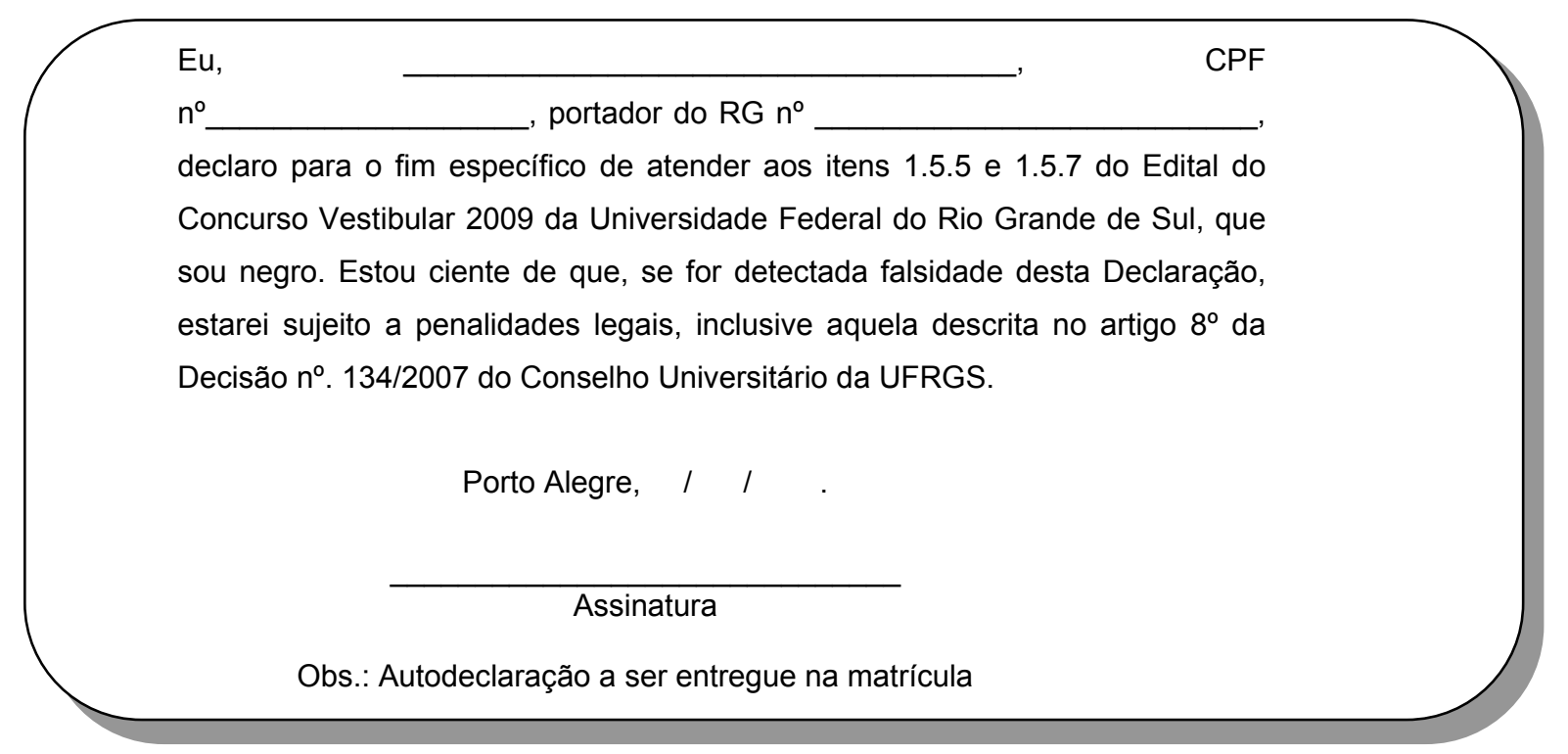

Artigo $8^{\circ}$ da Decisão no $.134 / 2007$ do Conselho Universitário da UFRGS:

Art. $8^{\circ}$ - $\mathrm{O}$ candidato que prestar informações falsas relativas às exigências da presente Decisão estará sujeito, além da penalização pelos crimes previstos em lei, à desclassificação do Concurso Vestibular ou dos processos seletivos dos cursos técnicos e ter, em conseqüência, sua matrícula recusada no curso, o que poderá acontecer a qualquer tempo. ${ }^{253}$

A Universidade Estadual do Rio de Janeiro (UERJ) e a Universidade Estadual do Norte Fluminense (UENF) também submetem o candidato às penas da lei, na autodeclaração:

De acordo com a Lei Estadual $n^{\circ} 4151 / 2003$, eu (nome completo), inscrito no Vestibular Estadual 2009 , sob o ${ }^{\circ}$ (inscrição), declaro, sob as penas da lei, identificar-me como negro.

(data e assinatura do candidato) ${ }^{254}$

Mas o que significa "sob penas da lei”? A autodeclaração da Universidade Estadual de Mato Grosso - UNEMAT inclui o parágrafo:

Declaro estar ciente que informações prestadas e que não correspondam à verdade dos fatos implicarão no cancelamento da matrícula, em caso de aprovação, e instauração do correspondente processo, conforme o artigo 299 do Código Penal. ${ }^{255}$

\footnotetext{
${ }^{253}$ DECISÃO No 134/2007, consulta na internet endereço http://www.ufrgs.br/consun/leis/Dec134-07.htm, acesso 08-11-2008.

${ }^{254}$ Consulta na internet, endereço http://www.vestibular.uerj.br/vest2009/files/Anexo_3_ED.pdf, acesso 08-112008.
} 
O artigo 299 do Código Penal diz o seguinte:

"Art. 299. Omitir, em documento público ou particular, declaração que dele devia constar, ou nele inserir ou fazer inserir declaração falsa ou diversa da que devia ser escrita, com fim de prejudicar direito, criar obrigação ou alterar a verdade sobre fato juridicamente relevante:

Pena: reclusão, de 1 (um) a 5 (cinco) anos, e multa, se o documento é público e reclusão de 1 (um) a 3 (três) anos, e multa, se o documento é particular."

Apesar dessas medidas de segurança, continua a dúvida de como avaliar se o candidato fraudou a autodeclaração. Tentando sanar essa dúvida, algumas universidades fazem uma avaliação fenotípica do candidato, por foto ou entrevista. Vejamos alguns exemplos.

Na Universidade Federal de Santa Catarina - UFSC, o candidato autodeclarado negro, no ato da matrícula passa por uma entrevista pela Banca de Validação da Autodeclaração. Só são aceitos os candidatos que "tenham traços fenotípicos que os caracterizam na sociedade como pertencentes ao grupo racial negro; não se enquadram nessa situação os candidatos que não tenham traços fenotípicos que os identificam com o grupo racial negro, ainda que tenham algum ascendente negro" ${ }^{256}$. Se a Banca de Validação não validar a autodeclaração o candidato perderá a vaga.

A Universidade Federal do Paraná também tem uma Banca de Validação e Orientação da Autodeclaração. Conforme RESOLUÇÃO No 37/04-COUN, há uma definição para quem é considerado negro: "Serão considerados negros, para os efeitos desta Resolução, os candidatos

\footnotetext{
${ }^{255}$ Consulta na internet, endereço

http://www.unemat.br/vestibular/downloads/vest_2009_1/documentos/vestibular_2009_1_manual_candidato.pdf, acesso em 08-11-2008

${ }^{256}$ Consulta na internet endereço: http://www.vestibular2009.ufsc.br/PAA_orientacoes_basicas.pdf, acesso em 08-11-2008.
} 
de cor preta ou parda, que possuam os traços fenotípicos que os caracterizem como pertencentes ao grupo racial negro.",257

Conforme a Universidade Estadual de Londrina - UEL, "considera-se negro quem possuir pele de cor preta ou parda” ${ }^{\text {258 }}$. Haverá uma comissão para homologar a matrícula dos candidatos que se autodeclararem negros, após verificada essa condição. ${ }^{259}$

A Universidade de Brasília realizará entrevista pessoal, que decidirá se o candidato concorrente às vagas para negros corresponde aos requisitos, em quantidade de até duas vezes o número de vagas oferecidas por curso. ${ }^{260}$ "Verificado pela Banca Entrevistadora que o candidato submetido à entrevista pessoal não preenche os requisitos estabelecidos neste edital, passará ele a concorrer apenas às vagas oferecidas pelo Sistema Universal."261 Notamos que a UnB deixou de avaliar os candidatos por fotografias.

Já a Universidade Federal do Maranhão - UFMA, solicita uma fotografia colorida 5x7. Há uma Comissão de Validação da Opção de Cotas, que realiza entrevistas no caso de dúvidas. "Caso a Universidade confirme que as informações prestadas não são verdadeiras, o (a) candidato (a) estará automaticamente eliminado do PSV 2009 e, caso as informações sejam confirmadas como falsas após o (a) candidato (a) estar aprovado (a) e matriculado (a) na UFMA, sua matrícula acadêmica será automaticamente cancelada."262

A Universidade Estadual de Mato Grosso do Sul - UEMS, também solicita uma foto $5 \times 7$. Os optantes ao sistema de cotas para negros podem ter a inscrição indeferida "por não

\footnotetext{
${ }^{257}$ Consulta na internet, endereço http://www.ufpr.br/soc/pesquisa.php? conselho= \&item=Resultado da Pesquisa\&searchword=cotas, acesso 08-11-2008

${ }^{258}$ Consulta na internet, endereço http://www.uel.br/prograd/divisao-politicasgraduacao/resolucao_cu_2004_78.pdf, acesso em 08-11-2008

${ }^{259}$ Idem

${ }^{260}$ Consulta na internet, endereço

http://www.cespe.unb.br/vestibular/1VEST2009/arquivos/ED_3_2008_1_VEST_2009_ABT_FINAL_FORM.PD F, acesso 08-11-2008

261 idem

262 Consulta na internet, endereço http://www.ufma.br/editais/arquivos/edital_proen_psv_2009.pdf, acesso em 08-11-2008.
} 
apresentarem as características relativas ao fenótipo", concorrendo automaticamente nos $70 \%$ (setenta) por cento, reservado as vagas gerais. ${ }^{, 263}$.

$\mathrm{Na}$ Universidade Estadual de Ponta Grossa, há uma banca de Constatação da Condição de Negro para confirmar o direito à matrícula dos que apresentam traços físicos característicos do grupo étnico negro. "Considera-se negro o candidato que assim se declarar e apresentar traços físicos característicos deste grupo étnico."264

Notamos por esses exemplos que gestores de universidades públicas vêm buscando mecanismos para inibir a fraude, e algumas universidades definem quem é negro por características fenotípicas. Sempre serão questionáveis os critérios fenotípicos que determinada banca utiliza para avaliar um candidato, sobretudo aqueles mestiços. Na Administração Pública, os gestores traçam estratégias para alcançar os objetivos. Nesse sentido, talvez seja útil uma banca examinadora se o índice de fraudes for alto. No entanto, para os Direitos Humanos, a autodeclaração é o único critério que respeita o direito do indivíduo à diferença e à identidade. A identidade caracteriza-se por ser mutável, e o próprio indivíduo é o mais indicado para conhecê-la.

\section{As cotas raciais são inconstitucionais}

A carta "Todos têm direitos iguais na República”, de 29-06-2006, opõe-se ao sistema de cotas argumentando que as cotas ferem o preceito da igualdade de todos perante a lei, conforme artigo $5^{\circ}$, da Constituição: “O princípio da igualdade política e jurídica dos cidadãos (...) encontra-se ameaçado de extinção (...) Se forem aprovados, (os pontos do Estatuto de Igualdade Racial) a nação brasileira passará a definir os direitos das pessoas com base na tonalidade da sua pele, pela raça. (...) as possíveis conseqüências das cotas raciais

\footnotetext{
${ }^{263}$ Consulta na internet, endereço http://www.vestibular.uems.br/documentos/editais/edital_negros.pdf, acesso 09-11-2008.

264 RESOLUÇÃO UNIV No 9, DE 26 DE ABRIL DE 2006, consulta na internet, endereço http://www.uepg.br/cps/Documentos/2008/manves092.pdf, acesso 09-11-2008.
} 
transformam classificações estatísticas gerais (como as do IBGE) em identidades e direitos individuais contra o preceito da igualdade de todos perante a lei."

Contra-argumentando, os adeptos das cotas raciais na carta "Manifesto a favor da lei de cotas e do Estatuto de Igualdade Racial", de 04-07-2006 dizem que "o Estatuto transforma em ação concreta os valores de igualdade plasmados na Constituição de 1988, claramente pró-ativa na sua afirmação de que é necessário adotar mecanismos capazes de viabilizar a igualdade almejada” e "a igualdade universal dentro da República não é um princípio vazio, e sim uma meta a ser alcançada”. Ou seja, contrapõem ao princípio da igualdade formal o princípio da igualdade material, respaldando-se na própria Constituição, deixando claro o caráter legal das cotas.

Em 30-04-2008, o manifesto "113 cidadãos anti-racistas contra as leis raciais" utiliza como argumento contra as cotas raciais, artigos da Constituição, como o artigo 19, que diz: "É vedado à União, aos Estados, ao Distrito Federal e aos Municípios criar distinções entre brasileiros ou preferências entre si”; e o artigo 208, inciso V que diz: "O dever do Estado com a educação será efetivado mediante a garantia de acesso aos níveis mais elevados do ensino, da pesquisa e da criação artística, segundo a capacidade de cada um."

Outro argumento do manifesto refere-se à igualdade material praticada na constituição em relação aos deficientes físicos e mulheres. O manifesto concorda com essas ações afirmativas, mas diz que não devem se estender a critérios raciais, pois raças não existem, para o tanto, vale-se de justificações genéticas.

Ora, ao concordar com a prática da igualdade material em relação aos deficientes físicos e às mulheres, o manifesto "113 cidadãos anti-racistas contra as leis raciais" está admitindo que a Constituição deve ser analisada no seu contexto, logo o artigo 19 não pode ser tomado ao pé da letra, e sim considerado no corpo da Constituição. Quanto ao artigo 208, inciso V, da seção referente à Educação, devemos nos atentar ao artigo 206, inciso I, da mesma seção que diz: "O ensino será ministrado com base nos seguintes princípios: I. igualdade de acesso e permanência na escola”. Ou seja, as cotas não ferem a garantia de acesso à educação conforme a capacidade de cada um porque a própria Constituição atenta para o princípio de 
igualdade de condições para o acesso e permanência na escola. As cotas buscam justamente essa igualdade de condições.

Quanto ao argumento de que raças não existem, o "Manifesto em defesa da justiça e constitucionalidade das cotas", de 13-05-2008, conclui: "Os argumentos genéticos são invocados ainda na tentativa de desqualificar a reivindicação por reparações aos descendentes de escravos no Brasil. Daí chegarem a afirmar que 'não é legítimo associar cores de pele a ancestralidades e que as operações de identificação de 'negros' com descendentes de escravos e com 'afrodescendentes' são meros exercícios da imaginação ideológica'. Não é legítimo em que sentido? Se uma pessoa negra é vítima de racismo e se tivemos um passado de 350 anos de escravidão, é mais do que legítimo tentar eliminar a obra da escravidão, que é discriminação sofrida até hoje pelos que portam a aparência física dos africanos escravizados."

\section{Em vez de cotas raciais, deve-se investir em políticas universalistas}

Em geral, os adversários das cotas argumentam que em vez de cotas raciais, deve-se investir em políticas universalistas, como melhorar o ensino básico.

O manifesto "113 cidadãos anti-racistas contra as leis raciais", contrário às cotas, utiliza a argumentação de que a desigualdade nos vestibulares advém da pobreza, que tem

todas as cores, logo, “apresentadas como maneira de reduzir as desigualdades sociais, as cotas raciais não contribuem para isso, ocultam uma realidade trágica e desviam as atenções dos desafios imensos e das urgências, sociais e educacionais, com os quais se defronta a nação”. Ou seja, conforme esse argumento, as cotas raciais não resolvem os problemas de desigualdade e ocultam a necessidade de resolvê-los.

Duarte argumenta que toda política focal em etnias é antiuniversalista: 
(...) toda política compensatória por reservas étnicas é antiuniversalista e apunhala no coração as esperanças de implantação de um regime verdadeira e amplamente democrático em nossa nação. ${ }^{265}$

Este argumento não corresponde à realidade, pois políticas focais não excluem políticas universalistas, e os proponentes das cotas raciais alertam para a necessidade de políticas universalistas, como melhorar o ensino básico. Eles alegam, no entanto, que políticas universalistas demoram para ser implementadas e surtirem seus efeitos e não combatem a desigualdade racial.

O "Manifesto em defesa da justiça e constitucionalidade das cotas", diz que os contrários às cotas "ignoram a correlação sistemática que todos os estudos estatísticos indicam entre linhas de cor e curvas de pobreza, bem como que as cotas promovem também os outros segmentos de população discriminados pelo atual sistema de acesso ao ensino superior."

A idéia principal das políticas universalistas é que, incluindo os pobres, estaria resolvendo o problema da maioria dos negros. Segundo a publicação "Cotas raciais: por que sim? " isso não é verdade, pois:

\begin{abstract}
Mesmo entre os pobres, assistiríamos a uma maior inclusão dos(as) brancos(as). Na maioria dos casos, as escolas públicas como particulares não mostram as pessoas negras como agente de uma história anterior a sua chegada ao Brasil. A rica contribuição histórica e cultural dessa população não é trabalhada em sala. Desde sempre, as crianças, negras ou não, aprendem a ver o(a) negro(a) de uma forma negativa. A diferença é que, para as crianças negras, o impacto é maior: sua autoestima fica comprometida pela ausência de modelos negros. Ou seja, a escola não dispõe de uma estrutura que valorize a população negra fazendo com que as crianças negras, mesmo recebendo ensino de 'boa qualidade', ainda assim apresentem resultados mais baixos que colegas de classe brancos(as). ${ }^{266}$
\end{abstract}

Comparando brancos e negros de escolas públicas, Carvalho lembra que os brancos estão em vantagem, pois "têm uma maior riqueza familiar e um maior capital, cultural e de autoconfiança"267.

265 DUARTE, Luiz Fernando Dias. "Pungente retrato do universalismo apunhalado". Horizontes Antropológicos, Porto Alegre, n.23, p. 256, jan/jun. 2005, p. 256.

${ }^{266}$ LOPES, Cristina (org.). Cotas raciais: Por que sim? Rio de Janeiro: Ibase: Observatório da Cidadania, 2006, p. 33-34. Consulta na internet, www.ibase.br/userimages/ibase_cotas_raciais_2.pdf, acesso em 28-6-2008.

${ }^{267}$ CARVALHO, José Jorge de. Inclusão Étnica e Racial no Brasil - a questão das cotas no ensino superior. São Paulo: Attar, 2006, p. 59. 
Em síntese, a razão para políticas focais raciais (sem exclusão das políticas universais) é a desigualdade racial apontada pelas estatísticas e que são causadas por razões históricas e razões presentes, como a discriminação racial e o racismo que atuam na sociedade. $\mathrm{O}$ fato de existirem a discriminação racial e racismo é justificativa suficiente para a utilização de políticas raciais compensatórias. Mesmo aqueles que tentam minimizar a presença do racismo acabam reconhecendo sua existência:

Ali Kamel, intitula seu livro "Não somos racistas - uma reação aos que querem nos transformar numa nação bicolor" 268 . Embora o título destaque em letras garrafais "Não somos racistas”, no decorrer do livro, Kamel admite várias vezes que há racismo no Brasil. Kamel admite a existência do racismo em trechos como:

Como diz Peter Fry, a democracia racial, longe de ser uma realidade, era um alvo a ser buscado permanentemente. (...) Isso jamais implicou deixar de admitir que aqui no Brasil existia o racismo. É evidente que ele existia e existe, porque onde há homens reunidos há também todos os sentimentos, os piores inclusive. ${ }^{269}$

De outras formas, admite que existe racismo no Brasil, porém somos menos racistas e esse racismo seria menos nocivo, pois seria um racismo "envergonhado":

Mas a nossa principal diferença em relação aos americanos não é apenas porque aqui, quando existe, o racismo se revela de maneira menos óbvia. A nossa diferença é que aqui, não há como negar, há um menor número dessa gente odiosa, os racistas. (...) O que nos faz diferentes é que aqui, indubitavelmente, há menos racismo e, quando há, ele é envergonhado, porque tem consciência de que a sociedade de modo geral condena a prática como odiosa. 270

Admitindo o racismo, procura diminuir sua importância, alegando não ser um traço dominante da nossa cultura, nem marca da nossa identidade:

O racismo sempre é de pessoas sobre pessoas, e ele existe aqui como em todas as partes do mundo. Mas não é um traço dominante da nossa cultura. ${ }^{271}$

\footnotetext{
${ }^{268}$ KAMEL, Ali. Não somos racistas - uma reação aos que querem nos transformar numa nação bicolor. Rio de Janeiro : Nova Fronteira, 2006.

${ }^{269}$ idem, p. 19-20

${ }^{270}$ idem, p. 22-23

${ }^{271}$ idem, p. 66
} 
E:

O mal deste país não é o racismo. Ele existe aqui, como em todo lugar, mas, entre nós, nem de longe se transformou na marca de nossa identidade. ${ }^{272}$

O importante a ser destacado nesses exemplos, é que numa obra que chama a atenção pelo título "Não somos racistas", o autor admite o racismo, ainda que procurando nos tornar "menos racistas". Dois pontos se destacam nessas afirmações. Primeiro, há uma contradição, pois o autor vai se posicionar contra as cotas para negros, sustentando que as desvantagens de negros em relação aos brancos não é o racismo, mas a pobreza, e que para combatê-la, devemos utilizar políticas universalistas, enfatizando a melhoria o ensino público. Mas, se Kamel admite que há o racismo, e sabemos que o racismo é fonte de desvantagem, não está justificada a existência de cotas, como forma de reparação das desvantagens produzidas pelo racismo? Segundo, o que significa sermos "menos racistas", ou o racismo não ser nossa "marca"? Uma vez que o racismo existe, não estamos imunes aos seus efeitos nefastos. Além disso, sendo "menos racistas", como medir os efeitos menos perniciosos? E seria o dito "racismo envergonhado" menos danoso, ou seus efeitos discriminatórios podem ser tão efetivos como o racismo declarado? Talvez o racismo envergonhado seja na verdade mais perigoso, pois é mais difícil de ser identificado e combatido. Quanto a essa questão Kamel utiliza um frase de efeito, dizendo que o racismo explícito oprime sem pudor, enquanto o racismo envergonhado deixa de oprimir pelo pudor ${ }^{273}$. Concordar com essa frase seria dizer que uma vez o racismo existindo, ele pode existir em tal forma (a envergonhada) que não implique em opressão. Mas se o racismo existe, ele já produz seus efeitos, que sejam o de olhar o semelhante, (no caso o indivíduo negro), e considerá-lo inferior, duvidar de sua humanidade, julgá-lo por meio de estereótipos. Supor que tais efeitos não produzam resultados é supor que o ser humano não se guia por seu ideário.

Logo, enquanto existir racismo, estaremos sujeitos aos seus efeitos, na forma de comportamentos explícitos ou implícitos (mais difíceis de combater), e as políticas

\footnotetext{
272 idem, p. 78

${ }^{273}$ idem, p. 20
} 
compensatórias focadas na raça para combater essa desvantagem social mostram-se concernentes com a justiça social.

\section{As cotas atentam contra a meritocracia}

A meritocracia prevê que numa competição, vence o candidato com mais mérito, ou seja, melhor desempenho. Os defensores da meritocracia defendem que as condições do vestibular deve ser as mesmas para todos e são contrários às cotas porque elas aprovariam pessoas com notas inferiores às notas de outros que ficariam fora do vestibular. Conforme Goldemberg \& Durham:

A instituição do exame vestibular consiste numa vitória democrática contra as pragas do protecionismo, do clientelismo e do racismo que permeiam a sociedade brasileira. O ingresso depende exclusivamente do desempenho dos alunos em provas que medem razoavelmente bem a preparação, as competências e as habilidades dos candidatos que são necessárias para o bom desempenho num curso de nível superior. Alunos de qualquer raça, nível de renda e gênero são reprovados ou aprovados exclusivamente em função de seu desempenho. (...) A solução de cotas não se encaminha no sentido de propor uma ação afirmativa que permita aos brasileiros com ascendência africana superar deficiências do seu processo de escolarização e o estigma da discriminação, mas a de reivindicar que, para os 'negros', os critérios de admissão sejam menos rigorosos. ${ }^{274}$

O questionável, nesse caso, são as condições da competição. Se numa corrida de cem metros, alguns corredores saem metros à frente, obviamente terão vantagem no resultado. A instituição do vestibular mede desempenho de candidatos que competem em condições diversificadas. Infelizmente o ensino público no nível fundamental e médio apresenta pior qualidade que o ensino privado, logo, aqueles que podem pagar boas escolas particulares têm vantagem sobre os alunos de escola pública. Também aqueles que podem pagar cursinhos prévestibulares caros têm mais chance de entrar nas disputadas vagas do ensino superior público, principalmente nas carreiras de maior procura. Dessa maneira, maior poder aquisitivo resulta em maior chance de passar no vestibular.

Na opinião de Frei David:

${ }^{274}$ GOLDEMBERG, José e DURHAM, Eunice R. Cotas nas universidades públicas. In: FRY, Peter, MAGGIE, Ivone, MAIO, Marcos Chor, MONTEIRO, Simone e SANTOS, Ricardo Ventura (org.). Divisões Perigosas. Rio de Janeiro: Civilização Brasileira, 2007, p.151-152. 
A meritocracia é uma forma de corrupção disfarçada que setores da sociedade brasileira usam para desviar o dinheiro público para "os mesmos". Como? Se colocarmos duas pessoas para disputar uma corrida, e para uma dermos acesso aos melhores treinadores, a uma boa alimentação, a equipamento técnico e deixarmos a outra abandonada à própria sorte, quem vai ser a vencedora? Assim é a universidade pública: ela sabe que um setor foi privilegiado no acesso ao acúmulo de saber. As universidades partem de uma falsa igualdade e têm a coragem de dizer que os que entram, o fazem por mérito, pois prestaram o mesmo vestibular. ${ }^{275}$

Além das condições diferentes de competição, há questionamentos quanto ao conteúdo dos vestibulares, se estariam realmente medindo a capacidade do candidato, ou um conteúdo adquirido para aquela prova especificamente, o que favoreceria os que tiveram acesso ao melhor preparo. Conforme Frei David:

O conteúdo dos vestibulares públicos corre o perigo de ser conteúdo descartável. Passa a ser uma excelente ferramenta para eliminar os pobres e afro-descendentes, que não tiveram acesso a conteúdos complexos e cheios de 'macetes' ministrados nos cursinhos caros, mas têm capacidade, que não é medida pelos vestibulares. ${ }^{276}$

\section{As cotas prejudicam a excelência na universidade}

Os adversários das cotas argumentam que os alunos cotistas estariam menos preparados para o ingresso na universidade, o que afetaria a qualidade discente da universidade. Na época da implantação de cotas na UERJ, segundo Freire, mesmo sem cotas, alunos ingressarem com baixos escores não era novidade:

Há anos que, em função desse sistema [o vestibular], recebemos alunos que obtiveram, algumas disciplinas no exame vestibular, grau apenas diferente de zero. Não será o sistema de cotas que inaugurará na universidade brasileira a presença de estudantes que trazem graves deficiências desde o ensino médio. Já trabalhamos com esta condição há anos, e não só com alunos das escolas públicas. Os dados do ENEM não permitem omitir esta situação. O problema é que, enquanto isso só acontecia nos cursos vistos como de 'baixo prestígio social', parece que ninguém se incomodava. Será que a formação de professores é menos importante que a formação de odontólogos? ${ }^{277}$

${ }^{275}$ SANTOS, Frei David Raimundo. Cotas: atos de exclusão substituídos por atos de inclusão? In: PAIVA, Ângela Randolpho org. Ação Afirmativa na universidade: reflexão sobre experiências concretas Brasil Estados Unidos. Rio de Janeiro: Editora PUC-Rio, 2004, p.183-184.

${ }^{276}$ Idem, p. 185

${ }^{277}$ FREIRE, Nilcéa. A experiência da Universidade do Estado do Rio de Janeiro (UERJ) na implantação de cotas para ingresso na universidade. In: PAIVA, Ângela Randolpho org. Ação Afirmativa na universidade: reflexão sobre experiências concretas Brasil - Estados Unidos. Rio de Janeiro: Editora PUC-Rio, 2004, p.191192. 
O fato é que as pesquisas que foram feitas com alunos cotistas a respeito do seu desempenho acadêmico mostram que a diferença entre os resultados dos alunos cotistas e dos alunos que ingressaram pelo sistema universal não é significativa.

Cardoso estudou o desempenho dos alunos da UnB ingressantes em 2006 e chegou aos seguintes resultados (as notas na UnB correspondem a menções cujos equivalentes numéricos variam de 0 a5):

Tabela 1- Média dos rendimentos no primeiro semestre de curso e diferenças entre cotistas e não-cotistas (\%), UnB $2006^{278}$

\begin{tabular}{|c|c|c|c|c|}
\hline $\begin{array}{l}\text { Área do } \\
\text { curso }\end{array}$ & $\begin{array}{ll}\quad \text { Grupo } & \text { de } \\
\text { prestígio } & \text { do } \\
\text { curso } & \end{array}$ & $\begin{array}{l}\text { Sistema } \\
\text { de seleção }\end{array}$ & $\begin{array}{l}\text { Média de } \\
\text { rendimento }\end{array}$ & Diferença \\
\hline \multirow{4}{*}{ Humanidades } & \multirow{2}{*}{$\begin{array}{l}\text { Maior } \\
\text { prestígio }\end{array}$} & Universal & 3,95 & \multirow[t]{2}{*}{$6 \%$} \\
\hline & & Cotas & 3,72 & \\
\hline & \multirow{2}{*}{$\begin{array}{l}\text { Menor } \\
\text { prestígio }\end{array}$} & Universal & 3,89 & \multirow[t]{2}{*}{$-1 \%$} \\
\hline & & Cotas & 3,92 & \\
\hline \multirow{4}{*}{ Ciências } & \multirow{2}{*}{$\begin{array}{l}\text { Maior } \\
\text { prestígio }\end{array}$} & Universal & 3,49 & \multirow[t]{2}{*}{$11 \%$} \\
\hline & & Cotas & 3,13 & \\
\hline & \multirow{2}{*}{$\begin{array}{l}\text { Menor } \\
\text { prestígio }\end{array}$} & Universal & 3,18 & \multirow[t]{2}{*}{$-2 \%$} \\
\hline & & Cotas & 3,25 & \\
\hline \multirow{4}{*}{ Saúde } & \multirow{2}{*}{$\begin{array}{l}\text { Maior } \\
\text { prestígio }\end{array}$} & Universal & 3,89 & \multirow[t]{2}{*}{$2 \%$} \\
\hline & & Cotas & 3,83 & \\
\hline & \multirow{2}{*}{$\begin{array}{l}\text { Menor } \\
\text { prestígio }\end{array}$} & Universal & 3,68 & \multirow[t]{2}{*}{$4 \%$} \\
\hline & & Cotas & 3,53 & \\
\hline \multirow{2}{*}{\multicolumn{2}{|c|}{ Total UnB }} & Universal & 3,71 & \multirow[t]{2}{*}{$3 \%$} \\
\hline & & Cotas & 3,59 & \\
\hline
\end{tabular}

Fonte: Cespe/UnB, elaboração de Claudete Batista Cardoso

${ }^{278}$ CARDOSO, Claudete Batista. Efeitos da Política de Cotas na Universidade de Brasília: uma análise do rendimento e da evasão. Dissertação de Mestrado, Universidade de Brasília, 2008, p.87. 
Notamos pelos dados que os alunos de humanidades nos cursos de maior prestígio, ingressantes no sistema universal tiveram desempenho $6 \%$ maior que os ingressantes por cotas. Nos cursos de menor prestígio, os cotistas ultrapassaram os não-cotistas em 1\%. Na área de Ciências, nos cursos de maior prestígio, os não-cotistas ultrapassaram os cotistas em 11\% e nos cursos de menor prestígio os cotistas ultrapassaram os não-cotistas em $2 \%$. Na área de saúde, nos cursos de maior prestígio os não-cotistas ultrapassaram os cotistas em $2 \%$ e nos de menor prestígio ultrapassaram em $4 \%$. As diferenças são muito pequenas, com exceção talvez dos cursos de ciências de maior prestígio, onde a diferença a favor dos cotistas foi de $11 \%$. No total, a diferença entre as notas corresponde a 3\%, a favor dos não-cotistas. Essas variações pequenas corroboram a idéia de que o desempenho acadêmico dos cotistas não difere significativamente do desempenho acadêmico dos não-cotistas.

Citemos um segundo exemplo, o desempenho dos alunos cotistas e não-cotistas da UFBA (Universidade Federal da Bahia), referente aos dois semestres de 2005. Como podemos observar pelos dados da tabela abaixo, dos 18 cursos de maior concorrência, os cotistas obtiveram em onze deles (61\%), coeficientes de rendimento iguais ou melhores que os nãocotistas: 
Tabela 2 - Distribuição percentual dos alunos cotistas e não-cotistas com coeficiente de rendimento entre 5,1 e 10,0 nos cursos de maior concorrência nos dois semestres de 2005 - UFBA 279

\begin{tabular}{|c|c|c|}
\hline Curso & Cotistas & Não-cotistas \\
\hline Administração & 83,3 & 95,4 \\
\hline Arquitetura & 85,6 & 81,3 \\
\hline Ciências da Computação & 66,6 & 53,7 \\
\hline Comunicação-Jornalismo & 100,0 & 87,5 \\
\hline Comunicação-Produção Cultural & 100,0 & 88,9 \\
\hline Direito & 95,2 & 88,9 \\
\hline Enfermagem & 87,5 & 64,2 \\
\hline Engenharia Elétrica & 55,5 & 75,0 \\
\hline Engenharia Mecânica & 75,0 & 100,0 \\
\hline Engenharia Civil & 94,1 & 80,0 \\
\hline Farmácia & 92,3 & 82,3 \\
\hline Fonoaudiologia & 100,0 & 88,9 \\
\hline Medicina & 93,3 & 84,6 \\
\hline Medicina Veterinária & 77,0 & 81,0 \\
\hline Nutrição & 87,5 & 92,3 \\
\hline Oceanografia & 27,2 & 40,0 \\
\hline Odontologia & 100,0 & 100,0 \\
\hline Psicologia & 77,8 & 100,0 \\
\hline
\end{tabular}

Novamente os dados mostram bom desempenho dos alunos cotistas, estes últimos chegando a ultrapassar o coeficiente de rendimento dos alunos não-cotistas em cursos como Medicina (93,3 para os cotistas e 84,6 para os não-cotistas) e Direito (95,2 para cotistas e 88,9 para não-cotistas).

${ }^{279}$ QUEIROZ, Delcele MascarenhasSANTOS, Jocélio Teles dos. Sistema de cotas: um debate. Dos dados à manutenção de privilégios e de poder. Educ. Soc. [online]. 2006, vol. 27, no. 962008-11-05], pp. 717-737. Disponível em $\quad \underline{h t t p: / / w w w . s c i e l o . b r / s c i e l o . p h p ? s c r i p t=s c i ~ a r t t e x t \& p i d=S 0101-~}$

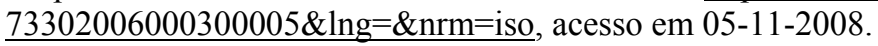




\section{As cotas racializam o país, criando o ódio racial}

Vários alertas pelos contrários às cotas foram feitos contra a classificação racial, ou a divisão do país em raças, pois essa divisão poderia criar o racismo. O manifesto "113 cidadãos anti-racistas contra as leis raciais", contrário às cotas diz: "O horizonte da trajetória de racialização promovida pelo Estado é o estabelecimento de um carimbo racial compulsório nos documentos de identidade de todos os brasileiros. A história está repleta de barbaridades inomináveis cometidas sobre a base de carimbos raciais oficialmente impostos." E completam dizendo que “A crença na raça é o artigo de fé do racismo. A fabricação de raças oficiais e a distribuição seletiva de privilégios segundo rótulos de raça inoculam na circulação sangüinea da sociedade o veneno do racismo, com seu cortejo de rancores de ódios."

O "Manifesto em defesa da justiça e constitucionalidade das cotas”, favorável às cotas, respondeu à esse argumento: "Aqui, querem nos enganar como se esse veneno ainda não existisse na sociedade brasileira e que somente agora está sendo introduzido pelo sistema de cotas. Em que evidências recentes brasileiras se baseiam para defender uma perspectiva de convivência inter-racial tão negativa? Quem está cheio de rancores e ódios? Os cotistas? Não temos notícias disso. Seus colegas brancos? Até agora a convivência inter-racial nas universidades com cotas tem sido relativamente tranqüila."

Conforme Duarte \& Guelfi:

Não há registro de qualquer atuação burocrática que vise demarcar e humilhar os alunos beneficiados pelos programas. Inexiste uma perseguição institucionalizada ao aluno cotista, mas apenas a presença das práticas discriminatórias que são já tradicionais na sociedade e nas universidades brasileiras. Ao contrário, nas instituições onde as cotas foram criadas tem-se um aumento de atividades de esclarecimento contra as práticas discriminatórias. ${ }^{280}$

280 DUARTE, Evandro C. Piza \& GUELFI, Warniley Pedroso. “Cotas raciais, política identitária e reivindicação de direitos” In: DUARTE, Evandro C. Piza, BERTÚLIO, Dora Lúcia de Lima e SILVA, Paulo Vinícius Baptista da (coords.). Cotas raciais no ensino superior. Curitiba: Juruá Editora, 2008, p. 150. 
Quanto à classificação das pessoas em raças, parece absurdo dizer que os negros, na sua interação na sociedade, não percebem o tratamento que recebem e o lugar que ocupam na sociedade. A classificação das pessoas em raças não cria o racismo, discriminação e desigualdade raciais porque elas já existem. Por outro lado, a consciência de grupo oprimido é necessária para a reivindicação de direitos. Conforme Duarte \& Guelfi:

Não apenas os negros brasileiros têm sua história marcada pela diáspora e pela colonização, como reescrevem a sua trajetória conforme seus desejos e as limitações que lhes são impostas. A ação política organizada é um meio adequado e legítimo de fazê-lo numa sociedade que pretende ser pluralista e democrática. ${ }^{281}$

Duarte \& Guelfi argumentam que as acusações contra os programas de inclusão remete ao que Galbraith chamou de "cultura do contentamento":

\begin{abstract}
"Ou seja, no decorrer da história, justamente nos momentos em que a crise de integração ameaça as instituições sociais, os beneficiados pela exclusão tendem a construir discursos que retratam a realidade em crise como "paraísos' bem ordenados.",282
\end{abstract}

Haveria uma "cegueira" para a raça, porém, "se uma sociedade olha para a aparência quando lhe convém, ela não é cega"283. Conforme Duarte \& Guelfi:

A estratégia mais simples de garantir a cegueira pode ser a de silenciar o segundo, sem intentar outro modo de sensibilização dos sentidos, permitindo que o primeiro grupo viva num eterno estado de inocência indiferente, sem alteração das condições fáticas. (...) Aquele que rompe o silêncio confortável transforma o sonho em pesadelo, ou seja, por trazer à consciência a situação dada, torna-se alvo preferencial das descargas emocionais negativas de uma situação de conflito latente. ${ }^{284}$

O fato é que, negar a existência das raças, no seu sentido social, é negar os problemas do racismo e das desigualdades raciais, o que é cômodo para os que se beneficiam com a exclusão dos negros nos melhores postos sociais e de trabalho.

\title{
6. As cotas humilham os negros
}

\footnotetext{
${ }^{281}$ Idem, p. 151.

${ }^{282}$ GALBRAITH, Jonh Kenneth. A cultura do contentamento. Apud op.cit., p. 152.

${ }^{283}$ DUARTE, Evandro C. Piza \& GUELFI, Warniley Pedroso. Op. cit. p. 152.

${ }^{284}$ Ibdem, p. 152-153.
} 
Os adversários das cotas argumentam que as cotas humilham os negros, pois haveria dúvidas quanto à sua capacidade, já que a vaga adquirida adviria de uma vantagem e não do mérito na competição. Argumenta-se também que essa política poderia afetar o orgulho da população negra.

Infelizmente, o preconceito existe. Holanda, na sua dissertação de mestrado "Trajetórias de vida de jovens negras da UnB no contexto das ações afirmativas" relata seis entrevistas com alunas negras cotistas da UnB, três alunas do curso de Direito e três alunas do curso de Pedagogia. Uma das alunas de Pedagogia citou um exemplo de preconceito que sofreu na UnB:

\begin{abstract}
Aqui? é engraçado porque assim, quando eu entrei eu pensei assim(.) ah as pessoas estão na universidade, né? a universidade abre a mente da gente, não é possível que existam pessoas preconceituosas aqui dentro(.) na semana passada eu apresentei um trabalho, um seminário sobre multiculturalismo, aí teve um mulher que levantou a mão assim, levantou a mão, ela faz Letras, ela falou assim o sistema de cotas é um absurdo, porque antes a universidade tinha um nível acadêmico, agora nós temos alunos que escrevem casa com z, isso é o que aconteceu quando entraram os cotistas(.) na hora sabe, eu falei nossa senhora aí eu falei pra ela, aí eu, eu, eu olhei para ela e falei então você acha que o nível acadêmico decaiu por que entraram negros na universidade? aí eu falei pra ela então isso quer dizer que os negros não são capazes, né? aí ela eu não tô falando que são incapazes, mas eles não são inteligentes(.) ah é eu não sei o quê é que eu faço né? aí a professora interveio e falou e deu assim algumas respostas assim a ela(.) mas tipo, o que eu falei, o que a professora falou, eu sei que assim, tipo, não fizeram a menor diferença pra ela(.) ela saiu dali achando aquilo sabe com a mesma idéia(.) e por mais que a gente falasse, que a gente tentasse convencê-la do contrário, sabe, tipo, ela diz que né? os cotistas são inadequados pra universidade, aí eu pensei: bom quem será adequado né? quem pode dizer isso? quem foi que estabeleceu esse padrão de adequação? eu fiquei assim meio indignada. ${ }^{285}$
\end{abstract}

Sabemos, no entanto, que o preconceito existe independentemente das cotas. Os relatos das alunas da UnB, no estudo de Holanda, falam de eventos anteriores onde sofreram preconceito e não eram ainda alunas cotistas. Na verdade, a conquista do direito às cotas raciais é um motivo de orgulho para a população negra, pois resulta de um passado de lutas. Além disso, os alunos cotistas têm a mesma formação que os alunos não-cotistas, passam pelos mesmos cursos e mesmas avaliações, logo, não há porque discriminá-los pela formação. De qualquer maneira, estarão mais preparados para o mercado de trabalho. Conforme Munanga:

285 HOLANDA, Maria Auxiliadora de Paula Gonçalves. "Trajetórias de vida de jovens negras da UnB no contexto das ações afirmativas". Dissertação de mestrado, Faculdade de Educação, Universidade de Brasília, 2008, p. 140 
Mas uma coisa é certa, os negros que ingressarão nas universidades públicas de boa qualidade pelas cotas terão, talvez, uma oportunidade única na sua vida: receber e acumular um conhecimento científico que os acompanhará no seu caminho da luta pela sobrevivência. Apesar dos preconceitos que persistirão ainda por muito tempo, eles serão capazes de se defender melhor no momento das grandes concorrências e nos concursos públicos e exibir um certo conhecimento que não dominavam antes. Abrirão com facilidade algumas portas, graças a esse conhecimento adquirido e ao restabelecimento de sua auto-estima. ${ }^{286}$

Ademais, o que humilha os negros não são as ações afirmativas, mas o racismo. Vejamos trecho da notícia que cita o depoimento de uma aluna de Direito da UERJ, 22 anos, que entrou em 2004 por cota racial:

Allyne Andrade Silva, 22, aluna de direito que entrou em 2004 por cota racial, diz que se sentiu discriminada não por ser cotista, mas por ser negra. 'Quando procurei estágio, por exemplo, nunca me perguntaram se eu era cotista ou não, mas tenho certeza de que, em alguns locais, me barraram por ser negra. ${ }^{287}$

Outro depoimento, de Mariana Ferreira, também aluna de Direito da UERJ da primeira turma de cotistas, relata:

O diploma de Direito da UERJ abre muitas portas, mas mulher negra, de cabelo trançado como eu não consegue estágio fácil em escritório. Só consegui em setor público. ${ }^{288}$

\footnotetext{
${ }^{286}$ MUNANGA, Kabengele. Políticas de ação afirmativa em benefício da população negra no Brasil - Um ponto de vista em defesa de cotas. (consulta na internet, endereço espacoacadêmico.com.br/o22/22cmunanga.htm, acesso em 13/11/2007).

287 JORNAL "FOLHA DE SÃO PAULO", 08-01-2008, Caderno Cotidiano, p. 5.

${ }^{288}$ JORNAL “O ESTADO DE SÃO PAULO”, 09-11-2008, p. A26.
} 


\subsection{Argumentos a favor das cotas conforme José Jorge de Carvalho e conforme divulgado pela Universidade de Brasília - UnB}

José Jorge de Carvalho sintetiza em quatro as motivações para justificar a legitimidade das cotas nas universidades.

O primeiro argumento seria o da reparação: a comunidade negra exige uma compensação pela tragédia da escravidão. As cotas para afro-descendentes é uma das tantas formas de reparação. O segundo argumento seria a cobrança de um direito. A Constituição de 1988 assegurava um tratamento igual a todos cidadãos, no entanto, a desigualdade é "escandalosa", ou seja, a comunidade negra encontra-se sub-representada no ensino superior. O terceiro argumento diz que a presença de negros e índios enriquecerá a produção de saberes e revisará o eurocentrismo presente nas universidades. $\mathrm{O}$ quarto argumento diz que propor cotas é abrir a discussão sobre a sociedade racista em que vivemos, forçar uma tomada de posição para reverter esse quadro e construir um ambiente universitário livre de práticas racistas e discriminatórias. ${ }^{289}$

A Universidade de Brasília posicionou-se da seguinte maneira quanto às razões de implementação do sistema de cotas para a população negra:

“As políticas públicas de ação afirmativa direcionadas à população negra têm como objetivo o enfrentamento de um quadro de desigualdades raciais, reconhecido até mesmo pelo Estado brasileiro. Nesse sentido, a implantação do Sistema de Cotas para Negros acarreta uma série de impactos sociais, por exemplo:

- Instauração, no espaço acadêmico, de um mecanismo reparador das perdas infringidas à população negra brasileira;

- Acusar a existência do racismo e combatê-lo de forma ativa;

- Redirecionamento do futuro da sociedade, rumo a uma nova história;

- Garantia do acesso emergencial da população negra à educação superior;

${ }^{289}$ CARVALHO, José Jorge de. Inclusão étnica e racial no Brasil. São Paulo: Attar Editorial: 2005, p. 115. 
- Possibilidade de avaliação das conseqüencias da inclusão de Negros e Negras na vida universitária;

- Capacidade de auto-correção, podendo ser periodicamente verificado e melhorado;

- Aprimoramento da capacidade de aprendizagem da comunidade acadêmica;

- Convivencia plural e diária com a diversidade humana em sua variedade de experiências e perspectivas;

- Treino dos universitários para a sociabilidade, adaptação e tolerância;

- Estímulo da confiança de crianças e adolescentes negros em sua capacidade de realização;

- Estímulo aos estudantes negros para demandar de suas escolas um melhor nível educacional;

- Desafio aos professores para melhorarem a performance de seus alunos negros;

- Conscientização sobre o que é ser Negro no Brasil;

- Reconhecimento da sociedade em geral quanto à sua capacidade de tornar mais justa a realidade;

- Associar a cor da pele negra a signos de poder, autoridade e prestígio;

- Irradiação dessas influências benéficas para todo o país." 290

\subsection{Aprovação na Câmara Federal do Projeto de lei no $73 / 1999$}

Em 20-11-2008 a Câmara Federal aprovou o projeto de lei no 73/1999, que seguirá para o Senado Federal, para apreciação. Segundo o projeto, artigo $1^{\circ}$, as instituições federais de educação superior vinculadas ao Ministério da Educação reservarão em cada concurso seletivo para ingresso nos cursos de graduação, 50\% (cinqüenta por cento) de suas vagas para estudantes que tenham cursado integralmente o ensino médio em escolas públicas. Dessas vagas, $50 \%$ deverão ser reservadas para estudantes oriundos de famílias com renda igual ou inferior a 1,5 salário mínimo per capita.

${ }^{290}$ Consulta na internet, endereço http://www.unb.br/admissao/sistema_cotas/index.php, acesso em 10-11-2008 
$\mathrm{O}$ artigo $3^{\circ}$ do projeto dita que as vagas de que trata o artigo $1^{\circ}$ serão preenchidas por autodeclarados negros, pardos e indígenas, no mínimo igual à proporção de negros, pardos e indígenas na população da unidade da Federação onde está instalada a instituição, segundo o último censo da Fundação Instituto Brasileiro de Geografia e Estatística - IBGE.

Regras semelhantes foram feitas para instituições federais de ensino técnico de nível médio. $\mathrm{O}$ artigo $4^{\circ}$ reserva $50 \%$ no mínimo das vagas para estudantes que cursaram integralmente o ensino fundamental em escolas públicas. Dessas vagas, $50 \%$ deverão ser reservadas aos estudantes oriundos de famílias com renda igual ou inferior a 1,5 salário mínimo per capita.

Conforme artigo $5^{\circ}$, as vagas de que trata o artigo $4^{\circ}$ serão preenchidas por autodeclarados negros, pardos e indígenas, no mínimo igual à proporção de negros, pardos e indígenas na população da unidade da Federação onde está instalada a instituição, segundo o último censo do IBGE.

No projeto, note-se a inserção de reserva de vagas para estudantes oriundos de famílias com renda igual ou inferior a 1,5 salário mínimo per capita, além de serem egressos do ensino médio público. Esse limite máximo de renda caracteriza a clara intenção do legislador de inserir estudantes com baixo poder aquisitivo. Esse critério de renda máxima para os cotistas pode ser notado na UERJ (Universidade Estadual do Rio de Janeiro) e UENF (Universidade Estadual do Norte Fluminense), onde, para concorrer ao sistema de cotas, o candidato deverá ter renda per capita mensal bruta igual ou inferior a $\mathrm{R} \$ 960,00$. 


\section{Fundamentos da justiça social}

\subsection{Antecedentes históricos da justiça social}

Para o estudo da Justiça e sua tipologia, é grande a influência dos filósofos gregos Platão e Aristóteles e do teólogo cristão São Tomás de Aquino. Platão em A República inicia o diálogo buscando a idéia de justiça. Primeiro rejeita a definição de Simonides segundo a qual a justiça consiste em dar a cada um o que lhe é devido. Nesse sentido, justiça seria fazer bem aos amigos e mal aos inimigos. Porém, julgamos quem é amigo ou inimigo pelas aparências, e as aparências enganam. E não é propriedade do bom, mas do seu oposto, danificar, logo, em caso algum é da justiça prejudicar a quem quer que seja. ${ }^{291}$ Nesse contexto, conforme Comparato:

Para Platão em hipótese alguma o homem justo pode prejudicar os outros, sejam eles seus amigos ou inimigos. Por esse raciocínio, Platão chega a uma primeira definição da essência da justiça: não devemos fazer aos outros o que não queremos que eles nos façam. ${ }^{292}$

Platão distinguia dois tipos de justiça: uma absoluta e outra relativa. "A absoluta, ou divina, é a justiça perfeita. É aquela que se apresenta reservada às almas para após a morte, ao além. Tem o caráter de retribuição: pagar o mal com o mal e recompensar o bem com o bem. A segunda modalidade é aquela justiça humana e palpável. (...) Platão situa a justiça humana como uma virtude indispensável à vida em comunidade. É ela que propicia a convivência harmônica e cooperativa entre os seres humanos em coletividade." 293

Para a comunidade Platão formula um Estado Ideal. Este Estado seria composto por três classes, a saber: a primeira, a dos agricultores, comerciantes e industriais, incubida de promover o sustento econômico; a segunda, a dos militares; a terceira, a dos governantes e filósofos. A divisão do trabalho ocorreria de acordo com a aptidão de cada um, aproveitando o

\footnotetext{
${ }^{291}$ PLATÃO. A República. Bauru, SP: Edipro, 1994, p. 9-23

${ }^{292}$ COMPARATO, Fábio Konder. Ética. São Paulo: Companhia das Letras, 2006, p. 525.

293 JUNKES, Sérgio Luiz. Defensoria Pública e o Princípio da Justiça Social. Curitiba: Juruá, 2006, p. 23.
} 
talento e capacidade de cada um. A justiça, no contexto dessa República "consiste em que cumpra cada um com seu dever, faça o que tem de fazer" ${ }^{294}$.

Para Junkes:

Em suma, e em outros termos, a par do auto-interesse de cada pessoa em suprir as suas próprias carências e obter autonomia, assenta-se também a teoria platônica de justiça em um verdadeiro interesse comum distributivo. Deve ele possibilitar a melhoria uniforme da existência de todos. A ordem na cidade representa a justiça, e a desordem, a injustiça. ${ }^{295}$

Aristóteles distingue a justiça em universal e particular. A justiça universal corresponde às leis da comunidade, sempre objetivando o bem público. A justiça particular é aquela onde o padrão do que é devido é dado pela noção de igualdade. Classifica-se em justiça distributiva (ou geométrica) e justiça corretiva (ou aritmética):

Um tipo é exercido na distribuição de honra, riqueza e os demais ativos divisíveis da comunidade, os quais podem ser atribuídos entre seus membros em porções iguais ou desiguais. (justiça distributiva) $\mathrm{O}$ outro tipo é aquele que supre um princípio corretivo nas relações privadas. (justiça corretiva) ${ }^{296}$

\section{Referindo-se à justiça distributiva:}

E haverá a mesma igualdade entre as porções tal como entre os indivíduos, uma vez que a proporção entre as porções será igual à proporção entre os indivíduos, pois não sendo pessoas iguais, não terão porções iguais - é quando os iguais detêm ou recebem porções desiguais, ou indivíduos desiguais detêm ou recebem porções iguais que surgem conflitos e queixas. ${ }^{297}$

\section{Sobre a justiça corretiva Aristóteles nos fala:}

(...) a lei apenas considera a natureza do dano, tratando as partes como iguais, limitando-se a indagar se alguém praticou injustiça enquanto o outro a sofreu e se alguém praticou o dano e se o outro foi atingido. Consequentemente, sendo o injusto aqui o desigual, o juiz se empenha em tornálo igual... ${ }^{298}$

\footnotetext{
${ }^{294}$ PLATÃO. Op. cit. p. 154

${ }^{295}$ JUNKES. Op. cit. p. 24

${ }^{296}$ ARISTÓTELES. Ética a Nicômaco. São Paulo: Edipro, 2002, livro V, p. 140

${ }^{297}$ idem, p. 141

298 idem, p. 143.
} 
Notamos que a justiça distributiva visa estabelecer igualdade onde há desigualdade e a justiça corretiva visa restabelecer a igualdade onde ela foi rompida.

São Tomás de Aquino define "a justiça é um hábito pelo qual, com vontade constante e perpétua, atribuímos a cada um o que lhe pertence" ${ }^{299}$. Ou seja, a definição é praticamente a de Simonides. Para São Tomás a justiça implicando a igualdade ordena o homem nas suas relações com o outro, "pois nada é igual a si mesmo, mas a outrem" ${ }^{300}$. Essa relação pode ser com outro singularmente considerado ou com outro em geral, no sentido em que quem serve a uma comunidade serve a todos os indivíduos nela contidos.

E como o próprio da lei é ordenar o homem para o bem comum, como já estabelecemos, daí resulta que essa justiça geral, ao modo que referimos, chama-se justiça legal, porque, obedecendo-lhe, o homem procede de acordo com a lei, ordenadora de todos os atos para o bem comum. ${ }^{301}$

A relação com o outro singularmente considerado chama-se justiça particular. A justiça particular pode ser de dois tipos: justiça comutativa e justiça distributiva.

Ora, as partes são suscetíveis de dupla relação. Uma, entre si, a que se assemelham as relações das pessoas particulares entre si. E, esta relação é dirigida pela justiça comutativa, que regula os atos entre duas pessoas particulares. Outra é a relação entre o todo e as partes, à qual é comparável a relação entre o comum e o particular. E essas relações as dirige a justiça distributiva, que distribui os bens proporcionalmente. ${ }^{302}$

Notamos pelos trechos citados que São Tomás segue a classificação aristotélica, denominando a justiça universal de justiça legal e a justiça corretiva de justiça comutativa. Mantém a denominação justiça distributiva.

${ }^{299}$ AQUINO, São Tomás de. Suma teológica. 2a parte da $2^{\mathrm{a}}$ parte. Porto Alegre: Escola Superior de Teologia São Lourenço de Brindes e Livraria Sulina, 1980, p. 2487

${ }^{300}$ Idem, p. 2488.

${ }^{301}$ Idem, p. 2492

${ }^{302}$ Idem, p. 2515. 


\subsection{Conceitos de Justiça Social}

A expressão justiça social parece ter sido utilizada pela primeira vez ${ }^{303}$ por Luigi Taparelli-d'Azeglio, em “Saggio teoretico di diritto naturalle” (Palermo, 1849):

Capítulo III Noções de Direito e da Justiça Social.

353. Da idéia do Direito nasce espontaneamente a idéia de justiça social. Uma consciência virtuosa admira a ordem e a ama em si mesmo e nos outros, e consequentemente inclina-se (tem a tendência) a preservá-la de forma que ao direito corresponda exatamente o cumprimento do dever. A essa tendência habitual a igualar as partes denomina-se justiça, mas para estabelecer essa igualdade a justiça deve ter bases sobre as quais faz seus juízos: quais serão essas bases?

354. A justiça social é para nós justiça entre o homem e o homem (pessoa e pessoa).Quais serão as proporções entre pessoa e pessoa? Basta considerar a forma da pergunta para entender que estou falando aqui do homem em abstrato, do homem que é considerado dotado dos requisitos normais da humanidade, definido como simples animal racional. Entre o homem e homem considerado sob este aspecto é claro que ele está presumindo relações de perfeita igualdade, porque homem e outro homem aqui não significa senão a humanidade reproduzida duas vezes: Pode então haver igualdade de proporções maior que esta? Posso, portanto, concluir que a justiça social deve igualar de fato todas as pessoas naquilo que se espera referente aos direitos de humanidade (direitos humanos?), assim como o Criador os igualou na natureza; e que o homem operando e adotando a norma de tal justiça cumpre as intenções de quem o criou.

355. Mas calma: Onde está este homem abstrato, essa humanidade replicada cuja noção eu sugeri nas primeiras linhas de justiça social? Se existem homens associados a outros homens, existem sempre de maneira concreta, sempre como indivíduos, sempre dotados de força, de qualidades bem determinadas. Mas quando eu considero os homens sob este novo aspecto, onde está a igualdade? Compare idade com idade, talento com talento, força com força, etc.., tudo o que é disparidade entre os homens e as diferenças, notem, derivam da natureza, já que a natureza é a que forma os indivíduos, assim como ela forma as espécies, melhor dizendo, a natureza forma os indivíduos e o homem classifica e ordena as espécies. Concluirei portanto que todos os seres humanos são naturalmente desiguais em relação à sua individualidade, assim como são naturalmente iguais em relação à sua espécie; e então a obra do homem será justa quando for apropriada aos direitos individuais, diferentes daqueles tratados no capítulo XLVI (sobre a igualdade natural). ${ }^{304}$ (tradução livre)

\footnotetext{
${ }^{303}$ HAYEK, Friedrich A. von, A miragem da justiça social. In: MAFFETONE, Sebastião \& VECA, Salvatore (orgs). A idéia de justiça de Platão a Rawls. São Paulo: Martins Fontes, 2005, p.373.

${ }^{304}$ TAPARELLI-D’AZEGLIO, Luigi. Saggio Teoretico di diritto naturalle. Appogiato Sul Fatto. Sesta

Edizione volume primo, Palermo, 1857, p.109.

O texto original corresponde ao seguinte:
} 
Ou seja, Taparelli chama de justiça social a justiça entre o homem e o homem, no sentido da sua humanidade, naquilo que são iguais, ou seja, seres da mesma espécie, da mesma natureza, animais racionais: "está presumindo relações de perfeita igualdade, porque homem e outro homem aqui não significa senão a humanidade reproduzida duas vezes".

Avancemos aos conceitos atuais de justiça social. Vejamos o conceito de justiça social para Barry:

A justiça social é um atributo das instituições sociais que, no conjunto, determinam o acesso - ou as possibilidades de acesso - dos membros de uma sociedade a recursos que são meios para a safisfação de uma grande variedade de desejos. ${ }^{305}$

Vejamos o conceito de justiça social para Junkes:

justiça social é a resultante de uma Sociedade estruturada de forma a garantir e promover, contínua e simultaneamente: (a) a igualdade de todos os seus integrantes no que se refere à liberdade, dignidade e oportunidades; (b) a redução dos desequilíbrios sociais. Por desequilíbrios sociais querse referir às desigualdades econômicas, sociais e culturais existentes entre os membros de determinada Sociedade. ${ }^{306}$

CAPO III NOZIONI DEL DIRITTO E DELLA GIUSTIZIA SOCIALE

353.Dalla idea del dritto nasce spontanea la idea di giustizia sociale. Un animo retto ammira l'ordine e lo ama in se e negli altri, e per conseguenza inchina a custodirlo, facendo si che AL dritto corrisponda esattamente l'adempimento Del dovere. Questa abitual inclinazione a ragguagliare Le partite suol dirsi giustizia: ma per istabilire questo ragguaglio Ella dee aver delle basi sopra cui formare i suoi giudizii: quali sarano queste basi?

354. La giustizia sociale è per noi giustizia fra uomo e uomo. Or quali proporzioni passano fra uomo e uomo? Basta considerare La forma Del quesito per comprendere Che io parlo qui Dell' uomo in astratto, Dell' uomo cioè considerato come dotato dei soli requisiti di umanità, considerato come puro animal ragionevole. Fra uomo e uomo considerato sotto tale aspetto egli è claro que passano relazioni di perfettissima uguaglianza, perocchè uomo e uomo altro qui non significa se non La umanità replicata due volte: si può dare maggiore uguaglianza di proporzioni? Posso dunque conchiudere Che La giustizia sociale debbe ragguagliare nel fatto tutti gli uomini in ciò Che spetta i dritti di umanità, siccome Il Creatore li ragguagliò nella natura; e Che l'uomo operando a norma di tal giustizia compie gli intenti di chi lo creò.

355. Ma adagio: dove è questo uomo astratto, questa umanità replicata La cui nozione mi há suggerito i primi lineamenti della giustizia sociale? Se esistono uomini associati ad altri uomini, esistono sempre in concreto, sempre individuali, dempre dotati di forze di propietà determinate. Or quando io considero gli uomini sotto questo nuovo aspetto dove è La uguaglianza? Paragonate età com età, ingegno com ingegno, robustezza com robustezza, eccetera, tuttoè qui disparità fra gli uomini; e disparità, notatelo, Che deriva dalla natura, giacchè La natura è quella que forma gl’ individui come Ella forma Le spezie; anzi diciamo meglio, La natura forma gli individui, l'uomo ravvisa Le specie. Concluderó dunque rettamente Che tutti gl'individui umani sono fra loro naturalmente disuguali per ciò Che s`aspetta alla individualità, come sono uguali naturalmente per ciò Che se aspetta Allá specie; e però l’ operar Dell 'uomo allora sarà giusto quando sarà appropriato ai dritti individuali diversi di quelli con cui tratta nel capitolo XLVI.(sopra La uguaglianza naturale).

${ }^{305}$ BARRY, Brian, apud FIGUEIREDO, Argelina Cheibub. "Princípios de justiça e avaliação de políticas". Lua Nova - revista de cultura e política, ${ }^{\circ}$ 39, p. 73-74, 1997.

${ }^{306}$ JUNKES, Sérgio Luiz. Defensoria Pública e o Princípio da Justiça Social. Curitiba: Juruá, 2006, p. 47. 
Passemos às considerações de Samuel Fleischacker. Notemos que o autor utiliza a expressão "justiça distributiva" como sinônima das expressões "justiça social" e "justiça econômica" ${ }^{307}$.

\section{Segundo Fleischacker:}

Até muito recentemente, as pessoas não reconheciam que a estrutura básica da distribuição de recursos em suas sociedades era uma questão de justiça, e tampouco consideravam que a justiça deveria exigir uma distribuição de recursos que satisfizesse as necessidades de todos. É para esse último objeto que está voltada a justiça distributiva em seu sentido atual, e nesse sentido específico a noção tem pouco mais de dois séculos de existência. ${ }^{308}$

O sentido moderno de justiça distributiva (justiça social) difere do sentido antigo ou medieval. A justiça distributiva segundo Aristóteles referia-se à distribuição de bens às pessoas segundo seus méritos, sobretudo os bens políticos e São Tomás de Aquino quando recupera a concepção de justiça distributiva de Aristóteles praticamente a mantém intacta.

Aristóteles jamais colocou o problema de como distribuir recursos escassos sob o título de justiça distributiva, nem considerou que a necessidade pudesse ser o fundamento de qualquer reivindicação de propriedade. ${ }^{309}$

Para Fleischacker, algumas premissas são necessárias para se chegar ao conceito moderno de justiça distributiva:

1. Cada indivíduo, e não somente sociedades ou a espécie humana como um todo, tem um bem que merece respeito, e aos indivíduos são devidos certos direitos e proteções com vistas à busca daquele bem;

2. Alguma parcela de bens materiais faz parte do que é devido a cada indivíduo, parte dos direitos e proteções que todos merecem;

3. O fato de que cada indivíduo mereça isso pode ser justificado racionalmente, em termos puramente seculares;

4. A distribuição dessa parcela de bens é praticável: tentar conscientemente realizar essa tarefa não é um projeto absurdo nem é algo que, como ocorreria caso se tentasse tornar a amizade algo compulsório, solaparia o próprio objetivo que se tenta alcançar; e

5.Compete ao Estado, e não somente a indivíduos ou organizações privadas, garantir que tal distribuição seja realizada. ${ }^{310}$

\footnotetext{
${ }^{307}$ FLEISCHACKER, Samuel. Uma breve história da justiça distributiva. São Paulo: Martins Fontes, 2006, p. 3.

${ }^{308}$ Idem, p. 4.

${ }^{309}$ Idem, p. 4.

${ }^{310}$ FLEISCHACKER, Samuel. Op. Cit. p. 12
} 
Na Idade Antiga e Idade Média não existia a idéia de que as pessoas teriam direito à distribuição de bens e riqueza da sociedade. Existia a caridade como forma de ajuda aos pobres e esta dependia da boa vontade de quem fazia a caridade. A ajuda estatal aos pobres era condicionada a sua condição de impedimento para o trabalho, havendo severas punições aos que recorriam à caridade se podiam trabalhar.

Graco Babeuf foi o primeiro a falar que a justiça exige que o Estado redistribua bens aos pobres, atribuindo a todos um direito perfeito, estrito e coercitivo, a uma parcela igual em toda a riqueza, e, embora Babeuf não usasse o termo justiça distributiva, "a justiça foi tratada pela tradição do direito natural desde Grócio como correlata a reivindicações de direitos perfeitos". 311 Babeuf foi líder de uma tentativa abortada de golpe em 1796, no fim da Revolução Francesa.

Muitos distributivistas que vieram depois não compartilham das inclinações revolucionárias de Babeuf. Tampouco entoariam todos eles em coro essa exigência de igualdade estrita e de abolição da propriedade. Contudo, não são esses aspectos do babouvismo que importam para nossos propósitos. O que importa é que Babeuf converteu o não viver em pobreza em um direito político, que colocou na agenda política, pela primeira vez, um direito de todas as pessoas a um certo status socioeconômico - não porque a pobreza seja um obstáculo à capacidade de as pessoas serem boas cidadãs, mas porque a pobreza é uma afronta - na verdade, uma injúria sujeita à autoridade judiciária - 'as pessoas na condição de seres humanos. Bastante tempo ainda se passaria antes que muitos Estados viessem a fazer um esforço para implementar um tal direito, mas a noção de justiça distributiva, em sua forma moderna, finalmente chegara. ${ }^{312}$

A "politização" da pobreza começou na Grã-Bretanha na época da Revolução Francesa, devido ao exemplo da própria Revolução e a uma crise de alimentos, onde as pessoas começaram a considerar uma renda de subsistência como algo a que tinham direito.

Em 1796, William Pitt pediu que o Parlamento 'fizesse do auxílio nos casos em que há várias crianças um direito e uma honra' e redigiu um projeto de lei que, se tivesse sido aprovado, teria dado à Grã-Bretanha um conjunto de programas de seguro social muito mais abrangente do que qualquer outro país jamais tivera até então. ${ }^{313}$

\footnotetext{
${ }^{311}$ Ibdem, p. 111.

312 Ibdem, p. 115

${ }^{313}$ Ibdem, p. 119
} 
Depois da Revolução Francesa, embora com movimentos discordantes, a ideologia de que as pessoas teriam direito legal a melhores condições econômicas propagou-se rapidamente.

Por exemplo, a lei norueguesa em 1845 tornou o auxílio público um direito legal para idosos, doentes, aleijados, lunáticos e órfãos; na década seguinte a Finlândia e a Suécia estabeleciam a obrigação legal das autoridades locais de cuidarem de seus pobres; porém, essas leis duraram menos de uma geração. Foi no início do século XX, em 1900 na Noruega e 1922 na Finlândia que novas leis tornaram obrigatória a assistência a todos aqueles que não pudessem prover o próprio sustento. Na Suécia, em 1918 haviam leis semelhantes. ${ }^{314}$

A Constituição Mexicana de 1918 e a Constituição alemã de 1919 marcam a segunda geração de direitos humanos, os direitos sócio-econômicos. São direitos prestacionais, ou seja, o Estado torna-se um interventor na sociedade para a concretização desses direitos.

Na Declaração Universal dos Direitos Humanos de 1948 também encontramos direitos exigidos pela Justiça Social. O artigo 22 declara que todo homem, como membro da sociedade, tem direito à seguridade social e à realização dos direitos econômicos, sociais e culturais indispensáveis à sua dignidade e ao livre desenvolvimento de sua personalidade. $\mathrm{O}$ artigo 23 diz que todo homem tem direito à proteção contra o desemprego e o artigo 25 diz que todo homem tem direito a um padrão de vida capaz de assegurar, a si e à sua família, saúde e bem-estar, inclusive alimentação, vestuário, habitação, cuidados médicos e os serviços sociais indispensáveis, e direito à segurança em caso de desemprego, doença, invalidez, viuvez, velhice e outros casos de perda dos meios de subsistência em circunstâncias fora de seu controle.

${ }^{314}$ GEORGE, Nelson. apud FLEISCHACKER, Samuel, op. cit.. p.229 


\subsection{John Rawls}

Em 1971 é publicado "Uma teoria da Justiça”, de John Rawls. Atualmente essa obra é considerada um marco no pensamento sobre a justiça social. Para Rawls:

A justiça é a virtude primeira das instituições sociais, tal como a verdade o é para os sistemas de pensamento. Cada pessoa goza de uma inviolabilidade que decorre da justiça, a qual nem sequer em benefício do bem-estar da sociedade como um todo poderá ser eliminada. (...) Não permite [a justiça] que os sacrifícios impostos a uns poucos sejam compensados pelo aumento das vantagens usufruídas por um maior número. ${ }^{315}$

Dessa forma, a justiça é fundamental para a sociedade. Rawls define sociedade como:

uma associação de pessoas, mais ou menos auto-suficientes, as quais, nas suas relações, reconhecem certas regras de conduta como sendo vinculativas e, na sua maioria, agem de acordo com elas. ${ }^{316}$

Na sociedade há identidade de interesses e conflito de interesses.

Há identidade de interesses uma vez que a cooperação torna possível uma vida que, para todos, é melhor do que aquela que cada um teria se tivesse de viver apenas pelos seus próprios esforços. Há conflitos de interesses uma vez que os sujeitos não são indiferentes à forma como são distribuídos os benefícios (...), todos preferem receber uma parte maior dos mesmos. ${ }^{317}$

Em razão desse conflito de interesses, é necessário um conjunto de princípios que permitam uma opção entre as diversas formas de ordenação social, as quais determinam a divisão desses benefícios.

Esses princípios são os da justiça social: são eles que fornecem um critério para a atribuição de direitos e deveres nas instituições básicas da sociedade e definem a distribuição adequada dos encargos e benefícios da cooperação social. ${ }^{318}$

Há muitas coisas que podem ser consideradas justas ou injustas. Rawls nos diz que seu tema é o da justiça social, e o objeto primário da justiça é a estrutura básica da sociedade, a qual define como:

\footnotetext{
${ }^{315}$ RAWLS, John. Uma teoria da justiça. Lisboa, Presença, 1993, p.27

${ }^{316}$ idem, p. 28

${ }^{317}$ idem, p. 28

${ }^{318}$ idem, p. 28
} 
a forma pela qual as instituições sociais mais importantes distribuem os direitos e deveres fundamentais e determinam a divisão dos benefícios da cooperação em sociedade. Por instituições mais importantes entendo a constituição política, bem como as principais estruturas econômicas e sociais. $^{319}$

\section{Os princípios de justiça}

Rawls vai estabelecer seus princípios de justiça baseando-se num contrato hipotético entre os membros da sociedade. Diferentemente de Locke, Rousseau e Kant, o contrato original não se refere à adesão a determinada sociedade ou forma de governo.

A idéia condutora é antes a de que os princípios da justiça aplicáveis à estrutura básica formam o objeto do acordo original. Esses princípios são os que seriam aceites por pessoas livres e racionais, colocadas numa situação inicial de igualdade e interessadas em prosseguir os seus próprios objetivos, para definir os termos fundamentais da sua associação. ${ }^{320}$

A situação inicial de igualdade na qual os sujeitos se encontram é denominada posição original. Na posição original:

ninguém conhece a sua posição na sociedade, a sua situação de classe ou o estatuto social, bem como a parte que lhe cabe na distribuição dos atributos e talentos naturais, como a sua inteligência, a sua força e mais qualidades semelhantes. Parto inclusive do princípio de que as partes desconhecem as suas concepções do bem ou as suas tendências psicológicas particulares. Os princípios da justiça são escolhidos a coberto de um véu da ignorância. ${ }^{321}$

O véu da ignorância impede que as pessoas conheçam sua posição na sociedade, sua família, riqueza, dotes naturais, como os talentos, a saúde, e a pessoa desconhece sua concepção do bem. Com isso, busca-se evitar que o indivíduo faça escolhas em função das suas diferenças ou desigualdades, como ele não tem essas informações, precisa levar em conta, ao tomar suas decisões sobre quais deveriam ser os princípios de justiça, que ele tanto pode ser nessa sociedade um agente afortunado como desafortunado pelas circunstâncias e sorte.

\footnotetext{
${ }^{319}$ idem, p.30

${ }^{320}$ ibdem, p. 33

${ }^{321}$ ibdem, p.33-34
} 
A posição original, baseada no véu da ignorância, representa uma situação eqüitativa entre os participantes da sociedade. ${ }^{322}$

As partes, na posição original, correspondem a seres racionais e mutuamente desinteressados. São racionais pois escolhem a via mais efetiva para atingir fins determinados e são desinteressadas pois são concebidas como não estando interessadas nos interesses dos outros. $^{323}$

Dada a posição original, os membros da sociedade vão estabelecer seus princípios de justiça. Esses princípios possuem uma prioridade serial ou lexical, ou seja, "exige que se satisfaça o primeiro princípio representado antes de se passar para o segundo, o segundo antes de se analisar o terceiro., 324

Isso significa que, sendo os princípios ordenados, para se aplicar o segundo princípio, é necessário que o primeiro princípio seja satisfeito, para se aplicar o terceiro princípio, é necessário que o segundo seja satisfeito.. Com a prioridade lexical, Rawls resolve o problema da prioridade, não solucionado no intuicionismo, ou seja, dada uma situação, sabemos qual ordem de princípios devemos seguir.

Examinemos os dois princípios de justiça de Rawls numa formulação mais recente:

a. Toda pessoa tem um direito igual a um sistema plenamente adequado de liberdades fundamentais iguais, que seja compatível com um sistema similar de liberdade para todos.

b. as desigualdades sociais e econômicas devem satisfazer duas condições. A primeira é que devem estar vinculadas a cargos e posições abertos a todos em condições de igualdade eqüitativa de oportunidades; e a segunda, é que devem redundar no maior benefício possível para os membros menos privilegiados da sociedade. ${ }^{325}$

Quanto às liberdades fundamentais iguais, Rawls faz uma lista: a liberdade de pensamento e consciência; as liberdades políticas e a liberdade de associação, assim como as liberdades especificadas pela liberdade e integridade da pessoa; e finalmente, os direitos e

\footnotetext{
${ }^{322}$ ibdem, p.34

323 ibdem, p. 35

324 ibdem, p. 55

${ }^{325}$ RAWLS, John. O liberalismo político. São Paulo: Ática, 2000, p. 345.
} 
liberdades abarcados pelo império da lei. Entre as liberdades fundamentais, não há prioridade especial para qualquer liberdade específica. ${ }^{326}$

O segundo princípio refere-se à possibilidade de haver desigualdades, as quais devem obedecer a duas condições: primeira, que os cargos e posições estejam abertos a todos com igualdade eqüitativa de oportunidades; segunda, que as desigualdades só se justificam se melhorar a situação dos menos favorecidos da sociedade. Essa segunda condição é conhecida como princípio da diferença.

Do que foi exposto, notamos forte relação entre a justiça social e a igualdade. A justiça social propõe-se a diminuir desigualdades ou buscar mais igualdade. Os conceitos não se confundem pois conforme teóricos como Rawls, é possível haver uma sociedade justa com alguma desigualdade, desde que esta satisfaça às condições enunciadas.

Quanto às desigualdades relacionadas ao princípio de diferença Rawls explica:

Dizer que as desigualdades de renda e riqueza têm de ser dispostas de modo que elevem ao máximo os benefícios para os menos favorecidos significa simplesmente que temos de comparar esquemas de cooperação e verificar a situação dos menos favorecidos em cada esquema, e em seguida escolher o esquema no qual os menos favorecidos estão em melhor situação do que em qualquer outro. $^{327}$

Para definir quem são os menos favorecidos, Rawls introduz a idéia de bens primários:

Estes consistem em diferentes condições sociais e meios polivalentes geralmente necessários para que os cidadãos possam desenvolver-se adequadamente e exercer plenamente suas duas faculdades morais $^{328}$, além de procurar realizar suas concepções do bem. ${ }^{329}$

Rawls distingue cinco tipos de bens primários:

\footnotetext{
${ }^{326}$ Idem, p. 345

${ }^{327}$ RAWLS, John. Justiça como eqüidade - Uma reformulação. São Paulo: Martins Fontes, 2003, p. 83-84.

${ }^{328}$ Rawls refere-se a duas faculdades morais de pessoas livres e iguais, envolvidas na cooperação social: "Uma dessas faculdades é a capacidade de ter um senso de justiça: é a capacidade de compreender e aplicar os princípios de justiça política que determinam os termos eqüitativos de cooperação social, e de agir a partir deles (e não apenas de acordo com eles). A outra faculdade moral é a capacidade de formar uma concepção do bem: é a capacidade de ter, revisar e buscar atingir de modo racional uma concepção do bem." RAWLS, John. Justiça como eqüidade - Uma reformulação. São Paulo: Martins Fontes, 2003 p. 26.

${ }^{329}$ Idem, p. 81
} 
(I) Os direitos e liberdades básicos: as liberdades de pensamento e de consciência, e todas as demais. Esses direitos e liberdades são condições institucionais essenciais para o adequado desenvolvimento e exercício pleno e consciente das duas faculdades morais.

(II) As liberdades de movimento e livre escolha de ocupação sobre um fundo de oportunidades diversificadas, oportunidades estas que propiciam a busca de uma variedade de objetivos e tornam possíveis as decisões de revê-los e alterá-los.

(III) Os poderes e prerrogativas de cargos e posições de autoridade e responsabilidade.

(IV) Renda e riqueza, entendidas como meios polivalentes (que têm valor de troca) geralmente necessários para atingir uma ampla gama de objetivos, sejam eles quais forem.

(V) As bases sociais do auto-respeito, entendidas como aqueles aspectos das instituições básicas normalmente essenciais para que os cidadãos possam ter um senso vívido de seu valor enquanto pessoas e serem capazes de levar adiante seus objetivos com autoconfiança. ${ }^{330}$

\section{Rawls completa:}

A fim de destacar o caráter objetivo dos bens primários, note-se que não é o auto-respeito enquanto atitude para consigo mesmo, mas as bases sociais do auto-respeito que contam como bem primário. Essas bases sociais são coisas assemelhadas ao fato institucional de que os cidadãos têm direitos básicos iguais, e o reconhecimento público desse fato e de que todos endossam o princípio de diferença, ele mesmo uma forma de reciprocidade. (...) Bens primários são, portanto, aquilo de que pessoas livres e iguais (conforme especificado pela concepção política) precisam como cidadãos. ${ }^{331}$

\section{Rawls define os menos favorecidos da seguinte maneira:}

as desigualdades a que se aplica o princípio de diferença são diferenças nas expectativas (razoáveis) de bens primários dos cidadãos ao longo da vida toda. Essas expectativas são suas perspectivas de vida. Numa sociedade bem-ordenada, em que todos os direitos e liberdades básicos e iguais dos cidadãos e suas oportunidades eqüitativas estão garantidos, os menos favorecidos são os que pertencem à classe de renda com expectativas mais baixas. ${ }^{332}$

No contexto dos conceitos acima expostos, como introduzir as ações afirmativas?

Vimos os dois princípios de justiça de Rawls, sendo que o segundo se desdobra em outros dois: o princípio da igualdade eqüitativa de oportunidades e o princípio da diferença. Vejamos o que Rawls chama de igualdade eqüitativa de oportunidades:

A idéia aqui é que as posições não devem estar abertas apenas de um modo formal, mas que todos devem ter uma oportunidade eqüitativa de atingi-las. À primeira vista, não fica claro o que isso significa, mas podemos dizer que aqueles com habilidades e talentos semelhantes devem ter chances semelhantes na vida. Mais especificamente, supondo que haja uma distribuição de dotes naturais, aqueles que estão no mesmo nível de talento e habilidade, e têm a mesma disposição para utilizá-los, devem ter as mesmas perspectivas de sucesso, independentemente de seu lugar inicial no

\footnotetext{
${ }^{330}$ RAWLS, John. Justiça como eqüidade - Uma reformulação. São Paulo: Martins Fontes, 2003, p. 82-83.

${ }^{331}$ Idem, 84-85

${ }^{332}$ Ibdem, p. 83.
} 
sistema social. Em todos os setores da sociedade deveria haver, de forma geral, iguais perspectivas de cultura e realização para todos os que são dotados e motivados de forma semelhante. As expectativas daqueles com as mesmas habilidades e aspirações não devem ser afetadas por sua classe social. $^{333}$

No caso de não haver igualdade eqüitativa de oportunidades, cabe reparações, ou ações afirmativas. Para Kerstenetzky a discriminação positiva é uma qualidade republicana compatível com o princípio da retificação ou reparação, ou seja, compatível com a concepção de justiça social ralwsiana, onde liberdades formais para se converterem em liberdades reais requerem distribuição reparatória de oportunidades. ${ }^{334}$

Também o princípio da diferença abre espaço para reparações, onde caberiam as ações afirmativas:

podemos observar que o princípio da diferença dá algum peso às considerações preferidas pelo princípio da reparação. De acordo com esse último princípio, desigualdades de nascimento e de dotes naturais são imerecidas, elas devem ser de alguma forma compensadas. ${ }^{335}$

\section{Críticas a John Rawls}

\section{Ronald Dworkin}

Segundo Gargarella, "os vínculos entre as concepções defendidas por Rawls e Dworkin em torno da justiça são claramente mais fortes que suas diferenças." ${ }^{336}$ Quanto às divergências, Dworkin diz que Rawls é insensível aos dons próprios de cada pessoa e não suficientemente sensível às ambições de cada um. O primeiro fato pode ser explicado da seguinte forma: Suponhamos duas pessoas, uma com salário maior, mas com graves afecções físicas, e outra com salário um pouco menor. Mesmo com salário maior, a primeira não pode pagar os remédios que necessita. Ainda que o princípio da diferença procure compensá-la, ela

\footnotetext{
${ }^{333}$ RAWLS, John. Uma teoria da justiça. São Paulo: Martins Fontes, 2002, p. 77.

${ }^{334}$ KERSTENETZKY, Célia Lessa. Desigualdade como questão política. Observatório da Cidadania, 2003.

Consulta na internet no endereço www.ibase.org.br/modulos=541, consulta em 10-01-2009.

${ }^{335}$ RAWLS, John. Op. cit. p. 107

${ }^{336}$ GARGARELLA, Roberto. As teorias da justiça depois de Rawls - Um breve manual de filosofia políltica. São Paulo: Martins Fontes, 2008, p. 65
} 
continua com encargos das quais outros estão isentos. Quanto ao segundo fato, pensemos no seguinte exemplo: duas pessoas começam com iguais talentos e iguais recursos materiais. A primeira decide trabalhar mais e a segunda trabalha menos e usa suas economias em atividades de consumo. As duas estariam em situação de desigualdade, e a segunda deveria ser beneficiada, pelo princípio da diferença. Para Dworkin, essa situação é insensível à ambição da primeira. Pelo princípio da diferença, permite que a segunda tenha uma vida mais consumista, se beneficie do trabalho extra da primeira, mas não permite que a primeira usufrua do plano de vida que decidiu seguir. ${ }^{337}$

Além dos pontos levantados acima, Dworkin dá um contra-exemplo teórico ao princípio da diferença, questionando se esse princípio é sempre aplicável:

\begin{abstract}
Imaginemos um sistema econômico como realmente justo. (...) Alguma catástrofe iminente (por exemplo), então, obriga as autoridades a escolher. As autoridades agem de modo que a situação do representante da pequena classe dos mais pobres piore muito pouco, ou de modo que a situação de todos os outros piore drasticamente e eles se tornem quase tão pobres quanto os mais pobres. Será que a justiça exige realmente tão grande perda para todos, menos os mais pobres, para que se evite que sofram uma perda bem pequena? Talvez seja resposta suficiente para tais perguntas que as circunstâncias desse tipo têm muito pouca probabilidade de surgir e que, de fato, o destino das diversas ordens econômicas está, ou pode ser facilmente encadeado para que as melhorias na classe dos mais pobres venham realmente acompanhadas por melhorias pelo menos nas outras classes imediatamente superiores a ela. Mas essa resposta não elimina a questão teórica de se, em todas as circunstâncias, é realmente a situação do grupo mais pobre que determina o que é justo. ${ }^{338}$
\end{abstract}

\title{
Gerald Cohen
}

Analisemos as críticas de Cohen a Rawls no que concerne aos incentivos relacionados ao princípio da diferença e em relação à estrutura básica da sociedade.

O princípio da diferença defende que desigualdades podem ocorrer desde que redundem no maior benefício possível para os membros menos privilegiados da sociedade. Isso significa que os mais talentosos podem se beneficiar de desigualdades (os benefícios consistiriam em incentivos) desde que seus talentos e esforços sirvam para melhorar a situação dos menos

\footnotetext{
${ }^{337}$ idem, p. 67

${ }^{338}$ DWORKIN, Ronald. Op. cit. p.149
} 
favorecidos. Cohen, distingue uma "interpretação estrita" e uma "interpretação frouxa" do princípio da diferença.

De acordo com a interpretação estrita, as desigualdades que beneficiam os 'high-fliers' do mercado de trabalho só são justificadas caso se possa demonstrar que, sem elas, os mais talentosos seriam incapazes de empregar seus talentos de forma a elevar o quinhão distributivo daqueles que estão na posição mínima. Na interpretação frouxa do princípio, os incentivos só são necessários porque os mais talentosos se recusariam a dar tudo de suas capacidades se tais incentivos não existissem. ${ }^{339}$

$\mathrm{Na}$ interpretação frouxa, os mais talentosos fariam uma espécie de "chantagem" com a sociedade, disponibilizando seus talentos somente se fossem beneficiados com vantagens econômicas.

$\mathrm{Na}$ opinião de Cohen, a concessão dessas vantagens econômicas implica ceder diretamente à chantagem dos mais poderosos, algo que deveria estar proibido na concepção [de justiça] analisada. $\mathrm{O}$ que é pior, agora justifica-se esse tipo de desigualdade em nome da justiça ${ }^{340}$

Vejamos um exemplo de como a "chantagem" pode ser feita, analisando primeiro um discurso impessoal, que é como costuma ser feito na discussão política:

As desigualdades econômicas se justificam quando melhoram materialmente a situação das pessoas que estão na pior posição. \{premissa maior, normativa\};

Quando a alíquota máxima do imposto de renda é de $40 \%$ (a) os mais talentosos e ricos produzem mais do que o fazem quando essa alíquota é de $60 \%$, e, (b) os que estão na pior posição, em conseqüência, têm sua situação material melhorada. \{Premissa menor, fatual\};

Portanto, a alíquota máxima de tributação não deve ser elevada de 40 para $60 \%{ }^{341}$

Quando são os próprios talentosos e ricos que proferem o discurso, este soaria da seguinte maneira:

se vocês elevarem o nível de tributação para as faixas mais elevadas de renda, nós (os mais talentosos) retiraremos nossa capacidade produtiva superior, o que terá por resultado a redução do quinhão distributivo de todos. ${ }^{342}$

\footnotetext{
${ }^{339}$ VITA, Álvaro de. O liberalismo igualitário. Sociedade democrática e justiça internacional. São Paulo: Martins Fontes, 2008, p.64.

${ }^{340}$ GARGARELLA, Roberto. Op. cit. p. 80.

${ }_{341}^{341}$ COHEN, 1992, apud. VITA, Álvaro de. Op. Cit. p.64-65.

${ }^{342}$ VITA, Álvaro de. Op. Cit. p.65.
} 
Esse tipo de chantagem, feita pelos mais poderosos, não passaria por um teste de aceitabilidade pela "comunidade de justificação":

Fomentamos uma comunidade desse tipo com nossos concidadãos quando nos dispomos a oferecer a eles justificações, para as políticas que defendemos, que se mantêm em pé mesmo variando-se as situações de 'quem profere' e 'quem ouve' o argumento. ${ }^{343}$

Quanto à segunda crítica, conforme Gargarella, Cohen defende a idéia de que, para que uma sociedade possa ser considerada justa, não basta - como pensa Rawls - que nela seja garantida a justiça de sua 'estrutura básica' (isto é, a justiça de suas principais instituições). Uma sociedade justa precisa de um certo éthos, requer que sejam justas também as escolhas pessoais dos indivíduos que a compõem. ${ }^{344}$

"Éthos" pode ser entendido como a concepção moral das pessoas. Assim, podemos falar de um éthos igualitário ou não. Uma sociedade justa deve ser aquela onde o éthos social corresponde às normas da justiça. Um exemplo de injustiça que escapa à estrutura básica de Rawls mas representa um tipo de éthos é o praticado em certas famílias, onde há tratamento diferenciado entre homens e mulheres, havendo sobrecarga de trabalho às mulheres, pois além de trabalharem fora, são as responsáveis pelas tarefas domésticas e pelos cuidados com os filhos.

\section{Amartya Sen}

O foco de Sen está nas liberdades que um dado sujeito desfruta. Para entendermos o que ele quer dizer com liberdades, precisamos conhecer os conceitos de funcionamentos (functionings) e capacidade.

O conceito de funcionamentos reflete as várias coisas que uma pessoa pode considerar valioso fazer ou ter. Os funcionamentos valorizados podem variar dos elementares, como ser adequadamente nutrido e livre de doenças evitáveis, a atividades ou estados pessoais muito complexos, como poder participar da vida da comunidade e ter respeito próprio.(...) A capacidade de uma pessoa consiste nas combinações alternativas de funcionamentos cuja realização é factível para ela. Portanto, a

\footnotetext{
${ }^{343}$ COHEN, 1992, apud. VITA, Álvaro de. Op. Cit. p.65.

${ }^{344}$ GARGARELLA, Roberto. Op. cit. p. 83-84.
} 
capacidade é um tipo de liberdade: a liberdade substantiva de realizar combinações alternativas de funcionamentos (ou, menos formalmente expresso, a liberdade para ter estilos de vida diversos). ${ }^{345}$

Desta forma, devemos avaliar o bem-estar do indivíduo em razão de sua capacidade, ou seja, de ele ter várias alternativas de vida para escolher. Por exemplo, uma pessoa abastada que escolhe jejuar pode estar na mesma situação que uma pessoa pobre que jejua por passar fome extrema, mas a pessoa abastada pode escolher entre comer e jejuar, o que lhe confere uma liberdade que a pessoa pobre e faminta não tem.

Conforme Sen, dadas as informações sobre pessoas necessitadas, a decisão de quem devemos favorecer dependerá de a qual das informações sobre as pessoas se dará maior peso.

Sen vai analisar as bases informacionais de algumas teorias tradicionais de ética e justiça social, em particular o utilitarismo, o libertarismo e a teoria de justiça de Rawls, argumentando que elas apresentam falhas graves se as liberdades substantivas individuais forem consideradas importantes $^{346}$.

Conforme Sen, o utilitarismo clássico define utilidade como prazer, felicidade ou satisfação, e tudo gira em torno dessas realizações mentais, sendo que o utilitarismo não tem interesse na distribuição das utilidades, mas na utilidade total de todos considerados em conjunto, acarretando uma base informacional restrita, o que constitui uma limitação significativa da ética utilitarista. Para o utilitarismo moderno, a utilidade seria "a satisfação de um desejo ou algum tipo de representação do comportamento de escolha de uma pessoa". De qualquer forma, continua a indiferença às liberdades substantivas, direitos e liberdades formais. ${ }^{347} \mathrm{O}$ libertarismo, para Sen, não se preocupa com a felicidade ou satisfação de desejos como faz o utilitarismo, mas sua base informacional consiste inteiramente em liberdades formais e direitos de vários tipos. ${ }^{348}$

\footnotetext{
${ }^{345}$ SEN, Amartya. Desenvolvimento como liberdade. São Paulo: Companhia das Letras, 2008, p. 95

${ }^{346}$ idem, p. 74

${ }^{347}$ idem, p. 75. Liberdades formais opõem-se a liberdades substantivas, no sentido de que as primeiras referem-se à igualdade formal, enquanto as liberdades substantivas referem-se a liberdades como estar livre da fome, da morbidez evitável, liberdades associadas a saber ler, escrever, ter participação política, etc.

${ }^{348}$ ibdem, p. 76
} 
(...)o libertarismo requer obediência a certas regras de liberdade formal e conduta correta, avaliando a situação por meio de informações sobre essa obediência. ${ }^{349}$

O fato, para Sen, é que a exclusão de informações faz diferença na abordagem avaliatória, o que pode comprometer a teoria de justiça em questão.

a verdadeira 'essência' de uma teoria da justiça pode, em grande medida, ser compreendida a partir de sua base informacional: que informações são - ou não são - consideradas diretamente importantes.(...) A base informacional das teorias normativas em geral, e das teorias de justiça em particular, tem importância decisiva, e pode ser o ponto de enfoque crucial em muitos debates sobre políticas práticas. ${ }^{350}$

Como o utilitarismo e o libertarismo não levam em consideração as situações de privação de cada indivíduo, mostram-se teorias com base informacional insuficiente, pois:

essas considerações [as situações de privação] requerem uma base informacional mais ampla, concentrada particularmente na capacidade de as pessoas escolherem a vida que elas com justiça valorizam. $^{351}$

Sen diz que para muitas finalidades avaliatórias, o espaço apropriado não é o das utilidades nem o dos bens primários de Rawls, mas o das liberdades substantivas - as capacidades - de escolher uma vida que se tem razão para valorizar. ${ }^{352}$

Se o objetivo é concentrar-se na oportunidade real de o indivíduo promover seus objetivos (como Rawls recomenda explicitamente), então será preciso levar em conta não apenas os bens primários que as pessoas possuem, mas também as características pessoais relevantes que governam a conversão de bens primários na capacidade de a pessoa promover seus objetivos. Por exemplo, uma pessoa fisicamente incapacitada pode possuir uma cesta de bens primários maior e ainda assim ter menos chance de levar uma vida normal (ou de promover seus objetivos) do que um indivíduo fisicamente capaz possuidor de uma cesta menor de bens primários. ${ }^{353}$

Logo, para Sen, uma proposta igualitária não deve se basear na igualdade de bens primários, mas na capacidade dos indivíduos de transformarem os recursos em liberdades. Os funcionamentos que vão constituir as liberdades são os mais variados e representam desde os mais complexos, como a conquista de auto-respeito até os funcionamentos mais básicos, como

\footnotetext{
${ }^{349}$ Ibdem, p.76

350 Ibdem, p.76

351 Ibdem, p.82

352 ibdem, p. 94

353 Ibdem, p.95
} 
uma condição nutricional adequada. A valorização dos funcionamentos varia conforme o tipo de sociedade.

Nos Estados Unidos e na Europa ocidental hoje em dia, uma família pode ter dificuldade para participar da vida da comunidade se não possuir alguns bens específicos (como telefone, televisão ou automóvel), que na vida comunitária em países pobres são desnecessários. Nessa análise, o enfoque tem de incidir sobre as liberdades geradas pelos bens, e não sobre os bens em si mesmos. ${ }^{354}$

É nesse sentido que Sen critica a objetividade do enfoque de Rawls nos bens primários. Para Sen o importante são as liberdades que o indivíduo desfruta, que não são as mesmas para cada indivíduo, mas as que se configuram no seu bem estar. Sen tem o mérito de sugerir uma avaliação não tão subjetiva como o utilitarismo, nem tão objetiva como a concepção de bens primários de Rawls.

Analisamos conceitos de justiça social e aspectos da teoria de justiça de Rawls. As ações afirmativas são endossáveis quando o princípio das liberdades iguais e o princípio da igualdade eqüitativa de oportunidades não estão satisfeitos. O princípio da diferença também endossa reparações, pois desigualdades de nascimento e de dotes naturais são imerecidas. $\mathrm{O}$ arcabouço teórico de Rawls enfrenta dificuldades quando confrontado com a aplicação prática dos pressupostos, fato apontado por alguns de seus críticos. Rawls lista quais seriam os bens primários para um indivíduo. Esta questão é fundamental para os legisladores e gestores do Estado Social, afinal, quais seriam os bens mínimos para cada pessoa, os quais poderíamos considerar suficientes para garantir a justiça social? A resposta não é clara, e diferentemente de Rawls, Amartya Sem relativiza esse rol de bens. O rol depende de quem é o indivíduo em questão, e de qual é a sociedade onde ele vive. Talvez esse caminho seja mais promissor na elaboração de leis e na gestão pública.

Passemos no próximo tópico a investigar a importância da justiça social na Constituição Federal do Brasil.

${ }^{354}$ Ibdem, p.94 


\title{
6.4. Justiça social e a Constituição Federal
}

\author{
Conforme Ferreira Filho:
}

\begin{abstract}
Até a Primeira Guerra Mundial, as Constituições só se preocupavam com a organização política. A essa regra abre exceção a revolucionária Constituição Mexicana de 1917 cuja influência imediata foi pequena. Na verdade, foram as Constituições do após-guerra, Weimar (1919) e outras, que procuravam acrescentar às Constituições normas que estendessem aos campos econômico e social os valores, se não os mecanismos, democráticos. Daí em diante, no Brasil, a partir de 1934, em geral se abriu espaço nas Constituições para a ordem econômica e social. ${ }^{355}$
\end{abstract}

A Constituição de 1969, anterior à Constituição vigente, tinha como fim da Ordem Econômica e Social a realização da Justiça Social:

“Art. 160. A ordem econômica e social tem por fim realizar o desenvolvimento nacional e a justiça social com base nos seguintes princípios:

I- liberdade de iniciativa;

II - valorização do trabalho como condição da dignidade humana;

III - função social da propriedade;

IV-harmonia e solidariedade entre as categorias sociais de produção;

$V$ - repressão ao abuso do poder econômico, caracterizado pelo domínio dos mercados, a eliminação da concorrência e o aumento arbitrário dos lucros;

VI - expansão das oportunidades de emprego produtivo."

$\mathrm{Na}$ Constituição Federal do Brasil a justiça social mostra-se como uma meta do Estado. Vejamos sua expressão no artigo 170, sobre a ordem econômica, no artigo 193, sobre a ordem social:

"Art. 170. A ordem econômica, fundada na valorização do trabalho humano e na livre iniciativa, tem por fim assegurar a todos existência digna, conforme os ditames da justiça social, observados os seguintes princípios:

${ }^{355}$ FERREIRA FILHO, Manoel Gonçalves. Curso de Direito Constitucional. São Paulo: Saraiva, 2006, p. 356357. 
I- soberania nacional;

II- propriedade privada;

III- função social da propriedade;

IV- livre concorrência;

$V$ - defesa do consumidor;

VI- defesa do meio ambiente, inclusive mediante tratamento diferenciado conforme o impacto ambiental dos produtos e serviços e de seus processos de elaboração e prestação;

VII- redução das desigualdades regionais e sociais;

VIII- Busca do pleno emprego;

$I X$ - tratamento favorecido para as empresas de pequeno porte constituidas sob as leis brasileiras e que tenham sua sede e administração no País. "

E:

"Art. 193. A ordem social tem como base o primado do trabalho, e como objetivo o bemestar e a justiça sociais."

A justiça social encontra grande destaque nesses dois artigos. A Ordem Econômica tem por fim assegurar a todos existência digna, conforme ditames da Justiça social, ou seja, a justiça social é condição para a Ordem Econômica alcançar seu fỉm.. A Ordem Social tem como objetivo claro a justiça social. Para a Ordem Econômica a justiça social é condição, para a Ordem Social, é objetivo. Nesse contexto, conforme Tércio Sampaio Ferraz Jr., os valores econômicos são valores-meio, e os sociais, valores-fim. ${ }^{356}$

Ferreira Filho observa que a atual Constituição, no que tange à justiça social, mostra influência nítida da doutrina social da Igreja Católica, particularmente dos documentos pontifícios mais recentes, como a Mater et Magistra. ${ }^{357}$ Citemos o artigo 71 do referido documento, para exemplificar as preocupações com justiça social:

\footnotetext{
${ }^{356}$ FERRAZ JR., Tercio Sampaio, DINIZ, Maria Helena, GEORGAKILAS, Ritinha A. Stevenson. Constituição de 1988, Legitimidade, Vigência e Eficácia, Supremacia. Atlas: São Paulo, 1989, p. 52.

${ }^{357}$ FERREIRA FILHO, Manoel Gonçalves. Op. Cit. p. 357.
} 
"71. Julgamos, pois, dever nosso armar uma vez mais que a retribuição do trabalho, assim como não pode ser inteiramente abandonada às leis do mercado, também não pode fixar-se arbitrariamente; há de estabelecer-se segundo a justiça e a eqüidade. É necessário que aos trabalhadores se dê um salário que lhes proporcione um nivel de vida verdadeiramente humano e lhes permita enfrentar com dignidade as responsabilidades familiares. É preciso igualmente que, ao determinar-se a retribuição, se tenham em conta o concurso efetivo dos trabalhadores para a produção, as condições econômicas das empresas e as exigências do bem comum nacional. Considerem-se de modo especial as repercussões sobre o emprego global das forças de trabalho dentro do país inteiro, e ainda as exigências do bem comum universal, isto é, as que dizem respeito às comunidades internacionais, de natureza e extensão diversas."

Examinando o artigo 170 da Constituição, observamos que a ordem econômica deve estar em conformidade com a justiça social, observados determinados princípios. Segundo Junkes:

sem a observância desses princípios - contidos nos nove incisos do art. 170 da Constituição - e da valorização do trabalho humano, da livre iniciativa e do asseguramento da existência digna a todos - princípios contidos no caput do mencionado artigo - não é possível na ordem econômica, concretizar a justiça social. ${ }^{358}$

Examinemos esses princípios. Quanto à “valorização do trabalho humano”, esclarece Ferreira Filho:

$\mathrm{Na}$ verdade, o trabalho é ao mesmo tempo um direito e uma obrigação de cada indivíduo. Como direito, deflui diretamente do direito à vida. Para viver, tem o homem de trabalhar. A ordem econômica que lhe rejeitar o trabalho, lhe recusa o direito a sobreviver. Como obrigação, deriva do fato de viver o homem em sociedade, de tal sorte que o todo depende da colaboração de cada um. ${ }^{359}$

\section{Para Bastos:}

Cremos que o Texto Constitucional refere-se à valorização do trabalho humano no sentido também material que a expressão possui. É dizer: o trabalho deve fazer jus a uma contrapartida monetária

\footnotetext{
358 JUNKES, Sérgio Luiz. Defensoria Pública e o Princípio da Justiça Social. Curitiba: Juruá, 2006, p. 67-68.

${ }^{359}$ FERREIRA FILHO, Manoel Gonçalves. Op. Cit. p. 359.
} 
que o torne materialmente digno. $\mathrm{O}$ trabalho prestado mediante pagamentos vis tangencia a servidão e não é compatível com o estágio sócio-econômico dos nossos dias. ${ }^{360}$

O que decorre dos autores acima referidos é que a valorização do trabalho implica que o trabalho é um direito do ser humano e como tal deve ser valorizado, também, é a forma de sobrevivência do ser humano, logo, seu valor material deve garantir a existência digna, outro princípio aludido no caput do artigo 170.

Quanto à "livre iniciativa", para Bastos, "equivale ao direito que todos têm de lançaremse ao mercado de produção de bens e serviços por sua conta e risco. Aliás, ou autores reconhecem que a liberdade de iniciar a atividade econômica implica a de gestão e a de empresa. ${ }^{״ 61} \mathrm{~A}$ livre iniciativa implica no direito à propriedade:"A liberdade de iniciativa e de empresa pressupõe o direito de propriedade da mesma sorte que é de certa forma uma decorrência deste." ${ }^{362}$

A liberdade de iniciativa, associada aos princípios de propriedade privada (art. 170, inciso II) e de livre concorrência (art. 170, inciso IV), configuram uma economia de mercado, ou seja, o sistema econômico capitalista.

O terceiro princípio no caput do artigo 170 é o de uma "existência digna", que a ordem econômica deve satisfazer. Para Bastos:

Com efeito, o fim último da atividade econômica é a satisfação das necessidades da coletividade. $O$ estágio atual da tecnologia e do equipamento industrial, agrícola e de serviços já começa a tornar possível eliminar o que tem sido uma constante na história da humanidade: a existência da pobreza. Embora países como o nosso não se encontrem bem posicionados em termos de erradicação da pobreza, não há dúvida que essa é uma meta em tese alcançável em tempo relativamente curto se forem conjugadas medidas de desenvolvimento econômico acelerado com expedientes voltados à redistribuição da riqueza" 363

Será possível organizar-se a justiça social dentro de um regime de liberdade de iniciativa? Bastos não vê contradição entre essas idéias:

\footnotetext{
${ }^{360}$ BASTOS, Celso Ribeiro, MARTINS, Ives Gandra. Comentários à constituição do Brasil. São Paulo: Saraiva, $1990,7^{\circ}$ volume, p. 16.

${ }^{361}$ Idem, p. 16.

${ }^{362}$ Idem, p. 16.

${ }^{363}$ Ibdem, p. 17-18.
} 
A nosso ver não existe uma contradição visceral entre essas idéias. É certo que jogadas a si mesmas as forças da produção podem caminhar num sentido inverso ao da justiça, contudo, ainda assim, os Estados que mais têm avançado na melhoria da condição humana são justamente aqueles que adotam a liberdade de iniciativa. Ao Estado pode caber um papel redistribuidor da renda nacional. E é até indispensável que ele o exerça. O que não é aceitável é ver-se uma contradição entre a liberdade de iniciativa e a justiça social a ponto de afirmar que esta última só é atingível na medida em que se negue a primeira. ${ }^{364}$

José Afonso da Silva mostra-se pessimista quanto à realização da justiça social num sistema capitalista:

Assegurar a todos existência digna, conforme os ditames da justiça social, não será tarefa fácil num sistema de base capitalista e, pois, essencialmente individualista. É que a justiça social só se realiza mediante eqüitativa distribuição da riqueza. Um regime de acumulação ou de concentração do capital e da renda nacional, que resulta da apropriação privada dos meios de produção, não propicia efetiva justiça social, porque nele sempre se manifesta grande diversidade de classe social, com amplas camadas de população carente ao lado de minoria afortunada. A história mostra que a injustiça é inerente ao modo de produção capitalista, mormente do capitalismo periférico. Algumas providências constitucionais formam agora um conjunto de direitos sociais com mecanismos de concreção que devidamente utilizados podem tornar menos abstrata a promessa de justiça social. Esta é realmente uma determinante essencial que impõe e obriga que todas as demais regras da constituição econômica sejam entendidas e operadas em função dela. ${ }^{365}$

O princípio da "soberania nacional" (art. 170, inciso I), nos diz que o país não deve ter sua economia submetida à gerência externa. Note-se, porém, que os países hoje são interdependentes economicamente, o que não pode ocorrer é que o direito do país à autodeterminação seja desrespeitado. Notemos que a soberania é fundamento da República Federativa do Brasil (art. $1^{\circ}$, inciso I).

O princípio seguinte, o da "propriedade privada" (art. 170. inciso II) está no rol dos direitos fundamentais, mas submete-se ao princípio da função social da propriedade (art. 170, inciso III). Conforme Bastos:

É certo que hoje a propriedade não pode mais ser entendida com o mesmo conteúdo que tinha no século XVIII e mesmo no XIX. Nessa ocasião houve o apogeu da ideologia individualista, que levou a uma exacerbação do direito de propriedade. Muitas vezes ela era utilizada de forma a satisfazer os caprichos do proprietário, sem nenhuma contribuição, contudo, para o bem-estar da coletividade. Não é mais esta propriedade privada que é assegurada pelo Texto Constitucional.

\footnotetext{
${ }^{364}$ Ibdem, p. 18

365 SILVA, José Afonso. Curso de Direito Constitucional Positivo. São Paulo: Malheiros Editores, 2000, p. 767.
} 
Atualmente o que se assegura é a propriedade simultaneamente propiciadora de gozo e fruição pelo seu titular e geradora de uma utilidade coletivamente fruível. ${ }^{366}$

O princípio da "livre concorrência" (art. 170, inciso IV) garante que todos possam concorrer no mercado com seus serviços e produtos. Na verdade a livre concorrência só existe em alguns setores da economia, mas esse princípio serve para nortear o Estado no sentido de coibir abusos do poder econômico.

O princípio da "defesa do consumidor" (art. 170, inciso V) prevê que o consumidor é a parte mais frágil na relação de consumo, cabendo ao Estado garantir-lhe proteção e direitos. Também o inciso XXXII do art. $5^{\circ}$ da Constituição tem como norma a defesa do consumidor.

O princípio de "defesa do meio-ambiente" na ordem econômica (art.170, inciso VI) prevê que a atividade econômica pode ser destruidora do meio-ambiente, colocando em risco a sobrevivência da humanidade. A atividade econômica deve desenvolver-se respeitando o meio-ambiente, tanto que o referido inciso prevê tratamento diferenciado "conforme o impacto ambiental dos produtos e serviços e de seus processos de elaboração e prestação". O artigo 225 da Constituição garante o direito a um meio-ambiente equilibrado.

O princípio da "redução das desigualdades regionais e sociais" é plenamente coerente com os objetivos da justiça social, a qual visa diminuir as desigualdades. Conforme Bastos:

Vê-se assim que o desenvolvimento há de ser devidamente compartilhado por todos. O nosso país apresenta problemas de desequiparações acentuadas de rendas em dois níveis diferentes: no regional e no social. Cada um deles deverá ser objeto de políticas adequadas. ${ }^{367}$

O princípio da "busca do pleno emprego" (art. 170, inciso VIII) é um meio de levar ao crescimento e desenvolvimento econômico. Além disso, o pleno emprego melhora as condições de vida dos trabalhadores, pois havendo oferta plena de trabalho, há melhores salários. Conforme Ferreira Filho, "não basta valorizar o trabalho, é necessário, em

\footnotetext{
${ }^{366}$ BASTOS, Celso Ribeiro, MARTINS, Ives Gandra. Op. Cit. p. 21-22.

${ }^{367}$ Idem, p. 32.
} 
sociedades como a nossa, criar oportunidades de trabalho, para que todos possam viver dignamente, do próprio esforço." 368

Por fim temos o princípio de "tratamento favorecido para as empresas de pequeno porte constituidas sob as leis brasileiras e que tenham sua sede e administração no País”, (art. 170, inciso IX). Essas empresas desempenham papel fundamental na criação de empregos, exercício da livre iniciativa, e da livre concorrência. Conforme Ferreira Filho, "Numa era de gigantismo empresarial, a sobrevivência das empresas de pequeno porte é extremamente difícil. São elas, porém, um elemento de equilíbrio e, conseqüentemente, merecem um tratamento especial."369

\section{Conforme Bastos:}

Nos dias atuais é muito freqüente reconhecer-se a importância desempenhada pelas pequenas e microempresas. São essas as responsáveis pelo maior número de empregos. De outra parte são um instrumento útil para a democratização do capital, assim como para a criação de estímulos a que um maior número de pessoas se lance à atividade empresarial. ${ }^{370}$

Quanto à justiça social na ordem social, nos diz Tércio Sampaio:

Consagrando valores-fim, a Ordem Social visa à justiça social. Esta expressão nos permite delinear o público e o privado no espaço da sociabilidade. Entendemos por espaço da sociabilidade aquela esfera híbrida, na qual os interesses privados assumem importância pública. Trata-se de uma instituição da era moderna, cuja raiz primordial é a unicidade da humanidade, o lugar em que o processo vital comum se organiza publicamente. Isto ocorre, historicamente, no momento em que o trabalho enquanto força de trabalho se emancipa da esfera privada e conquista um caráter público, o que certamente coincide em parte com a ascensão política das classes trabalhadoras. Nesta nova esfera, a vida é o supremo bem. Por isso, em termos de legitimidade da ordem, o risco é que aí impere um único interesse, cujo sujeito é uma abstração: a espécie humana ou a coletividade uniforme e conformemente submissa. É aí que entra o sentido legitimante da justiça social.

Seu conteúdo está nas relações humanas enquanto relação entre seres que sobrevivem pela sua própria força de trabalho e seu problema é constituí-los em igualdade como pessoas e não como abstrações. Constituí-los como pessoas significa ao mesmo tempo reconhecê-los como distintos e, ao mesmo tempo, igualados pela condição de sobrevivência. Igualá-los pela condição da sobrevivência quer dizer reconhecer que, na esfera da sociabilidade, os homens têm um destino comum: a própria vida. Reconhecê-los como distintos é atribuir-lhes, naquela mesma esfera, um principio de independência em relação aos instrumentos da sobrevivência, é não colocá-los, os homens, coletivamente, a serviço da vida. Nestes termos, justiça social é disciplina valorativa da

\footnotetext{
${ }^{368}$ FERREIRA FILHO, Manoel Gonçalves. Op. Cit. p. 360.

${ }^{369}$ Ibdem, p. 360.

${ }^{370}$ BASTOS, Celso Ribeiro, MARTINS, Ives Gandra. Op. Cit. p. 36.
} 
sociedade, de modo que, na esfera da sociabilidade, o público e o privado tenham garantidos os seus traços próprios e não se reduzam um ao outro.

Em termos de justiça social, o público, na sociabilidade, deve ser a esfera do coletivo, mas não do político e do poder. Não se confunde (nem os absorve) com procedimentos de representação popular ou de iniciativa direta no exercício do governo, embora possa neles repercutir e até lhes impor demandas próprias. A justiça social significa um delineamento do público como uma esfera de demandas sociais comuns, conforme um princípio de participação e igualdade nas organizações sociais. ${ }^{371}$

${ }^{371}$ FERRAZ JR., Tercio Sampaio, DINIZ, Maria Helena, GEORGAKILAS, Ritinha A. Stevenson. Constituição de 1988, Legitimidade, Vigência e Eficácia, Supremacia. Atlas: São Paulo:1989, p. 53-54. 


\section{Experiências das ações afirmativas nas Instituições Públicas de Ensino Superior (IPES) brasileiras - 2008}

No presente capítulo examinaremos as ações afirmativas e os critérios que os gestores de Instituições Públicas de Ensino Superior (IPES) estão utilizando para aplicá-las. Primeiro veremos as ações afirmativas em 81 universidades pesquisadas, onde poderemos observar as ações afirmativas para a população negra, objeto do nosso estudo. Os dados foram resumidos na tabela 3 - Relação das ações afirmativas nas Instituições Públicas de Ensino Superior 2008. No tópico seguinte do capítulo será feita uma análise dos critérios utilizados para a implementação das ações afirmativas.

7.1. Relação das ações afirmativas em Instituições Públicas de Ensino Superior (IPES) brasileiras - levantamento no $2^{\circ}$ semestre de 2008

Tabela 3 - Relação das ações afirmativas nas Instituições Públicas de Ensino Superior - 2008

\begin{tabular}{|c|c|c|}
\hline Estado/Universidade & Descrição das ações afirmativas & Fontes \\
\hline \multicolumn{3}{|l|}{ Rio Grande do Sul } \\
\hline $\begin{array}{l}1 . \\
\text { Universidade } \\
\text { Federal de Santa } \\
\text { Maria - UFSM }\end{array}$ & $\begin{array}{l}.11 \% \text { das vagas para } \\
\text { afrobrasileiros (nascidos no } \\
\text { Brasil), e não afrodescendentes; } \\
.20 \% \text { das vagas para alunos } \\
\text { provenientes de escola pública; } \\
.5 \% \text { das vagas para alunos com } \\
\text { necessidades especiais; } \\
.08 \text { vagas para indígenas. }\end{array}$ & $\begin{array}{l}\text { Edital 009/2008 e Resolução } \\
\text { 011/2007 COPERVES } \\
\underline{\text { http://www.ufsm.br/ }} \\
\underline{\text { http://coperves.proj.ufsm.br/? }} \\
\underline{\text { noticia=135 }}\end{array}$ \\
\hline
\end{tabular}




\begin{tabular}{|c|c|c|}
\hline Estado/Universidade & Descrição das ações afirmativas & Fontes \\
\hline $\begin{array}{l}2 . \\
\text { Universidade } \\
\text { Federal do Pampa - } \\
\text { UNIPAMPA }\end{array}$ & $\begin{array}{l}.6 \% \text { das vagas para candidatos } \\
\text { com necessidades especiais; } \\
.30 \% \text { das vagas para oriundos } \\
\text { das escolas públicas; } \\
.10 \% \text { para oriundos das escolas } \\
\text { públicas, autodeclarados negros; } \\
.4 \% \text { para indígenas, oriundos } \\
\text { das escolas públicas. }\end{array}$ & $\begin{array}{l}\text { EDITAL N. }{ }^{\circ} 043, \text { DE } 12 \text { DE } \\
\text { NOVEMBRO DE } 2008 \\
\text { http://www.unipampa.edu.br/ } \\
\text { portal/index.php/vestibular }\end{array}$ \\
\hline $\begin{array}{l}3 . \\
\text { Universidade } \\
\text { Federal do Rio } \\
\text { Grande do Sul - } \\
\text { UFRGS }\end{array}$ & $\begin{array}{l}30 \% \text { das vagas para oriundos de } \\
\text { escolas públicas, dessas, metade } \\
\text { para autodeclarados negros }\end{array}$ & $\begin{array}{l}\text { Decisão 134/2007 do } \\
\text { CONSUN } \\
\text { http://www.vestibular.ufrgs.br } \\
\text { lcv2009/EDITAL DE ABER } \\
\text { TURA_DE INSCRICOES_FI } \\
\text { NAL2009.doc }\end{array}$ \\
\hline $\begin{array}{l}4 . \\
\text { Universidade } \\
\text { Estadual do Rio } \\
\text { Grande do Sul - } \\
\text { UERGS }\end{array}$ & $\begin{array}{l}.50 \% \text { das vagas para candidatos } \\
\text { hipossuficientes, com } \\
\text { renda mensal pessoal menor ou } \\
\text { igual a R } \$ 477,40 ; \\
.10 \% \text { das vagas para candidatos } \\
\text { portadores de deficiências } \\
\text { físicas. }\end{array}$ & 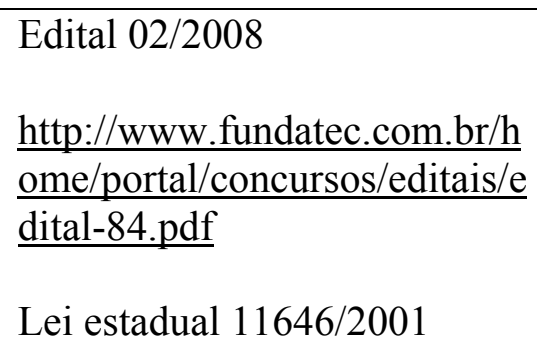 \\
\hline \multicolumn{3}{|l|}{ Santa Catarina } \\
\hline $\begin{array}{l}5 . \\
\text { Universidade } \\
\text { Federal de Santa } \\
\text { Catarina - UFSC }\end{array}$ & $\begin{array}{l}.20 \% \text { das vagas para alunos que } \\
\text { tenham cursado integralmente o } \\
\text { ensino fundamental e médio em } \\
\text { instituições públicas; } \\
.10 \% \text { das vagas para negros que } \\
\text { tenham cursado integralmente o } \\
\text { ensino fundamental e médio em } \\
\text { instituições públicas; } \\
.6 \text { vagas para indígenas. }\end{array}$ & $\begin{array}{l}\text { Resolução 8/CUN/2007 } \\
\text { http://www.vestibular2009.ufs } \\
\begin{array}{l}\text { c.br/PAA_orientacoes_basicas } \\
\text {.pdf }\end{array} \\
\begin{array}{l}\text { http://www.vestibular2009.ufs } \\
\text { c.br/resolucao acoes afirmati }\end{array} \\
\text { vas.pdf }\end{array}$ \\
\hline $\begin{array}{l}6 . \\
\text { Centro Universitário } \\
\text { de São José - USJ }\end{array}$ & $\begin{array}{l}.70 \% \text { das vagas para oriundos } \\
\text { de escola pública de São José }\end{array}$ & $\begin{array}{l}\text { http://www.usj.edu.br/templat } \\
\text { es/52/conteudo_visualizar_din } \\
\text { amico.jsp?idConteudo=3491 } \\
\& \text { idUser }=24241320 \& \text { idEmpre } \\
\text { sa }=57 \& \text { tituloConteudo=Lein } \\
\text { 4.310de06dejunhode2005.\&ar } \\
\text { ea }=1\end{array}$ \\
\hline
\end{tabular}




\begin{tabular}{|c|c|c|}
\hline Estado/Universidade & Descrição das ações afirmativas & Fontes \\
\hline \multicolumn{3}{|l|}{ Paraná } \\
\hline $\begin{array}{l}7 . \\
\text { Universidade } \\
\text { Tecnológica Federal } \\
\text { do Paraná - UTFPR }\end{array}$ & $\begin{array}{l}50 \% \text { das vagas para egressos de } \\
\text { escola pública, tendo cursado } \\
\text { todas as séries do ensino médio } \\
\text { em escola pública }\end{array}$ & $\begin{array}{l}\text { Edital 30/2008 - CAFCV } \\
\underline{\text { http://200.19.73.111/ves/pg/ed }} \\
\underline{\text { ital/edital_ves_ver_2009.pdf }}\end{array}$ \\
\hline $\begin{array}{l}8 . \\
\text { Universidade } \\
\text { Federal do Paraná - } \\
\text { UFPR }\end{array}$ & $\begin{array}{l}.20 \% \text { das vagas para negros; } \\
.20 \% \text { das vagas para egressos da } \\
\text { escola pública; } \\
\text { em cada curso haverá uma vaga } \\
\text { destinada para pessoas com } \\
\text { deficiência. }\end{array}$ & $\begin{array}{l}\text { Resolução 17/07 COUN e } \\
\text { 37/04 COUN } \\
\text { http://www.ufpr.br/soc/pesqui } \\
\text { sa.php?conselho=\&item=Resu } \\
\text { ltado da } \\
\text { Pesquisa\&searchword=cotas }\end{array}$ \\
\hline $\begin{array}{l}9 . \\
\text { Universidade } \\
\text { Estadual de Ponta } \\
\text { Grossa - UEPG }\end{array}$ & $\begin{array}{l}\text {.Os percentuais de vagas } \\
\text { ofertadas aplicáveis ao sistema } \\
\text { de cotas serão proporcionais à } \\
\text { quantidade de inscritos por } \\
\text { curso, sendo no mínimo } 10 \% \\
\text { das vagas para egressos da } \\
\text { escola pública e } 5 \% \text { das vagas } \\
\text { para negros oriundos de escolas } \\
\text { públicas; } \\
.6 \text { vagas para indígenas de } \\
\text { tribos paranaenses. }\end{array}$ & $\begin{array}{l}\text { Lei Estadual 14995/2006 } \\
\text { http://www.uepg.br/cps/Docu } \\
\underline{\text { mentos/2008/manves092.pdf }}\end{array}$ \\
\hline $\begin{array}{l}10 . \\
\text { Universidade } \\
\text { Estadual de } \\
\text { Londrina - UEL }\end{array}$ & $\begin{array}{l}.20 \% \text { das vagas para egressos da } \\
\text { escola pública; } \\
.20 \% \text { das vagas para negros } \\
\text { oriundos de escola pública; } \\
.6 \text { vagas para indígenas de } \\
\text { tribos paranaenses. }\end{array}$ & $\begin{array}{l}\text { Lei Estadual 14995/2006 } \\
\underline{\text { http://www.cops.uel.br/vestib }} \\
\underline{\text { ular/2009/arquivos/RESOLU }} \\
\underline{\text { CAO_CEPE_81_2008.PDF }}\end{array}$ \\
\hline $\begin{array}{l}11 . \\
\text { Universidade } \\
\text { Estadual de Maringá } \\
\text { - UEM }\end{array}$ & $\begin{array}{l}.20 \% \text { das vagas para egressos da } \\
\text { escola pública, que tenham } \\
\text { cursado integralmente o ensino } \\
\text { fundamental e médio, limite } \\
\text { máximo de renda individual } 1,5 \\
\text { salário mínimo ; } \\
.6 \text { vagas para indígenas } \\
\text { oriundos de tribos paranaenses }\end{array}$ & $\underline{\text { http://www.cvu.uem.br/cotas. }}$ \\
\hline
\end{tabular}




\begin{tabular}{|c|c|c|}
\hline Estado/Universidade & Descrição das ações afirmativas & Fontes \\
\hline $\begin{array}{l}12 . \\
\text { Universidade } \\
\text { Estadual do } \\
\text { Centro Oeste - } \\
\text { UNICENTRO }\end{array}$ & $\begin{array}{l}6 \text { vagas para indígenas oriundos } \\
\text { de tribos paranaenses }\end{array}$ & $\begin{array}{l}\text { Lei Estadual 14995/2006 } \\
\text { http://www.unicentro.br/vesti } \\
\text { bularindigena/universidades.a } \\
\underline{\text { sp }} \\
\text { http://celepar7cta.pr.gov.br/S } \\
\underline{\text { EEG/sumulas.nsf/319b106715 }} \\
\underline{\text { f69a4b03256efc00601826/8bb }} \\
\text { aae6aa6864d59832570f9005d } \\
\text { 9115?OpenDocument }\end{array}$ \\
\hline $\begin{array}{l}13 . \\
\text { Universidade } \\
\text { Estadual do } \\
\text { Oeste do } \\
\text { Paraná - } \\
\text { UNIOESTE }\end{array}$ & $\begin{array}{l}.6 \text { vagas para indígenas } \\
\text { oriundos de tribos paranaenses; } \\
.40 \% \text { das vagas para alunos } \\
\text { oriundos de escola pública, que } \\
\text { cursaram as quatro séries finais } \\
\text { do Ensino Fundamental ( } 5^{\mathrm{a}} \text { a } 8^{\mathrm{a}} \\
\text { séries) e o Ensino Médio em } \\
\text { escola pública. }\end{array}$ & $\begin{array}{l}\text { Lei Estadual 14995/2006 } \\
\text { http://celepar7cta.pr.gov.br/S } \\
\begin{array}{l}\text { EEG/sumulas.nsf/319b106715 } \\
\text { f69a4b03256efc00601826/8bb } \\
\text { aae6aa6864d59832570f9005d } \\
\text { 9115?OpenDocument } \\
\text { http://www.unioeste.br/vestib } \\
\text { ular/ }\end{array}\end{array}$ \\
\hline $\begin{array}{l}14 . \\
\text { Universidade } \\
\text { Estadual do } \\
\text { Paraná - } \\
\text { UNESPAR }\end{array}$ & $\begin{array}{l}6 \text { vagas para indígenas oriundos } \\
\text { de tribos paranaenses }\end{array}$ & $\begin{array}{l}\text { Lei Estadual 14995/2006 } \\
\text { http://celepar7cta.pr.gov.br/S } \\
\begin{array}{l}\text { EEG/sumulas.nsf/319b106715 } \\
\text { f69a4b03256efc00601826/8bb } \\
\text { aae6aa6864d59832570f9005d } \\
\text { 9115?OpenDocument }\end{array}\end{array}$ \\
\hline $\begin{array}{l}15 . \\
\text { Universidade } \\
\text { Estadual do } \\
\text { Norte do } \\
\text { Paraná - UENP }\end{array}$ & $\begin{array}{l}6 \text { vagas para indígenas oriundos } \\
\text { de tribos paranaenses }\end{array}$ & $\begin{array}{l}\text { Lei Estadual 14995/2006 } \\
\text { http://celepar7cta.pr.gov.br/S } \\
\text { EEG/sumulas.nsf/319b106715 } \\
\text { f69a4b03256efc00601826/8bb } \\
\text { aae6a66864d59832570f9005d } \\
\text { 9115?OpenDocument }\end{array}$ \\
\hline
\end{tabular}




\begin{tabular}{|c|c|c|}
\hline Estado/Universidade & Descrição das ações afirmativas & Fontes \\
\hline $\begin{array}{l}16 . \\
\text { Escola de Música e } \\
\text { Belas Artes do } \\
\text { Paraná - EMBAP }\end{array}$ & $\begin{array}{l}6 \text { vagas para indígenas oriundos } \\
\text { de tribos paranaenses }\end{array}$ & $\begin{array}{l}\text { Lei Estadual 14995/2006 } \\
\text { http://celepar7cta.pr.gov.br/S } \\
\text { EEG/sumulas.nsf/319b106715 } \\
\text { f69a4b03256efc00601826/8bb } \\
\text { aae6aa6864d59832570f9005d } \\
\text { 9115?OpenDocument } \\
\text { http://www.embap.pr.gov.br/a } \\
\text { rquivos/File/graduacao.pdf }\end{array}$ \\
\hline $\begin{array}{l}17 . \\
\text { Faculdade Estadual } \\
\text { de Ciências } \\
\text { Econômicas de } \\
\text { Apucarana - FECEA }\end{array}$ & $\begin{array}{l}6 \text { vagas para indígenas oriundos } \\
\text { de tribos paranaenses }\end{array}$ & 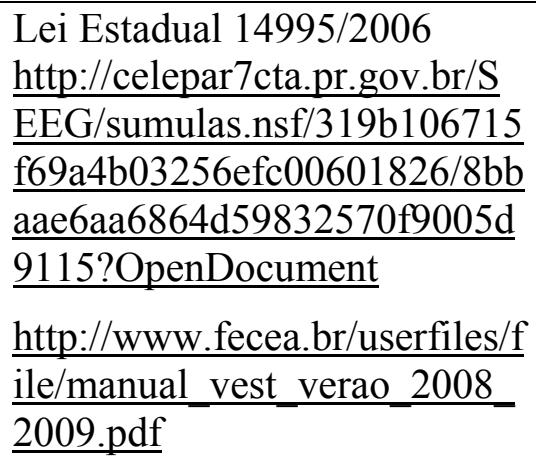 \\
\hline $\begin{array}{l}18 . \\
\text { Faculdade de } \\
\text { Ciências e Letras de } \\
\text { Campo Mourão - } \\
\text { FECILCAM }\end{array}$ & $\begin{array}{l}6 \text { vagas para indígenas oriundos } \\
\text { de tribos paranaenses }\end{array}$ & 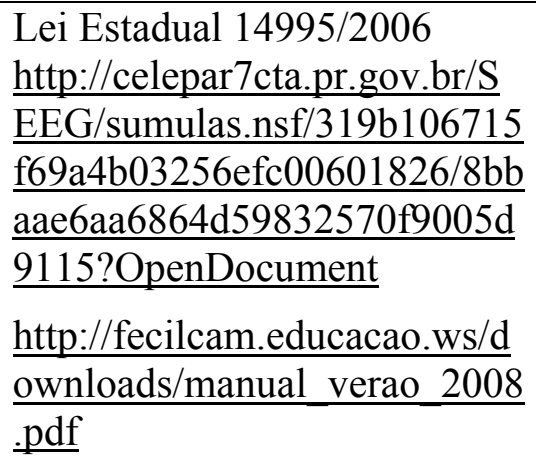 \\
\hline $\begin{array}{l}19 . \\
\text { Faculdade Estadual } \\
\text { de Educação, } \\
\text { Ciências e Letras de } \\
\text { Paranavai - PR - } \\
\text { FAFIPA }\end{array}$ & $\begin{array}{l}6 \text { vagas para indígenas oriundos } \\
\text { de tribos paranaenses }\end{array}$ & $\begin{array}{l}\text { Lei Estadual 14995/2006 } \\
\text { http://celepar7cta.pr.gov.br/S } \\
\text { EEG/sumulas.nsf/319b106715 } \\
\text { f69a4b03256efc00601826/8bb } \\
\text { aae6aa6864d59832570f9005d } \\
\text { 9115?OpenDocument } \\
\text { http://200.203.233.3/fafipa/cc } \\
\text { v/vestibular/verao2009/manua } \\
\text { lcandidato.pdf }\end{array}$ \\
\hline
\end{tabular}




\begin{tabular}{|c|c|c|}
\hline Estado/Universidade & Descrição das ações afirmativas & Fontes \\
\hline $\begin{array}{l}20 . \\
\text { Faculdade Estadual } \\
\text { de Filosofia, } \\
\text { Ciências e Letras de } \\
\text { Paranaguá - } \\
\text { FAFIPAR }\end{array}$ & $\begin{array}{l}6 \text { vagas para indígenas oriundos } \\
\text { de tribos paranaenses }\end{array}$ & $\begin{array}{l}\text { Lei Estadual 14995/2006 } \\
\text { http://celepar7cta.pr.gov.br/S } \\
\text { EEG/sumulas.nsf/319b106715 } \\
\text { f69a4b03256efc00601826/8bb } \\
\text { aae6aa6864d59832570f9005d } \\
\text { 9115?OpenDocument } \\
\text { http://www.seti.gov.br/ies/ind } \\
\text { ex.htm } \\
\text { http://www.educacaosuperior. } \\
\text { inep.gov.br/funcional/info_ies } \\
\text { new.asp?pIES=725 }\end{array}$ \\
\hline $\begin{array}{l}21 . \\
\text { Faculdade Estadual } \\
\text { de Filosofia, } \\
\text { Ciências e Letras } \\
\text { União da Vitória - } \\
\text { Paraná - FAFI }\end{array}$ & $\begin{array}{l}6 \text { vagas para indígenas oriundos } \\
\text { de tribos paranaenses }\end{array}$ & $\begin{array}{l}\text { Lei Estadual 14995/2006 } \\
\text { http://celepar7cta.pr.gov.br/S } \\
\text { EEG/sumulas.nsf/319b106715 } \\
\text { f69a4b03256efc00601826/8bb } \\
\text { aae6aa6864d59832570f9005d } \\
\text { 9115?OpenDocument } \\
\text { http://www.fafiuv.br/img/vesti } \\
\text { bularverao2008/MANUAL\%2 } \\
\text { 0CANDIDATO\%20VESTIB } \\
\text { ULAR\%20VERAO\%202008. } \\
\text { pdf }\end{array}$ \\
\hline \multicolumn{3}{|l|}{ MINAS GERAIS } \\
\hline $\begin{array}{l}22 . \\
\text { Universidade } \\
\text { Federal de Juiz de } \\
\text { Fora - UFJF }\end{array}$ & $\begin{array}{l}50 \% \text { das vagas para os egressos } \\
\text { das escolas públicas, e, dentro } \\
\text { deste percentual, uma reserva de } \\
25 \% \text { das vagas para candidatos } \\
\text { autodeclarados negros }\end{array}$ & $\begin{array}{l}\text { Resolução } 05 / 2005 \text { do } \\
\text { Conselho Superior da UFJF } \\
\text { http://siga4.ufjf.br/index.php? } \\
\text { module=vestibular\&action=ht } \\
\text { ml:files:edital2009:edital.pdf }\end{array}$ \\
\hline
\end{tabular}




\begin{tabular}{|c|c|c|}
\hline Estado/Universidade & Descrição das ações afirmativas & Fontes \\
\hline $\begin{array}{l}23 . \\
\text { Universidade } \\
\text { Estadual de Montes } \\
\text { Claros - } \\
\text { UNIMONTES }\end{array}$ & $\begin{array}{l}.20 \% \text { das vagas para } \\
\text { afrodescendentes . com renda } \\
\text { individual até um salário } \\
\text { mínimo, base setembro/2008; } \\
.20 \% \text { das vagas para estudantes } \\
\text { oriundos da escola pública com } \\
\text { renda individual até um salário } \\
\text { mínimo, base setembro/2008; } \\
.5 \% \text { das vagas para indígenas e } \\
\text { deficientes. }\end{array}$ & 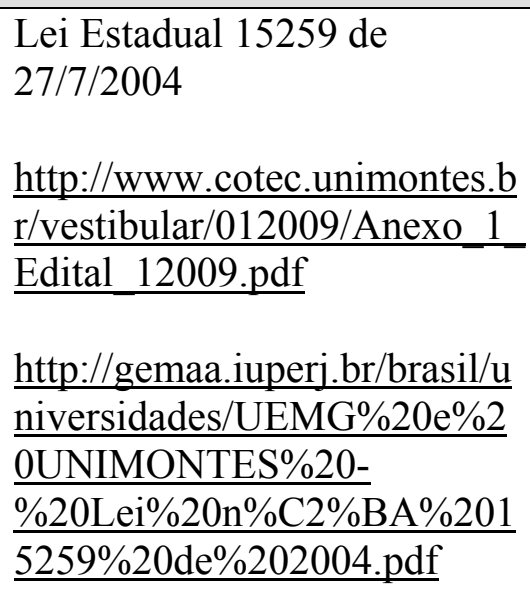 \\
\hline $\begin{array}{l}24 . \\
\text { Universidade do } \\
\text { Estado de Minas } \\
\text { Gerais - UEMG }\end{array}$ & $\begin{array}{l}.20 \% \text { das vagas para } \\
\text { afrodescendentes . com renda } \\
\text { individual até um salário } \\
\text { mínimo, base setembro/2008; } \\
.20 \% \text { das vagas para estudantes } \\
\text { oriundos da escola pública com } \\
\text { renda individual até um salário } \\
\text { mínimo, base setembro/2008; } \\
.5 \% \text { das vagas para indígenas e } \\
\text { deficientes. }\end{array}$ & 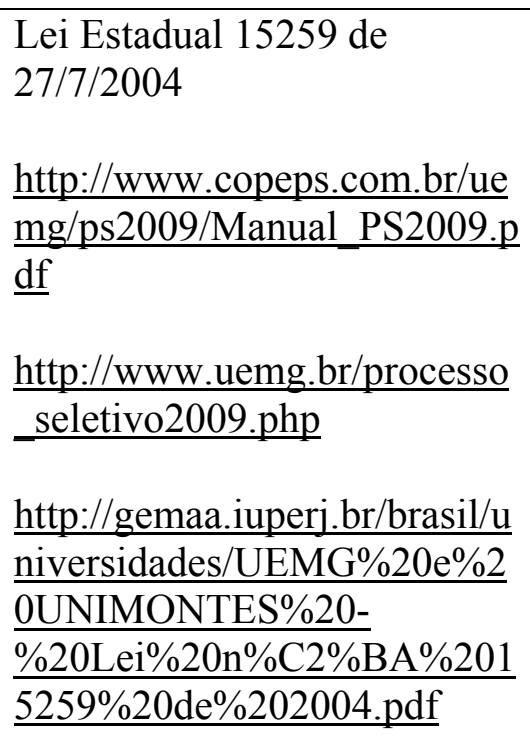 \\
\hline $\begin{array}{l}25 . \\
\text { Universidade } \\
\text { Federal de } \\
\text { Uberlândia - UFU }\end{array}$ & $\begin{array}{l}25 \% \text { das vagas para oriundos da } \\
\text { escola pública }\end{array}$ & $\begin{array}{l}\text { RESOLUÇÃO No 20/2008, DO } \\
\text { CONSELHO UNIVERSITÁRIO } \\
\text { http://www.ingresso.ufu.br/co } \\
\text { pev/paaes/Resolucao_20_200 } \\
8 \text { cria PAAES.PDF }\end{array}$ \\
\hline $\begin{array}{l}26 . \\
\text { Universidade } \\
\text { Federal de Ouro } \\
\text { Preto - UFOP }\end{array}$ & $\begin{array}{l}30 \% \text { das vagas para oriundos da } \\
\text { escola pública }\end{array}$ & $\begin{array}{l}\text { Edital COPEPS 02/2008 } \\
\text { http://www.vestibular.ufop.br/ } \\
\underline{\text { downloads/vestibulares/manu }} \\
\underline{\text { ais/manual_do_candidatof09- }}\end{array}$ \\
\hline
\end{tabular}




\begin{tabular}{|c|c|c|}
\hline Estado/Universidade & Descrição das ações afirmativas & Fontes \\
\hline \multicolumn{3}{|l|}{ ESPIRITO SANTO } \\
\hline $\begin{array}{l}27 . \\
\text { Universidade } \\
\text { Federal do Espírito } \\
\text { Santo - UFES }\end{array}$ & $\begin{array}{l}45 \% \text { das vagas para egressos } \\
\text { das escolas públicas, com renda } \\
\text { familiar de até } 7 \text { (sete) salários } \\
\text { mínimos mensais }\end{array}$ & $\begin{array}{l}\text { Resolução 33/2007 CEPE } \\
\text { alterada pela resolução } \\
\text { 31/2008 } \\
\text { http://www.ccv.ufes.br/ }\end{array}$ \\
\hline \multicolumn{3}{|l|}{ RIO DE JANEIRO } \\
\hline $\begin{array}{l}28 . \\
\text { Universidade } \\
\text { Federal Fluminense } \\
\text { - UFF }\end{array}$ & $\begin{array}{l}\text {.Bônus de } 10 \% \text { (dez por cento) } \\
\text { a ser aplicado sobre a nota final } \\
\text { do concurso (somatório das } \\
\text { notas da primeira e da segunda } \\
\text { etapa) do candidato que } \\
\text { tenha concluído ou esteja por } \\
\text { concluir em } 2008 \text { todo o Ensino } \\
\text { Médio em escola pública } \\
\text { estadual ou municipal de } \\
\text { qualquer unidade da federação, } \\
\text { excetuando-se os colégios } \\
\text { federais, universitários, } \\
\text { militares e de aplicação. } \\
\text {.Política de Reserva de Vagas } \\
\text { de } 20 \% \text { para professores da } \\
\text { rede pública de ensino, apenas } \\
\text { para o curso de Licenciatura } \\
\text { Noturna em Matemática, Física } \\
\text { e Química. }\end{array}$ & $\begin{array}{l}\text { Resolução } 177 / 2008 \text { do } \\
\text { Conselho de Ensino e } \\
\text { Pesquisa } \\
\text { http://www.coseac.uff.br/2009 } \\
\text { L }\end{array}$ \\
\hline $\begin{array}{l}29 . \\
\text { Instituto Superior } \\
\text { de Educação da } \\
\text { Zona Oeste - ISE } \\
\text { ZONA OESTE }\end{array}$ & $\begin{array}{l}45 \% \text { das vagas a candidatos } \\
\text { carentes (candidatos com renda } \\
\text { máxima individual de } \mathrm{R} \$ \\
960,00 \text { ) distribuídas da seguinte } \\
\text { forma: } \\
\text { I) } 20 \% \text { para estudantes oriundos } \\
\text { da rede pública de ensino; } \\
\text { II) } 20 \% \text { para estudantes de cor } \\
\text { de pele negra, autodeclarados; } \\
\text { III) } 5 \% \text { para pessoas com } \\
\text { deficiência, nos termos da } \\
\text { legislação em vigor, integrantes } \\
\text { de minorias étnicas, filhos de } \\
\text { policiais civis, militares, } \\
\text { bombeiros militares e de } \\
\text { inspetores de segurança e } \\
\text { administração penitenciária, } \\
\text { mortos em razão do serviço. }\end{array}$ & $\begin{array}{l}\text { Pelas Leis Estaduais } \\
4151 / 2003 \text { e } 5074 / 2007, \\
\underline{\text { http://alerjln1.alerj.rj.gov.br/C }} \\
\underline{\text { ONTLEI.NSF/e9589b9aabd9c }} \\
\underline{\text { ac8032564fe0065abb4/59b59 }} \\
\underline{\text { 003123eb2c08325733a006eb0 }} \\
\underline{97 ? \text { OpenDocument }}\end{array}$ \\
\hline
\end{tabular}




\begin{tabular}{|c|c|c|}
\hline Estado/Universidade & Descrição das ações afirmativas & Fontes \\
\hline $\begin{array}{l}30 . \\
\text { Instituto Superior } \\
\text { de Educação de } \\
\text { Santo Antônio de } \\
\text { Pádua - ISE Pádua }\end{array}$ & $\begin{array}{l}45 \% \text { das vagas a candidatos } \\
\text { carentes (candidatos com renda } \\
\text { máxima individual de } \mathrm{R} \$ \\
960,00 \text { ) distribuídas da seguinte } \\
\text { forma: } \\
\text { I) } 20 \% \text { para estudantes oriundos } \\
\text { da rede pública de ensino; } \\
\text { II) } 20 \% \text { para estudantes de cor } \\
\text { de pele negra, autodeclarados; } \\
\text { III) } 5 \% \text { para pessoas com } \\
\text { deficiência, nos termos da } \\
\text { legislação em vigor, integrantes } \\
\text { de minorias étnicas, filhos de } \\
\text { policiais civis, militares, } \\
\text { bombeiros militares e de } \\
\text { inspetores de segurança e } \\
\text { administração penitenciária, } \\
\text { mortos em razão do serviço. }\end{array}$ & $\begin{array}{l}\text { Pelas Leis Estaduais } \\
\text { 4151/2003 e 5074/2007, } \\
\underline{\text { http://alerjln1.alerj.rj.gov.br/C }} \\
\underline{\text { ONTLEI.NSF/e9589b9aabd9c }} \\
\underline{\text { ac8032564fe0065abb4/59b59 }} \\
\underline{\text { 003123eb2c08325733a006eb0 }} \\
\underline{\text { 97?OpenDocument }}\end{array}$ \\
\hline $\begin{array}{l}31 . \\
\text { Instituto Superior } \\
\text { de Educação do Rio } \\
\text { de Janeiro - ISERJ }\end{array}$ & $\begin{array}{l}45 \% \text { das vagas a candidatos } \\
\text { carentes (candidatos com renda } \\
\text { máxima individual de } \mathrm{R} \$ \\
960,00 \text { ) distribuídas da seguinte } \\
\text { forma: } \\
\text { I) } 20 \% \text { para estudantes oriundos } \\
\text { da rede pública de ensino; } \\
\text { II) } 20 \% \text { para estudantes de cor } \\
\text { de pele negra, autodeclarados; } \\
\text { III) } 5 \% \text { para pessoas com } \\
\text { deficiência, nos termos da } \\
\text { legislação em vigor, integrantes } \\
\text { de minorias étnicas, filhos de } \\
\text { policiais civis, militares, } \\
\text { bombeiros militares e de } \\
\text { inspetores de segurança e } \\
\text { administração penitenciária, } \\
\text { mortos em razão do serviço. }\end{array}$ & $\begin{array}{l}\text { Pelas Leis Estaduais } \\
4151 / 2003 \text { e } 5074 / 2007, \\
\underline{\text { http://alerjln1.alerj.rj.gov.br/C }} \\
\underline{\text { ONTLEI.NSF/e9589b9aabd9c }} \\
\underline{\text { ac8032564fe0065abb4/59b59 }} \\
\underline{\text { 003123eb2c08325733a006eb0 }} \\
\underline{97 ? \text { OpenDocument }}\end{array}$ \\
\hline
\end{tabular}




\begin{tabular}{|c|c|c|}
\hline Estado/Universidade & Descrição das ações afirmativas & Fontes \\
\hline $\begin{array}{l}32 . \\
\text { Instituto Superior de } \\
\text { Educação } \\
\text { Professor Aldo } \\
\text { Muylaert - ISEPAM }\end{array}$ & $\begin{array}{l}45 \% \text { das vagas a candidatos } \\
\text { carentes (candidatos com renda } \\
\text { máxima individual de } \mathrm{R} \$ \\
960,00 \text { ) distribuídas da seguinte } \\
\text { forma: } \\
\text { I) } 20 \% \text { para estudantes oriundos } \\
\text { da rede pública de ensino; } \\
\text { II) } 20 \% \text { para estudantes de cor } \\
\text { de pele negra, autodeclarados; } \\
\text { III) } 5 \% \text { para pessoas com } \\
\text { deficiência, nos termos da } \\
\text { legislação em vigor, integrantes } \\
\text { de minorias étnicas, filhos de } \\
\text { policiais civis, militares, } \\
\text { bombeiros militares e de } \\
\text { inspetores de segurança e } \\
\text { administração penitenciária, } \\
\text { mortos em razão do serviço. }\end{array}$ & $\begin{array}{l}\text { Pelas Leis Estaduais } \\
\text { 4151/2003 e 5074/2007, } \\
\underline{\text { http://alerjln1.alerj.rj.gov.br/C }} \\
\underline{\text { ONTLEI.NSF/e9589b9aabd9c }} \\
\underline{\text { ac8032564fe0065abb4/59b59 }} \\
\underline{\text { 003123eb2c08325733a006eb0 }} \\
\underline{\text { 97?OpenDocument }}\end{array}$ \\
\hline $\begin{array}{l}33 . \\
\text { Instituto Superior de } \\
\text { Educação Três Rios } \\
\text { - } \\
\text { ISE TRÊS RIOS }\end{array}$ & $\begin{array}{l}45 \% \text { das vagas a candidatos } \\
\text { carentes (candidatos com renda } \\
\text { máxima individual de } \mathrm{R} \$ \\
960,00 \text { ) distribuídas da seguinte } \\
\text { forma: } \\
\text { I) } 20 \% \text { para estudantes oriundos } \\
\text { da rede pública de ensino; } \\
\text { II) } 20 \% \text { para estudantes de cor } \\
\text { de pele negra, autodeclarados; } \\
\text { III) } 5 \% \text { para pessoas com } \\
\text { deficiência, nos termos da } \\
\text { legislação em vigor, integrantes } \\
\text { de minorias étnicas, filhos de } \\
\text { policiais civis, militares, } \\
\text { bombeiros militares e de } \\
\text { inspetores de segurança e } \\
\text { administração penitenciária, } \\
\text { mortos em razão do serviço. }\end{array}$ & $\begin{array}{l}\text { Pelas Leis Estaduais } \\
4151 / 2003 \text { e } 5074 / 2007, \\
\underline{\text { http://alerjln1.alerj.rj.gov.br/C }} \\
\underline{\text { ONTLEI.NSF/e9589b9aabd9c }} \\
\underline{\text { ac8032564fe0065abb4/59b59 }} \\
\underline{\text { 003123eb2c08325733a006eb0 }} \\
\underline{97 ? \text { OpenDocument }}\end{array}$ \\
\hline
\end{tabular}




\begin{tabular}{|c|c|c|}
\hline Estado/Universidade & Descrição das ações afirmativas & Fontes \\
\hline $\begin{array}{l}34 . \\
\text { Instituto Superior } \\
\text { de Tecnologia em } \\
\text { Ciência da } \\
\text { Informação de } \\
\text { Petrópolis - ISTCCP }\end{array}$ & $\begin{array}{l}45 \% \text { das vagas a candidatos } \\
\text { carentes (candidatos com renda } \\
\text { máxima individual de } \mathrm{R} \$ \\
960,00 \text { ) distribuídas da seguinte } \\
\text { forma: } \\
\text { I) } 20 \% \text { para estudantes oriundos } \\
\text { da rede pública de ensino; } \\
\text { II) } 20 \% \text { para estudantes de cor } \\
\text { de pele negra, autodeclarados; } \\
\text { III) } 5 \% \text { para pessoas com } \\
\text { deficiência, nos termos da } \\
\text { legislação em vigor, integrantes } \\
\text { de minorias étnicas, filhos de } \\
\text { policiais civis, militares, } \\
\text { bombeiros militares e de } \\
\text { inspetores de segurança e } \\
\text { administração penitenciária, } \\
\text { mortos em razão do serviço. }\end{array}$ & $\begin{array}{l}\text { Pelas Leis Estaduais } \\
4151 / 2003 \text { e } 5074 / 2007, \\
\underline{\text { http://alerjln1.alerj.rj.gov.br/C }} \\
\underline{\text { ONTLEI.NSF/e9589b9aabd9c }} \\
\underline{\text { ac8032564fe0065abb4/59b59 }} \\
\underline{\text { 903123eb2c08325733a006eb0 }}\end{array}$ \\
\hline $\begin{array}{l}35 . \\
\text { Instituto Superior } \\
\text { de Tecnologia em } \\
\text { Ciências da } \\
\text { Computação do Rio } \\
\text { de Janeiro - IST-RIO }\end{array}$ & $\begin{array}{l}45 \% \text { das vagas a candidatos } \\
\text { carentes (candidatos com renda } \\
\text { máxima individual de R } \$ \\
960,00 \text { ) distribuídas da seguinte } \\
\text { forma: } \\
\text { I) } 20 \% \text { para estudantes oriundos } \\
\text { da rede pública de ensino; } \\
\text { II) } 20 \% \text { para estudantes de cor } \\
\text { de pele negra, autodeclarados; } \\
\text { III) } 5 \% \text { para pessoas com } \\
\text { deficiência, nos termos da } \\
\text { legislação em vigor, integrantes } \\
\text { de minorias étnicas, filhos de } \\
\text { policiais civis, militares, } \\
\text { bombeiros militares e de } \\
\text { inspetores de segurança e } \\
\text { administração penitenciária, } \\
\text { mortos em razão do serviço. }\end{array}$ & $\begin{array}{l}\text { Pelas Leis Estaduais } \\
4151 / 2003 \text { e } 5074 / 2007, \\
\frac{\text { http://alerjln1.aleri.rj.gov.br/C }}{\underline{\text { ONTLEI.NSF/e9589b9aabd9c }}} \\
\underline{\text { ac8032564fe0065abb4/59b59 }} \\
\underline{\text { 003123eb2c08325733a006eb0 }} \\
\underline{97 \text { OpenDocument }}\end{array}$ \\
\hline
\end{tabular}




\begin{tabular}{|c|c|c|}
\hline Estado/Universidade & Descrição das ações afirmativas & Fontes \\
\hline $\begin{array}{l}36 . \\
\text { Instituto Superior de } \\
\text { Tecnologia em } \\
\text { Horticultura - } \\
\text { IST- } \\
\text { HORTICULTURA }\end{array}$ & $\begin{array}{l}45 \% \text { das vagas a candidatos } \\
\text { carentes (candidatos com renda } \\
\text { máxima individual de } \mathrm{R} \$ \\
960,00 \text { ) distribuídas da seguinte } \\
\text { forma: } \\
\text { I) } 20 \% \text { para estudantes oriundos } \\
\text { da rede pública de ensino; } \\
\text { II) } 20 \% \text { para estudantes de cor } \\
\text { de pele negra, autodeclarados; } \\
\text { III) } 5 \% \text { para pessoas com } \\
\text { deficiência, nos termos da } \\
\text { legislação em vigor, integrantes } \\
\text { de minorias étnicas, filhos de } \\
\text { policiais civis, militares, } \\
\text { bombeiros militares e de } \\
\text { inspetores de segurança e } \\
\text { administração penitenciária, } \\
\text { mortos em razão do serviço. }\end{array}$ & $\begin{array}{l}\text { Pelas Leis Estaduais } \\
4151 / 2003 \text { e } 5074 / 2007, \\
\underline{\text { http://alerjln1.alerj.rj.gov.br/C }} \\
\underline{\text { ONTLEI.NSF/e9589b9aabd9c }} \\
\underline{\text { ac8032564fe0065abb4/59b59 }} \\
\underline{\text { 903123eb2c08325733a006eb0 }}\end{array}$ \\
\hline $\begin{array}{l}37 . \\
\text { Instituto Superior } \\
\text { Tecnológico de } \\
\text { Paracambi - IST } \\
\text { PARACAMBI }\end{array}$ & $\begin{array}{l}45 \% \text { das vagas a candidatos } \\
\text { carentes (candidatos com renda } \\
\text { máxima individual de } \mathrm{R} \$ \\
960,00 \text { ) distribuídas da seguinte } \\
\text { forma: } \\
\text { I) } 20 \% \text { para estudantes oriundos } \\
\text { da rede pública de ensino; } \\
\text { II) } 20 \% \text { para estudantes de cor } \\
\text { de pele negra, autodeclarados; } \\
\text { III) } 5 \% \text { para pessoas com } \\
\text { deficiência, nos termos da } \\
\text { legislação em vigor, integrantes } \\
\text { de minorias étnicas, filhos de } \\
\text { policiais civis, militares, } \\
\text { bombeiros militares e de } \\
\text { inspetores de segurança e } \\
\text { administração penitenciária, } \\
\text { mortos em razão do serviço. }\end{array}$ & $\begin{array}{l}\text { Pelas Leis Estaduais } \\
4151 / 2003 \text { e } 5074 / 2007, \\
\underline{\text { http://aleriln1.alerj.rj.gov.br/C }} \\
\underline{\text { ONTLEI.NSF/e9589b9aabd9c }} \\
\underline{\text { ac8032564fe0065abb4/59b59 }} \\
\underline{\text { 003123eb2c08325733a006eb0 }}\end{array}$ \\
\hline
\end{tabular}




\begin{tabular}{|c|c|c|}
\hline Estado/Universidade & Descrição das ações afirmativas & Fontes \\
\hline $\begin{array}{l}38 . \\
\text { Universidade } \\
\text { Estadual do Norte } \\
\text { Fluminense Darcy } \\
\text { Ribeiro - UENF }\end{array}$ & $\begin{array}{l}45 \% \text { das vagas a candidatos } \\
\text { carentes (candidatos com renda } \\
\text { máxima individual de R } \$ \\
960,00 \text { ) distribuídas da seguinte } \\
\text { forma: } \\
\text { I) } 20 \% \text { para estudantes oriundos } \\
\text { da rede pública de ensino; } \\
\text { II) } 20 \% \text { para estudantes de cor } \\
\text { de pele negra, autodeclarados; } \\
\text { III) } 5 \% \text { para pessoas com } \\
\text { deficiência, nos termos da } \\
\text { legislação em vigor, integrantes } \\
\text { de minorias étnicas, filhos de } \\
\text { policiais civis, militares, } \\
\text { bombeiros militares e de } \\
\text { inspetores de segurança e } \\
\text { administração penitenciária, } \\
\text { mortos em razão do serviço.. }\end{array}$ & $\begin{array}{l}\text { Pelas Leis Estaduais } \\
4151 / 2003 \text { e } 5074 / 2007, \\
\text { http://alerjln1.alerj.rj.gov.br/C } \\
\underline{\text { ONTLEI.NSF/e9589b9aabd9c }} \\
\underline{\text { ac8032564fe0065abb4/59b59 }} \\
\underline{\text { 003123eb2c08325733a006eb0 }} \\
\underline{97 ? \text { OpenDocument }}\end{array}$ \\
\hline $\begin{array}{l}39 . \\
\text { Universidade do } \\
\text { Estado do Rio de } \\
\text { Janeiro - UERJ }\end{array}$ & $\begin{array}{l}45 \% \text { das vagas a candidatos } \\
\text { carentes (candidatos com renda } \\
\text { máxima individual de } \mathrm{R} \$ \\
960,00 \text { ) distribuídas da seguinte } \\
\text { forma: } \\
\text { I) } 20 \% \text { para estudantes oriundos } \\
\text { da rede pública de ensino; } \\
\text { II) } 20 \% \text { para estudantes de cor } \\
\text { de pele negra, autodeclarados; } \\
\text { III) } 5 \% \text { para pessoas com } \\
\text { deficiência, nos termos da } \\
\text { legislação em vigor, integrantes } \\
\text { de minorias étnicas, filhos de } \\
\text { policiais civis, militares, } \\
\text { bombeiros militares e de } \\
\text { inspetores de segurança e } \\
\text { administração penitenciária, } \\
\text { mortos em razão do serviço. }\end{array}$ & $\begin{array}{l}\text { Pelas Leis Estaduais } \\
4151 / 2003 \text { e 5074/2007, } \\
\underline{\text { http://alerjln1.alerj.rj.gov.br/C }} \\
\underline{\text { ONTLEI.NSF/e9589b9aabd9c }} \\
\underline{\text { ac8032564fe0065abb4/59b59 }} \\
\underline{\text { 003123eb2c08325733a006eb0 }} \\
\underline{97 \text { OpenDocument }}\end{array}$ \\
\hline
\end{tabular}




\begin{tabular}{|c|c|c|}
\hline Estado/Universidade & Descrição das ações afirmativas & Fontes \\
\hline $\begin{array}{l}40 . \\
\text { Centro } \\
\text { Universitário } \\
\text { Estadual da Zona } \\
\text { Oeste - UEZO }\end{array}$ & $\begin{array}{l}45 \% \text { das vagas a candidatos } \\
\text { carentes (candidatos com renda } \\
\text { máxima individual de R } \$ \\
960,00 \text { ) distribuídas da seguinte } \\
\text { forma: } \\
\text { I) } 20 \% \text { para estudantes oriundos } \\
\text { da rede pública de ensino; } \\
\text { II) } 20 \% \text { para estudantes de cor } \\
\text { de pele negra, autodeclarados; } \\
\text { III) } 5 \% \text { para pessoas com } \\
\text { deficiência, nos termos da } \\
\text { legislação em vigor, integrantes } \\
\text { de minorias étnicas, fillhos de } \\
\text { policiais civis, militares, } \\
\text { bombeiros militares e de } \\
\text { inspetores de segurança e } \\
\text { administração penitenciária, } \\
\text { mortos em razão do serviço. }\end{array}$ & 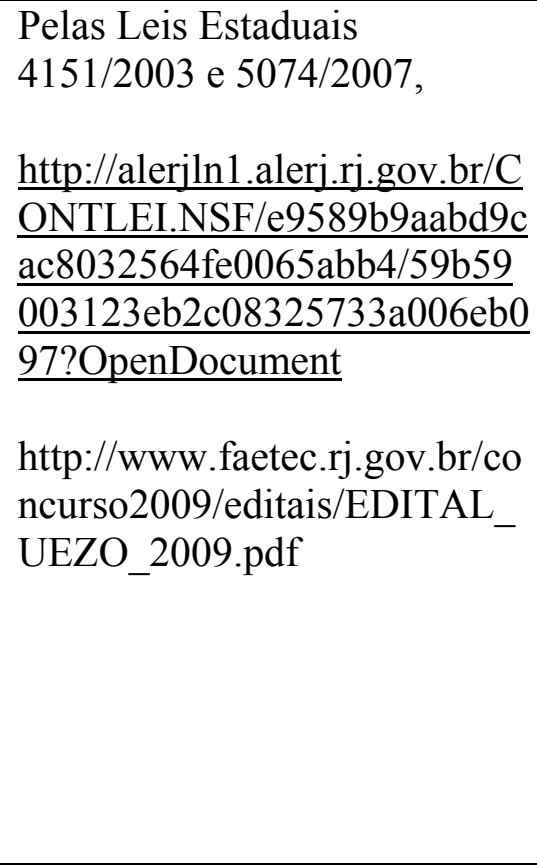 \\
\hline \multicolumn{3}{|l|}{ SÃO PAULO } \\
\hline $\begin{array}{l}41 . \\
\text { Universidade } \\
\text { Federal de São } \\
\text { Carlos - UFSCAR }\end{array}$ & $\begin{array}{l}\text { De } 2008 \text { a } 2010: 20 \% \text { das vagas } \\
\text { para egressos de escolas } \\
\text { públicas e escolas indígenas, } \\
\text { deste percentual da reserva de } \\
\text { vagas, } 35 \% \text { serão ocupados por } \\
\text { negros e } 1 \% \text { por indígenas. }\end{array}$ & $\begin{array}{l}\text { Portaria CEPE 586/2008 } \\
\text { http://www.acoesafirmativas.u } \\
\text { fscar.br/arquivos/proposta-de- } \\
\text { programa-de-acoes- } \\
\text { afirmativas-para-a-ufscar- } \\
\text { versao-final }\end{array}$ \\
\hline $\begin{array}{l}42 . \\
\text { Universidade } \\
\text { Federal de São } \\
\text { Paulo - UNIFESP }\end{array}$ & $\begin{array}{l}\text { Adicional de } 10 \% \text { ao número de } \\
\text { vagas para candidatos de cor } \\
\text { (ou raça) preta, parda ou } \\
\text { indígena, oriundos do ensino } \\
\text { público. }\end{array}$ & $\begin{array}{l}\text { Resolução } \mathrm{n}^{\circ} 47, \text { de } 11 \text { de } \\
\text { junho de } 2008 \\
\text { http://www.unifesp.br/prograd } \\
\text { pestibular/portal/index.php?o } \\
\text { ption=com content\&task=vie } \\
\text { w\&id=107\&Itemid=2 }\end{array}$ \\
\hline
\end{tabular}




\begin{tabular}{|c|c|c|}
\hline Estado/Universidade & Descrição das ações afirmativas & Fontes \\
\hline $\begin{array}{l}43 . \\
\text { Fundação } \\
\text { Universidade } \\
\text { Federal do ABC - } \\
\text { UFABC }\end{array}$ & $\begin{array}{l}\text { De } 1500 \text { vagas: } \\
.500 \text { vagas para sistema ENEM, } \\
\text { dessas, } 250 \text { ou } 50 \% \text { reservadas } \\
\text { para alunos oriundos de escola } \\
\text { pública, das quais são } \\
\text { reservadas } 71 \text { (setenta e uma) } \\
\text { vagas, para os candidatos que se } \\
\text { autodeclararem negros e } 1 \\
\text { (uma) vaga para indígena; } \\
.1000 \text { vagas para sistema } \\
\text { vestibular, dessas } 50 \% \text { ou } 500 \\
\text { vagas para alunos oriundos de } \\
\text { escola pública, das quais são } \\
\text { reservadas } 142 \text { (cento e } \\
\text { quarenta e duas) vagas para os } \\
\text { candidatos que se auto-- } \\
\text { declararem negros e } 1 \text { vaga para } \\
\text { indígena; }\end{array}$ & $\begin{array}{l}\text { EDITAL PS 01/08- } \\
\text { PROCESSO SELETIVO } \\
\text { PARA INGRESSO } 2009 \\
\text { http://www.ufabc.edu.br/inde } \\
\underline{\text { x.php?option=com content\&V }} \\
\underline{\text { iew }=\text { article\&id }=543 \& \text { Itemid }=} \\
\underline{224}\end{array}$ \\
\hline $\begin{array}{l}44 . \\
\text { Unicamp } \\
\text { (Universidade } \\
\text { Estadual de } \\
\text { Campinas) }\end{array}$ & $\begin{array}{l}\text { Após a } 2^{\mathrm{a}} \text { fase do vestibular, } \\
\text { acréscimo de } 30 \text { pontos à Nota } \\
\text { Padronizada de Opção (NPO) } \\
\text { para candidatos que tenham } \\
\text { cursado integralmente o ensino } \\
\text { médio em escolas públicas. } \\
\text { Desses, aqueles que se } \\
\text { declararem pretos, pardos ou } \\
\text { indígenas no momento da } \\
\text { inscrição terão direito ao } \\
\text { acréscimo de mais } 10 \text { pontos à } \\
\text { NPO. }\end{array}$ & $\begin{array}{l}\text { Programa de Ação } \\
\text { Afirmativa e Inclusão Social } \\
\text { - PAAIS } \\
\text { http://www.comvest.unicamp. } \\
\underline{\text { br/paais/paais.html }} \\
\text { Deliberação CONSU A12-04 } \\
\text { de } 25 / 5 / 2004 \\
\text { Resolução GR 025/2008 } \\
\text { http://www.comvest.unicamp. } \\
\text { br/vest2009/download/manual } \\
\text { 2009.pdf }\end{array}$ \\
\hline
\end{tabular}




\begin{tabular}{|c|c|c|}
\hline Estado/Universidade & Descrição das ações afirmativas & Fontes \\
\hline $\begin{array}{l}45 . \\
\text { Faculdade de } \\
\text { Medicina S.J. do Rio } \\
\text { Preto - Famerp }\end{array}$ & $\begin{array}{l}\text { Após a } 2^{\mathrm{a}} \text { fase do vestibular, } \\
\text { acréscimo de } 30 \text { pontos à Nota } \\
\text { Padronizada de Opção (NPO) } \\
\text { para candidatos que tenham } \\
\text { cursado } \\
\text { integralmente o ensino médio } \\
\text { em escolas públicas. Desses, } \\
\text { aqueles que se declararem } \\
\text { pretos, pardos ou indígenas no } \\
\text { momento da inscrição terão } \\
\text { direito ao acréscimo de mais } 10 \\
\text { pontos à NPO. }\end{array}$ & $\begin{array}{l}\text { Vestibular unificado ao da } \\
\text { UNICAMP } \\
\text { http://www.convest.unicamp. } \\
\underline{\text { br/vest2009/manual/manual.ht }} \\
\underline{\text { ml }}\end{array}$ \\
\hline $\begin{array}{l}46 . \\
\text { USP (Universidade } \\
\text { de São Paulo) }\end{array}$ & $\begin{array}{l}\text { Acréscimo de } 3 \% \text { na nota das } \\
\text { provas da } 1^{\mathrm{a}} \text { e } 2^{\mathrm{a}} \text { fases para } \\
\text { estudantes que } \\
\text { cursaram todo o Ensino Médio } \\
\text { (E. M.) em escolas públicas. } \\
\text { E.M. Público = } 3 \% \text { na nota } \\
\text { E.M. Público + ENEM = até } 9 \% \\
\text { na nota } \\
\text { E.M. Público + ENEM + } \\
\text { PASUSP = até } 12 \% \text { na nota }\end{array}$ & $\begin{array}{l}\text { http://www.fuvest.br/vest2009 } \\
\text { /manual/05-provas.pdf } \\
\text { INCLUSP -Aprovado pelo } \\
\text { Conselho Universitário } \\
\text { em } 23 \text { de maio de } 2006 . \text { Veja } \\
\text { também PASUSP. }\end{array}$ \\
\hline $\begin{array}{l}47 . \\
\text { Faculdade de } \\
\text { Tecnologia - São } \\
\text { Paulo - Fatec }\end{array}$ & $\begin{array}{l}\text { O Sistema de Pontuação } \\
\text { Acrescida concede bônus de } 3 \% \\
\text { a estudantes afrodescendentes e } \\
\text { de } 10 \% \text { a oriundos da rede } \\
\text { pública. Caso o } \\
\text { aluno esteja nas duas situações, } \\
\text { recebe } 13 \% \text { de bônus. }\end{array}$ & $\begin{array}{l}\text { Decreto Estadual } \mathrm{n}^{\circ} 49.602 / 05 \\
\text { e Deliberação CEETEPS n } \\
\text { 08, de } 02 \text { de agosto de } 2007 \\
\frac{\text { http://www.vestibularfatec.co }}{\text { m.br/vestibular/manual/portari }} \\
\text { a n331 2008.pdf }\end{array}$ \\
\hline
\end{tabular}




\begin{tabular}{|c|c|c|}
\hline Estado/Universidade & Descrição das ações afirmativas & Fontes \\
\hline $\begin{array}{l}48 . \\
\text { Centro Universitário } \\
\text { de Franca - Facef }\end{array}$ & $\begin{array}{l}.20 \% \text { das vagas para negros; } \\
.5 \% \text { das vagas para egressos da } \\
\text { escola pública; } \\
.5 \% \text { das vagas para deficientes. }\end{array}$ & $\begin{array}{l}\text { http://gemaa.iuperj.br/brasil/u } \\
\text { niversidades/Uni- } \\
\text { FACEF\%20\%E2\%80\%93\%2 } \\
\text { 0Lei\%20municipal\%20n\%C2 } \\
\text { \%BA\%206287\%20de\%20200 } \\
\underline{4 . p d f} \\
\text { Lei Ordinária: LEI No } 6.287, \\
\text { DE 10 DE NOVEMBRO DE } \\
\text { 2004. } \\
\text { Publicado na Internet por: } \\
\text { Câmara de Franca } \\
\text { http://www.facef.br/acontece/ } \\
\text { vestibular2009/assets/Manual } \\
\text { Vestibular2009.pdf }\end{array}$ \\
\hline \multicolumn{3}{|l|}{$\begin{array}{l}\text { MATO GROSSO } \\
\text { DO SUL }\end{array}$} \\
\hline $\begin{array}{l}49 . \\
\text { Universidade } \\
\text { Federal da Grande } \\
\text { Dourados - UFGD }\end{array}$ & $\begin{array}{l}25 \% \text { das vagas para egressos da } \\
\text { escola pública }\end{array}$ & $\begin{array}{l}\text { Edital PROGRAD 73/2007 } \\
\text { EDITAL PROGRAD N. 26/2008, } \\
\text { DE 06 DE NOVEMBRO DE } 2008 \\
\text { PROCESSO SELETIVO DA UFGD } \\
\text { - VERÃO 2009 } \\
\text { (PSV - 2009/UFGD) } \\
\text { http://www.ufgd.edu.br/vestib } \\
\text { ular/manualcandidato.pdf }\end{array}$ \\
\hline $\begin{array}{l}50 . \\
\text { Universidade } \\
\text { Estadual de Mato } \\
\text { Grosso do Sul - } \\
\text { UEMS }\end{array}$ & $\begin{array}{l}10 \% \text { das vagas para indígenas e } \\
20 \% \text { das vagas para negros } \\
\text { egressos do ensino médio } \\
\text { público }\end{array}$ & $\begin{array}{l}\text { Lei estadual } \mathrm{n}^{\mathrm{o}} 2.589 \text { de } 26 \text { de } \\
\text { Dezembro de } 2002 \text { e Lei } \\
\text { Estadual } \mathrm{n}^{\mathrm{o}} 2.605 \text { de } 06 \text { de } \\
\text { Janeiro de } 2003 \text {. } \\
\text { http://www.vestibular.uems.br } \\
\text { /documentos/editais/edital ne } \\
\text { gros.pdf }\end{array}$ \\
\hline
\end{tabular}




\begin{tabular}{|c|c|c|}
\hline Estado/Universidade & Descrição das ações afirmativas & Fontes \\
\hline \multicolumn{3}{|l|}{ MATO GROSSO } \\
\hline $\begin{array}{l}51 . \\
\text { Universidade do } \\
\text { Estado de Mato } \\
\text { Grosso - Unemat }\end{array}$ & $\begin{array}{l}25 \% \text { das vagas para negros que } \\
\text { tenham feito seus cursos } \\
\text { fundamental e médio } \\
\text { exclusivamente em escolas } \\
\text { públicas, ou, que comprovem } \\
\text { residência no Estado de MS há } \\
\text { pelo menos três anos, ou, que } \\
\text { tenham cursado o ensino } \\
\text { fundamental e médio em } \\
\text { estabelecimentos particulares, } \\
\text { com bolsa de estudo total ou } \\
\text { parcial. }\end{array}$ & $\begin{array}{l}\text { PIIER - Programa de } \\
\text { Integração e Inclusão Étnico- } \\
\text { Racial } \\
\text { Resolução 200/2004 } \\
\text { CONEPE anexo IV } \\
\text { http://www.unemat.br/vestibul } \\
\text { ar/downloads/vest 2009 1/do } \\
\underline{\text { cumentos/vestibular 2009 1 }} \\
\text { manual candidato.pdf }\end{array}$ \\
\hline $\begin{array}{l}52 . \\
\text { Centro Federal de } \\
\text { Educação } \\
\text { Tecnológica } \\
\text { do Mato Grosso - } \\
\text { CEFET-MT }\end{array}$ & $\begin{array}{l}50 \% \text { das vagas para alunos que } \\
\text { tenham cursado todo o Ensino } \\
\text { Médio em Escola Pública. }\end{array}$ & $\begin{array}{l}\text { SERVIÇO PÚBLICO } \\
\text { FEDERAL } \\
\text { CENTRO FEDERAL DE } \\
\text { EDUCAÇÃO } \\
\text { TECNOLÓGICA DE MATO } \\
\text { GROSSO } \\
\text { DIRETORIA DE } \\
\text { EDUCAÇÃO / } \\
\text { COORDENAÇÃO DE } \\
\text { POLÍTICAS DE INGRESSO } \\
\text { EDITAL No. 022/2008 } \\
\text { http://www.cefetmt.br/cefetmt } \\
\text { novo/page/upload/edital tecn } \\
\text { ologo \%202008 2.pdf } \\
\text { Resolução No } 013 \text {, de } 04 \text { de } \\
\text { outubro de } 2007 \text { - Conselho } \\
\text { Diretor }\end{array}$ \\
\hline $\begin{array}{l}53 . \\
\text { Universidade } \\
\text { Federal de Mato } \\
\text { Grosso - } \\
\text { UFMT }\end{array}$ & $\begin{array}{l}20 \text { vagas suplementares àquelas } \\
\text { ofertadas no Processo Seletivo } \\
\text { de } 2009 \text {, para serem disputadas } \\
\text { exclusivamente pelos povos } \\
\text { indígenas de Mato Grosso }\end{array}$ & $\begin{array}{l}\text { Resolução CONSEPE N. }{ }^{\circ} 48 \\
\text { de } 20 \text { de junho de } 2008 \text {, suas } \\
\text { alterações e a legislação } \\
\text { vigente. } \\
\text { EDITAL N. } .^{\circ} \mathbf{0 0 2 / 2 0 0 8 -} \\
\text { CEV/UFMT } \\
\text { http://www.ufmt.br/vestibular/co } \\
\text { ncursos/indigenaIV/paginas/edita } \\
\text { is/editalindigena iv.htm }\end{array}$ \\
\hline
\end{tabular}




\begin{tabular}{|c|c|c|}
\hline Estado/Universidade & Descrição das ações afirmativas & Fontes \\
\hline \multicolumn{3}{|l|}{$\begin{array}{l}\text { DISTRITO } \\
\text { FEDERAL }\end{array}$} \\
\hline $\begin{array}{l}54 . \\
\text { Universidade de } \\
\text { Brasília - UnB }\end{array}$ & $20 \%$ das vagas para negros & $\begin{array}{l}\text { Resolução CEPE 38/2003 } \\
\text { http://www.cespe.unb.br/vesti } \\
\text { bular/1VEST2009/arquivos/E } \\
\text { D 3 2008 1 VEST 2009 A } \\
\text { BT FINAL FORM.PDF }\end{array}$ \\
\hline $\begin{array}{l}55 . \\
\text { Escola Superior de } \\
\text { Ciências da Saúde - } \\
\text { ESCS-DF }\end{array}$ & $\begin{array}{l}\text { Reserva de } 40 \% \text { das vagas para } \\
\text { os alunos que comprovem ter } \\
\text { cursado integralmente os } \\
\text { ensinos fundamental e médio } \\
\text { em escolas públicas do Distrito } \\
\text { Federal. }\end{array}$ & $\begin{array}{l}\text { Lei Distrital N³.361/2004 } \\
\text { http://www.cl.df.gov.br/portal } \\
\text { legislacao/leis-distritais-1/ } \\
\text { EDITAL No 54, DE 28 DE } \\
\text { OUTUBRO DE 2008 } \\
\text { http://www.escs.edu.br/lercon } \\
\text { teudo.php?ConteudoId }=12\end{array}$ \\
\hline \multicolumn{3}{|l|}{ GOIÁS } \\
\hline $\begin{array}{l}56 . \\
\text { Universidade } \\
\text { Estadual de Goiás - } \\
\text { UEG }\end{array}$ & $\begin{array}{l}.20 \% \text { das vagas para alunos } \\
\text { oriundos de escola pública; } \\
.20 \% \text { das vagas para negros; } \\
.5 \% \text { para indígenas e portadores } \\
\text { de deficiência. }\end{array}$ & $\begin{array}{l}\text { Lei } \mathrm{N}^{\circ} 14.832 \text {, de } 12 \text { de julho } \\
\text { de } 2004 \\
\text { http://gemaa.iuperj.br/brasil/u } \\
\text { niversidades/UEG\%20- } \\
\text { \%20Lei\%2014832\%20de } \% 20 \\
\underline{\underline{2004 . p d f}} \\
\text { http://www.nucleodeselecao.u } \\
\text { eg.br/ }\end{array}$ \\
\hline $\begin{array}{l}57 . \\
\text { Fundação de Ensino } \\
\text { Superior de } \\
\text { Goiatuba FESG }\end{array}$ & $\begin{array}{l}.15 \% \text { para alunos egressos da } \\
\text { escola pública; } \\
.15 \% \text { para negros; } \\
.3 \% \text { indígenas e deficientes. }\end{array}$ & $\begin{array}{l}\text { Lei } \mathrm{N}^{\circ} 14.832 \text {, de } 12 \text { de julho } \\
\text { de } 2004 \\
\text { Manual do Candidato } 2009 \\
\text { http://fafich.org.br/index.php? } \\
\text { option=com_docman\&task=d } \\
\text { oc_download\&gid=225\&Item } \\
\text { id=139 }\end{array}$ \\
\hline
\end{tabular}




\begin{tabular}{|c|c|c|}
\hline Estado/Universidade & Descrição das ações afirmativas & Fontes \\
\hline $\begin{array}{l}58 . \\
\text { FIMES Faculdades } \\
\text { Integradas de } \\
\text { Mineiros }\end{array}$ & $\begin{array}{l}5 \% \text { das vagas para portadores } \\
\text { de deficiência física }\end{array}$ & $\begin{array}{l}\text { Edital 03/2008 } \\
\text { http://vestibular.fimes.edu.br/ } \\
\text { 2009_1/files/manualcandidato } \\
\text { 2009.pdf }\end{array}$ \\
\hline \multicolumn{3}{|l|}{ TOCANTINS } \\
\hline $\begin{array}{l}59 . \\
\text { Fundação } \\
\text { Universidade } \\
\text { Federal do } \\
\text { Tocantins - UFT }\end{array}$ & $\begin{array}{l}5 \% \text { de cada curso oferecido } \\
\text { para a etnia indígena }\end{array}$ & $\begin{array}{l}\text { Resolução 3A/2004 } \\
\text { CONSEPE } \\
\text { EDITAL N }{ }^{\circ} 044 / 2008 \text { de } 07 \\
\text { DE AGOSTO DE } 2008 \text { - } \\
\text { VESTIBULAR 2009 } \\
\text { http://www.copese.uft.edu.br/i } \\
\text { ndex.php?option=com docma } \\
\underline{\text { n\&task=doc download\&gid= }} \\
\underline{1359 \& I t e m i d=223}\end{array}$ \\
\hline \multicolumn{3}{|l|}{ AMAZONAS } \\
\hline $\begin{array}{l}60 . \\
\text { Universidade do } \\
\text { Estado do } \\
\text { Amazonas - UEA }\end{array}$ & $\begin{array}{l}80 \% \text { das vagas são para alunos } \\
\text { oriundos de escolas públicas ou } \\
\text { privadas do estado do } \\
\text { Amazonas. Destas vagas } 60 \% \\
\text { serão destinadas aos candidatos } \\
\text { oriundos do ensino médio em } \\
\text { escolas públicas do Estado do } \\
\text { Amazonas. Além de um } \\
\text { total de } 173 \text { vagas disputadas } \\
\text { exclusivamente por candidatos } \\
\text { das etnias indígenas do Estado } \\
\text { do Amazonas. }\end{array}$ & $\begin{array}{l}\frac{\text { http://www2.uea.edu.br/data/c }}{\text { ategoria/vestibular/download/ }} \\
\text { 783-1.pdf } \\
\text { art. } 5^{\circ} \text {, caput e } \S 1^{\circ} \text {, da Lei } \\
\text { Estadual } 2894 \text { de } 31 \text { de maio } \\
\text { de } \\
2004 .\end{array}$ \\
\hline \multicolumn{3}{|l|}{ PARÁ } \\
\hline $\begin{array}{l}61 . \\
\text { Universidade } \\
\text { Federal do Pará- } \\
\text { UFPA }\end{array}$ & $\begin{array}{l}50 \% \text { das vagas aos } \\
\text { estudantes que cursaram todo } \\
\text { o Ensino Médio em escola } \\
\text { pública. Dessas, } 40 \% \text { se } \\
\text { destinam aos candidatos negros. }\end{array}$ & $\begin{array}{l}\text { Resolução } \mathrm{n}^{\circ} 3361 \text { de } 5 \text { de } \\
\text { agosto de } 2005 \text { do Conselho } \\
\text { Superior de Ensino Pesquisa e } \\
\text { Extensão (CONSEPE) } \\
\text { http://www.ceps.ufpa.br/daves } \\
\text { lPSS2009/EDITAL_PSS 200 } \\
\text { V_VERSAO FINAL.pdf }\end{array}$ \\
\hline
\end{tabular}




\begin{tabular}{|c|c|c|}
\hline Estado/Universidade & Descrição das ações afirmativas & Fontes \\
\hline $\begin{array}{l}62 . \\
\text { Universidade } \\
\text { Federal Rural da } \\
\text { Amazônia - UFRA }\end{array}$ & $\begin{array}{l}\text { Reserva de vagas aos } \\
\text { candidatos oriundos de escolas } \\
\text { públicas. O número de vagas } \\
\text { será diretamente proporcional } \\
\text { ao número de candidatos } \\
\text { oriundos de escolas públicas } \\
\text { inscritos no processo seletivo. }\end{array}$ & $\begin{array}{l}\text { Art. } 95 \text { do Regimento da } \\
\text { UFRA. } \\
\text { (interno) } \\
\text { http://www.ufra.edu.br/webve } \\
\text { st/edital2008/edital_vest_2008 } \\
\text {.pdf }\end{array}$ \\
\hline \multicolumn{3}{|l|}{ BAHIA } \\
\hline $\begin{array}{l}63 . \\
\text { Universidade } \\
\text { Federal da Bahia - } \\
\text { UFBA }\end{array}$ & $\begin{array}{l}.36,55 \% \text { das vagas para } \\
\text { candidatos de escola pública } \\
\text { que se declarem pretos ou } \\
\text { pardos } \\
.6,45 \% \text { das vagas para } \\
\text { candidatos de escola pública } \\
.2 \% \text { das vagas para candidatos } \\
\text { de escola pública índio- } \\
\text { descendente } \\
\text {.até } 2 \text { vagas extras por curso, } \\
\text { para índios aldeados ou } \\
\text { moradores das comunidades } \\
\text { remanescentes dos quilombos, } \\
\text { oriundos do ensino público. }\end{array}$ & $\begin{array}{l}\text { Resolução Consepe } \\
\text { n}^{\circ} 01 / 04 \text { de } 2004 \\
\text { http://www.vestibular.ufba.br/ } \\
\text { http://www.vestibular.ufba.br/ } \\
\text { cotas/Cotas.htm }\end{array}$ \\
\hline $\begin{array}{l}64 . \\
\text { Universidade } \\
\text { Federal do } \\
\text { Recôncavo da Bahia } \\
\text { - UFRB }\end{array}$ & $\begin{array}{l}.43 \% \text { das vagas para egressos de } \\
\text { escola pública, dessas, } 85 \% \\
\text { para pretos ou pardos; } \\
.2 \% \text { das vagas para candidatos } \\
\text { oriundos de escola pública } \\
\text { índio-descendentes; } \\
\text {. até } 2 \text { vagas extras por curso, } \\
\text { para índios aldeados ou } \\
\text { moradores das comunidades } \\
\text { remanescentes dos quilombos, } \\
\text { oriundos do ensino público. }\end{array}$ & $\begin{array}{l}\text { Vestibular unificado com a } \\
\text { UFBA } \\
\text { RESOLUÇÃO No 014/2008 } \\
\underline{\text { http://www.ufrb.edu.br/vestib }} \\
\underline{\text { ular/ }} \\
\text { http://www.vestibular.ufba.br/ } \\
\text { cotas/Cotas.htm }\end{array}$ \\
\hline $\begin{array}{l}65 . \\
\text { Universidade do } \\
\text { Estado da Bahia-- } \\
\text { UNEB }\end{array}$ & $\begin{array}{l}.40 \% \text { das vagas para candidatos } \\
\text { negros, oriundos de escola } \\
\text { pública e com renda familiar } \\
\text { mensal inferior a } 10 \text { Salários } \\
\text { Mínimos } \\
.5 \% \text { das vagas para candidatos } \\
\text { indígenas oriundos de escola } \\
\text { pública e com renda familiar } \\
\text { mensal inferior a } 10 \text { Salários } \\
\text { Mínimos. }\end{array}$ & $\begin{array}{l}\text { Resolução no } 605 / 2008 \text { do } \\
\text { CONSU } \\
\text { http://vestibular.uneb.br/anexo } \\
\text { s/edital_2009.pdf }\end{array}$ \\
\hline
\end{tabular}




\begin{tabular}{|c|c|c|}
\hline Estado/Universidade & Descrição das ações afirmativas & Fontes \\
\hline $\begin{array}{l}66 . \\
\text { Universidade } \\
\text { Estadual de Santa } \\
\text { Cruz -UESC }\end{array}$ & $\begin{array}{l}.50 \% \text { das vagas para candidatos } \\
\text { oriundos de escolas públicas, } \\
\text { sendo que, deste percentual, } \\
75 \% \text { serão destinadas aos } \\
\text { negros; } \\
.2 \text { vagas extras por curso para } \\
\text { indígenas aldeados ou } \\
\text { moradores remanescentes dos } \\
\text { quilombos, oriundos de escola } \\
\text { pública. }\end{array}$ & 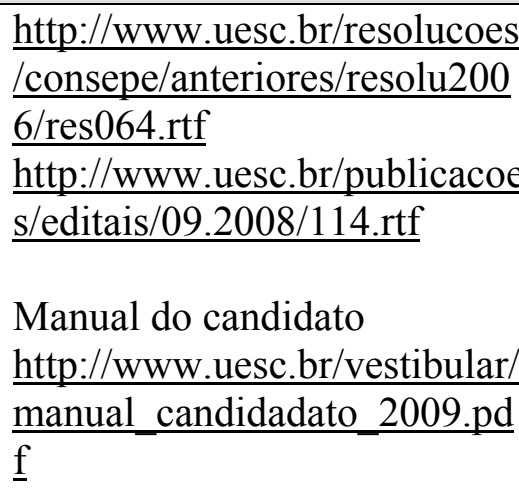 \\
\hline $\begin{array}{l}67 . \\
\text { Universidade } \\
\text { Estadual de Feira de } \\
\text { Santana -UEFS }\end{array}$ & $\begin{array}{l}.50 \% \text { das vagas para candidatos } \\
\text { oriundos da rede pública, } \\
\text { destas, } 80 \% \text { para negros; } \\
.2 \text { vagas a mais por curso para } \\
\text { indígenas e quilombolas, } \\
\text { prioritariamente oriundos de } \\
\text { escolas públicas }\end{array}$ & $\begin{array}{l}\text { Resolução do } \\
\text { CONSU 034/2006 } \\
\text { http://prosel.uefs.br/pdf/resolu } \\
\text { cao_consu_34_2006.pdf }\end{array}$ \\
\hline $\begin{array}{l}68 . \\
\text { Centro Federal de } \\
\text { Educação } \\
\text { Tecnológica da } \\
\text { Bahia - CEFET-BA }\end{array}$ & $\begin{array}{l}50 \% \text { das vagas para estudantes } \\
\text { oriundos de Escola Pública, } \\
\text { sendo que, dessas, } 60 \% \text { das } \\
\text { vagas para estudantes que se } \\
\text { declarem afrodescendentes, e } \\
5 \% \text { das vagas para estudantes } \\
\text { que se declarem índios ou índio- } \\
\text { descendentes. }\end{array}$ & $\begin{array}{l}\text { RESOLUÇÃO No } 10 \text { DE } 1^{\circ} \\
\text { DE JUNHO DE } 2006 \\
\text { http://www.cefetba.br/informa } \\
\text { tivo/resolucoes/RE 10- } \\
\text { 2006_Sobre_COTAS.pdf } \\
\text { http://sistemas.cefetba.br/scrip } \\
\text { ts/selecao/2009/superior/edital } \\
\text {.pdf }\end{array}$ \\
\hline
\end{tabular}




\begin{tabular}{|c|c|c|}
\hline Estado/Universidade & Descrição das ações afirmativas & Fontes \\
\hline \multicolumn{3}{|l|}{ ALAGOAS } \\
\hline $\begin{array}{l}69 . \\
\text { Universidade } \\
\text { Federal de Alagoas - } \\
\text { UFAL }\end{array}$ & $\begin{array}{l}20 \% \text { das vagas totais são } \\
\text { reservadas para a população } \\
\text { afrodescendente } \\
\text { oriunda exclusiva e } \\
\text { integralmente } \\
\text { de escolas de ensino médio } \\
\text { públicas. O percentual acima } \\
\text { definido será distribuído da } \\
\text { seguinte forma: } \\
.60 \% \text { (sessenta por cento) para } \\
\text { as mulheres negras e } \\
40 \% \text { (quarenta por cento) para } \\
\text { os homens negros. } \\
\text { Os candidatos inscritos nos } \\
\text { cursos de graduação para o } \\
\text { Campus Arapiraca e que } \\
\text { cursaram integral } \\
\text { e exclusivamente o ensino } \\
\text { médio em escolas localizadas } \\
\text { no interior do Estado de } \\
\text { Alagoas, terão sua média final } \\
\text { acrescida em } 10 \% \text {. }\end{array}$ & $\begin{array}{l}\text { Resoluções No } 01 / 2007- \\
\text { CONSUNI/UFAL, de } 15 \text { de } \\
\text { janeiro de } 2007 \text { e N }{ }^{\circ} 05 / 2007- \\
\text { CONSUNI/UFAL, de } \\
05 \text { de março de } 2007 \\
\text { http://www.copeve.ufal.br/sist } \\
\underline{\text { ema/pss/Processo\%20Seletivo }} \\
\underline{\text { \%20Seriado\%20Unificado\%2 }} \\
\underline{\text { 02009/Edital.pdf }}\end{array}$ \\
\hline \multicolumn{3}{|l|}{ PIAUÍ } \\
\hline $\begin{array}{l}70 . \\
\text { Universidade } \\
\text { Federal do } \\
\text { Piauí - UFPI }\end{array}$ & $\begin{array}{l}20 \% \text { das vagas oferecidas serão } \\
\text { reservadas aos candidatos que } \\
\text { tiverem feito a Educação Básica } \\
\text { (Ensino Fundamental e Ensino } \\
\text { Médio) integralmente em escola } \\
\text { pública }\end{array}$ & $\begin{array}{l}\text { PSIU - Programa Seriado de } \\
\text { Ingresso na Universidade } \\
\underline{\text { http://www.ufpi.br/copeve/do }} \\
\frac{\text { wnloads/psiu2008/editais/gera }}{\underline{\text { l.pdf }}} \\
\text { Edital No } 28 / 2008 \text { - UFPI }\end{array}$ \\
\hline
\end{tabular}




\begin{tabular}{|c|c|c|}
\hline Estado/Universidade & Descrição das ações afirmativas & Fontes \\
\hline \multicolumn{3}{|l|}{ MARANHÃO } \\
\hline $\begin{array}{l}71 . \\
\text { Universidade } \\
\text { Federal do } \\
\text { Maranhão - UFMA }\end{array}$ & $\begin{array}{l}.25 \% \text { das vagas destinadas } \\
\text { para estudantes oriundos das } \\
\text { escolas públicas e } 25 \% \text { das } \\
\text { vagas para negros oriundos da } \\
\text { escola pública. } \\
\text {.Quatro vagas adicionais: duas } \\
\text { para índio e duas para } \\
\text { deficiente, por curso e por } \\
\text { semestre letivo }\end{array}$ & $\begin{array}{l}\text { Resoluções } 568 \text { e } \\
569 \text { - CONSEPE, de } \\
24 \text { de outubro de } \\
\text { 2007, as Resoluções } \\
48 / 2005 \text { e } 69 / 2006 \text { - } \\
\text { CONSAD } \\
\text { http://www.ufma.br/editais/ar } \\
\text { quivos/edital proen psv 200 } \\
\text { 9.pdf } \\
\text { EDITAL No. 95/2008 - } \\
\text { PROEN }\end{array}$ \\
\hline \multicolumn{3}{|l|}{ PERNAMBUCO } \\
\hline $\begin{array}{l}72 . \\
\text { Universidade de } \\
\text { Pernambuco - UPE }\end{array}$ & $\begin{array}{l}20 \% \text { (vinte por cento) das vagas } \\
\text { para candidatos aprovados que } \\
\text { tiverem cursado o ensino médio, } \\
\text { integralmente, em regime } \\
\text { regular e exclusivamente, em } \\
\text { escolas da rede pública estadual } \\
\text { ou municipal do Estado de } \\
\text { Pernambuco. }\end{array}$ & $\begin{array}{l}\frac{\text { http://www.upenet.com.br/con }}{\text { cursos/vestibular2009/arquivo }} \\
\frac{\text { s/MANUAL\%20DO\%20VES }}{\text { T\%202009\%202906.pdf }} \\
\text { Resolução CONSUN } \\
\text { No 10/2004, alterada }_{\text {pela Resolução N }} \\
\text { 004/ } 2007\end{array}$ \\
\hline $\begin{array}{l}73 . \\
\text { Universidade } \\
\text { Federal de } \\
\text { Pernambuco - UFPE }\end{array}$ & $\begin{array}{l}\text { a) Os candidatos às vagas na Unidade } \\
\text { Acadêmica da UFPE no Recife que } \\
\text { concluíram, ou que vierem a concluir, } \\
\text { integral e exclusivamente, } \\
\text { em regime regular, os três anos } \\
\text { do Ensino Médio em qualquer escola } \\
\text { pública estadual ou municipal do } \\
\text { estado de Pernambuco estarão } \\
\text { habilitados a receber incremento de } \\
10 \% \text { em seu argumento de } \\
\text { classificação. } \\
\text { b) Os candidatos que concorrem a } \\
\text { uma vaga nas Unidades Acadêmicas } \\
\text { de Vitória de Santo Antão ou do } \\
\text { Agreste (Caruaru) estarão habilitados } \\
\text { a receber o incremento de } 10 \% \text { em } \\
\text { seus argumentos de classificação } \\
\text { desde que concluam, ou venham a } \\
\text { concluir, integral e exclusivamente, } \\
\text { em regime regular, os três } \\
\text { anos do Ensino Médio em qualquer } \\
\text { escola pública (estadual ou municipal) } \\
\text { ou particular do estado de Pernambuco } \\
\text { fora da cidade do Recife e da sua } \\
\text { Região Metropolitana. }\end{array}$ & $\begin{array}{l}\text { VESTIBULAR } \\
\text { UNIFICADO UFPE/ } \\
\text { UFRPE/ UNIVASF } \\
\underline{\text { http://www.covest.com.br/ }} \\
\underline{\text { http://www.pbt.com.br/manua }} \\
\underline{\underline{\text { 1/manual_candidato_vest_200 }}} \\
\underline{9 . p d f}\end{array}$ \\
\hline
\end{tabular}




\begin{tabular}{|c|c|c|}
\hline Estado/Universidade & Descrição das ações afirmativas & Fontes \\
\hline $\begin{array}{l}74 . \\
\text { CEFET Pernambuco }\end{array}$ & $\begin{array}{l}50 \% \text { das vagas para alunos } \\
\text { oriundos de escolas da Rede } \\
\text { Pública Estadual ou Municipal. }\end{array}$ & $\begin{array}{l}\text { Resolução no } 39 / 2007- \\
\text { CONDIR - de } 21 \text { de } \\
\text { novembro de } 2007 \\
\text { http://www.cefetpe.br/cefetpe. } \\
\text { br/novosite/vest/vest2008/cota } \\
\text { s.htm }\end{array}$ \\
\hline \multicolumn{3}{|l|}{$\begin{array}{l}\text { RIO GRANDE DO } \\
\text { NORTE }\end{array}$} \\
\hline $\begin{array}{l}75 . \\
\text { Universidade do } \\
\text { Estado do Rio } \\
\text { Grande do Norte- } \\
\text { UERN }\end{array}$ & $\begin{array}{l}50 \% \text { das vagas são destinadas } \\
\text { para alunos que tenham cursado } \\
\text { integralmente o Ensino } \\
\text { Fundamental e Médio em } \\
\text { Escola Pública. }\end{array}$ & $\begin{array}{l}\text { Lei Estadual } n^{\circ} 8.258 \text {, de } 27 \\
\text { de dezembro de } 2002 \\
\text { http://www.uern.br/fnc/edital } \\
\text { funcoes.asp?Comando=getEdi } \\
\text { tal\&edt id=111 }\end{array}$ \\
\hline $\begin{array}{l}76 . \\
\text { Instituto de } \\
\text { Educação Superior } \\
\text { Presidente Kennedy }\end{array}$ & $\begin{array}{l}50 \% \text { das vagas são destinadas } \\
\text { para alunos que tenham cursado } \\
\text { integralmente o Ensino } \\
\text { Fundamental e Médio em } \\
\text { Escola Pública. }\end{array}$ & $\begin{array}{l}\text { Lei Estadual } n^{\circ} 8.258 \text {, de } 27 \\
\text { de dezembro de } 2002 \\
\underline{\text { http://www.ifesp.rn.gov.br/ind }} \\
\underline{\text { ex.asp }}\end{array}$ \\
\hline $\begin{array}{l}77 . \\
\text { Centro Federal de } \\
\text { Educação } \\
\text { Tecnológica do Rio } \\
\text { Grande do Norte - } \\
\text { CEFET-RN: }\end{array}$ & $\begin{array}{l}\text { Cursos superiores de graduação } \\
\text { tecnológica e licenciaturas: } \\
50 \% \text { para os alunos que } \\
\text { cursaram do } 6^{\circ} \text { ao } 9^{\circ} \text { ano do } \\
\text { Ensino Fundamental e todo o } \\
\text { Ensino Médio em escolas da } \\
\text { rede pública }\end{array}$ & $\begin{array}{l}\text { Resolução 4/2005 do } \\
\text { Conselho Diretor } \\
\text { http://www.cefetrn.br/exames/ } \\
\text { exame-vestibular- } \\
\underline{2009 / \text { edital 10 2008 sub- }} \\
\text { vest-ead.pdf/download }\end{array}$ \\
\hline $\begin{array}{l}78 . \\
\text { Universidade } \\
\text { Federal do Rio } \\
\text { Grande do Norte - } \\
\text { UFRN }\end{array}$ & $\begin{array}{l}\text { Bônus para escola pública, } \\
\text { pontos fixos sobre nota do } \\
\text { aluno, com base no desempenho } \\
\text { dos alunos da rede pública } \\
\text { inscritos. }\end{array}$ & $\begin{array}{l}\text { http://www.comperve.ufrn.br/ } \\
\text { conteudo/psanteriores/ps2009/ } \\
\text { documentos/EditalVestibular2 } \\
\text { 009.pdf }\end{array}$ \\
\hline
\end{tabular}




\begin{tabular}{|c|c|c|}
\hline Estado/Universidade & Descrição das ações afirmativas & Fontes \\
\hline \multicolumn{3}{|l|}{ PARAÍBA } \\
\hline $\begin{array}{l}79 . \\
\text { Universidade } \\
\text { Estadual da } \\
\text { Paraíba -UEPB }\end{array}$ & $\begin{array}{l}30 \% \text { das vagas para candidatos } \\
\text { que que tenham cursado as três } \\
\text { séries do ensino médio em } \\
\text { Escola Pública do Estado da } \\
\text { Paraíba. }\end{array}$ & $\begin{array}{l}\text { MANUAL DO CANDIDATO } \\
\underline{\text { http://www.uepbcomvest.inf.b }} \\
\underline{\text { r/concursos/vestibulares/vest2 }}\end{array}$ \\
\hline \multicolumn{3}{|l|}{ CEARÁ } \\
\hline $\begin{array}{l}80 . \\
\text { Universidade } \\
\text { Estadual Vale do } \\
\text { Acaraú - UVA }\end{array}$ & $\begin{array}{l}5 \% \text { portadores de necessidades } \\
\text { especiais }\end{array}$ & $\begin{array}{l}\text { EDITAL No 40/2008 } \\
\text { http://www.uvanet.br/ceps/ma } \\
\underline{\text { terial/edital_091.pdf }}\end{array}$ \\
\hline \multicolumn{3}{|l|}{ SERGIPE } \\
\hline $\begin{array}{l}81 . \\
\text { Universidade } \\
\text { Federal de Sergipe - } \\
\text { UFS }\end{array}$ & $\begin{array}{l}50 \% \text { escola pública, dessas } \\
\text { vagas } 70 \% \text { para autodeclarados } \\
\text { negros ou indígenas, mais uma } \\
\text { vaga por curso para portadores } \\
\text { de deficiências }\end{array}$ & $\begin{array}{l}\text { http://www.ufs.br/?pg=noticia } \\
\underline{\text { \&id=1611 }} \\
\text { OBS: válido para ingresso em } \\
\text { 2010, em exame a ser } \\
\text { realizado em } 2009\end{array}$ \\
\hline
\end{tabular}

\subsection{Comentários sobre as ações afirmativas nas Instituições Públicas de Ensino Superior - IPES}

Baseados na tabela 3 "Relação das ações afirmativas nas Instituições Públicas de Ensino Superior - 2008", observamos que das oitenta e uma instituições pesquisadas, setenta e três utilizam como ação afirmativa a modalidade "cotas", sete utilizam a modalidade "bônus" e uma utiliza as duas modalidades, "cotas" e "bônus" (Universidade Federal de Alagoas).

Analisemos a modalidade cotas. As IPES adotam substancialmente o critério de o aluno ser oriundo de escola pública para a utilização dessa modalidade. Consideramos setenta e quatro IPES oferecendo cotas, dessas, cinqüenta e nove $(79,72 \%)$ estabelecem em algum dos seus critérios que o candidato seja oriundo de escola pública. Os alunos "oriundos de escola 
pública" são aqueles que fizeram pelo menos o ensino médio em escolas públicas. Algumas IPES exigem mais anos de escolaridade em escola pública, chegando a exigir todo ensino fundamental.

Os critérios das IPES mostram combinações. Para facilitar a compreensão das diversas combinações, foi criada a tabela 4 "Critérios para as cotas e número de IPES que aplicam os critérios":

Tabela 4 - Critérios para as cotas e número de IPES que aplicam os critérios

\begin{tabular}{|c|c|}
\hline $\begin{array}{c}\text { Critérios para as cotas. É necessário e } \\
\text { suficiente que o candidato seja: }\end{array}$ & $\begin{array}{c}\mathbf{N}^{\mathbf{0}} \text { de IPES que aplicam } \\
\text { os critérios }\end{array}$ \\
\hline Negro & 6 \\
\hline Deficiente físico & 13 \\
\hline Indígena ou índio-descendente & 24 \\
\hline Oriundo de escola pública e quilombola & 4 \\
\hline Oriundo de escola pública & 38 \\
\hline Oriundo de escola pública e negro & 20 \\
\hline Oriundo de escola pública e indígena & 9 \\
\hline Hipossuficiente & 1 \\
\hline Hipossuficiente e negro & 14 \\
\hline Hipossuficiente e indígena & 12 \\
\hline Hipossuficiente e deficiente físico & 16 \\
\hline Hipossuficiente e oriundo de escola pública & 1 \\
\hline $\begin{array}{c}\text { Hipossuficiente oriundo de escola pública e } \\
\text { negro }\end{array}$ & 1 \\
\hline $\begin{array}{c}\text { Hipossuficiente oriundo de escola pública e } \\
\text { indígena }\end{array}$ & 12 \\
\hline $\begin{array}{c}\text { Hipossuficiente, oriundo de escola pública, filho de } \\
\text { policiais civis, militares, bombeiros militares e de inspetores de } \\
\text { segurança e administração penitenciária, mortos em razão do } \\
\text { serviço. }\end{array}$ & \\
\hline
\end{tabular}

Candidatos hipossuficientes são aqueles dos quais é exigida a apresentação de uma renda per capita máxima ou renda familiar máxima conforme critério das IPES. As menores rendas máximas são exigidas pela Universidade Estadual do Rio Grande do Sul - UERGS, pela Universidade Estadual de Montes Claros - UNIMONTES e pela Universidade do Estado de Minas Gerais - UEMG, onde a renda per capita familiar não pode ultrapassar um salário 
mínimo. A utilização do critério "hipossuficiência" representa a busca por justiça social focando os grupos mais desfavorecidos economicamente.

Seis IPES utilizam o critério "negro" para as cotas; quatro IPES utilizam os critérios "oriundo de escola pública e quilombola"; vinte IPES utilizam os critérios "oriundo de escola pública e negro"; quatorze IPES utilizam os critérios "hipossuficiente e negro"; finalmente, quanto aos critérios "hipossuficiente oriundo de escola pública e negro", temos uma IPES. Logo, das setenta e quatro IPES que oferecem cotas, temos quarenta e cinco $(60,81 \%)$ IPES com cotas voltadas para a população negra.

Passemos a analisar a modalidade bônus. Das IPES pesquisadas, as seguintes oferecem bônus:

1. UFF - Universidade Federal Fluminense (Rio de Janeiro)

2. Unicamp - Universidade Estadual de Campinas (São Paulo)

3. Famerp - Faculdade de Medicina S. J. do Rio Preto (São Paulo)

4. USP - Universidade de São Paulo (São Paulo)

5. Fatec - Faculdade de Tecnologia (São Paulo)

6. UFAL - Universidade Federal de Alagoas (Alagoas)

7. UFPE - Universidade Federal de Pernambuco (Pernambuco)

8. UFRN - Universidade Federal do Rio Grande do Norte (Rio Grande do Norte)

Das oito IPES que oferecem bônus, todas dão bônus para oriundos da escola pública, com exceção da UFAL, que dirige seu bônus para candidatos que estudaram em escolas do interior de Alagoas. Apenas três dão bônus para candidatos negros: a Unicamp, que dá bônus de 30 pontos à NPO (Nota Padronizada de Opção) aos oriundos de escola pública e mais 10 pontos se o aluno oriundo de escola pública se autodeclarar negro; a mesma coisa faz a Famerp; a Fatec, apresenta o Sistema de Pontuação Acrescida, concedendo bônus de 3\% a estudantes negros e $10 \%$ a oriundos de escola pública, podendo o candidato se for oriundo de escola pública e negro, obter $13 \%$ de bônus. Logo, das oito IPES pesquisadas que oferecem bônus, temos 37,5\% que dirigem sua ação afirmativa à população negra. 
Há algumas peculiaridades nas ações afirmativas das IPES. A UFAL - Universidade Federal do Alagoas, oferece $20 \%$ das suas vagas à população negra, mas dá preferência à mulher negra: desses $20 \%$ do total de vagas, $60 \%$ destinam-se às mulheres negras, e $40 \%$ destinam-se aos homens negros.

Algumas IPES dão preferência aos egressos de escolas da localidade da IPES. Por exemplo, a UEA - Universidade do Amazonas - fornece $80 \%$ das vagas para alunos oriundos de escolas públicas ou privadas do Estado do -_Amazonas (fornece 173 vagas para etnias indígenas do Estado do Amazonas, não tem cotas específicas para negros); a UPE (Universidade de Pernambuco) fornece $20 \%$ de suas vagas para oriundos do ensino médio estadual ou municipal exclusivamente do Estado de Pernambuco; e a UEPB (Universidade Estadual de Paraíba) fornece $30 \%$ das vagas para candidatos que tenham cursado o ensino médio em escola pública do Estado de Paraíba. 


\section{Conclusões}

Os dados acima analisados permitem afirmar que a população negra brasileira sofre discriminações que engendram desigualdades e conseqüentemente se constituem em violação dos direitos humanos: o direito à igualdade humana e o direito à diferença identitária, individual e coletivamente.

Não se combate as desigualdades sociais, sejam elas de classes sociais, de gênero, de raças ou etnias apenas com a retórica e as leis, que embora imprescindíveis, não são suficientes. Daí a necessidade de políticas públicas não apenas macro-sociais ou universalistas, mas também específicas ou focadas. Nestas últimas se enquadram as políticas de ação afirmativa cujas polêmicas dividem a sociedade brasileira.

As condições históricas vivenciadas pela população negra ajudam a explicar sua situação atual de grupo desfavorecido. A escravidão foi uma situação deplorável e revoltante, justificada por uma ideologia de inferioridade e desumanização dos negros, bases do racismo, o qual se verifica até os dias de hoje.

A Lei Áurea, de 13 de maio de 1988, aboliu a escravidão, instituiu a igualdade formal, mas não inseriu os negros como cidadãos iguais, pois a população negra continuou sofrendo discriminação e racismo, além da ausência de qualquer política pública para a inserção econômica dos ex-escravizados na sociedade, enquanto políticas públicas favoráveis à imigração foram feitas. $\mathrm{O}$ quadro de desigualdade racial continua até hoje, o que explica a abolição ser chamada de "abolição inconclusa".

Em fins do século XIX até a década de 30 do século XX, predominou a ideologia do branqueamento, segundo a qual a população brasileira deveria "embranquecer", para melhorar a "raça". Na década de 30, com as idéias de identidade nacional e a análise de Gilberto Freyre, segundo a qual o Brasil seria um país mestiço, e por isso peculiar nas relações raciais, sendo essas mais harmoniosas, floresce a ideologia da democracia racial. Contestada pela Frente Negra, depois pelos estudos da Unesco na década de 50 do século $\mathrm{XX}$, seu corolário 
permanece vivo até hoje, servindo como uma ideologia que permite diminuir, ou mesmo ignorar os efeitos do racismo.

Além das perdas acumuladas historicamente, estudos estatísticos mostram que a desigualdade racial é um efeito contínuo, conforme pesquisas de Carlos Hasenbalg em 1978 e as estatísticas atuais, onde se observa pelos dados do IPEA, que 25 milhões de brasileiros vivem abaixo da linha da pobreza, desses, 70\% são negros, sendo que os negros compõem $45 \%$ da população.

Podemos concluir, com base nas estatísticas, que as políticas públicas universalistas não se mostraram eficazes e eficientes para reduzir ou eliminar as desigualdades raciais. As ações afirmativas se justificam como um eficiente instrumento para complementar as políticas públicas universalistas, colaborando para identificar as metas e o público-alvo dos programas orçamentários do governo. Além disso, são de resultado visível rápido, por exemplo, no caso das cotas para os candidatos negros no ensino superior, em 4 ou 5 anos já se forma uma turma, que entrará no mercado de trabalho, e melhorará sua renda.

As desigualdades raciais justificam a adoção de ações afirmativas para a população negra. As ações afirmativas são políticas que visam compensação e mais eqüidade nas oportunidades, focando dessa maneira, os mais desfavorecidos. Há várias modalidades de ação afirmativa, e embora a modalidade cotas seja a mais conhecida, outras modalidades como bônus, bolsas, cursinhos estão sendo praticadas em favor da população negra.

Desde 2001, após antecedentes e preparativos para a III Conferência Mundial de Combate ao Racismo, Discriminação Racial, Xenofobia e Intolerância Correlata, em Durban, ações afirmativas para a população negra ocorreram em vários âmbitos. Universidades Públicas Federais, Estaduais e Municipais passaram a oferecer cotas e bônus para a população negra na disputa por suas vagas; foi sancionada a lei 10.639/2003, que obriga a inclusão da temática "História e Cultura Afro-Brasileira" no currículo da rede oficial de ensino; foi feito o decreto $n^{\circ} 4.887 / 2003$, que regulamenta o procedimento para identificação, reconhecimento, delimitação, demarcação e titulação das terras ocupadas por remanescentes das comunidades dos quilombos; foi criado em 2005 o PROUNI, Programa Universidade para todos, que prevê 
cotas para a população negra na aquisição de bolsas para estudos em escolas particulares, e outros exemplos de ações afirmativas.

Os defensores das cotas nas Instituições Públicas de Ensino Superior dizem que as cotas são constitucionais, pois além da Constituição buscar a igualdade material, o artigo 206 da Constituição diz: “O ensino será ministrado com base nos seguintes princípios: I. igualdade de acesso e permanência na escola”. Sendo a sociedade desigual economicamente, os que são melhor aquinhoados têm uma educação de melhor qualidade. Logo, para garantir a igualdade de acesso à escola, é necessário medidas compensatórias para os mais pobres. Como entre os mais pobres estão os negros, é justo que haja cotas para eles. As cotas não atentam contra a meritocracia pois, na competição do vestibular as pessoas não saem do mesmo ponto de partida. É justo que os que estejam em desvantagem recebam compensação. Nesse sentido acredito que as cotas raciais combinadas com critérios econômicos sejam mais justas, pois têm mais acurácia com o grupo mais desfavorecido: os negros pobres. As cotas não diminuem a excelência da universidade, como alegam alguns, pois os estudantes cotistas passam pelos mesmos cursos e sistemas de avaliação. Além disso, estudos de universidades que adotaram cotas mostraram que os cotistas têm resultados equivalentes aos dos não-cotistas. As cotas não têm poder de criar o racismo ou acirrar o ódio racial, pois o racismo já existe, é uma realidade na sociedade brasileira. Porém, é justo que a população negra construa sua identidade e a partir desta identidade lute por seus direitos. Por fim, as cotas não devem ser humilhantes para os negros, pois representam uma conquista de sua luta por uma vida mais digna e é justo que os negros usufruam os frutos de sua luta. Os argumentos favoráveis às cotas se dirigem à justiça social, pois baseiam-se na busca de eqüidade social e melhoria nas oportunidades de um grupo em desvantagem social: a população negra.

O filósofo John Rawls traz contribuições ao analisar a justiça social como objeto da estrutura básica da sociedade, tendo a justiça social, como princípio, entre outros, o de buscar melhorar a situação dos menos favorecidos. Nesse contexto as ações afirmativas se inserem.

A Constituição de 1988 adotou a Justiça Social como ditame e objetivo do Estado, conforme artigos 170 e 193, referentes à ordem econômica e social respectivamente. 
Combatendo as desigualdades, as ações afirmativas para a população negra tornam-se um importante instrumento para a justiça social, constituindo um meio para se atingir tal objetivo.

Foram analisadas ações afirmativas em oitenta e uma Instituições Públicas de Ensino Superior (IPES). Setenta e três utilizam a modalidade "cotas", sete utilizam a modalidade "bônus" e uma utiliza as duas modalidades, "cotas" e "bônus" (Universidade Federal de Alagoas). Das que oferecem cotas, quarenta e cinco $(60,81 \%)$ IPES têm cotas para a população negra. Das que oferecem bônus, três $(37,5 \%)$ dirigem sua ação afirmativa à população negra. Na maior parte das vezes, o critério racial é combinado com critérios sócioeconômicos. Os percentuais para candidatos negros indicam o reconhecimento dos legisladores e gestores públicos das condições desfavoráveis dessa população, e exemplificam a utilização de ações afirmativas para a população negra como instrumento de justiça social.

Em 10-12-2008 foi sancionada a Lei $\mathrm{n}^{\mathrm{o}}$ 3.594, no Estado de Mato Grosso do Sul, que reserva $10 \%$ das vagas de concursos públicos no Estado para indivíduos negros. É o primeiro Estado brasileiro a sancionar cotas no serviço público para negros. A freqüência com que ações afirmativas para a população negra vêm ocorrendo nos últimos anos, conquista de muitas lutas, traz um quadro animador para aqueles que esperam mais justiça social no Brasil. Mas muito há para ser feito, sobretudo nas áreas do imaginário social, onde o racismo e discriminação continuam inferiorizando a população negra. 


\section{BIBLIOGRAFIA}

ANDREWS, George Reid. "Democracia racial brasileira 1900-1990: um contraponto americano". Estudos Avançados. No 30 (11), maio/agosto 1997.

ANDREWS, George Reid. Negros e brancos em São Paulo (1888 - 1988). Bauru: EDUSC, 1998.

AQUINO, São Tomás de. Suma teológica. $2^{\mathrm{a}}$ parte da $2^{\mathrm{a}}$ parte. Porto Alegre: Escola Superior de Teologia São Lourenço de Brindes e Livraria Sulina, 1980.

ARISTÓTELES. Ética a Nicômaco. São Paulo: Edipro, 2002.

AZEVEDO, Célia Maria Marinho. Anti-racismo e seus paradoxos - reflexões sobre cota racial, raça e racismo. São Paulo: Annablume, 2004.

BASTIDE, Roger \& FERNANDES, Florestan. Relações Raciais entre negros e brancos em São Paulo. São Paulo: Anhembi, 1955.

BASTOS, Celso Ribeiro, MARTINS, Ives Gandra. Comentários à Constituição do Brasil. São Paulo: Saraiva, 1990, $7^{\circ}$ volume.

Bellintani, Leila Pinheiro. Ação Afirmativa e os Princípios do Direito. Rio de Janeiro: Lúmen Júris, 2006.

BENEVIDES, Maria Victória. "Cidadania e direitos humanos". Cadernos de Pesquisa São Paulo, n.104, p. 39-46, jul.1998.

BOBBIO, Norberto. A era dos direitos. Rio de Janeiro: Campus: Elsevier, 2004.

BOBBIO, Norberto. Igualdade e Liberdade. Rio de Janeiro: Ediouro, 1997.

CARDOSO, Fernando Henrique, IANNI, Octavio. Cor e mobilidade social em Florianópolis. São Paulo: Companhia Editora Nacional, 1960.

CARVALHO, José Jorge de. Inclusão Étnica e Racial no Brasil - a questão das cotas no ensino superior. São Paulo: Attar, 2006

CARVALHO, José Jorge de. "Ações afirmativas para negros e índios no ensino superior: as propostas dos NEABs". Universidade e Sociedade, Brasília, v.12, n. 29, p. 6167, mar. 2003.

CONCEIÇÃO, Fernando. Mídia e etnicidades no Brasil e nos Estados Unidos. São Paulo: Livro Pronto, 2005. 
COMPARATO, Fábio Konder. Ética: Direito moral e religião no mundo moderno. São Paulo: Companhia das Letras, 2006.

COMPARATO, Fábio Konder. A afirmação histórica dos direitos humanos. São Paulo: Saraiva, 2005.

COMPARATO, Fábio Konder. "As garantias institucionais dos Direitos Humanos". Revista Trimestral de Direito Público, Malheiros Editora, n.32, p. 5-13, 2003.

COMPARATO, Fábio Konder. "Fundamentos dos Direitos Humanos". Revista Jurídica Consulex, Ano IV, v.I, n.48, p. 52-61, 2001.

COMPARATO, Fábio Konder. "Direitos Humanos no Brasil: o passado e o futuro. Revista USP, São Paulo., n. 43, p. 168-175, 2000.

DALlARI, Dalmo de Abreu . Direitos humanos e cidadania. São Paulo: Moderna, 2002.

DALLARI, Dalmo de Abreu . Que são direitos da pessoa? 10. ed. São Paulo: Brasiliense, 1994.

DUARTE, Evandro C. Piza, BERTÚlIO, Dora Lúcia de Lima e SILVA, Paulo Vinícius Baptista da (coords.). Cotas raciais no ensino superior. Curitiba: Juruá Editora, 2008.

FARIA, Anacleto de Oliveira. Do princípio da igualdade jurídica. São Paulo: Editora Universidade de São Paulo, 1973.

FERNANDES, Florestan. O negro no mundo dos brancos. São Paulo: Difusão Européia do Livro, 1972.

FERNANDES, Florestan. A integração do negro na sociedade de classses. São Paulo: Ática, 1978, vol. 1.

FERREIRA, Ricardo Franklin. Afro-descendente - identidade em construção. São Paulo: EDUC; Rio de Janeiro: Pallas, 2004.

FERREIRA FILHO, Manoel Gonçalves. "Aspectos jurídicos das ações afirmativas." Revista do Tribunal Superior do Trabalho, Brasília, ano 69, n. 2, p. 72-79, jul./dez.2003.

FERREIRA FILHO, Manoel Gonçalves. Direitos Humanos Fundamentais. São Paulo: Saraiva, 2005

FERREIRA FILHO, Manoel Gonçalves. Curso de Direito Constitucional. São Paulo: Saraiva, 2006.

FLEISCHACKER, Samuel. Uma breve história da justiça distributiva. São Paulo: Martins Fontes, 2006. 
FREYRE, Gilberto. Casa grande \& Senzala. São Paulo: Global Editora, 2006, 51 edição.

FRY, Peter, MAGGIE, Ivone, MAIO, Marcos Chor, MONTEIRO, Simone e SANTOS, Ricardo Ventura (org.). Divisões Perigosas. Rio de Janeiro: Civilização Brasileira, 2007.

FRY, Peter. A persistência da raça. Rio de Janeiro: Civilização Brasileira, 2005.

GOMES, Joaquim B. Barbosa. "As ações afirmativas e os processos da igualdade efetiva". In: Seminário Internacional As Minorias e o Direito. Série Cadernos do CEJ, vol 24, p. 103. Brasília: Conselho da Justiça Federal, Centro de Estudos Judiciários, 2003.

GOMES, Joaquim B. Barbosa. Ação afirmativa \& Princípio Constitucional da Igualdade. $O$ Direito como instrumento de transformação social. Rio de Janeiro: Renovar, 2001 .

GUIMARÃES, Antonio Sérgio Alfredo. Contexto histórico-ideológico do desenvolvimento das ações afirmativas no Brasil. Comunicação ao Seminário Internacional "Ações Afirmativas nas políticas educacionais brasileiras: o contexto pós-Durban", organizado pelo Ministério da Educação e a Câmara Federal, Brasília, 20 a 22 de setembro de 2005. (consulta na internet, www.fflch.usp.br/sociologia/asag/contexto $\% 20$ hist $\% \mathrm{~F} 3$ rico $\% 20 \mathrm{do} \% 20 \mathrm{desenvolvimento} \% 20 \mathrm{~d}$ as $\% 20 \mathrm{a} \% 57 \%$ F5es\%20afirmativa\%85.pdf, acesso em 31/08/2007)

GUIMARÃES, Antônio Sérgio Alfredo. Preconceito e discriminação: queixas de ofensas e tratamento desigual dos negros no Brasil. São Paulo: Editora 34: FUSP, 2004.

GUIMARÃES, Antônio Sérgio Alfredo. “O acesso de negros às universidades públicas”. In: GONÇALVES E SILVA, Petronilha Beatriz; SILVÉRIO, Valter Roberto, (orgs.). Educação e ações afirmativas: entre a injustiça simbólica e a injustiça econômica. Brasília: INEP, 2003.

GUIMARÃES, Antônio Sérgio Alfredo. "Sucesso e cor no vestibular da USP". Informe, edição especial 1999-2001, São Paulo: SDI-FFLCH-USP, 2002.

GUIMARÃES, Antônio Sérgio Alfredo. Classes, raças e democracia. São Paulo: Editora 34, 2002.

GUIMARÃES, Antonio Sérgio Alfredo. Racismo e Anti-Racismo no Brasil. São Paulo: Ed. 34, 1999.

HASENBALG, Carlos Alfredo. Discriminação e desigualdades raciais no Brasil. Rio de Janeiro: Edições Graal, 1979.

HOFBAUER, Andreas. Uma história de branqueamento ou o negro em questão. São Paulo: Editora UNESP, 2006. 
HORIZONTES ANTROPOLÓGICOS. Porto Alegre: UFRG, n.23, jan/jun. 2005. 352 p.

INCLUSP - Programa de Inclusão Social da USP (consulta na internet, www.naeg.prg.usp.br/siteprg/indusp/inclusp_06-06.doc. Acessado em 11-07-2007) internet,

IPEA - Retrato das desigualdades de gênero e raça. Brasília, 2008. Consulta na www.ipea.gov.br/sites/000/2/destaque/Pesquisa Retrato das_Desigualdades.pdf, acesso em 26-11-2008.

KAMEL, Ali. Não somos racistas: uma reação aos que querem nos transformar numa nação bicolor. Rio de Janeiro: Nova Fronteira, 2006.

KAUFMANN, Roberta Fragoso Menezes. Ações afirmativas à brasileira: necessidade ou mito?. Porto Alegre: Livraria do Advogado, 2007.

JACCOUD, Luciana e BEGHIN, Nathalie. Desigualdades raciais no Brasil - um balanço da intervenção governamental. Brasília: IPEA, 2002.

JUNKES, Sérgio Luiz. Defensoria Pública e o Princípio da Justiça Social. Curitiba: Juruá, 2006.

LOPES, Ana Lúcia. Alunos negros-mestiços concluintes do Ensino Superior. In DURHAM, Eunice R.; BORI, Carolina M. (org). Seminário o negro no ensino superior. São Paulo: USP; NUPES, 2002.

LOPES, Cristina (org.). Cotas raciais: Por que sim? Rio de Janeiro: Ibase: Observatório da Cidadania, 2006. Consulta na internet, www.ibase.br/userimages/ibase_cotas_raciais_2.pdf, acesso em 28-6-2008.

MADRUGA, Sidney. Discriminação Positiva: Ações Afirmativas na Realidade Brasileira. Brasília: Brasília Jurídica, 2005.

MAFFETONE, Sebastião \& VECA, Salvatore (orgs). A idéia de justiça de Platão a Rawls. São Paulo: Martins Fontes, 2005.

MAIO, Marcos Chor. "O projeto Unesco e a Agenda das Ciências Sociais no Brasil dos anos 40 e 50." Revista Brasileira de Ciências Sociais. №1 (14): 141-158, outubro/1999. Consulta na internet no endereço www.scielo.br.pdf.rbcsoc/v14n41/1756.pdf, acesso em 27/09/2007.

MELLO, Celso Antônio Bandeira de. "Princípio da Isonomia: Desequiparações proibidas e desequiparações permitidas." Revista Trimestral de Direito Público, n. 1, p. 79-83, 1993. 
MELLO, Celso Antônio Bandeira de. O conteúdo jurídico do princípio da igualdade. São Paulo: Editora Revista dos Tribunais, 1978.

MENEZES, Paulo Lucena de. "A ação afirmativa (affirmative action) no direito norteamericano”. Dissertação de Mestrado, Faculdade de Direito-USP, São Paulo, 2000.

MOEHLECKE, Sabrina. "Propostas de ações afirmativas no Brasil: o acesso da população negra ao ensino superior”. Dissertação de Mestrado, FE-USP, São Paulo: 2000

MOURA, Clóvis. História do negro brasileiro. São Paulo: Ática, 1989.

MUNANGA, Kabengele \& GOMES, Nilma Lino. O negro no Brasil de hoje. São Paulo: Global Editora, 2006.

MUNANGA, Kabengele. "A difícil tarefa de definir quem é negro no Brasil”. Estudos Avançados, São Paulo, v.18, n.50, p.51-56, jan./abr.2004.

MUNANGA, Kabengele. Rediscutindo a mestiçagem no Brasil: identidade nacional versus identidade negra. Belo Horizonte: Autêntica, 2004.

MUNANGA, Kabengele. "Uma abordagem conceitual das noções de raça, racismo, identidade e etnia". In: BRANDÃO, André Augusto P., (org.). Programa de educação sobre o negro na sociedade brasileira. Niterói: EDUFF, 2004.

MUNANGA, Kabengele. "Políticas de ação afirmativa em benefício da população negra no Brasil: um ponto de vista em defesa de cotas". In: GONÇALVES E SILVA, Petronilha Beatriz; SILVÉRIO, Valter Roberto, (orgs.). Educação e ações afirmativas: entre a injustiça simbólica e a injustiça econômica. Brasília: INEP, 2003.

MUNANGA, K. (Org.) . Estratégias e Políticas de Combate à Discriminação Racial. São Paulo: EDUSP/Estação Ciência, 1996.

MUNANGA, Kabengele. "A identidade negra no contexto da globalização". Ethnos Brasil, São Paulo, v.1, n.1, p.11-20, mar. 2002.

MUNANGA, Kabengele. "Mestiçagem e experiências interculturais no Brasil". In:SCHWARCZ, Lilia Moritz, REIS, Letícia Vidor de Souza (org.). Negras imagens: ensaios sobre cultura e escravidão no Brasil. São Paulo: Edusp, 1996.

NASCIMENTO, Abdias do e NASCIMENTO, Elisa Larkin. "Reflexões sobre o Movimento Negro no Brasil, 1938-1997." In: GUIMARÃES, Antonio Sérgio Alfredo e HUNTLEY, Lynn (org.). Tirando a máscara - ensaios sobre o racismo no Brasil. São Paulo: Paz e Terra, 2000.

NINA RODRIGUES, R. As raças humanas e a responsabilidade penal no Brazil. Bahia, 1894. consulta na internet, endereço http://bdjur.stj.gov.br, acesso em 23-11-2007. 
NINA RODRIGUES, R. Os africanos no Brasil. São Paulo: Nacional, Brasília: Universidade de Brasília, 1988.

NUNES, Margarete Fagundes (org.). Diversidade e Políticas Afirmativas: diálogos e intercursos. Novo Hamburgo: Feevale, 2005.

QUEIROZ, Delcele MascarenhasSANTOS, Jocélio Teles dos. Sistema de cotas: um debate. Dos dados à manutenção de privilégios e de poder. Educ. Soc. [online]. 2006, vol. 27, no. 962008-11-05], pp. 717-737. Consulta na internet, endereço http://www.scielo.br/scielo.php?script $=$ sci arttext\&pid $=\mathrm{S} 0101-$

73302006000300005\&lng=\&nrm=iso, acesso em 05-11-2008.

QUEIROZ, Delcele Mascarenhas (coord). O negro na universidade. Salvador: Novos Toques, 2002.

PAIVA, Ângela Randolpho org. Ação Afirmativa na universidade: reflexão sobre experiências concretas Brasil - Estados Unidos. Rio de Janeiro: Editora PUC-Rio, 2004.

PAIXÃO, Marcelo, CARVANO, Luiz M. (orgs). Relatório Anual das Desigualdades Raciais no Brasil; 2007-2008. Rio de Janeiro: Garamond, 2008.

PLATÃO. A República. Bauru: Edipro, 1994.

PROGRAMA DAS NAÇÕES UNIDAS PARA O DESENVOLVIMENTO (PNUD). Relatório de Desenvolvimento Humano - Brasil 2005. (consulta na internet, endereço: www.pnud.org.br)

PRUDENTE, Eunice Aparecida de Jesus. "O negro na ordem jurídica brasileira". Revista da Faculdade de Direito USP, São Paulo, V.83, 1988.

PRUDENTE, Eunice Aparecida de Jesus. Preconceito racial e igualdade jurídica no Brasil. São Paulo: Julex Livros Ltda, 1989.

RAMOS, Sílvia. Mídia e racismo. Rio de Janeiro: Pallas Editora, 2002.

RAWLS, John. Justiça como eqüidade - Uma reformulação. São Paulo: Martins Fontes, 2003

RAWLS, John. Uma teoria da justiça. São Paulo: Martins Fontes, 2002.

RAWLS, John. Justiça e Democracia. São Paulo: Martins Fontes, 2000.

RAWLS, John. O liberalismo político. São Paulo: Ática, 2000.

RAWLS, John. Uma teoria da justiça. Lisboa: Presença, 1993. 
RELATÓRIO DO COMITÊ NACIONAL PARA A PREPARAÇÃO DA PARTICIPAÇÃO BRASILEIRA NA III CONFERÊNCIA MUNDIAL DAS NAÇÕES UNIDAS CONTRA O RACISMO, DISCRIMINAÇÃO RACIAL, XENOFOBIA E INTOLERÂNCIA CORRELATA (Durban, 31 de agosto a 07 de setembro de 2001). Brasília: Ministério da Justiça, Secretaria de Estado dos Direitos Humanos, 2001.

REVISTA USP. São Paulo: USP, n. 68, dez/fev. 2005/2006. 341 p.

REVISTA USP. São Paulo: USP, n. 69, mar/mai. 2006. 208 p.

RODRIGUES, João Jorge Santos. "Direito e ação afirmativa: as políticas de ação afirmativa para afro-brasileiros. Acesso ao ensino superior." Dissertação de Mestrado, Faculdade de Direito-UnB, Brasília, 2005.

SANÉ, Pierre. Reinvidicações articuladas (e contestadas) de reparação dos crimes da História, a propósito da escravidão e do colonialismo, por ocasião da Conferência de Durban. Genebra: 2002. (consulta na internet, endereço www.unesco.org.br/publicacoes).

SANTOS, João Paulo de Faria. Ações afirmativas e igualdade racial. São Paulo: Edições Loyola, 2005.

SANTOS, Renato Emerson do; LOBATO, Fátima (orgs.) Ações afirmativas: políticas públicas contra as desigualdades raciais. Rio de Janeiro: DP \& A, 2003.

SCHWARCZ, Lilia Moritz, REIS, Letícia Vidor de Souza (org.). Negras imagens: ensaios sobre cultura e escravidão no Brasil. São Paulo: Edusp, 1996.

SCHWARCZ, Lilia Moritz."Usos e abusos da mestiçagem e da raça no Brasil: uma história das teorias raciais em finais do século XIX”. Afro-Ásia, n.18, 1996, p 77-101.

SELL, Sandro César. Ação afirmativa e democracia racial: uma introdução ao debate no Brasil. Florianópolis: Fundação Boiteux, 2002.

SKIDMORE, Thomas E. Preto no Branco. Rio de Janeiro: Editora Paz e Terra, 1989.

SISS, Ahyas. Afro-brasileiros, cotas e ação afirmativa: razões históricas. Rio de Janeiro: Quartet, 2003.

SILVA Jr., Hédio. Direito de igualdade racial aspectos constitucionais, civis e penais. São Paulo: Editora Juarez de Oliveira, 2002.

SILVA, Jorge. "Política de ação afirmativa para a população negra: educação, trabalho e participação no poder". In: VOGEL, Arno (org.). Trabalhando com a diversidade no Planfor: raça/cor, gênero e pessoas portadoras de necessidades especiais. UNESP: Brasília, 2000. 
SILVA, José Afonso. Curso de Direito Constitucional Positivo. São Paulo: Malheiros Editores, 2000.

SILVA, Marcelo Amaral. Digressões acerca do princípio constitucional da igualdade. (consulta na internet, endereço //jus2.uol.com.br/doutrina/texto.asp?id=4143, acesso em 17/06/2006)

SOARES, Eliane Veras, et al. O dilema racial brasileiro: de Roger Bastide a Florestan Fernandes ou da explicação teórica à proposição política. (consulta na internet, endereço www.revistas.ufg.br/index.php/fchf/article/view/551/474.pdf, acesso em 25/09/2007). 
10. Anexos 


\section{ANEXO 1 \\ "Todos têm direitos iguais na República ${ }^{372}$}

O princípio da igualdade política e jurídica dos cidadãos é um fundamento essencial da República e um dos alicerces sobre o qual repousa a Constituição brasileira. Este princípio encontra-se ameaçado de extinção por diversos dispositivos dos projetos de lei de Cotas (PL 73/1999) e do Estatuto da Igualdade Racial (PL 3.198/2000) que logo serão submetidos a uma decisão final no Congresso Nacional.

O PL de Cotas torna compulsória a reserva de vagas para negros e indígenas nas instituições federais de ensino superior. O chamado Estatuto da Igualdade Racial implanta uma classificação racial oficial dos cidadãos brasileiros, estabelece cotas raciais no serviço público e cria privilégios nas relações comerciais com o poder público para empresas privadas que utilizem cotas raciais na contratação de funcionários. Se forem aprovados, a nação brasileira passará a definir os direitos das pessoas com base na tonalidade da sua pele, pela "raça". A história já condenou dolorosamente estas tentativas.

Os defensores desses projetos argumentam que as cotas raciais constituem política compensatória voltada para amenizar as desigualdades sociais. O argumento é conhecido: temos um passado de escravidão que levou a população de origem africana a níveis de renda e condições de vida precárias. O preconceito e a discriminação contribuem para que esta situação pouco se altere. Em decorrência disso, haveria a necessidade de políticas sociais que compensassem os que foram prejudicados no passado, ou que herdaram situações desvantajosas. Essas politicas, ainda que reconhecidamente imperfeitas, se justificariam porque viriam a corrigir um mal maior.

Esta análise não é realista nem sustentável e tememos as possiveis conseqüências das cotas raciais. Transformam classificações estatísticas gerais (como as do IBGE) em identidades e direitos individuais contra o preceito da igualdade de todos perante a lei. A adoção de identidades raciais não deve ser imposta e regulada pelo Estado. Políticas dirigidas a grupos "raciais" estanques em nome da justiça social não eliminam o racismo e podem até mesmo produzir o efeito contrário, dando respaldo legal ao conceito de raça, e possibilitando o acirramento do conflito e da intolerância. A verdade amplamente reconhecida é que o principal caminho para o combate à exclusão social é a construção de serviços públicos universais de qualidade nos setores de educação, saúde e previdência, em especial a criação de empregos. Essas metas só poderão ser alcançadas pelo esforço comum de cidadãos de todos os tons de pele contra privilégios odiosos que limitam o alcance do princípio republicano da igualdade política e jurídica.

A invenção de raças oficiais tem tudo para semear esse perigoso tipo de racismo, como

372 A carta pode ser encontrada na íntegra, com os respectivos signatários no site www1.folha.uol.com.br/folha/educação/ult305u18773.shtml, acesso em 10/09/2008. 
demonstram exemplos históricos e contemporâneos. E ainda bloquear o caminho para a resolução real dos problemas de desigualdades.

Qual Brasil queremos? Almejamos um Brasil no qual ninguém seja discriminado, de forma positiva ou negativa, pela sua cor, seu sexo, sua vida íntima e sua religião; onde todos tenham acesso a todos os serviços públicos; que se valorize a diversidade como um processo vivaz e integrante do caminho de toda a humanidade para um futuro onde a palavra felicidade não seja um sonho. Enfim, que todos sejam valorizados pelo que são e pelo que conseguem fazer. Nosso sonho é o de Martin Luther King, que lutou para viver numa nação onde as pessoas não seriam avaliadas pela cor de sua pele, mas pela força de seu caráter.

Nos dirigimos ao congresso nacional, seus deputados e senadores, pedindo-lhes que recusem o PL 73/1999 (PL das Cotas) e o PL 3.198/2000 (PL do Estatuto da Igualdade Racial) em nome da República Democrática.

Rio de Janeiro, 30 de maio de 2006." 


\section{ANEXO 2 \\ "Manifesto em favor da lei de cotas e do estatuto da igualdade racial ${ }^{373}$}

Aos/as deputados/as e senadores/as do Congresso brasileiro

A desigualdade racial no Brasil tem fortes raizes históricas e esta realidade não será alterada significativamente sem a aplicação de políticas públicas específicas. A Constituição de 1891 facilitou a reprodução do racismo ao decretar uma igualdade puramente formal entre todos os cidadãos. A população negra acabava de ser colocada em uma situação de completa exclusão em termos de acesso à terra, à instrução e ao mercado de trabalho para competir com os brancos diante de uma nova realidade econômica que se instalava no país. Enquanto se dizia que todos eram iguais na letra da lei, várias políticas de incentivo e apoio diferenciado, que hoje podem ser lidas como ações afirmativas, foram aplicadas para estimular a imigração de europeus para o Brasil.

Esse mesmo racismo estatal foi reproduzido e intensificado na sociedade brasileira ao longo de todo o século vinte. Uma série de dados oficiais sistematizados pelo IPEA no ano 2001 resume o padrão brasileiro de desigualdade racial: por 4 gerações ininterruptas, pretos e pardos têm contado com menos escolaridade, menos salário, menos acesso à saúde, menor indice de emprego, piores condições de moradia, quando contrastados com os brancos e asiáticos. Estudos desenvolvidos nos últimos anos por outros organismos estatais demonstram claramente que a ascensão social e econômica no país passa necessariamente pelo acesso ao ensino superior.

Foi a constatação da extrema exclusão dos jovens negros e indígenas das universidades que impulsionou a atual luta nacional pelas cotas, cujo marco foi a Marcha Zumbi dos Palmares pela Vida, em 20 de novembro de 1995, encampada por uma ampla frente de solidariedade entre acadêmicos negros e brancos, coletivos de estudantes negros, cursinhos pré-vestibulares para afrodescendentes e pobres e movimentos negros da sociedade civil, estudantes e líderes indígenas, além de outros setores solidários, como jornalistas, líderes religiosos e figuras políticas --boa parte dos quais subscreve o presente documento. A justiça e o imperativo moral dessa causa encontraram ressonância nos últimos governos, o que resultou em políticas públicas concretas, dentre elas: a criação do Grupo de Trabalho Interministerial para a Valorização da População Negra, de 1995; as primeiras ações afirmativas no âmbito dos Ministérios, em 2001; a criação da Secretaria Especial para Promoção de Políticas da Igualdade Racial (SEPPIR), em 2003; e, finalmente, a proposta dos atuais Projetos de Lei que estabelecem cotas para estudantes negros oriundos da escola pública em todas as universidades federais brasileiras, e o Estatuto da Igualdade Racial.

O PL 73/99 (ou Lei de Cotas) deve ser compreendido como uma resposta coerente e responsável do Estado brasileiro aos vários instrumentos jurídicos internacionais a que aderiu, tais como a Convenção da ONU para a Eliminação de Todas as Formas de

373 O manifesto pode ser encontrado na íntegra, com os respectivos signatários, no site: www1.folha.uol.com.br/folha/educação/ult305u18773.shtml, acesso em 10/09/2008 
Discriminação Racial (CERD), de 1969, e, mais recentemente, ao Plano de Ação de Durban, resultante da III Conferência Mundial de Combate ao Racismo, Discriminação Racial, Xenofobia e Intolerância Correlata, ocorrida em Durban, na África do Sul, em 2001. O Plano de Ação de Durban corrobora a ênfase, já colocada pela CERD, de adoção de ações afirmativas como um mecanismo importante na construção da igualdade racial, uma vez aqui que as ações afirmativas para minorias étnicas e raciais já se efetivam em inúmeros países multi-étnicos e multi-raciais semelhantes ao Brasil. Foram incluídas na Constituição da Índia, em 1949; adotadas pelo Estado da Malásia desde 1968; nos Estados Unidos desde 1972; na África do Sul, em 1994; e desde então no Canadá, na Austrália, na Nova Zelândia, na Colômbia e no México. Existe uma forte expectativa internacional de que o Estado brasileiro finalmente implemente politicas consistentes de ações afirmativas, inclusive porque o país conta com a segunda maior população negra do planeta e deve reparar as assimetrias promovidas pela intervenção do Estado da Primeira República com leis que outorgaram benefícios especiais aos europeus recém chegados, negando explicitamente os mesmos benefícios à população afro-brasileira.

Colocando o sistema acadêmico brasileiro em uma perspectiva internacional, concluímos que nosso quadro de exclusão racial no ensino superior é um dos mais extremos do mundo. Para se ter uma idéia da desigualdade racial brasileira, lembremos que, mesmo nos dias do apartheid, os negros da África do Sul contavam com uma escolaridade média maior que a dos negros no Brasil no ano 2000; a porcentagem de professores negros nas universidades sulafricanas, ainda na época do apartheid, era bem maior que a porcentagem dos professores negros nas nossas universidades públicas nos dias atuais. A porcentagem média de docentes nas universidades públicas brasileiras não chega a 1\%, em um país onde os negros conformam 45,6 \% do total da população. Se os Deputados e Senadores, no seu papel de traduzir as demandas da sociedade brasileira em politicas de Estado não intervierem aprovando o PL 73/99 e o Estatuto, os mecanismos de exclusão racial embutidos no suposto universalismo do estado republicano provavelmente nos levarão a atravessar todo o século XXI como um dos sistemas universitários mais segregados étnica e racialmente do planeta! E, pior ainda, estaremos condenando mais uma geração inteira de secundaristas negros a ficar fora das universidades, pois, segundo estudos do IPEA, serão necessários 30 anos para que a população negra alcance a escolaridade média dos brancos de hoje, caso nenhuma política especifica de promoção da igualdade racial na educação seja adotada. Para que nossas universidades públicas cumpram verdadeiramente sua função republicana e social em uma sociedade multi-étnica e multi-racial, deverão algum dia refletir as porcentagens de brancos, negros e indígenas do país em todos os graus da hierarquia acadêmica: na graduação, no mestrado, no doutorado, na carreira de docente e na carreira de pesquisador.

No caminho da construção dessa igualdade étnica e racial, somente nos últimos 4 anos, mais de 30 universidades e Instituições de Ensino Superior públicas, entre federais e estaduais, já implementaram cotas para estudantes negros, indígenas e alunos da rede pública nos seus vestibulares e a maioria adotou essa medida após debates no interior dos seus espaços acadêmicos. Outras 15 instituições públicas estão prestes a adotar políticas semelhantes. Todos os estudos de que dispomos já nos permitem afirmar com segurança que o rendimento acadêmico dos cotistas é, em geral, igual ou superior ao rendimento dos alunos que entraram pelo sistema universal. Esse dado é importante porque desmonta um preconceito muito difundido de que as cotas conduziriam a um rebaixamento da qualidade acadêmica das 
universidades. Isso simplesmente não se confirmou! Uma vez tida a oportunidade de acesso diferenciado (e insistimos que se trata de cotas de entrada e não de saída), o rendimento dos estudantes negros não se distingue do rendimento dos estudantes brancos.

Outro argumento muito comum usado por aqueles que são contra as políticas de inclusão de estudantes negros por intermédio de cotas é que haveria um acirramento dos conflitos raciais nas universidades. Muito distante desse panorama alarmista, os casos de racismo que têm surgido após a implementação das cotas têm sido enfrentados e resolvidos no interior das comunidades acadêmicas, em geral com transparência e eficácia maiores do que havia antes das cotas. Nesse sentido, a prática das cotas tem contribuído para combater o clima de impunidade diante da discriminação racial no meio universitário. Mais ainda, as múltiplas experiências de cotas em andamento nos últimos 4 anos contribuíram para a formação de uma rede de especialistas e de uma base de dados acumulada que facilitará a implementação, a nível nacional, da Lei de Cotas.

Para que tenhamos uma noção da escala de abrangência dessas leis a serem votadas o PL 73/99, que reserva vagas na graduação, é uma medida ainda tímida: garantirá uma média nacional mínima de 22,5\% de vagas nas universidades públicas para um grupo humano que representa 45,6\% da população nacional. É preciso, porém, ter clareza do que significam esses $22,5 \%$ de cotas no contexto total do ensino de graduação no Brasil. Tomando como base os dados oficiais do INEP, o número de ingressos nas universidades federais em 2004 foi de 123.000 estudantes, enquanto o total de ingressos em todas as universidades (federais, estaduais, municipais e privadas) foi de 1.304 .000 estudantes. Se já tivessem existido cotas em todas as universidades federais para esse ano, os estudantes negros contariam com uma reserva de 27.675 vagas (22,5\% de 123.000 vagas). Em suma, a Lei de Cotas incidiria em apenas 2\% do total de ingressos no ensino superior brasileiro. Devemos concluir que a desigualdade racial continuará sendo a marca do nosso universo acadêmico durante décadas, mesmo com a implementação do PL 73/99. Sem as cotas, porém, já teremos que começar a calcular em séculos a perspectiva de combate ao nosso racismo universitário. Temos esperança de que nossos congressistas aumentem esses índices tão baixos de inclusão!

Se a Lei de Cotas visa nivelar o acesso às vagas de ingresso nas universidades públicas entre brancos e negros, o Estatuto da Igualdade Racial complementa esse movimento por justiça. Garante o acesso mínimo dos negros aos cargos públicos e assegura um mínimo de igualdade racial no mercado de trabalho e no usufruto dos serviços públicos de saúde e moradia, entre outros. Nesse sentido, o Estatuto recupera uma medida de igualdade que deveria ter sido incluída na Constituição de 1891, no momento inicial da construção da República no Brasil. Foi sua ausência que aprofundou o fosso da desigualdade racial e da impunidade do racismo contra a população negra ao longo de todo o século XX. Por outro lado, o Estatuto transforma em ação concreta os valores de igualdade plasmados na Constituição de 1988, claramente pró-ativa na sua afirmação de que é necessário adotar mecanismos capazes de viabilizar a igualdade almejada. Enquanto o Estatuto não for aprovado, continuaremos reproduzindo o ciclo de desigualdade racial profunda que tem sido a marca de nossa história republicana até os dias de hoje.

Gostaríamos ainda de fazer uma breve menção ao documento contrário à Lei de Cotas e ao Estatuto da Igualdade Racial, enviado recentemente aos nobres parlamentares por um grupo 
de acadêmicos pertencentes a várias instituições de elite do país. Ao mesmo tempo em que rejeitam frontalmente as duas Leis em discussão, os assinantes do documento não apresentam nenhuma proposta alternativa concreta de inclusão racial no Brasil, reiterando apenas que somos todos iguais perante a lei e que é preciso melhorar os serviços públicos até atenderem por igual a todos os segmentos da sociedade. Essa declaração de princípios universalistas, feita por membros da elite de uma sociedade multi-étnica e multi-racial com uma história recente de escravismo e genocídio sistemático, parece uma reedição, no século XXI, do imobilismo subjacente à Constituição da República de 1891: zerou, num toque de mágica, as desigualdades causadas por séculos de exclusão e racismo, e jogou para um futuro incerto o dia em que negros e índios poderão ter acesso eqüitativo à educação, às riquezas, aos bens $e$ aos serviços acumulados pelo Estado brasileiro. Essa postergação consciente não é convincente. Diante dos dados oficiais recentes do IBGE e do IPEA que expressam, sem nenhuma dúvida, a nossa dívida histórica com os negros e os índios, ou adotamos cotas e implementamos o Estatuto, ou seremos coniventes com a perpetuação da nossa desigualdade étnica e racial.

Acreditamos que a igualdade universal dentro da República não é um princípio vazio e sim uma meta a ser alcançada. As ações afirmativas, baseadas na discriminação positiva daqueles lesados por processos históricos, são a figura jurídica criada pelas Nações Unidas para alcançar essa meta.

Conclamamos, portanto, os nossos ilustres congressistas a que aprovem, com a máxima urgência, a Lei de Cotas (PL73/1999) e o Estatuto da Igualdade Racial (PL 3.198/2000).

Brasilia, 3 de julho de 2006." 


\section{ANEXO 3 \\ “Cidadãos Anti-Racistas Contra as Leis Raciais ${ }^{374}$}

Excelentíssimo sr. ministro:

Duas ações diretas de inconstitucionalidade (ADI 3.330 e ADI 3.197) promovidas pela Confenen (Confederação Nacional dos Estabelecimentos de Ensino), a primeira contra o programa ProUni e a segunda contra a lei de cotas nos concursos vestibulares das universidades estaduais do Rio de Janeiro, serão apreciadas proximamente pelo STF. Os julgamentos terão significado histórico, pois podem criar jurisprudência sobre a constitucionalidade de cotas raciais não só para o financiamento de cursos no ensino superior particular e para concursos de ingresso no ensino superior público como para concursos públicos em geral. Mais ainda: os julgamentos têm o potencial de enviar uma mensagem decisiva sobre a constitucionalidade da produção de leis raciais.

Nós, intelectuais da sociedade civil, sindicalistas, empresários e ativistas dos movimentos negros e outros movimentos sociais, dirigimo-nos respeitosamente aos juízes da corte mais alta, que recebeu do povo constituinte a prerrogativa de guardiã da Constituição, para oferecer argumentos contrários à admissão de cotas raciais na ordem política e jurídica da República.

Na seara do que Vossas Excelências dominam, apontamos a Constituição Federal, no seu artigo 19, que estabelece: "É vedado à União, aos Estados, ao Distrito Federal e aos Municípios criar distinções entre brasileiros ou preferências entre si." $O$ artigo 208 dispõe que: "O dever do Estado com a educação será efetivado mediante a garantia de acesso aos níveis mais elevados do ensino, da pesquisa e da criação artística, segundo a capacidade de cada um." Alinhada com os princípios e garantias da Constituição Federal, a Constituição Estadual do Rio de Janeiro, no seu Artigo 9o, determina que: "Ninguém será discriminado, prejudicado ou privilegiado em razão de nascimento, idade, etnia, raça, cor, sexo, estado civil, trabalho rural ou urbano, religião, convicções políticas ou filosóficas, deficiência fisica ou mental, por ter cumprido pena nem por qualquer particularidade ou condição."

As palavras da lei emanam de uma tradição brasileira, que cumpre exatos 120 anos desde a Abolição da escravidão, de não dar amparo a leis e políticas raciais. No intuito de justificar o rompimento dessa tradição, os proponentes das cotas raciais sustentam que o princípio da igualdade de todos perante a lei exige tratar desigualmente os desiguais. Ritualmente, eles citam a "Oração aos Moços", na qual Rui Barbosa, inspirado em Aristóteles, explica que: "A regra da igualdade não consiste senão em aquinhoar desigualmente aos desiguais, na medida em que se desigualam. Nesta desigualdade social, proporcionada à desigualdade natural, é que se acha a verdadeira lei da igualdade." $O$ método de tratar desigualmente os desiguais, a que se refere, é aquele aplicado, com justiça,

374 O manifesto pode ser encontrada na íntegra, com os respectivos signatários no site www1.folha.uol.com.br/folha/educação/ult305u401519.shtml, acesso em 10/09/2008. 
em campos tão distintos quanto o sistema tributário, por meio da tributação progressiva, e as políticas sociais de transferência de renda. Mas a sua invocação para sustentar leis raciais não é mais que um sofisma.

Os concursos vestibulares, pelos quais se dá o ingresso no ensino superior de qualidade "segundo a capacidade de cada um", não são promotores de desigualdades, mas se realizam no terreno semeado por desigualdades sociais prévias. A pobreza no Brasil tem todas as cores. De acordo com dados da PNAD (Pesquisa Nacional por Amostra de Domicílios) de 2006, entre 43 milhões de pessoas de 18 a 30 anos de idade, 12,9 milhões tinham renda familiar per capita de meio salário mínimo ou menos. Neste grupo mais pobre, 30\% classificavam-se a si mesmos como brancos, 9\% como pretos e $60 \%$ como pardos. Desses 12,9 milhões, apenas $21 \%$ dos brancos e $16 \%$ dos pretos e pardos haviam completado o ensino médio, mas muito poucos, de qualquer cor, continuaram estudando depois disso. Basicamente, são diferenças de renda, com tudo que vem associado a elas, e não de cor, que limitam o acesso ao ensino superior.

Apresentadas como maneira de reduzir as desigualdades sociais, as cotas raciais não contribuem para isso, ocultam uma realidade trágica e desviam as atenções dos desafios imensos e das urgências, sociais e educacionais, com os quais se defronta a nação. E, contudo, mesmo no universo menor dos jovens que têm a oportunidade de almejar o ensino superior de qualidade, as cotas raciais não promovem a igualdade, mas apenas acentuam desigualdades prévias ou produzem novas desigualdades: "As cotas raciais exclusivas, como aplicadas, entre outras, na UnB (Universidade de Brasília), proporcionam a um candidato definido como negro a oportunidade de ingresso por menor número de pontos que um candidato definido como branco, mesmo se o primeiro provier de familia de alta renda e tiver cursado colégios particulares de excelência e o segundo provier de familia de baixa renda e tiver cursado escolas públicas arruinadas. No fim, o sistema concede um privilégio para candidatos de classe média arbitrariamente classificados como negros.

"As cotas raciais embutidas no interior de cotas para candidatos de escolas públicas, como aplicadas, entre outras, pela Uerj (Universidade Estadual do Rio de Janeiro), separam os alunos provenientes de familias com faixas de renda semelhantes em dois grupos raciais polares, gerando uma desigualdade natural num meio caracterizado pela igualdade social. $O$ seu resultado previsivel é oferecer privilégios para candidatos definidos arbitrariamente como negros que cursaram escolas públicas de melhor qualidade, em detrimento de seus colegas definidos como brancos e de todos os alunos de escolas públicas de pior qualidade.

A PNAD de 2006 informa que 9,41 milhões de estudantes cursavam o ensino médio, mas apenas 5,87 milhões freqüentavam o ensino superior, dos quais só uma minoria de 1,44 milhão estavam matriculados em instituições superiores públicas. As leis de cotas raciais não alteram em nada esse quadro e não proporcionam inclusão social. Elas apenas selecionam vencedores e perdedores, com base num critério altamente subjetivo e intrinsecamente injusto, abrindo cicatrizes profundas na personalidade dos jovens, naquele momento de extrema fragilidade que significa a disputa, ainda imaturos, por uma vaga que lhes garanta o futuro. 
Queremos um Brasil onde seus cidadãos possam celebrar suas múltiplas origens, que se plasmam na criação de uma cultura nacional aberta e tolerante, no lugar de sermos obrigados a escolher e valorizar uma única ancestralidade em detrimento das outras. O que nos mobiliza não é o combate à doutrina de ações afirmativas, quando entendidas como esforço para cumprir as declarações preambulares da Constituição, contribuindo na redução das desigualdades sociais, mas a manipulação dessa doutrina com o propósito de racializar a vida social no país. As leis que oferecem oportunidades de emprego a deficientes físicos e que concedem cotas a mulheres nos partidos políticos são invocadas como precedentes para sustentar a admissibilidade jurídica de leis raciais. Esse segundo sofisma é ainda mais grave, pois conduz à naturalização das raças. Afinal, todos sabemos quem são as mulheres e os deficientes físicos, mas a definição e delimitação de grupos raciais pelo Estado é um empreendimento político que tem como ponto de partida a negação daquilo que nos explicam cientistas.

Raças humanas não existem. A genética comprovou que as diferenças icônicas das chamadas raças humanas são características físicas superficiais, que dependem de parcela ínfima dos 25 mil genes estimados do genoma humano. A cor da pele, uma adaptação evolutiva aos níveis de radiação ultravioleta vigentes em diferentes áreas do mundo, é expressa em menos de dez genes! Nas palavras do geneticista Sérgio Pena: "O fato assim cientificamente comprovado da inexistência das 'raças' deve ser absorvido pela sociedade e incorporado às suas convicções e atitudes morais. Uma postura coerente e desejável seria a construção de uma sociedade desracializada, na qual a singularidade do individuo seja valorizada e celebrada. Temos de assimilar a noção de que a única divisão biologicamente coerente da espécie humana é em bilhões de indivíduos, e não em um punhado de 'raças'."

Não foi a existência de raças que gerou o racismo, mas o racismo que fabricou a crença em raças. $O$ "racismo cientifico" do século 19 acompanhou a expansão imperial européia na África e na Ásia, erguendo um pilar "científico" de sustentação da ideologia da "missão civilizatória" dos europeus, que foi expressa celebremente como o "fardo do homem branco".

Os poderes coloniais, para separar na lei os colonizadores dos nativos, distinguiram também os nativos entre si e inscreveram essas distinções nos censos. A distribuição de privilégios segundo critérios etno-raciais inculcou a raça nas consciências e na vida política, semeando tensões e gestando conflitos que ainda perduram. Na África do Sul, o sistema do apartheid separou os brancos dos demais e foi adiante, na sua lógica implacável, fragmentando todos os não-brancos em grupos étnicos cuidadosamente delimitados. Em Ruanda, no Quênia e em tantos outros lugares, os africanos foram submetidos a meticulosas classificações étnicas, que determinaram acessos diferenciados aos serviços e empregos públicos. A produção política da raça é um ato político que não demanda diferenças de cor da pele.

O racismo contamina profundamente as sociedades quando a lei sinaliza às pessoas que elas pertencem a determinado grupo racial_e que seus direitos são afetados por esse critério de pertinência de raça. Nos Estados Unidos, modelo por excelência das políticas de cotas raciais, a abolição da escravidão foi seguida pela produção de leis raciais baseadas na regra da "gota de sangue única". Essa regra, que é a negação da mestiçagem biológica e cultural, propiciou a divisão da sociedade em guetos legais, sociais, culturais e espaciais. De acordo 
com ela, as pessoas são, irrevogavelmente, brancas ou negras. Eis aí a inspiração das leis de cotas raciais no Brasil.

"Eu tenho o sonho que meus quatro pequenos filhos viverão um dia numa nação na qual não serão julgados pela cor da sua pele mas pelo conteúdo de seu caráter." Há 45 anos, em agosto, Martin Luther King abriu um horizonte alternativo para os norte-americanos, ancorando-o no "sonho americano" e no princípio político da igualdade de todos perante a lei, sobre o qual foi fundada a nação. Mas o desenvolvimento dessa visão pós-racial foi interrompido pelas politicas racialistas que, a pretexto de reparar injustiças, beberam na fonte envenenada da regra da "gota de sangue única". De lá para cá, como documenta extensamente Thomas Sowell em "Ação Afirmativa ao Redor do Mundo: um Estudo Empírico", as cotas raciais nos Estados Unidos não contribuíram em nada para reduzir desigualdades, mas aprofundaram o cisma racial que marca como ferro em brasa a sociedade norte-americana.

"É um impasse racial no qual estamos presos há muitos anos", na constatação do senador Barack Obama, em seu discurso pronunciado a 18 de março, que retoma o fio perdido depois do assassinato de Martin Luther King. O impasse não será superado tão cedo, em virtude da lógica intrínseca das leis raciais. Como assinalou Sowell, com base em exemplos de inúmeros países, a distribuição de privilégios segundo critérios etno-raciais tende a retroalimentar as percepções racializadas da sociedade _e em torno dessas percepções articulam-se carreiras politicas e grupos organizados de pressão.

Mesmo assim, algo se move nos Estados Unidos. Há pouco, repercutindo um desencanto social bastante generalizado com o racialismo, a Suprema Corte declarou inconstitucionais as políticas educacionais baseadas na aplicação de rótulos raciais às pessoas. No seu argumento, o presidente da corte, juiz John G. Roberts Jr., escreveu que "o caminho para acabar com a discriminação baseada na raça é acabar com a discriminação baseada na raça". Há um sentido claro na reiteração: a inversão do sinal da discriminação consagra a raça no domínio da lei, destruindo o princípio da cidadania.

Naquele julgamento, o juiz Anthony Kennedy alinhou-se com a maioria, mas proferiu um voto separado que contém o seguinte protesto: "Quem exatamente é branco e quem é nãobranco? Ser forçado a viver sob um rótulo racial oficial é inconsistente com a dignidade dos individuos na nossa sociedade. E é um rótulo que um indivíduo é impotente para mudar!" Nos censos do IBGE, as informações de raça/ cor abrigam a mestiçagem e recebem tratamento populacional. As leis raciais no Brasil são algo muito diferente: elas têm o propósito de colar "um rótulo que um indivíduo é impotente para mudar" e, no caso das cotas em concursos vestibulares, associam nominalmente cada jovem candidato a uma das duas categorias raciais polares, impondo-lhes uma irrecorrível identidade oficial.

O juiz Kennedy foi adiante e, reconhecendo a diferença entre a doutrina de ações afirmativas e as políticas de cotas raciais, sustentou a legalidade de iniciativas voltadas para a promoção ativa da igualdade que não distinguem os individuos segundo rótulos raciais. Reportando-se à realidade norte-americana da persistência dos guetos, ele mencionou, entre outras, a seleção de áreas residenciais racialmente segregadas para os investimentos prioritários em educação pública. 
No Brasil, difunde-se a promessa sedutora de redução gratuita das desigualdades por meio de cotas raciais para ingresso nas universidades. Nada pode ser mais falso: as cotas raciais proporcionam privilégios a uma ínfima minoria de estudantes de classe média e conservam intacta, atrás de seu manto falsamente inclusivo, uma estrutura de ensino público arruinada. Há um programa inteiro de restauração da educação pública a se realizar, que exige políticas adequadas e vultosos investimentos. É preciso elevar o padrão geral do ensino mas, sobretudo, romper o abismo entre as escolas de qualidade, quase sempre situadas em bairros de classe média, e as escolas devastadas das periferias urbanas, das favelas e do meio rural. O direcionamento prioritário de novos recursos para esses espaços de pobreza beneficiaria jovens de baixa renda de todos os tons de pele --e, certamente, uma grande parcela daqueles que se declaram pardos e pretos.

A meta nacional deveria ser proporcionar a todos um ensino básico de qualidade e oportunidades verdadeiras de acesso à universidade. Mas há iniciativas a serem adotadas, imediatamente, em favor de jovens de baixa renda de todas as cores que chegam aos umbrais do ensino superior, como a oferta de cursos preparatórios gratuitos e a eliminação das taxas de inscrição nos exames vestibulares das universidades públicas. Na Unesp (Universidade Estadual Paulista), o Programa de Cursinhos Pré-Vestibulares Gratuitos, destinado a alunos egressos de escolas públicas, atendeu em 2007 a 3.714 jovens, dos quais 1.050 foram aprovados em concursos vestibulares, sendo 707 em universidades públicas. Medidas como essa, que não distinguem os indivíduos segundo critérios raciais abomináveis, têm endereço social certo e contribuem efetivamente para a amenização das desigualdades.

A sociedade brasileira não está livre da chaga do racismo, algo que é evidente no cotidiano das pessoas com tom de pele menos claro, em especial entre os jovens de baixa renda. A cor conta, ilegal e desgraçadamente, em incontáveis processos de admissão de funcionários. A discriminação se manifesta de múltiplas formas, como por exemplo na hora das incursões policiais em bairros periféricos ou nos padrões de aplicação de ilegais mandados de busca coletivos em áreas de favelas.

Por certo existe preconceito racial e racismo no Brasil, mas o Brasil não é uma nação racista. Depois da abolição, no lugar da regra da "gota de sangue única", a nação brasileira elaborou uma identidade amparada na idéia anti-racista de mestiçagem e produziu leis que criminalizam o racismo. Há sete décadas, a República não conhece movimentos racistas organizados ou expressões significativa de ódio racial. O preconceito de raça, acuado, refugiou-se em expressões oblíquas envergonhadas, temendo assomar à superfície. A condição subterrânea do preconceito é um atestado de que há algo de muito positivo na identidade nacional brasileira, não uma prova de nosso fracasso histórico.

"Quem exatamente é branco e quem é não-branco?" --a indagação do juiz Kennedy provoca algum espanto nos Estados Unidos, onde quase todos imaginam conhecer a identidade racial de cada um, mas parece óbvia aos ouvidos dos brasileiros. Entre nós, casamentos inter-raciais não são incomuns e a segregação residencial é um fenômeno basicamente ligado à renda, não à cor da pele. Os brasileiros tendem a borrar as fronteiras raciais, tanto na prática da mestiçagem quanto no imaginário da identidade, o que se verifica pelo substancial e progressivo incremento censitário dos pardos, que saltaram de $21 \%$ no 
Censo de 1940 para 43\% na PNAD de 2006, e pela paralela redução dos brancos (de 63\% para $49 \%$ ) ou pretos (de 15\% para $7 \%$ ).

A percepção da mestiçagem, que impregna profundamente os brasileiros, de certa forma reflete realidades comprovadas pelos estudos genéticos. Uma investigação já célebre sobre a ancestralidade de brasileiros classificados censitariamente como brancos, conduzida por Sérgio Pena e sua equipe da UFMG (Universidade Federal de Minas Gerais) comprovou cientificamente a extensão de nossas miscigenações. "Em resumo, estes estudos filogeográficos com brasileiros brancos revelaram que a imensa maioria das patrilinhagens é européia, enquanto a maioria das matrilinhagens (mais de 60\%) é ameríndia ou africana". Especificamente, a análise do DNA mitocondrial, que serve como marcador de ancestralidades maternas, mostrou que 33\% das linhagens eram de origem ameríndia, 28\% de origem africana e $39 \%$ de origem européia.

Os estudos de marcadores de DNA permitem concluir que, em 2000, existiam cerca de 28 milhões de afrodescendentes entre os 90,6 milhões de brasileiros que se declaravam brancos e que, entre os 76,4 milhões que se declaravam pardos ou pretos, 20\% não tinham ancestralidade africana. Não é preciso ir adiante para perceber que não é legítimo associar cores de pele a ancestralidades e que as operações de identificação de negros com descendentes de escravos e com afrodescendentes são meros exercícios da imaginação ideológica. Do mesmo modo, a investigação genética evidencia a violência intelectual praticada pela unificação dos grupos censitários pretos e pardos num suposto grupo racial negro.

Mas a violência não se circunscreve à esfera intelectual. As leis de cotas raciais são veículos de uma engenharia política de fabricação ou recriação de raças. Se, individualmente, elas produzem injustiças singulares, socialmente têm o poder de gerar raças oficiais, por meio da divisão dos jovens estudantes em duas raças polares. Como, no Brasil, não sabemos quem exatamente é negro e quem é não-negro, comissões de certificação racial estabelecidas pelas universidades se encarregam de traçar uma fronteira. A linha divisória só se consolida pela validação oficial da autodeclaração dos candidatos, num processo sinistro em que comissões universitárias investigam e deliberam sobre a "raça verdadeira" dos jovens a partir de exames de imagens fotográficas ou de entrevistas identitárias. No fim das contas, isso equivale ao cancelamento do princípio da autodeclaração e sua substituição pela atribuição oficial de identidades raciais.

Na UnB, uma comissão de certificação racial composta por professores e militantes do movimento negro chegou a separar dois irmãos gêmeos idênticos pela fronteira da raça. No Maranhão, produziram-se fenômenos semelhantes. Pelo Brasil afora, os mesmos candidatos foram certificados como negros em alguma universidade mas descartados como brancos em outra. A proliferação das leis de cotas raciais demanda a produção de uma classificação racial geral e uniforme. Esta é a lógica que conduziu o MEC a implantar declarações raciais nominais e obrigatórias no ato de matrícula de todos os alunos do ensino fundamental do país. O horizonte da trajetória de racialização promovida pelo Estado é o estabelecimento de um carimbo racial compulsório nos documentos de identidade de todos os brasileiros. A história está repleta de barbaridades inomináveis cometidas sobre a base de carimbos raciais oficialmente impostos. 
A propaganda cerrada em favor das cotas raciais assegura-nos que os estudantes universitários cotistas exibem desempenho similar ao dos demais. Os dados concernentes ao tema são esparsos, contraditórios e pouco confiáveis. Mas isso é essencialmente irrelevante, pois a crítica informada dos sistemas de cotas nunca afirmou que estudantes cotistas seriam incapazes de acompanhar os cursos superiores ou que sua presença provocaria queda na qualidade das universidades. As cotas raciais não são um distúrbio no ensino superior, mas a face mais visível de uma racialização oficial das relações sociais que ameaça a coesão nacional.

A crença na raça é o artigo de fé do racismo. A fabricação de raças oficiais e a distribuição seletiva de privilégios segundo rótulos de raça inocula na circulação sangüinea da sociedade o veneno do racismo, com seu cortejo de rancores e ódios. No Brasil, representaria uma revisão radical de nossa identidade nacional e a renúncia à utopia possível da universalização da cidadania efetiva.

Ao julgar as cotas raciais, o STF não estará deliberando sobre um método de ingresso nas universidades, mas sobre o significado da nação e a natureza da Constituição. Leis raciais não ameaçam uma elite branca, conforme esbravejam os racialistas, mas passam uma fronteira brutal no meio da maioria absoluta dos brasileiros. Essa linha divisória atravessaria as salas de aula das escolas públicas, os ônibus que conduzem as pessoas ao trabalho, as ruas e as casas dos bairros pobres. Neste início de terceiro milênio, um Estado racializado estaria dizendo aos cidadãos que a utopia da igualdade fracassou_e que, no seu lugar, o máximo que podemos almejar é uma trégua sempre provisória entre nações separadas pelo precipício intransponível das identidades raciais. É esse mesmo o futuro que queremos?

21 de abril de $2008 "$ 


\section{ANEXO 4 \\ “Manifesto em defesa da justiça e constitucionalidade das $\operatorname{cotas}^{375}$

\begin{abstract}
Documento entregue ao STF defende manutenção de cotas como um mecanismo de inclusão social e afirma que proposta contrária ao sistema é "caminho regressivo"
\end{abstract}

Veja a seguir trechos do documento que os defensores das politicas de cotas entregaram ontem ao ministro Gilmar Mendes, presidente do STF (Supremo Tribunal Federal). $O$ "Manifesto em Defesa da Justiça e Constitucionalidade das Cotas" sustenta que a política de ações afirmativas corrige desigualdades raciais históricas no país e argumenta que o grupo contrário não representa a comunidade negra.

Exmo sr. ministro:

"Aos 120 anos da declaração da abolição da escravatura, vivemos uma verdadeira efervescência na luta pela inclusão étnica e racial no ensino superior brasileiro: dezenas de universidades já implementaram sistemas de cotas, bônus ou outras modalidades de ações afirmativas, enquanto várias outras estão discutindo projetos similares. As avaliações realizadas até o momento mostram que, sem sombra de dúvida, apenas nos últimos cinco anos houve um indice de ingresso de estudantes negros no ensino superior maior do que jamais foi alcançado em todo o século 20. A caracterização desse avanço sem precedentes em nossa história como um privilégio de raça menospreza o fato de que as medidas responsáveis por esse cenário trouxeram um conjunto novo de oportunidades que estava vedada a milhões de pessoas que ocupam os extratos mais baixos de nossa sociedade.

No presente momento as iniciativas de inclusão racial e social no Brasil no campo do ensino superior contam com uma história rica e complexa, embora inconclusa, que certamente pode juntar-se ao repertório de outras notáveis conquistas ao redor do mundo. A demanda por políticas compensatórias específicas para os negros no Brasil não é recente e nem está baseada em qualquer modelo estrangeiro. Pelo contrário, insere-se na busca da justiça social em uma sociedade que historicamente se mostra racista, sexista, homofóbica e excludente. As cotas e o ProUni significam uma mudança e um compromisso ético do Estado brasileiro na superação de um histórico de exclusão que atinge de forma particular negros e pobres. Não são leis raciais, como dizem os 113 anticotas, mas um posicionamento do Estado coerente com os acordos internacionais de superação do racismo, de luta pelos direitos humanos dos quais o país é signatário. A primeira apresentação formal de uma proposta por ações afirmativas surgiu justamente na Convenção Nacional do Negro Brasileiro, realizada em 1945 e 1946, no Rio de Janeiro. Um

\footnotetext{
${ }^{375}$ Trechos do manifesto divulgados pelo jornal Folha de São Paulo, em 14/05/2008, p. C5 ,íntegra com os respectivos signatários no site http://media.folha.uol.com.br/cotidiano/2008/05/13/stf_manifesto_13_maio_2008.pdf, acesso em 10/09/2008.
} 
dos resultados desse evento foi o documento denominado "Manifesto à Nação Brasileira". As reivindicações ali apresentadas foram publicadas no primeiro número do jornal "Quilombo".

O que o "Manifesto à Nação Brasileira" propunha era uma ação afirmativa que se fundamentava na reparação dos danos causados pelo racismo da república brasileira, a qual havia decretado a igualdade formal sem oferecer nenhuma política concreta que ajudasse a superar a desigualdade fundante da condição sofrida pelos negros como cidadãos livres após 1889, que reconhecesse as terras dos quilombos e todas as formas de organização e produção (inclusive cultural e religiosa) que os escravizados constituíram em suas práticas.

Embora o excedente de seu trabalho tenha sido responsável pela construção do patrimônio do Estado brasileiro, e sua cultura tenha ajudado a constituir a sociedade, após a instauração da República a comunidade negra foi simplesmente abandonada. Recursos do Estado foram transferidos para a promoção de uma política imigratória baseada em critérios claramente raciais. Os negros resistiram às práticas de extermínio, e hoje encontram-se presentes em todas as instâncias da vida nacional.

Foram necessários mais de 50 anos para que o programa de promoção da população negra exposta no jornal "Quilombo" começasse a se transformar em política de Estado: o ProUni, iniciado em 2005, e também os sistemas de cotas nas universidades públicas, que oferecem bolsa para uma parcela dos egressos por esse sistema, são herdeiros diretos dessa proposta e de sua renovação prática por parte de um dos mais generosos movimentos brasileiros, aquele dos pré-vestibulares populares. Essas políticas formam a base sobre a qual o país pode se transformar em referência global extremamente positiva.

Entre as universidades, as primeiras a instituírem cotas para negros, em 2002, foram a Uerj (Universidade do Estado do Rio de Janeiro) e a Uenf (Universidade Estadual do Norte Fluminense), não por iniciativa própria, mas por meio de uma lei aprovada em 2001 na Assembléia Legislativa do Rio de Janeiro. Mais uma vez foi decisivo o trabalho do movimento negro, dos pré-vestibulares e outros setores, não apenas na proposição da lei, mas também com ações judiciais e participações em audiências públicas e debates que aconteceram nas duas universidades. Ainda em 2002, a Uneb (Universidade Estadual da Bahia) adotou cotas na graduação e na pós-graduação por decisão do seu conselho universitário.

A partir dai outras universidades passaram a adotar cotas. Começando então com uma meia dúzia de universidades com cotas em 2003, em 2007 já tínhamos mais de 50 instituições de ensino superior, entre universidades federais, estaduais, autarquias municipais e Cefets que estabeleceram alguma modalidade ou mecanismos de acesso que direcionavam uma porcentagem mínima de suas vagas a candidatos negros $e$ indígenas. Contrariando as irresponsáveis previsões apocalípticas sobre uma suposta guerra racial, ou a racialização de todos os aspectos da vida nacional, os projetos de ações afirmativas e outras formas de acesso da população negra ao ensino superior ganharam em legitimidade social.

O que esse quadro pressupõe é uma extraordinária mobilização e uma efervescência de debates ocorridos nos ambientes universitários em todas as regiões do país. Os projetos elaborados por estas instituições implicaram mobilização, pressão, articulação e produção intelectual de idéias, argumentos, modelos e proposições sobre como promover a igualdade 
étnica e racial no ensino superior, em uma intensidade sem paralelo em nenhuma década passada da história do Brasil.

Junto com os novos estudantes negros e indígenas que hoje ingressam nas universidades surgem novos temas de pesquisa, demandas por novos currículos e também demandas por mais professores negros e indigenas. Afinal, não somente os saberes africanos, afrobrasileiros e indigenas foram excluídos das nossas universidades que sempre reproduziram apenas os saberes europeus em uma relação neocolonial, mas o conjunto dos docentes e pesquisadores sempre tem sido majoritariamente branco.

A porcentagem média dos docentes das universidades públicas mais importantes do país raramente ultrapassa 1\%. Assim, o grande movimento pelas cotas, que por enquanto cresce como uma frente fragmentada e articulada de autônomos em cada campus de cada cidade e Estado do país conduz inevitavelmente a uma meta geral, já vislumbrada: que as medidas de inclusão de negros e índios possam ocorrer em todas as universidades públicas.

Atualmente, o país conta com mais de 20 mil cotistas negros cursando a graduação em universidades brasileiras de todas as regiões. Paralelamente a esse grande movimento de inclusão racial nas universidades públicas, funciona desde 2005 o ProUni, que abre as portas das universidades para jovens de baixa renda, com uma porcentagem, entre eles, de negros, através de um sistema de bolsas do Ministério da Educação. Em três anos, o ProUni já alocou 440 mil bolsas e conta com mais de 380 mil alunos. Se juntarmos os dois movimentos de abertura do ensino superior para brancos de baixa renda e para os não-brancos, as cotas nas universidades públicas e o ProUni em apenas cinco anos serão capazes de colocar quase meio milhão de estudantes negros que ingressarão no mercado ou na pós-graduação, levando consigo a esperança pessoal e familiar, num acontecimento de proporções monumentais, sem paralelo qualquer na história da sociedade brasileira.

\section{Os 113 anticotas}

A hipocrisia daqueles que pretenderam que o Brasil se transformasse do dia para a noite de último grande país escravocrata em exemplo mundial de harmonia racial e dos que hoje, na mesma linha, declaram que séculos de escravidão não deixaram nenhuma herança "racista" em nosso país se desenvolve a partir de uma série de falácias históricas, sociológicas e políticas. No plano histórico, escamoteia-se o duro e dramático trabalho e as lutas do movimento negro e outros movimentos anti-racistas para construir um novo e material horizonte de igualdade racial.

Enfim, no nível político, eles cometem uma tríplice impostura: 1) dizem que no Brasil apenas existe uma questão social, ou seja, ignoram a correlação sistemática que todos os estudos estatísticos indicam entre linhas de cor e curvas da pobreza, bem como que as cotas promovem também os outros segmentos de população discriminados pelo atual sistema de acesso ao ensino superior; 2) afirmam o mérito como único critério republicano, o que é duplamente falso: porque uma sociedade democrática sabe que o mérito deve ser um ponto de chegada e não um ponto de partida e é exatamente nessa medida que a democracia será 
sempre mais estável e mais próspera; porque toda politica de desenvolvimento do conhecimento implica em sistemas de cotas justamente destinadas a promover a excelência pelo subsídio a determinados segmentos de população; 3) reivindicam o pacto republicano, mas ignoram que tal pacto não é algo dado, mas um algo que precisamos construir para avançarmos nas conquistas democráticas. Neste ano fomos surpreendidos, em 28 de abril, com mais um manifesto intitulado "113 Cidadãos Anti-Racistas Contra as Cotas Raciais", entregue nesse Supremo Tribunal Federal em apoio à Ação de Inconstitucionalidade impetrada pela Confenen (Confederação Nacional dos Estabelecimentos de Ensino) pelo partido Democratas. Mas quem são, e a quem representam os 113 que exigem a expulsão de 440 mil estudantes negros e de baixa renda das universidades?

Apesar de se apresentarem como "intelectuais da sociedade civil, sindicalistas, empresários e ativistas dos movimentos negros e outros movimentos sociais", eles são basicamente acadêmicos: 80 deles são professores universitários e pesquisadores; desses 80, apenas um é negro. Representam, portanto, uma pequena parte da elite acadêmica branca centrada no eixo Rio de Janeiro-São Paulo que solicitam o retorno ao estado de exclusão do racismo institucional que imperava indiscriminadamente nas universidades brasileiras, $e$ a manutenção dos índices de presença da população negra que existia há 10 anos.

Que o patronato das escolas particulares, que lucram com os padrões de exclusão educacional existentes façam tal exigência, é perfeitamente compreensível. Que professores universitários, majoritariamente de instituições públicas de ensino superior, sindicalistas e ativistas do movimento negro partilhem exatamente esse mesmo projeto de aumento da desigualdade, é algo difícil de se justificar à opinião pública. No caso específico desses acadêmicos, há uma dimensão ético-política grave na sua postura. Por um lado, recebem verbas importantes para pesquisa das instituições públicas de fomento; e por outro, aliam-se as instituições privadas que nem sequer participam do esforço pela expansão e democratização do acesso ao ensino superior brasileiro. Outro ponto importante é que os 113 não incluem o segmento dos estudantes. Cometeram um lapso, de fato, porque há uma estudante entre os 113. Aqui fala o inconsciente político desse grupo.

Não resta dúvida de que esse grupo não representa a comunidade negra. As associações civis, culturais e religiosas negras, os vários setores do movimento negro, os pesquisadores, docentes e estudantes negros, todos em sua esmagadora maioria assinam o nosso manifesto.

\section{Martin Luther King}

Como no manifesto de 2006, os anticotas retomam agora o famoso discurso de Martin Luther King, "Eu Tive um Sonho". O que não dizem é que King sempre calçou o seu sonho universalista na necessidade de reparações e políticas compensatórias, inclusive de cotas. Três anos antes de pronunciar o discurso do sonho, King havia visitado a Índia a convite de Nehru, tendo oportunidade de conhecer de perto o sistema de cotas para os dalits (intocáveis). Lembremos inclusive que a política de cotas foi inventada na Índia. Em um texto na revista "Nation", em 1961, King relatou entusiasmado o modo com que o Estado indiano enfrentou a sua dívida histórica de racismo e discriminação pautando suas 
políticas "não somente pela igualdade, mas por tratamento especial de modo a permitir que as vítimas da discriminação saltassem do atraso à competência". E concluiu: "Quem dera nós aqui nos Estados Unidos tivéssemos alcançado esse nível de moralidade".

\section{Raça e inclusão}

A parte do documento dedicada à genética é particularmente confusa e inútil, além de contraditória para os seus próprios objetivos. Seu interesse é minar a realidade da diferença entre os seres humanos pelo fenótipo e demonstrar a mestiçagem genética que caracteriza a todos nós. Com isso, pretendem invalidar a possibilidade de que se adotem cotas para negros nas universidades ao "demonstrar" que "cientificamente" não existem negros. Para tanto, passam a afirmar que há negros com carga genética mais européia que africana obviamente, uma carga genética que não se revela na aparência física da pessoa.

E para que insistir em negar aquilo que ninguém afirma? A quem estão atacando? Não a nós, certamente, porque os defensores das cotas jamais falaram em raça no sentido biológico do termo. Somos nós que defendemos políticas públicas para a comunidade negra, que enfatizamos ser o racismo brasileiro o resultado histórico de uma discriminação dos brancos contra as pessoas de fenótipo africano.

\section{Contexto mundial}

O Alto Comissariado da Organização das Nações Unidas para a Eliminação do Racismo trabalha justamente nesta direção: a escravidão é considerada, como o Holocausto, um crime contra a humanidade imprescritível e por isso insta os países da diáspora africana nas Américas e no Caribe a desenvolver políticas de ações afirmativas para os descendentes de africanos escravizados.

Prestar conta do seu passado racista, colonialista e genocida diante dos escravizados e dos povos indígenas originários é uma discussão política que atravessa os cinco continentes, e esses 113 querem calar essa discussão no Brasil.

Como plataforma internacional, o "Manifesto dos 113" isola o Brasil das forças progressistas do mundo, como os manifestos escravocratas isolaram o país no século 19. A maior vergonha de sua posição é negar que a condição de branco signifique vantagem na vida brasileira.

O "Manifesto dos 113" termina com uma visão catastrófica das relações raciais que mais parece um desejo dos assinantes, tal seu deslocamento da realidade: "Leis raciais não ameaçam uma "elite branca"", conforme esbravejam os racialistas, mas passam uma fronteira brutal no meio da maioria absoluta dos brasileiros. Estamos aqui, nos limites do delírio. UnB, Uerj, Uenf, UFPR, Ufal, Uneb, todas têm cotas para negros há 5 anos e não há indícios de que essa linha divisória tenha se instalado. Essa retórica da catástrofe é exatamente a mesma que circulava no Brasil republicano na última década da escravidão quando crescia o movimento abolicionista. 


\section{Doutrina}

A Constituição, com base no pluralismo, marca um significativo avanço para a efetividade dos direitos dos brasileiros pertencentes a grupos tradicionalmente excluidos. Por diversos de seus dispositivos, rompe com o mito da democracia racial, assegurando o direito à diferença, ao reconhecer e valorizar as especificidades étnico-raciais, sociais, religiosas e culturais dos povos que compõem o Brasil.

Atentemos ao que diz a doutrina mais abalizada: "A definição jurídica objetiva e racional da desigualdade dos desiguais, histórica e culturalmente discriminados, é concebida como uma forma para se promover a igualdade daqueles que foram e são marginalizados por preconceitos encravados na cultura dominante (...). A ação afirmativa é, então, uma forma jurídica para se superar o isolamento ou a diminuição social a que se acham sujeitas as minorias" (Carmem Lúcia Antunes Rocha, Ação Afirmativa - O Conteúdo Democrático do Princípio da Igualdade Jurídica, in Revista Trimestral de Direito Público. $n^{o}$ 15:18). No mesmo sentido: "Atualmente, as ações afirmativas podem ser definidas como um conjunto de políticas públicas e privadas de caráter compulsório, facultativo ou voluntário, concebidas com vistas ao combate à discriminação racial, de gênero e de origem nacional, bem como para corrigir os efeitos presentes da discriminação praticada no passado, tendo por objetivo a concretização do ideal de efetiva igualdade de acesso a bens fundamentais como a educação e o emprego" (Gomes, Joaquim Barbosa. In: Ação Afirmativa \& Princípio Constitucional da Igualdade. Rio de Janeiro: Renovar, 2001). Por derradeiro temos ainda: "Não basta não discriminar. É preciso viabilizar e encontrar, na Carta da República, base para fazê-lo as mesmas oportunidades. Há de ter-se como página virada o sistema simplesmente principiológico. A postura deve ser, acima de tudo, afirmativa. E é necessário que essa seja a posição adotada pelos nossos legisladores. [...]. A neutralidade estatal mostrou-se nesses anos um grande fracasso; é necessário fomentar-se o acesso à educação [...]. Deve-se reafirmar: toda e qualquer lei que tenha por objetivo a concretude da Constituição Federal não pode ser acusada de inconstitucionalidade" (Cf. Mello, Marco Aurélio. Óptica Constitucional - A Igualdade e as Ações Afirmativas. In: Revista latino americana de Estudos Constitucionais, v. 01, Belo Horizonte Del Rey, 2003, p 11-20). na esfera normativa, desde que haja equivalência e equilíbrio entre a norma e seus fins.

Essas ações, que são erigidas pelo próprio sistema normativo, para se tornarem legítimas, devem estar revestidas na proporcionalidade. Nesse cenário, elementos como sexo, raça, credo religioso, dentre outros, podem servir de base ao discrímen na esfera normativa, desde que haja equivalência $e$ equilíbrio entre a norma $e$ seus fins. Por isso, o legislador, ao criar as políticas de cotas, buscou dar efetividade aos objetivos estabelecidos na Constituição, consagrando o conteúdo jurídico, democrático e também afirmativo da igualdade.

Em relação ao princípio do mérito, as universidades que adotaram cotas buscam levar em consideração a história dos atores envolvidos na corrida imposta pelo vestibular. Os estudantes promovidos pelas políticas de inclusão precisam alcançar os padrões objetivos de 
avaliação estabelecidos pelas universidades. Nesse sentido é que as cotas estão em perfeita sintonia com o mérito descrito na Constituição.

Também devemos ressaltar a importância do pioneirismo desta Corte ao adotar administrativamente as políticas de cotas raciais por meio da concorrência para contratação de profissionais de serviços de jornalismo -3/2001, pela qual 20\% das vagas eram para os negros.

Por esses fundamentos, entendemos que as cotas são constitucionais, pois se afirmam numa postura capaz de realizar política e juridicamente o princípio do pluralismo. A luta pela igualdade racial e a justiça inclusiva no Brasil iniciou-se no mesmo dia 13 de maio de 1888. Encontramo-nos atualmente em um momento de encruzilhada dessa luta: por um lado, é lícito dizer que estamos no melhor ano já vivido pela comunidade universitária afro-brasileira. Com todo o racismo e toda a exclusão hoje no ensino superior, temos mais jovens negros e de baixa renda nas nossas universidades neste semestre de 2008 do que tínhamos em 2007 e assim retrospectivamente.

Acreditamos ter apresentado argumentos sólidos em favor da justiça e da constitucionalidade das políticas reparatórias de inclusão atualmente em curso. Mostramos igualmente a fragilidade e a imprecisão dos argumentos da pequena elite acadêmica branca que ainda reage a um processo histórico de proporções grandiosas. Sobre os 113 reacionários ao ProUni e às cotas, queremos enfatizar o seguinte: nada têm a propor a não ser adiar para um futuro incerto quem sabe para daqui a 120 anos a possibilidade de uma igualdade de oportunidades entre negros, brancos e indígenas no Brasil. Literalmente, o caminho por eles apontado é um caminho regressivo.

A perspectiva, portanto, é de avançar cada vez mais na direção de um ano acadêmico em que a proporção de estudantes negros nas nossas universidades públicas seja equivalente à da sua porcentagem da população brasileira como um todo. Esperar e lutar por essa equanimidade de acesso para negros, brancos e indígenas no ensino superior não é nada mais que esperar por justiça social e racial.

\section{Conclusão}

Esse é o quadro, senhores ministros, que temos diante de nós. Está nas mãos de Vossas Excelências não apenas o destino das centenas de milhares de estudantes que, graças às políticas de inclusão, conseguiram o sonhado ingresso na universidade. Está nas mãos de Vossas Excelências a decisão que possibilitará ou não a continuidade das medidas que fizeram este país começar a ajustar contas com seu passado escravista e seu presente discriminatório, rumo a um futuro sem injustiças e concretamente democrático. Para as vossas mãos se voltam os olhos de milhões de brasileiros cheios de esperança num Brasil mais justo, mais solidário, que, com base nos princípios constitucionais, se afirma materialmente contra desigualdades incompatíveis com o Estado Democrático de Direito. Uma vez superada essa reação ressentida dos que se opõem à inclusão racial e à justiça social, crescerá a esperança e se intensificará ainda mais o presente movimento de consolidação definitiva da igualdade socioeconômica e étnico-racial no Brasil." 